\title{
PRIORITY TASKS AND STRATEGIES FOR THE DEVELOPMENT OF JURISPRUDENCE
}

Collective monograph

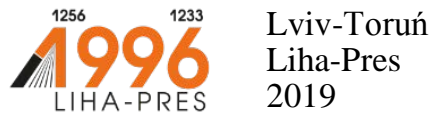




\section{Reviewers:}

Prof. dr hab. Sabina Grabowska, Uniwersytet Rzeszowski / University of Rzeszow (Republic of Poland);

Prof. dr hab. Joanna Marszatek-Kawa, Uniwersytet Mikołaja Kopernika w Toruniu / Nicolaus Copernicus University (Republic of Poland).

Priority tasks and strategies for the development of jurisprudence : collective monograph / D. M. Bielov, M. Yu. Vikhliaev, M. V. Hromovchuk, O. Ya. Rohach, etc. - Lviv-Toruń : Liha-Pres, 2019. - 212 p.

ISBN 978-966-397-153-7

Liha-Pres is an international publishing house which belongs to the category „C” according to the classification of Research School for Socio-Economic and Natural Sciences of the Environment (SENSE) [isn: 3943, 1705, 1704, 1703, 1702, 1701; prefixMetCode: 978966397]. Official website - www.sense.nl. 


\section{CONTENTS}

FEATURES CORRELATION CONSTITUTION AND STATE POLICY

Bielov D. M., Vikhliaev M. Yu.

HUMAN RIGHTS FOR LIFE: EXPERIENCE OF UKRAINE

Hromovchuk M. V., Rohach O. Ya. 18

REGULATION OF FREEDOM OF ACCESS

TO ENVIRONMENTAL INFORMATION IN THE LEGISLATION

OF THE EUROPEAN UNION AND UKRAINE

Kachuriner V. L.

WAYS OF PUBLIC-LAW DISPUTE RESOLUTION

Kivalov S. V.

THE GENESIS OF LOCAL SELF-GOVERNMENT

IN UKRAINE. URGENT ISSUES OF LEGAL SUPPORT

OF LOCAL SELF-GOVERNMENT

Panchyshyn R. I.

CONCEPT AND BASIC FEATURES OF THE ADMINISTRATIVE

ACTIVITIY OF THE REVENUE AND DUTYAUTHORITIES

EXECUTING CUSTOMS AFFAIRS

Pryimachenko D. V .86

HUMAN RIGHTS BALANCES IN HEALTHCARE FIELD

UNDER THE JURISPRUDENCE OF THE EUROPEAN COURT

OF HUMAN RIGHTS

Senyuta I. Ya.

RECEPTION OF THE INSTITUTES OF THE CONSTITUTIONAL MECHANISM FOR THE PROTECTION OF HUMAN RIGHTS IN UKRAINE

Verlos N. V. 
SOCIAL DIALOGUE IN THE FIELD OF LABOUR:

DEFINITION AND LEGAL REGULATION

Chanysheva G. I.

INTERACTION OF THE UKRAINE NATIONAL POLICE

WITH OTHER SUBJECTS OF PUBLIC SECURITY

IN THE CONDITIONS OF THE UNITED FORCES OPERATIONS

Abroskin V. V. 164

IMPROVEMENT OF ADMINISTRATIVE AND LEGAL

BASIS OF INSTITUTION OF JUSTICE OF UKRAINE

Predmestnikov O. H. 184 


\section{FEATURES CORRELATION CONSTITUTION AND STATE POLICY}

\section{Bielov D. M., Vikhliaev M. Yu.}

\section{INTRODUCTION}

Constitutionalism as a politico-legal category and doctrinal learning appears after the emergence and establishment of the constitution of the state in the modern sense of this term. It is inseparable and directly derived from the constitution of the state. Although not always the fact of the existence of a constitution automatically means the emergence of a particular model of constitutionalism. However, without the appearance (availability) of the constitution itself (in the broad sense of this notion), there is no need to talk about constitutionalism. The substantive basis, the very essence of constitutionalism, according to V. Shapoval, is expressed by the formula: "constitutional-legal norm + practice of its implementation", Therefore, a bit strange, in our opinion, when in certain writings, including monographs, there are such statements as "ancient”, "medieval”, "totalitarian" or "Soviet constitutionalism", since at that time the constitution as such (in the modern understanding of this concept) simply did not exist. However, it was precisely in previous times that, in fact, the foundations of the future phenomenon - constitutionalism were laid ${ }^{2}$.

The Constitution of Ukraine is a part of the national legal system, its core, acts as "coordinator of the system of legislation" 3 . But, as $\mathrm{Yu}$. Tykhomyrov notes, despite the fact that the Constitution, as if is in the middle of the legal array, its influence is not limited to the link "act-act". All elements of the legal system, in turn, also affect the constitution ${ }^{4}$.

On the one hand, the Constitution is a kind of construction, on which practically all legislation is being built ${ }^{5}$. It is the Constitution that defines the nature of the current legislation, the process of law-making - determines,

${ }^{1}$ В.М. Шаповал. Конституиійне право зарубіжних крайн: Підручник, АртЕк, Вища шк., Київ 1997, р. 135.

${ }^{2}$ П.Б. Стецюк. Основи теорії конституиії та конституціоналізму. Частина перша: Посібник для студентів, Астролябія, Львів 2004, р. 98.

${ }^{3}$ И.М. Степанов. Конституция и политика, Изд-во Наука, Москва 1984, р. 40.

${ }^{4}$ Ю.А.Тихомиров. И.В. Котелевская, Правовые акты. Учебно-практическое и справочное пособие, Юринформцентр, Москва 1999, р. 15.

${ }^{5}$ О.В. Оніщенко. Конституція України як основне джерело конституційного права України. Вид.: Консум, Київ 2005, р. 211. 
which basic acts are adopted by various bodies, their names, legal force, the process and procedure for the adoption of laws ${ }^{6}$. The development of legislation is possible only within the parameters enshrined in the Constitution, which serves as an important condition for ensuring its unity, internal coherence ${ }^{7}$. As S. Shevchuk notes, the constitutional norms are formulated in the form of an open text, and, consequently, constitute "empty vessels", which must be filled with a specific content ${ }^{8}$. Therefore, the adoption of a new constitution in the state, as a rule, causes significant changes and updates to current legislation. Ukraine is no exception. Although, as V. Opryshko notes, "the current legislation does not yet fit into the legal framework defined by the Constitution of Ukraine" " .

However, the notion of a constitution cannot be disclosed to the full extent without clarifying the question about not only its legal but also socio-political nature.

\section{Constitution and state policy: common questions}

Today, one of the reasons for the constant tension in relations between the supreme bodies of state power in Ukraine is the imperfection of the Basic Law, the different interpretation of its norms, as well as the fundamental change of the state policy, especially after the 2004-2005 presidential elections.

The constitution has a mixed political and legal nature, as well as to a large extent all constitutional law. Constitutional relations that arise on the basis of its provisions can also be characterized as having a dual nature: political and legal at the same time. Powerful relations subject to constitutional regulation create prerequisites for the appearance of political issues in constitutional law and politicize it to a certain extent. The political and legal in the constitution are closely intertwined, as well as the implementation of constitutional provisions can have a legal and political dimension.

As A. Heywood has rightly pointed out, for the vast majority of democratic states, constitutions were traditionally perceived as "precise descriptions of the current system of government"10. Consequently, any

${ }^{6}$ Е.И. Козлова, О.Е. Кутафин. Конституционное право России. Юристъ, Москва 2003, p. 87.

7 В.О. Лучин. Конституция Российской Федерации. Проблемы реализации, ЮнитиДана, Москва 2002, р. 79.

${ }^{8}$ С. Шевчук. Основи конституціийної юриспруденщії: Навч.посібник, Консум, Харків 2002, p. 7.

${ }_{9}^{9}$ В.Ф. Опришко. Конституиія України - основа системи національного законодавства. Видавничий Дім «Юридична книга», Київ, 2000, р. 118.

10 Э. Хейвуд. Политология. Юнити-Дана, Москва 2005, р. 359. 
constitution always carries a certain prognostic-axiological element, which allows foreseeing a further direction of the state development and, accordingly, state policy. It is important to note that the prognostic function of the Constitution is directly written by well-known domestic researcher Yu. Todyka ${ }^{11}$. However, we now mean not only one of the possible functions of the constitution but also the fact that at its level the values are laid down that the state is called to provide.

The authors of the monograph "Politics, Law and Power in the Context of Transformation Processes in Ukraine" characterize state policy as a "system of purposeful measures aimed at solving certain social problems, meeting public interests, ensuring the stability of the constitutional, economic, legal system of the country [...] the specificity of which is that it is realized through the power structures that have the authority of the monopoly right of the state to lawful coercion"12. Indeed, the link between the state policy and the constitution is shown by not only the reference to such a concept as "constitutional system". From the outset, the authors of the above-mentioned study establish a clear correlation between the direction of state policy and the process of ensuring social stability and satisfaction of the public interest. It should be borne in mind: the main social interests are always connected with the system of rights and freedoms of citizens of the state, which are not only formally fixed in the Constitution but must also be secured by it as a legal act of the highest legal force, which has a sign of direct imperative action (Article 8 of the Constitution of Ukraine) $)^{13}$.

The same can be said for a widely used in the modern Ukrainian science definition of the state policy by V. Tertychka. This author proposes to interpret the state policy in the following way: "relatively stable, organized, and purposeful activity/inactivity of state institutions, carried out by them directly or indirectly on a particular problem or a set of problems that affects the life of society"14. Moreover, justifying the appropriateness of this way of understanding the phenomenon of state policy, he notes that the definition of state policy implicitly implies that it is based on the law and must be legitimate. That is, state policy does not appear, so to speak, solely on its own accord and on their own will of those who are currently endowed with state power. On the contrary, in order that this direction of the state's activity

${ }^{11}$ Ю.Н. Тодыка. Конститучия Украины, рр. 70-80.

12 Політика, право і влада в контексті трансформаційних процесів в Украйні. Еd. I.О. Кресіної. Інститут держави і права ім. В.М. Корецького НАН України, Київ 2006, р. 35.

${ }^{13}$ І. Гладуняк. Конституція, рр. 11-12.

${ }^{14}$ Політика, право і влада в контексті трансформаційних процесів в Україні, pp. 82-83. 
should be systematic and coherent, it is necessary from the very beginning to have a certain set of rules and principles that would indicate: a) the type of political regime; b) the way of organizing state power; c) the main political institutions, the presence of which ensures the normal development of the state mechanism; d) the basic values and tasks that must be implemented during state and social development.

These rules should be fixed at the legislative level so that there are no ambiguous political interpretations of the way, in which policy should be implemented and on what grounds ${ }^{15}$. The universal method of fixing these rules and regulations is the method of constitutional determination. By giving these rules and principles an imperative value, the state acts as the guarantor of the fact that all participants in social and political relations will adhere to them. At the same time, it itself, as a mechanism of institutionalized coercion, will act in accordance with certain standards. Therefore, it is quite natural that in all democratically-operated countries, programs for the realization of state policy are always developed and implemented in accordance with the constitution.

However, it is necessary to distinguish between the constitution as a legal act and the functions specific to it in the legal field and the constitution as a political document having a certain socio-political content that directly or indirectly affects the entire political system of the country ${ }^{16}$.

Consequently, the relationship between the constitution and politics manifests itself in two main areas. First, in a broad sense, political relations are one of the most important constituent parts of constitutional regulation. Constitutional norms set legal boundaries for the political process. They consolidate the foundations of the political system of society, and not only. In modern constitutions, the foundations of the social and spiritual systems of society, which affects the expansion of the object of constitutional regulation at the turn of XX - XXI centuries, are increasingly reflected. As rightly $\mathrm{V}$. Chyrkin notes, "constitutional law went beyond a largely formalized approach of the XVIII - XIX centuries and spread to the settlement of issues of the social system, the situation of one or another stratum, groups of the population (social, national, age, etc.), socio-economic rights"17.

Secondly, the constitution itself embodies a certain policy of the state, the desire of the project developers to consolidate certain principles and

${ }^{15}$ І. Гладуняк. Конституичія, рр. 11-12.

${ }^{16}$ Ibidem.

17 Б.Е. Чиркин. Об объекте конституционно-правового регулирования. Российский консти-туционализм: проблемь и решения: материаль международной конферениии, Академия, Москва 1999, р. 126. 
political values. Even K. Marx argued that "all legal has in its essence a political nature" ${ }^{18}$. This thesis on the Basic Law, according to V. Luchyn, becomes of a special significance. The political orientation of the constitution is one of the most important qualities that determine its special role in the legal system, a special social role in society. However, the idea that a constitution is created by the state to achieve a certain political goal requires some adjustments ${ }^{19}$.

From the standpoint of democratic constitutionalism and the theory of social contract, both the institutions of public authority and the electoral body participate in the act of constitution creation in one way or another. Therefore, official representatives of the state - only one of the subjects of the constitution creation. The constitution should integrate not only state goals of development but also the idea of society about the goals of social progress, to be an indicator of the needs of different social groups, the expression of their expectations and hopes ${ }^{20}$.

In the history of Ukrainian constitutionalism, the Constitution has repeatedly acted as a tool of state policy, ruling circles or political forces that came to power. Thus, the First Soviet Constitution - the Constitution of the RSFSR of 1918 - consolidated the victory of the proletariat and the poorest peasantry after the October Revolution, and was actively used by the Bolsheviks as a means of political struggle against social strata and classes that did not share the ideals of socialist construction.

Interesting is the characteristic of the Constitution of the RSFSR of 1918, given by the well-known Soviet legal ideologist of the 20's P. Stuchka to the twelfth anniversary of the revolution of the state and law. He called it "the civil war constitution", which is largely justified since it openly supported class positions on the issue of the acquisition and implementation of basic civil and political rights and freedoms ${ }^{21}$. Later in the process of constitutional development of the Soviet state, constitutional right gradually cleared itself from the ability to act as a tool of class domination, acquiring the nature of a universal legal regulator ${ }^{22}$.

In the mid-80's, political scientist I. Stepanov, reflecting on the relationship between the constitution and politics, expressed the view that politics and law should be represented in the constitution in an organically

${ }^{18}$ К. Маркс, Ф. Энгельс. Сочинения, 2-е изд. vol. I, Политиздат, Москва 1991, p. 635.

${ }_{19}$ В.О. Лучин. Конституционные нормы и правоотночения: учебное пособие [для вузов], Эксмо, Москва 1997, pp. 33-34.

${ }^{20}$ І. Гладуняк. Конституція, рр. 11-12.

${ }^{21}$ П.И. Стучка. Двенадцать лет револющии государства и права, “Революция права” 6 (1929), p. 10.

${ }^{22}$ І. Гладуняк. Конститучиiя, рр. 11-12. 
integral form, "balanced in a coherent unity"23. Of course, during the Soviet period, the study of the constitutional policy was limited by many partyideological barriers. However, the search for an optimal combination of politics and law in the constitution, constitutional policy, and political law is an important and constantly restored process of democratic development.

On the one hand, the tradition of observing constitutional limitations by subjects of political activity and political relations should be developed. On the other hand, the constitutional law should not be disconnected from political issues, and constitutionalists should seek to see political aspects in the implementation of constitutional norms. The study of political issues in constitutional law can shed light on the motives for adopting the constitution as a whole or individual constitutional changes, it can serve as an explanation or justification for the constitutionally regulated actions of state bodies and officials. In general, political issues highlight the controversial and problem areas of constitutional and legal development, contribute to the formation of a constitutional paradigm within the legally established normative framework of relations of person, society, and state ${ }^{24}$.

In the concept of a political constitution, a special vision of a political community is laid down, in which a coordinated interaction between citizens and authorities is ensured and a political agreement on rules of conduct in the political sphere is taking place. History gives a lot of examples of violent imposing of the constitution by the ruling party, the authoritarian head of state, the oligarchic or military regime. However, in the spirit of the democratic policy, a constitution as a political document cannot be a political pact, which reflects the search for public consent and compromise in resolving various political and social conflicts ${ }^{25}$.

In the political sphere, functions of the constitution are inextricably linked with its nature. In many respects, its effectiveness in the field of politics depends on the nature of the constitution. After all, the nature of the constitution is its socio-political content. In the national political science, in the Soviet era, the class nature of the constitution and its content were distinguished. Under class nature, they understood the basic socio-political characteristics of the constitution. It finds its manifestation in its content, principles, properties, and functions, has a decisive influence on its form, defining its fundamental features. The content of the

${ }^{23}$ И.М. Степанов. Конституциия и политика, р. 24.

${ }^{24}$ И.А. Кравец. Сущฺность конституций и конституционный процесс (динамика сочиально-политического содержания российских конституций). «Весник Московского» гос. ун-та. 4 (2003), р. 35.

${ }^{25}$ І. Гладуняк. Конституичія, pp. 11-12. 
constitution is the specification of its class nature. Moreover, the content may vary within a specific nature under the influence of a number of objective and subjective factors. The constitution had a dual meaning social and legal ${ }^{26}$. The point is that this approach was based on a formative theory, according to which the specifics of the nature of the constitution in different countries were tied to a certain socio-economic formation. Throughout the period of the development of Soviet constitutions, even in the late period, known as "developed socialism", dominated the class concept of the nature of the constitution, which was determined by the class (classes) it serves and which type of property it establishes ${ }^{27}$.

In our opinion, the nature of the constitution derives from its sociopolitical content, so to speak, in a concentrated form. The legal content of the constitution is determined by the objects of constitutional regulation, in other words, what legal institutes, principles, and provisions are reflected in the text of the constitution and in this regard acquire the constitutional status. Given the differences in the legal and socio-political content of the constitution, it is necessary to identify the key elements of its nature, which have a political influence on the functioning of constitutional provisions.

These elements can be formulated in the form of theoretical postulates, the answers to which give a general idea of the nature of a specific constitution. These include:

1) the will of which political forces found a consolidation in constitutional provisions (whose political will was enshrined in the constitution?);

2) the interests of which social strata are reflected in the constitutional provisions and supported by them (whose interests are reflected and supported by the constitution?);

3) what is the degree of legitimacy of the constitution, which is largely determined by the terms of its project development and the procedure for its adoption (how the chosen procedure for the development and adoption of the constitution influenced the degree of its legitimacy?).

In specific historical conditions and the legal culture of an individual country, the answers to these questions may vary. In the constitutional history of one and the same country, different constitutions may have a

${ }^{26}$ Ю.Л. Юдин. Конституцчии, in: Конституционное право развивающчихся стран: предмет, наука, источники, еd. В.Е. Чиркин. Юридическая литература. Москва 1987, р. 39.

${ }_{27}$ Н.П. Фарберов. Новая Конституция СССР - манифест эпохи строительства коммунизма, in: Н.П. Фарберов. Конституциия развитого социализма. Восход-А, Москва 1979, p. 68. 
different essence. Moreover, the essence of one and the same constitution can eventually be transformed and move away from the original idea of its creators. This is primarily related to the fact that the socio-political conditions of the constitution, the implementation of its provisions can change.

\section{Modern approaches to understanding the nature of the constitution}

In modern constitutionalism, there are three basic approaches to understanding the nature of the constitution: liberal-democratic, Marxist-Leninist, and theological. These three directions in constitutional law indicate differently the main purpose of the constitution in the political sphere.

The liberal-democratic approach was formed at the end of the XVIII century, although it relied on the ideas and values of the English and French educators, which were developed in the works of J. Locke, Ch. Montesquieu, J. Russo and others within the school of natural law.

At the heart of a liberal-democratic approach lies the doctrine of the social contract. According to it, the constitution is considered as the result of public consent, a compromise between different social strata and political forces on the fundamental principles of organization of society and state, the relationship between individuals and the state. The constitution as a social contract is an important indicator of the political consensus existing in society.

In countries where the constitution has long operated in a high political consensus, it becomes the nature of an agreement, to which each subsequent generation may add new provisions or change existing ones. According to the recognition of American constitutionalists N. Redlich, B. Schwartz, and J. Attanasio, in "American law, a word "constitution" has a more limited meaning; it is a written agreement transmitted from the first generation of Americans to future generations”28 . Another American researcher J. Reiman argues that the foundations of American constitutional democracy are human rights and a social contract, and considers the constitution from three sides: as a written text, as a social practice, and as a moral promise ${ }^{29}$.

The Marxist-Leninist approach was developed in the second half of the XIX - the beginning of the XX century. As a theoretical concept, it was formed on the ideas and views expressed by the classics of Marxism (K. Marx and F. Engels) and substantially complemented by the leader of

\footnotetext{
${ }^{28}$ N. Redlich, B. Schwartz, J. Attanasio, Understanding Constitutional Law, Matthew Bender, Irwin 1995, p. 21.

${ }^{29}$ J. Reiman. The Constitution, Rights, the Conditions of Legitimacy, in: Constitutionalism: The Philosophical Dimension, ed. A.S. Rosenbaum, Greenwood Press, New York 1988, p. 133.
} 
the Bolsheviks V. Lenin. It sought to adapt the postulates of classical Marxism to the socio-political realities of early XX century. K. Marx and F. Engels noted that the constitution, as a result of the class struggle, is established by the ruling class, the class that won. In their opinion, after the seizure of power, the ruling classes must constitution their power not only in the form of state but also "to give their will ... a general expression in the form of state will, in the form of law" ${ }^{30}$. And such a law, above all, is a constitution. Stressing the class nature of the constitution, V. Lenin wrote: "The nature of the constitution is that the basic laws of the state in general and the laws concerning the electoral law to representative institutions, their competence, etc., express the true balance of forces in the class struggle" 31 .

The practical implementation of this approach was first introduced during the creation of the first Soviet Constitution of the RSFSR in 1918, and then became widely used in socialist states, where a special type of constitution and one or another type of Soviet form of government were established. The representatives of this approach saw in the constitution not the result of the agreement but the outcome of the class struggle, which was recognized as the dominant engine of historical progress. A class approach to understanding the nature of the constitution denied the right to a political compromise. The constitution always manifests the will of the economically dominant class, which has won a political victory over other classes and smaller social groups. Therefore, the constitution may reflect interests of only the winner of the political struggle, a class that has occupied economic heights, that is, such a class should also possess means of production ${ }^{32}$.

The theological approach is a definite combination of ideas of secular and divine law. It appeared much later than other approaches as a result of distribution in the XX century (mainly in its second half) of constitutional ideas and principles in the countries of the Arab East, where the sources of Muslim law occupy a dominant position. The notion of a constitution in these countries is associated with the provision of divine rules of conduct for a "religious community". If a constitution exists as a written act, it should not contradict the most important source of Muslim law - the Quran. Political struggle is not encouraged, if not forbidden, and

${ }^{30}$ К. Маркс, Ф. Энгельс. Сочинения, р. 122.

${ }^{31}$ В.И. Ленин. Полное собрание сочинений. Vol. XXXVI, Политиздат, Москва 1980, p. 535.

32 Д.М. Бєлов. Структура та зміст конституиії: окремі аспекти, «Науковий вісник Ужгородського національного університету. Серія Право»,14 (1) 2010, р. 85. 
consent is achieved through faithfulness to the confession of a single religion of Islam.

The norms and principles of Muslim law have a profound impact on the constitutional legislation and the form of government in countries such as Iran and Saudi Arabia. Muslim law also plays a leading role in these countries in other areas of current law, which is confirmed at the constitutional level. For example, the Iranian Constitution establishes the provisions on the mandatory compliance of all laws that are adopted with the Sharia law ${ }^{33}$. Moreover, the Sharia regulations are transformed into legal constructs, which are used in the theory and practice. Thus, the three requirements of the Quran, which obliged to consult in making important decisions, to handle all cases in all fairness, and obey the ruler, were the basis of the theory of "Islamic rule" developed by Muslim legal scientists in detail - theories of the organization and activities of the state ${ }^{34}$.

The constitution in these countries legitimises "Islamic rule" as a special form of theocratic state ${ }^{35}$. By revealing the content of the Islamic Republic, the Iranian Constitution states that it is based on the belief in Allah and its comprehensive power, "divine revelation" that determines any laws, as well as in the belief in the responsibility of man to Allah (Article 2). With the role of Islam, as the most important political and ideological basis of the state, the relation to it as one of the legitimizing factors ensuring the stability of the ruling regime is connected. Therefore, it is not a constitution that acts as a measure of "legitimacy" of the existing regime but the Islamic values that arise from Sharia and are firmly rooted in the mass consciousness.

Interesting, in our opinion, is the approach of Hungarian constitutionalist A. Sajó. Rejecting traditional views on the nature of the emergence of constitutions (an ideal program of reconstruction of society, ensuring stability, rational state structure), he formulates a paradoxical thesis: constitutions arise under the influence of fear. Like a psychoanalyst who studies human experiences during the formation of his biography, he sees a direct motive for the adoption of constitutions in the dominant fears of authors of constitutions ${ }^{36}$.

33 Л.Р. Сюкияйнен. Мусульманское право: вопросы теории и практики. Наука, Москва 1986, p. 102.

${ }^{34}$ Idem. Шариат и мусульманско-правовая культура, Армада, Москва 1997, pp. 14-15.

${ }^{35}$ Е.Н. Салыгин. Теократическое государство. Юридическая литература, Москва 1999, p. 45.

${ }^{36}$ A. Sajó. Limiting Government. An Introduction to Constitutionalism, Central European University Press, Budapest 1999, p. 311. 
Thus, the founding fathers of the US Constitution in 1787 acted under the influence of a paranoid desire to avoid the establishment of a monarchy or popular democracy; an example of the ineffectiveness of the Weimar Constitution and the establishment of the Nazi regime hung over the authors of the German Constitution of 1949; the Constitution of France of De Gaulle of 1958 sought to prevent the repetition of parliamentary paralysis of the Fourth Republic.

The constitutions adopted during the democratic revolutions in the countries of Eastern Europe (Hungary, Slovakia, Czech Republic, Bulgaria), sought to overcome the preliminary system of power concentration in the hands of one person. Emphasizing the principle of national sovereignty, they put forward an idea of a strong unicameral parliament, which inevitably leads to the consolidation of government ${ }^{37}$.

\section{The legal nature of the constitution of Ukraine}

In the Ukrainian society, which is at the stage of modernization of its political, legal, and economic systems, the attitude to the Constitution is a private aspect of the social outlook split by the differentiation of social strata. This attitude reflects the process of a new stratification of the changing society. Constitutional development of Ukraine in the XX century was accompanied by several fundamental changes in the civilizational foundations of the existence of society and the state. Existing constitutions reflected in a different way the balance of political forces and had unequal socio-political content ${ }^{38}$.

The Constitution of 1919 reflected and embodied the political development of revolutionary authoritarianism. Its essence lies in the fact that, in general, it is based on a broad democratic basis, in contrast to the census monarchical constitutions of the XIX - the beginning of the XX century. The logic of revolutionary authoritarianism came from the principle of Salus populi suprema lex est (from Latin "The good of the people should be the supreme law").

The constitution consolidated the new political reality of the union of workers and peasants for the growth of the people's good. V. Lenin stressed that the Soviet constitution is not invented by any commission, not written off from other constitutions, not drawn up in the offices, but developed on the basis of the experience of the struggle of the working people and the organization of proletarian masses ${ }^{39}$. However, the concern for the people's

\footnotetext{
${ }^{37}$ Ibidem. P. 312.

38 Д.М. Бєлов. Структура та зміст конституиії, р. 86.

${ }^{39}$ В.И. Ленин., Полное собрание сочинений, р. 45.
} 
good was given to the revolutionary avant-garde - the Communist Party, whose representatives, combining party and state posts, used authoritarian methods of domination. The class approach to the constitution served as a justification for the use of violence against social strata that did not share the goal of a revolutionary transition to a socialist society ${ }^{40}$.

The logic of revolutionary authoritarianism, as rightly noted by A. Galkin and $\mathrm{Yu}$. Krasin, had deep internal contradictions ${ }^{41}$. The fact is that people consist of individuals and social groups that have different interests, hopes, convictions. The constitution can integrate and allow coexistence of all these social strata only with the relatively free regulation of the legal and political space. Otherwise, the authoritarian power of the revolutionaries, pretending to be the role of the speaker of the will of the people and the common good, inevitably evolves until the domination of the political minority, which imposes their will on all the citizens.

Consequently, the Constitution of 1919 performed not the function of a limitation of state power, in contrast to the liberal constitutions of the late XVIII century, but the function of justification of political power, not limited by law and justice, such as based on revolutionary legitimacy and expediency $^{42}$.

The political significance of proletariat dictatorship has survived in subsequent constitutions adopted after the formation of the USSR. The provisions on the dictatorship of the proletariat existed in the Constitutions of the USSR of 1929 and 1937. In the process of political evolution, the social basis of the proletariat dictatorship gradually expanded. First, the social strata that emerge as a result of the freedom of economic activity, which was prohibited in the Soviet state, were eliminated. Secondly, through the system of local councils, ordinary people were involved in the state control under the political control of the ruling party of the Bolsheviks. Thirdly, the social policy of the Soviet state contributed to the growth of the welfare of Soviet citizens, although the Communist Party remained the main interpreter of what was considered as "common good". One can agree that the dictatorship of the proletariat was "intended to enlighten the masses, drawing them into the practical work of building a new society, and then giving way to a people's power" 43 . The strategic goal of transforming the dictatorship of the proletariat into a regime of

${ }^{40}$ Д.М. Бєлов. Структура та зміст конституиії, р. 86.

${ }^{41}$ А.А. Галкин, Ю.А. Красин. Россия на перепутье: авторитаризм и демократия: варианты развития, Юридическая литература, Москва 1995, р. 23.

42 Д.М. Бєлов. Структура та зміст конституиії, р. 87.

43 Е.А. Лукьянова. Значение Конституции СССР 1977 2. в развитии источников российского государственного права. «Государство и право». 4 (2001), р. 22. 
democracy has influenced the development of the concept of the selfgovernment of the working people, which envisaged a widespread and wide replacement of forms of government by forms of public self-government.

After the death of J. Stalin and the condemnation of a person's cult during the reign of $\mathrm{M}$. Khrushchev, the doctrine of a nation-state that was embodied in the norms of the Constitution of 1978 began to form. This doctrine included several elements that reflected both continuity with the former doctrine of the dictatorship of the proletariat and the novelty of understanding the social activity of the state and tasks of political development.

The doctrine of the state of the whole people was intended to show the destruction of class contradictions within the Soviet society, which was based, as argued by the official ideology, on the alliance of workers, peasants, and intellectuals. A political alliance of two classes and a stratum (the intelligentsia, in the Marxist sense, could not be a class by definition) testified that the Soviet constitution had reached its highest level of development and had the widest possible social base. The absence of social strata capable of expressing disagreement or opposing the constitution created the appearance of general agreement and political approval of the social and legal order.

Expansion of political participation of Soviet citizens through the system of councils was accompanied by the preservation of political monism of the party - the state. Some weakening of the principle of political monism consisted in the fact that non-party citizens began to be admitted to public positions, and in the elections, with the preservation of a non-alternative voting, a single bloc of "communists and non-parties" was to be nominated.

The constitution of the state of the whole people preserved traditionally the Soviet approach to the ratio of collective and individual. It was mostly collectivist in nature and set the interests of the state and society above the interests of the individual ${ }^{44}$. The constitutional civil and political rights and freedoms, broadly enshrined in the constitutional text, did not have a detailed mechanism of guarantees both at the legislative level and at the level of judicial protection.

After August 1991, the collapse of the USSR was inevitable, leading to the cessation of the 1977 Constitution of the USSR, with changes and additions. Granting the status of a sovereign state to Ukraine has transformed the Constitution of the Ukrainian SSR in 1978 with amendments and additions from the constitution of one of the Union republics to the Basic Law of an independent state. This Constitution continued to

${ }^{44}$ В. Селіванов. Право і влада суверенної України: методологічні аспекти. Юридична думка. Київ 2002, р. 108. 
operate in the transitional period from 1990 to 1996 with changes in the political struggle of reform forces and forces that sought to revive the Soviet political system. Adopted for a monolithic society in the conditions of the political hegemony of the ruling party, this constitution was not clearly adapted to appease political conflicts by legal means. The changes reflected the multidisciplinary aspirations of various political forces. The Constitution failed to put an end to the confrontation between the legislative and executive powers, unable to withstand a change in the balance of political forces and rising socio-political tension.

The 1996 Constitution of Ukraine has a fundamentally different nature, related to new socio-political realities. The nature of the 1996 Constitution was largely determined by the political events that took place during its elaboration and on the eve of its adoption. However, the transformations that took place after 1996 in various fields of social and public life, a certain period of validity of constitutional norms indicate a gradual change of socio-political content of the Constitution of Ukraine ${ }^{45}$.

That is why today the constitutional process in Ukraine is gaining momentum and, at the same speed, concerns grow in circles of lawyers about the consequences of the adoption of the Basic Law. On the one hand, everyone understands that the Constitution of 1996 initially contained in its text a lot of inaccuracies, contradictions, insubordination, and references to laws that have not yet been adopted, and their fate is covered with the darkness of ignorance. This was accompanied by changes adopted under the influence of the political moment at the end of 2004. On the other hand, there is an extremely dangerous tendency to politicize the process of drafting and adopting the Constitution. Instead of lawyers and legal scholars, politicians and political consultants try to deal with this matter. As a result, there is a deadlock situation. The current Constitution does not quite satisfy the society, and this is bad, but another option may be even worse. In fact, the ongoing political struggle, which is barely covered by legal clothing, takes place against the backdrop of too low informing the society about its essence and the problems of the constitutional process.

\section{CONCLUSIONS}

Consequently, the main and still unresolved issue is the ambiguity of what is proposed to adopt: a new Constitution, a new version of the current Constitution, amendments and additions to the current Constitution. Although paradoxical, but in Presidential speeches, these terms are used

${ }^{45}$ В. Селіванов. Право і влада суверенної Украӥни: методологічні аспекти. Юридична думка. Київ 2002, р. 109. 
repeatedly as synonyms. However, legally they are completely different concepts. This terminological confusion carries a great danger of loss of landmarks and prevents a clear statement of the problem in a purely legal area.

Thus, we believe that the constitutional process is too politicized today. In our opinion, the acutest political struggle is underway for adopting a form of constitution that is convenient for one of the parties. But in fact for power - everyone wants a maximum of power. Including through their Constitution enforced in some way. However, the Basic Law should be adopted not from the conjuncture considerations of political expediency, but be a complete legal document, taking into account the achievements of the world jurisprudence, with the strict observance of all the prescribed legal procedures. After all, the constitution should be the main document of the state, at least for a decade.

\section{SUMMARY}

The scientific publication is devoted to highlighting the peculiarities of the legal nature of the constitution. The authors consider the structure and content of the constitution of the state in the context of its functions. The specificity of the content of the newest constitutions in the history of world constitutionalism is considered. The correlation between the constitution and the state policy is established. Modern approaches to understanding the nature of the constitution are considered. The legal nature of the Constitution of Ukraine is determined.

\section{REFERENCES}

1. Bielov, Dmytro M. 2010. "Struktura ta zmist konstitucii: okremi aspekti.” Naukovijj visnik Uzhgorodskogo nacionalnogo universitetu. Seria Pravo 14(1):80-87.

2. Chyrkin, B.E. 1999. Ob obekte konstitucionno-pravovogo regulirovanija. Rossijjskijj konstitucionalizm: problemy i reshenija: materiały mezhudunarodnojj konferencii. Moskva: Akademija.

3. Cippelius, Rajjngold. 2000. Filosofija prava. Kiev: Tandem.

4. Eremenko, Yurij P. 1982. Sovetskaja Konstitucija i zakonnst. Saratov: Izd-vo SGU.

5. Farberov, N. P. 1979. "Novaja Konstitucija SSSR - manifest ehpokhi stroitelstva kommunizma." In N.P. Farberov, Konstitucija razvitogo socializma, 67-81. Moskva: Voskhod-A.

6. Galkin, Aleksandr A., and Yurij Krasin. 1995. Rossija na perepute: avtoritarizm i demokratija: varianty razvitija. Juridicheskaja literatura.

7. Gladunjak, Ivan. 2007. "Konstitucija jak osnova fotmuvannja ta realizacii derzhavnoi politiki.” Viche 21-22:11-12. 
8. Khejjvud, Eh. 2005. Politologija. Moskva: Juniti-Dana.

9. Koliushko Igor, and Yurij Kirichenko. 2001. "Problemi dievosti Konstitucii Ukrajini ta udoskonalennja ii zmistu”. Parlament 3:12-15.

10. Kozlova, Ekaterina I., and Oleg Kutafin. 2003. Konstitutsionnoe pravo Rossii. Moskva: Jurist.

11. Kravec, Igor A. 2003. "Suchhnost konstitucijj i konstitucionnyjj process (dinamika socialno-politicheskogo soderzhanija rossijjskikh konstitucijj)”. Vesnik Moskovskogo 4:34-39.

12. Kresinoi, Irina O. (edited by). 2006. Politika, pravo $i$ vlada $v$ konteksti transformacijjnikh procesiv $v$ Ukraini. Kiev: Institut derzhavi i prava im. V.M. Koreckogo NAN Ukraini.

13. Lenin, Vladimir I. 1980. Polnoe sobranie sochinenijj. Vol. XXXVI. Moskva: Politizdat.

14. Luchin, Viktor O. 1997. Konstitucionnye normy i pravootnoshenija: uchebnoe posobie [dla vuzov]. Moskva: Ehksmo.

15.Luchin, Viktor O. 2002. Konstitutsiya Rossijskoj Federatsii. Problemy realizatsii. Moskva: Juniti-Dana.

16. Lukjanova, Elena A. 2001. "Znachenie Konstitucii SSSR 1977 g. v razvitii istochnikov rossijjskogo gosudarstvennogo prava.” Gosudarstvo i pravo 4:22-27.

17. Marks, Karol, and Fridrich Engels. 1991. Sochinenija. Vol. I. Moskva: Politizdat.

18. Onishhenko, Olga V. 2005. Konstitucija Ukraini jak osnovne dzherelo konstitucijjnogo prava Ukraini. Kiev: Konsum.

19. Opryshko, Vitalijj F. 2000. Konstitucija Ukraini - osnova sistemi nacionalnogo zakonodavstva. Kiev: Vidavnichijj Dim «Juridichna Kniga».

20.Prieshkina, Olga V. 2009. Konstitucijjnijj lad Ukraini ta jogo rol u stanovlenni ta rozkvitu miscevogo samovrjaduvannja. Kiev: Institut zakonodavstva Verkhovnoi Radi Ukraini.

21. Redlich, Norman, Bernard Schwartz, and John Attanasio. 1995. Understanding Constitutional Law. Irwin: Matthew Bender.

22. Reiman, Jeffrey. 1988. "The Constitution, Rights, the Conditions of Legitimacy.” In Constitutionalism: The Philosophical Dimension, edited by Alan S. Rosenbaum, 132-139. New York: Greenwood Press.

23. Sajó, András. 1999. Limiting Government. An Introduction to Constitutionalism, Budapest: Central European University Press.

24. Salygin, Evgenijj N. 1999. Teokraticheskoe gosudarstvo. Moskva: Juridicheskaja literatura.

25. Savchyn, Michael B. 2009. Konstitucionalizm i priroda konstitucii. Monografija. Uzhgorod: Poligrafcentr «Lira». 
26. Selivanov, Volodimir. 2002. Pravo i vlada suverennoi Ukraini: metodologichni aspekti. Kiev: Juridichna dumka.

27. Shapoval V. M. 1997. Konstituciyne pravo zarubizhnih krayin: Pidruchnik. Kiev: ArtEk Vishha shk.

28. Shapoval, Vladimir. 2008. "Fenomen konstitutsii v kontekste otechestvennoy politiko-pravovoy «mifilologii»." Zerkalo nedeli 9 August, 29:4.

29. Shevchuk, Stanislav. 2002. Osnovi konstitucijjnoi jurisprudencii. Navch. posibnik. Kharkiv: Konsum.

30. Sjukijajjnen, Leonid R. 1986. Musulmanskoe pravo: voprosy teorii $i$ praktiki. Moskva: Nauka.

31.Sjukijajjnen, Leonid R. 1997. Shariat i musulmansko-pravovaja kultura. Moskva: Armada.

32. Stecjuk, Petro B. 2004. Osnovy teorii konstytucji ta konstytucjonalizmu. Chastyna persha: posibnyk dlja studentiv. Lviv: Astroljabija.

33. Stepanov, Igor M. 1984. Konstitucija i politika. Moskva: Izd-vo Nauka.

34. Stuchka, Petr I. 1929. "Dvenadcat let revoljucii gosudarstva i prava.” Revoljucija prava 6:56-61.

35. Todyka, Yurij N. 2000. Konstitucija Ukrainy: problemy teorii i praktiki. Kharkiv: Fakt.

36. Tyhomyrov, Yurij A., and I. V. Kotelevskaya. 1999. Pravovye akty: uchebnoprakticheskoe i spravochnoe posobie. Moskva: Jurinformcentr.

37. Yudin, Yurij L. 1987. "Konstitucii." In Konstitucionnoe pravo razvivajushhikhsja stran: predmet, nauka, istochniki, edited by Veniamin E. Chirkin, 38-42. Moskva: Juridicheskaja literatura.

\section{Information about the authors: \\ Bielov D. M.,}

Doctor of Law, Professor, Department of Constitutional Law and Comparative Law,

Uzhhorod National University

4, Narodna Sq., Uzghhorod, 88000, Ukraine

Vikhliaev M. Yu.,

Doctor of Law, Professor, Department of Administrative, Financial and Informative Law,

Uzhhorod National University 4, Narodna Sq., Uzghhorod, 88000, Ukraine 


\section{HUMAN RIGHTS FOR LIFE: EXPERIENCE OF UKRAINE}

\section{Hromovchuk M. V., Rohach O. Ya.}

\section{INTRODUCTION}

According to Article 3 of the Constitution of Ukraine, man, his life and health, honour and dignity, inviolability and security are recognized in Ukraine as the highest social value ${ }^{1}$. Human life serves as the object of legal protection because it is the state that should create mechanisms that would maximally protect life from any encroachment.

Life is the greatest and most important social and legal benefit of a personality. As N. Matuzov notes, "the right to life is the first fundamental natural right of a person, without which all other rights lose meaning",2. Agreeing with the above-mentioned opinion, S. Chernychenko claims that "without the provision of the right to life, the question of observance of other rights and freedoms becomes a senseless" ${ }^{3}$.

The right of a person to life is very important in order to attract the attention of scientists. Such an aspect of the right to life as a death penalty is reflected in the works of A. Meziaiev, A. Malko, A. Nikyforov, V. Kartashkin, B. Tuzmukhamedov, T. Fomichenko, and other scholars. Works by A. Abashydze, Yu. Antonian, B. Ashavskyi, M. Biriukov, H. Veliaminov, S. Yehorov, B. Zymnenko, A. Kapustin, A. Kovalov, A. Kolodkin, V. Kotliar, A. Moiseiev, I. Lukashuk, Ye. Liakhov, N. Matuzov, Yu. Romashov, Yu. Rybakov, O. Khlestov, S. Chernychenko are devoted to the international legal aspect of the right to life. In the modern Ukrainian science, the following scholars devoted their papers to certain aspects of the right to life: M. Buromenskyi, V. Yevintov, V. Denysov, L. Zablotska and others.

\section{Statement of the basic material}

Regulations of the Criminal Code of Ukraine (hereinafter - CC of Ukraine) $^{4}$ on 05.04.2001 № 2341-III (as amended) do not contain

${ }^{1}$ Конституція України: Закон України від 28.06.1996 № 254к/96-ВР [Електронний pecypc] - Режим доступу : http://zakon2.rada.gov.ua/laws/show/254\%D0\%BA/96-\%D0\%B2\% D1\%80.

2 Матузов Н. И. Право на жизнь в свете российских и международных стандартов / Н.И.Матузов // Правоведение. - 1998. - № 1. - Р. 26.

${ }^{3}$ Черниченко С.В. Еще раз о международной правосубъектности индивида / С.В.Черниченко // Московский журнал международного права, 2005. - № 4. - С. 16.

${ }^{4}$ Кримінальний кодекс України від 05.04.2001 року № 2341-III (із змінами та доповненнями) // (Відомості Верховної Ради України (ВВР), 2001, № 25-26, ст. 131). 
provisions on the mandatory consideration of decisions and legal positions of the Constitutional Court of Ukraine in the course of criminal proceedings. However, part 1 of Article 3 of the CC of Ukraine notes: legislation of Ukraine on criminal responsibility is the Criminal Code of Ukraine that is based on the Constitution of Ukraine and generally accepted principles and norms of international law.

One of the most important judgments in the practice of the Constitutional Court of Ukraine for criminal legal relations is Judgment on 29 December 1999 N 11-pп/99 known as Judgment on Death Penalty. In particular, in the operative part of the judgment, the Court ruled that the provisions of Article 24 of the General Part and the provisions of sanctions of articles of the Special Part of the Criminal Code of Ukraine, which provide for the death penalty as a form of punishment, shall be regarded as not in conformity with the Constitution of Ukraine (are unconstitutional) ${ }^{5}$. The mentioned decision N 11-pп/99 not only influenced criminal legal relations but also, in general, the status of Ukraine as a state moving towards recognizing and implementing the ideas of humanism.

On this occasion, it is important to draw attention to the legal substantiation and positions of the Constitutional Court of Ukraine, which are indicated in the above-mentioned judgment.

Consequently, the Court emphasizes that the Constitution of Ukraine recognizes the person, his/her life and health, honour and dignity, inviolability and safety as the highest social value (part one of Article 3), and the establishment and assurance of human rights and freedoms - the main responsibility of the state (part two of Article 3).

Interpretation of provisions of parts one and two of Article 27 of the Constitution of Ukraine in the context of all other provisions of the Constitution of Ukraine as a single holistic document gives grounds for asserting that they do not impose the death penalty as a form of punishment. In favour of such a conclusion, the tendency of the application of the Convention for the Protection of Human Rights and Fundamental Freedoms on the 1950 year ratified by the Verkhovna Rada of Ukraine (Law of Ukraine "On Ratification of the Convention on the Protection of Human Rights and Fundamental Freedoms, 1950, First Protocol and Protocols N 2, 4, 7 and 11 to the Convention” on 17 July

\footnotetext{
${ }^{5}$ Рішення Конституційного суду України у справі за конституційним поданням 51 народного депутата України щодо відповідності Конституції України (конституційності) положень статей 24, 58, 59, 60, 93, 190-1 Кримінального кодексу України в частині, що передбачає смертну кару як вид покарання (справа про смертну кару) [Електронний ресурс] - Режим доступу : http://zakon3.rada.gov.ua/laws/show/v011p710-99.
} 
1997, as amended by the Law of Ukraine on 24 March 1999, in particular, the provisions of Article 3 of the Convention) is evidenced ${ }^{6}$.

The key to recognizing the human right to life under the Constitution of Ukraine is the provision, according to which this right is inalienable (part one of Article 27), indefeasible, and inviolable (Article 21). The right to life belongs to a person from birth and is protected by the state.

\section{Constitution and right for life}

The Constitution of Ukraine declares that constitutional rights and freedoms, in particular, the right to life, are guaranteed and cannot be abolished (part 2 of Article 22), which prohibits any changes to the Constitution of Ukraine if they provide for the abolition of human rights and freedoms (part one of Article 157). It is also not allowed to narrow the content and scope of existing rights and freedoms, including the inalienable right to life, in the event of adoption of new ones or amendments to existing laws (part three of Article 22).

Consequently, in its content, the provisions of part 2 of Article 22 of the Constitution of Ukraine provide, on the one hand, the duty of the state to guarantee constitutional rights and freedoms, first of all, the right to life, and, on the other hand, to abstain from the adoption of any acts that would lead to the abolition of constitutional rights and freedoms, and hence human rights to life. Proceeding from the provisions of part two of Article 8 of the Constitution of Ukraine, the norm of part two of Article 22 shall be taken into account when adopting laws and other normative legal acts aimed at regulating the relevant social relations. The deprivation of a person's life by the state as a result of the use of the death penalty as a form of punishment, even within the limits set by the law, is the abolition of the inalienable human right to life, which does not correspond to the Constitution of Ukraine.

Therefore, the relevant provisions of the Criminal Code of Ukraine, which provide for the use of the death penalty, contradict the aforementioned provisions of the Constitution of Ukraine.

According to Article 23 of the Constitution of Ukraine, each person has a right to free personal development, provided that the rights and freedoms of other people are not violated. The Constitution of Ukraine, which enshrines the inalienable right to life of every person (part one of

\footnotetext{
${ }^{6}$ Про ратифікацію Конвенції про захист прав і основних свобод людини 1950 року, Першого протоколу та протоколів N 2, 4, 7 та 11 до Конвенції: Закон України від 17 липня 1997 року із змінами, внесеними Законом України від 24 березня 1999 року [Електронний pecypc] - Режим доступу: http://zakon2.rada.gov.ua/laws/show/475/97-\%D0\%B2\%D1\%80.
} 
Article 27) and protects this right from cancellation (part two of Article 22), establishes at the same time the provision that everyone has the right to protect their lives and health, life and health of other people from unlawful encroachment (part three of Article 27). In accordance with the provision of part 5 of Article 55 of the Constitution of Ukraine, everyone has the right, by any means not prohibited by law, to protect their rights and freedoms from violations and unlawful encroachments.

The Constitution of Ukraine does not contain any provisions on the possibility of using the death penalty as an exception to the provisions of part one of Article 27 of the Constitution of Ukraine on the inalienable right to life of every person. Thus, the death penalty as a form of punishment provided for in the relevant provisions of the Criminal Code of Ukraine cannot be considered an exception to the inalienable right to life of every person enshrined in the Constitution of Ukraine. Provisions of the Criminal Code of Ukraine on the use of death penalty as a form of punishment should be considered as not provided by the Constitution of Ukraine restrictions on the inalienable right to life of every person and should be recognized as inconsistent with the Constitution of Ukraine (unconstitutional).

Expanding the content of the inalienable right to life of every person, enshrined in part one of Article 27 of the Constitution of Ukraine, one should also take into account the non-compliance of the death penalty with the purposes of punishment and the possibility of a miscarriage of justice, when execution of a sentence against a person sentenced to death does not make it possible to correct its consequences, which is not in accordance with the constitutional guarantees of the protection of human rights and freedoms (Article 55 of the Constitution of Ukraine).

Given the fact that Ukraine is a social, democratic, and legal state (Article 1 of the Constitution of Ukraine), in which life and health, honour and dignity, inviolability and human security are recognized as the highest social value (Article 3 of the Constitution of Ukraine), the death penalty as a type of punishment should be considered as such, which does not comply with the specified provisions of the Constitution of Ukraine.

\section{The Criminal Code of Ukraine and right for life}

With regard to the provisions of Article 25 of the Criminal Code of Ukraine regarding the replacement of the death penalty with another form of punishment, this issue is subject to a decision in the legislative process (paragraph 14 of part one of Article 92 of the Constitution of Ukraine). 
The arguments put forward in its Judgment on Death Penalty, the Constitutional Court of Ukraine is an example of the Court's ability to use the gains from all possible sources (legal doctrine, political and legal representations, principles of constructing the modern world, international legal documents, moral principles, etc.) in order to substantiate its decision.

In the practice of courts of general jurisdiction, this Judgment No. 11-pп/99 and its legal positions are still used in our time. This is evidenced in particular by the decision of the High Specialized Court of Ukraine for Civil and Criminal Cases on 17 March 2016 ${ }^{7}$.

In criminal cases on review of newly discovered circumstances, convicted persons and their representatives use the Judgment of the Constitutional Court of Ukraine No. 11-рп/99 as arguments about the possibility of revision of decisions on condemnation, expressed in the motive parts of decisions of courts of general jurisdiction, in particular, in acts of higher courts, one can refer to the judgment of the High Specialized Court for Civil and Criminal Cases on 24 July $2015^{8}$, the judgment of the High Specialized Court for Civil and Criminal Cases on 14 April 2015 ${ }^{9}$, the judgment of the High Specialized Court for Civil and Criminal Cases on 13 November $2014^{10}$.

In this category of cases, in particular, those specified in the decision of the High Specialized Court for Civil and Criminal Cases on 13 November 2014, sentenced to life imprisonment, individuals apply to the courts of appeals with an application for review of the sentence for newly discovered circumstances, in which they raise the issue of the replacement of the imposed punishment for imprisonment for a specified period. In the justification of the above, it is noted that at the time of the commission of a crime in 1999, the sanction of Art. 93 of the CC of Ukraine (1960) provided for alternative sentences in the form of imprisonment for a term from 8 to 15 years or death penalty; by Judgment of the Constitutional Court of Ukraine No. 11-pп/99 on 29 December 1999, the provisions of

\footnotetext{
${ }^{7}$ Ухвала Вищого спеціалізованого суду із розгляду цивільних та кримінальних справ від 17 березня 2016 року [Електронний ресурс] // Режим доступу до ресурсу: http://www.reyestr.court.gov.ua/Review/56552340.

${ }^{8}$ Ухвала Вищого спеціалізованого суду із розгляду цивільних та кримінальних справ від 24 липня 2015 року[Електронний ресурс] // Режим доступу до ресурсу: http://www.reyestr.court.gov.ua/Review/47465255.

${ }^{9}$ Ухвала Вищого спеціалізованого суду із розгляду цивільних та кримінальних справ від 14 квітня 2015 року [Електронний ресурс] // Режим доступу до ресурсу: http://www.reyestr.court.gov.ua/Review/43626016

${ }^{10}$ Ухвала Вищого спеціалізованого суду із розгляду цивільних та кримінальних справ від 13 листопада 2014 року [Електронний ресурс] // Режим доступу до ресурсу: http://www.reyestr.court.gov.ua/Review/42766411.
} 
the sanctions of the Special Part of the Criminal Code of Ukraine (1960), which provided for the death penalty as a form of punishment, were declared unconstitutional, and the punishment in the form of life imprisonment was established only on the basis of the Law of Ukraine on 22 February 2000, № 1483-III, which entered into force on 4 April 2000. Based on the above, in the opinion of the convict, only the punishment in the form of imprisonment for a term up to 15 years was applied to him as such as envisaged by the sanction of Art. 93 of the CC of Ukraine (1960) as of 31 March 2000, that is, on the day of the sentence.

\section{CONCLUSIONS}

Thus, we believe that despite the contradiction in the current state of understanding of the concept of "legal positions of the Constitutional Court of Ukraine" by the scientific doctrine of constitutional law, they play a significant role in the establishment and consolidation of the rule of law and correct legal understanding in order to protect the rights and freedoms of man and citizen in Ukraine. The consistency of legal positions of the Constitutional Court of Ukraine is an important sign of ensuring the operation of principles of the constitutional jurisdiction body and principles of the Constitution of Ukraine, in particular, the need to ensure a unified legal understanding and methodological basis for the justification of a decision in one or another case, especially in the field of work of courts of general jurisdiction. The analysis of the rule-making activity of the decisions of the CCU gives grounds to say that the CCU in its decisions analyses only the signs and elements of the constitutional human right to life.

\section{SUMMARY}

The article reveals the peculiarities of the normative and legal consolidation of the human right to life. The authors pay attention to the provisions of the decisions of the Constitutional Court of Ukraine that carry out the interpretation of the human right to life.

\section{REFERENCES}

1. Конституція України: Закон України від 28.06.1996 № 254к/96-ВР [Електронний ресурс] - Режим доступу : http://zakon2.rada.gov.ua/ laws/show/254\%D0\%BA/96-\%D0\%B2\%D1\%80.

2. Матузов Н. И. Право на жизнь в свете российских и международных стандартов / Н.И.Матузов // Правоведение. - 1998. - № 1. C. 25-31. 
3. Черниченко С.В. Еще раз о международной правосубъектности индивида / С.В. Черниченко // Московский журнал международного права, 2005. - № 4. - С. 16-26.

4. Кримінальний кодекс України від 05.04.2001 року № 2341-III (із змінами та доповненнями) // (Відомості Верховної Ради України (BВP), 2001, № 25-26, ст. 131)

5. Рішення Конституційного суду України у справі за конституційним поданням 51 народного депутата України щодо відповідності Конституції України (конституційності) положень статей 24, 58, 59, 60, 93, 190-1 Кримінального кодексу України в частині, що передбачає смертну кару як вид покарання (справа про смертну кару) [Електронний ресурс] - Режим доступу : http://zakon3.rada.gov.ua/ laws/show/v011p710-99.

6. Про ратифікацію Конвенції про захист прав і основних свобод людини 1950 року, Першого протоколу та протоколів № № 2, 4, 7 та 11 до Конвенції: Закон України від 17 липня 1997 року із змінами, внесеними Законом України від 24 березня 1999 року [Електронний pecypc] - Режим доступу: http://zakon2.rada.gov.ua/laws/show/475/ 97-\%D0\%B2\%D1\%80.

7. Ухвала Вищого спеціалізованого суду із розгляду цивільних та кримінальних справ від 17 березня 2016 року [Електронний ресурс] // Режим доступу до ресурсу: http://www.reyestr.court.gov.ua/Review/ 56552340.

8. Ухвала Вищого спеціалізованого суду із розгляду цивільних та кримінальних справ від 24 липня 2015 року[Електронний ресурс] // Режим доступу до ресурсу: http:/www.reyestr.court.gov.ua/Review/ 47465255.

9. Ухвала Вищого спеціалізованого суду із розгляду цивільних та кримінальних справ від 14 квітня 2015 року [Електронний ресурс] // Режим доступу до ресурсу: http:/www.reyestr.court.gov.ua/Review/ 43626016.

10. Ухвала Вищого спеціалізованого суду із розгляду цивільних та кримінальних справ від 13 листопада 2014 року [Електронний pecypc] // Режим доступу до ресурсу: http://www.reyestr.court.gov.ua/ Review/42766411

11. Моткова О. Право на життя у рішеннях Конституційного Суду України та Свропейського суду з прав людини / О. Моткова // Вісник Конституційного суду України - 2015 - № 1 - С. 49-59.

12. Byelov Dmytry. Ochrana l'udských a občianskych práv a slobôd advokácie na Ukrajine / Dmytry Byelov // Ludské práva včera a dnes 
pôvod a význam l’udských práv a ich ochrana v právnej teórii i praxi : Medzinárodná vedecká konferencia „Banskobystrická škola právnych dejín“ 3. ročník (Univerzita Mateja Bela, Právnická fakulta BANSKÁ BYSTRICA, 15. - 16. marca 2017). - S. 15-19.

13. Бєлов Д.М. Система міжнародної кримінальної юстиції та захист основоположних прав людини: окремі аспекти // Реформування законодавства Укрїани та розвиток суспільних відносин в Україні: питання взаємодії: Матеріали міжнародної науково-практичної конференції, м. Ужгород, 17-18 лютого 2017 року - м. Ужгород: Ужгородський національний університет, 2017 - С. 201-208.

14. Byelov Dmytry Enforcement of the constitutional right of the individual to information in social networks / Dmytry Byelov // Конституційно-правові академічні студії - 2017 - № 1 - С. 7-11.

15. Бєлов Д., Жежихова М., Роль та місце інституту адвокатури в механізмі захисту прав і свобод людини і громадянина / Д. Бєлов, М. Жежихова // Visegrad Journal on Human Rights: Vedecký časopis Fakulty práva Paneurópskej vysokej školy. - 2016. - № 5/1. - C. 19-26.

16. Громовчук М.В. Конституційно-правове закріплення евтаназії в зарубіжних країнах / М.В.Громовчук // Конституційно-правові академічні студії. - 2016. - № 2. - С.32-38.

17. Громовчук М.В. Конституційна система захисту прав і свобод людини та громадянина: питання теорії/ М.В. Громовчук // Конституційно-правові академічні студії. - 2017. - № 1 - С. 18-26.

18. Громовчук М.В. Евтаназія в зарубіжних країнах: окремі питання конституційно-правового закріплення / М.В. Громовчук // Реформування законодавства України та розвиток суспільних відносин: питання взаємодії Матеріали Міжнародної науково-практичної конференції (21-22 квітня 2017 року, м. Ужгород). - С. 15-21.

\section{Information about the authors: Hromovchuk M. V.,}

Candidate of Juridical Sciences, Associate Professor, Department of Constitutional Law and Comparative Law, Law Faculty, Uzhhorod National University 4, Narodna sq., Uzghhorod, 88000, Ukraine Rohach O. Ya., Doctor of Juridical Sciences, Professor, Vice-Rector for Academic Policy and Research,

Uzhhorod National University 4, Narodna sq., Uzghhorod, 88000, Ukraine 


\section{REGULATION OF FREEDOM OF ACCESS TO ENVIRONMENTAL INFORMATION IN THE LEGISLATION OF THE EUROPEAN UNION AND UKRAINE}

\section{Kachuriner V. L.}

\section{INTRODUCTION}

In the 21st century, mankind faced specific threats to the environment due to air, water and soil pollution, reduced species biodiversity and climate change. These trends contribute to the creation of an appropriate legal framework and to greater accountability for environmental pollution. Thus, environmental protection has become the subject of numerous national, supranational and international legal norms. In addition, international environmental activities cannot be considered separately from related economic issues and social problems. Environmental protection is now a key issue on the political agenda and an important problem, both at national and European and international levels.

The global nature of environmental problems necessitates the further development of international environmental law as a legal basis for international environmental cooperation. Environmental concepts, standards and principles are usually specified in regional and bilateral agreements, and detailed regulation is carried out at national level, as appropriate. However, European Union law has a particularly significant impact on both international and national environmental law. The most intensive national and international regulation of environmental protection is carried out on the European continent, and the most successful environmental problem is solved in the context of European integration. This is evidenced by the legal experience of implementing environmental policy at both the European Union and Member States level.

Environmental protection is one of the priority areas of the European Union's activities, which defines the EU's competence in the field of environmental protection and causes the adoption of a large number of panEuropean regulations. The development of European environmental law is characterized by the search for optimal approaches to solving complex problems of natural resource management. Thus, in the Association Agreement between Ukraine and the European Union, Article 360-366 of 
Section V, "Economic and Sectoral Cooperation"1 ${ }^{1}$, is devoted to the environment itself. The Parties to the Agreement cooperate on environmental issues and thus contribute to the achievement of the goals of sustainable development and the "green economy". Analysis of EU environmental legislation is essential to further improve and improve the effectiveness of environmental legislation in Ukraine. The priority of Ukraine's cooperation with the European Union will be of practical importance achieving the goal of improving the level of production productivity, expanding its base of economic growth and competitiveness, studying and introducing experience and basic developments in the field of environmental human rights and citizens. It is advisable to draw attention to the various doctrinal developments in the field of protection of environmental human rights, both in general in the EU legal system and in respect of a particular type of rights, the right to access environmental information.

In recent years, many EU environmental law researchers have put on the agenda the question of whether national laws of EU Member States, as well as EU unified law, have sufficient legal basis to protect the interests of society against the dangers of environmental problems, or to seek additional guarantees of respect for the fundamental right of the individual - the right to a clean environment.

\section{The principle of access to environmental information}

\section{in international law}

The interdependence of environmental protection, peace, human rights and freedoms was first reflected in the Stockholm Declaration of $1972^{2}$. This principle was subsequently developed and substantially supplemented in other international instruments. In particular, the next step in the development of citizens' environmental rights in international law was the UN Conference on Environment and Development, held in June 1992 in Rio de Janeiro, which adopted a number of important international instruments ${ }^{3}$, in including the Declaration and Agenda for the 21st Century. The 21st Century Agenda, which is the plan of action of the

1 Угода про асоціацію між Україною, з однієї сторони, та Європейським Союзом, Європейським Співтовариством 3 атомної енергії і їнніми державами-членами, 3 іншої сторони. URL : http://www.kmu.gov.ua/control/publish/article?art_id=246581344.

2 Декларация Конференции Организации Объединенных Наций по проблемам окружающей человека среды 1972 г. URL: http://www.un.org/ru/documents/decl_conv/ declarations/declarathenv.shtml.

${ }^{3}$ Доклад Конференции Организации Объединенных Наций по окружающей среде и развитию Рио-де-Жанейро, 3-14 июня 1992 года A/CONF.151/26/Rev.1 (Vol. I). Нью-Йорк : Организация Объединенных Наций. 1993. С. 7-8. 
International Community for Environment and Sustainable Development, states that environmental issues are addressed with the participation of all concerned citizens. States contribute to informing society by providing widespread access to environmental information. At the 3rd Sofia Conference of Ministers of the Environment of Europe in 1995, guidelines for access to environmental information were adopted. In June 1998, at the 4th Conference of Ministers of the Environment, held in Aarhus (Denmark), 35 countries of Europe signed the Convention on Access to Information, Public Participation in Decision-making and Access to Justice in Environmental Matters ${ }^{4}$ which was subsequently ratified by both the European Union and Ukraine, and therefore a further analysis of the provisions of this Convention is common to both the EU and Ukraine. Paragraph 3 of Art. 2 of the Aarhus Convention lists the information that should be considered environmental. So, this is information about: the state of the components of the environment and their interaction: the state of the atmosphere and the air, the state of water, the state of the soil, the state of landscapes, the state of natural objects, biological diversity and its components, including genetically modified organisms; factors that influence or are capable of affecting the components of the environment: substances, energy, noise, radiation; activities that affect or may affect environmental components; measures that affect or may affect environmental components: administrative measures, environmental agreements, environmental policy, legislation, plans, programs, justifications for environmental decisions; cost-benefit analysis and other economic analysis and assumptions used in the environmental decision-making process; the state of health and safety of people, living conditions, the state of objects of culture and structures to the extent that they are affected or may be affected by the state of the environmental components ${ }^{5}$.

On 17 February 2005, the Council of the European Union signed the Decision $^{6}$ which adopted the Aarhus Convention. The convention is based on the assertion that better awareness and involvement of the public in environmental issues will help to strengthen the environment. The purpose

\footnotetext{
${ }^{4}$ Конвенція ООН про доступ до інформації, участь громадськості в процесі прийняття рішень та доступ до правосуддя з питань, що стосуються довкілля (Орхуська Конвенція) : Міжнародний документ від 25.06.1998. URL: http://www.unece.org (ECE/CEP/43).

${ }^{5}$ Правове регулювання відносин в сфері довкілля в Європейському Союзі та в Україні / За заг. ред. В.Г. Дідика. К., 2007. С. 98.

${ }^{6}$ Council Decision 2005/370 of 17 February 2005 on the conclusion, on behalf of the European Community, of the Convention on access to information, public participation in decision-making and access to justice in environmental matters Convention on access to information, public participation in decision-making and access to justice in environmental matters. Official Journal. 2005. L 124. P. 1-20.
} 
of the Convention is to promote the protection of every person of the present and future generations to live in an environment conducive to health and well-being. By signing the Convention, its Parties have declared that each Party guarantees the right to access to information, to public participation in decision-making and to access to justice in environmental matters, without discrimination on grounds of nationality, nationality or place of residence, and in the case of a legal person, without discrimination on the basis of its registered location or actual center of business.

Drawing on the main provisions of the Aarhus Convention, we can conclude that the Convention is based on three fundamental principles that are closely related.

1. The principle of access to environmental information. The Convention gives a broad concept of environmental information that covers not only the state of environmental components such as air, water, soil, landscape, biological species, including genetically modified organisms; but also such factors as energy, noise and radiation, as well as activities or activities, including administrative measures, environmental agreements, policies, legislation, plans and programs that affect or may affect environmental components, economic analysis data; health and safety of people, their living conditions; the status of cultural objects to the extent that they are or may be affected by the state of the environment. It is important that the information can be obtained without justification for the interest of having it, and in the form in which it is requested, and as soon as possible, but no later than four weeks. The applicant should be informed of any extension of the deadlines and the reasons for this. The Convention sets out the grounds for refusing to provide information, including the obviousness of the unreasonableness or non-formulation of the request and/or incompleteness of the requested material. A request for environmental information may also be refused if its disclosure could adversely affect the confidentiality of public authorities, international relations, national defense or public security, the administration of justice, the confidentiality of commercial and industrial information, personal data, intellectual property rights, etc. Information on harmful emissions into the environment may not be confidential. In cases where there is a threat to the environment or human health as a result of its activities or due to natural phenomena, all information that could enable the public to take measures to prevent or reduce harm should be disseminated immediately. States should ensure that public authorities have at their disposal environmental information pertaining to their type of activity and that mandatory systems are in place to ensure that public authorities receive appropriate information on planned and implemented activities that could 
have a significant environmental impact. Parties to the Convention should organize lists, registers or archives, and provide free access to the public. Each of the countries that have acceded to the Convention should ensure a gradual increase of information in electronic databases, which should be easily accessible to the general public. In accordance with the provisions of the Convention, information available through public communications networks to the general public should include, inter alia: environmental reports, texts of environmental legislation, policy documents, plans and programs, related to the environment or related environmental protection agreements and other information that may facilitate the application of national law to comply with the provisions of the Convention.

2. The principle of public participation in decision-making. The concerned public should be adequately, timely and effectively informed of environmental decisions of the authorities. In particular, under the Convention, it is information on the type of activity to be decided, the nature of such decisions, the procedure, time and place of their adoption, as well as the public authority responsible for decision-making and, most importantly, the possibility of public participation in making the above decisions. However, in order to ensure the most effective public participation in the environmental decision-making process, the provisions of the Convention provide for the need to provide the public with sufficient information for the time being. With regard to public participation in decision-making on specific activities that have or may have an environmental impact, it should be noted that under the Convention, the public authorities of each Party, in accordance with national law, provide the public concerned with free access to all information regarding a particular question. The Convention also provides a list of components that should include such information, including a description of the industrial site, a description of the most significant environmental factors, a description of measures to prevent or reduce such an impact, consideration of the main alternatives considered by the applicant and more. The Annex to the Convention provides a list of activities that may affect the environment and which the public has the right to participate in. The public participation process gives her the opportunity, during open hearings or consideration of such matters, to comment and to comment in writing or otherwise. In doing so, each country, in accordance with the provisions of the Convention, provides the conditions under which the results of public participation would be duly taken into account in the decision. Particular attention should be paid to the fact that, under the Convention, it is possible for the public to participate in the preparation of executive acts and / or generally binding legal acts that can significantly 
affect the environment. In order to ensure this, the most important is among other activities, namely, the public is given the opportunity to express their comments directly or through representative advisory bodies. The results of public participation are taken into account as much as possible.

3. The principle of access to justice. Any citizen who believes that his or her right to information or to participate in the decision-making process has been violated may challenge the decision in a court or other independent and impartial body. The Convention requires that the review of the decision in court be expeditious and would not require payment or that such payment would be low. Decisions taken by the court are binding on the public authority that has the relevant information. Relevant representatives of the concerned public who are either sufficiently interested or believe that a violation has occurred have access to justice. The presence of interest, as the suitability of public organizations to certain criteria, is determined in accordance with national law. However, the aforementioned provisions of the Convention do not preclude the use of a preliminary dispute settlement procedure by an appropriate administrative authority where such procedure is provided for in national law. States Parties to the Convention must provide effective remedies, including injunctive relief, fair, impartial, timely and cost-free ${ }^{7}$. The Convention declared that the parties should consider establishing mechanisms to eliminate or mitigate financial and other obstacles to justice. Such mechanisms are the least prepared for implementation in Ukraine. Undoubtedly, the Aarhus Convention today is the most important document that aims at securing and realizing the environmental rights of everyone. However, it should be noted that the first steps towards the adoption of important regulations in the field of environmental rights protection, in particular the right of access to environmental information, which is now the first of the principles on which the Aarhus Convention is based, were implemented by the European Union long before the Convention was approved.

\section{The right to access environmental information in EU legislation}

Directive 2003/4/EC was signed in order to provide the parties with a single, clear and comprehensive legislative text regarding public access to environmental information. In addition, it was declared that the provisions of the Directive should comply with the Aarhus Convention in connection with the signing of the latter by the European Community.

7 Добробог Л.М. Інформаційне забезпечення реалізації прав людини на екологічну безпеку. URL: http://www-history.univer.kharkov.ua. 
The purpose of Directive 2003/4/EC is to guarantee the right of access to environmental information and to ensure the systematic and broadening of the boundaries of dissemination of environmental information to the public $^{8}$. For this purpose, the Directive provides for the use of computer telecommunications and / or electronic technologies. To this end, States Parties shall take all necessary measures to ensure that public authorities have access to environmental information and to further disseminate such information through computer telecommunications and / or electronic technology, if available. According to the Directive, the information to be made available is, in particular: the texts of international agreements, conventions and agreements of the Community, national, regional and local legislation in the field of the environment; public policies, programs and plans for the environment; State reports on the state of the environment (to be published at least every 4 years); data on actions that affect the environment and more.

In accordance with the provisions of Directive 2003/4/EC, Member States should guarantee the accessibility and openness of environmental information held by a public authority or a public authority to any person requesting it. In this case, the requesting person does not need to formulate his/her interest. In order to comply with the guarantees above, the Parties are obliged to ensure that: officials support the public in accessing information; the list of public authorities was made available to the general public; practical measures have been identified to enable the effective exercise of the right of access to environmental information. Some innovation is that Member States ensure that public authorities properly inform the public about the rights they enjoy under this Directive and provide information and advice to that effect. However, Directive 2003/4/EC provides that, where the request is very broadly formulated, the public authority asks the person to clarify the request and helps him to do so, in particular by providing information on the use of public registers. The Directive provides for cases where requests for environmental information may be rejected, which generally comply with the provisions of the Aarhus Convention. At the same time, it is noted that in each case, public authorities should compare the public interest in disclosure and the interest that is the basis for refusal (to set priorities). The directive prohibits the rejection of a request if it is related to environmental information.

\footnotetext{
${ }^{8}$ Directive 2003/4/EC of the European Parliament and of the Council of 28 January 2003 on public access to environmental information and repealing Council Directive 90/313/EEC. Official Journal. 2003. L 041. P. 26-32.
} 
As regards the payment of environmental information, the Directive provides that the relevant public authorities may impose a fee for the provision of any information, but such a fee should not exceed a reasonable amount. At the same time, the rates of such payment should be published, as well as information on the conditions under which the fee may be charged. Much of Directive 2003/4/EC is devoted to one of the three fundamental principles on which the Aarhus Convention is based, namely, the principle of "public access to justice". In accordance with the provisions of the Directive, Member States shall ensure that any requesting person who considers that his or her request for information has been ignored, for which the request was incorrectly rejected (in whole or in part), or received or incorrectly answered the request was not considered in accordance with the provisions of the Directive, had access to a procedure for reviewing actions or omissions by this or other public authority or administrative review by an independent and impartial body established by law. The provisions of the Directive on the speed and free (moderation of payment) of such review are also fully in line with the Aarhus Convention. In addition to the review procedure, Member States should ensure that the requesting person has access to the review procedure by a court or any other independent and impartial body established by law, which may consider the actions or omissions of the relevant public authorities, and decisions of which may be final. In this case, the final decisions are binding on the executing public authority. Member States are also allowed to provide that third parties accused of disclosing information also have access to legal redress. Directive 2003/4/EC regulates the obligation for Member States to ensure that information is not outdated, accurate and comparable.

Case law already has 541 cases brought to light in the light of Directive 2003/4/EC ${ }^{9}$. Computer telecommunications and / or electronic equipment are used for this purpose. L. Kremer points out that as of 2007, the European Court of Justice had issued around 400 decisions. He is trying to interpret modern environmental law ecologically friendly and to strengthen the environment ${ }^{10}$. In his work, A.L. Dubovyk gives a report to the judge

${ }^{9}$ Reference for a preliminary ruling from the Najvyšší súd Slovenskej republiky (Slovak Republic) lodged on 23 August 2010 - Jozef Križan and Others v Slovenská inšpekcia životného prostredia. Official Journal. 2010. C 301. P. 11-12; Reference for a preliminary ruling from the Tribunal administratif de Paris (France) lodged on 12 November 2009 - Ville de Lyon v Caisse des dépôts et consignations. Official Journal. 2010. C 37. P. 29; Request for a preliminary ruling from the Unabhängiger Verwaltungssenat Wien (Austria) lodged on 17 June 2013 - Ferdinand Stefan. Official Journal. 2013. C. 274. P. 2-3.

10 Кремер Л., Винтер Г. Экологическое право Европейского Союзу / отв. ред. О.Л. Дубовик. М. : Городец, 2007. С. 40. 
of the Belgian Constitutional Court, L. Lavriesen, whom he delivered at a conference entitled "30 Years of EU Environmental Law" and emphasized that: "In the years of its activity, the Court of Justice has developed a series of general doctrines that have fostered efficiency. European law in general. These doctrines are also important for the development of environmental European law"11 ${ }^{11}$ However, in its decisions it establishes only the right, or more precisely, the competence of Union bodies to regulate any sphere, until the obligation to take measures based on the principles and aspects of environmental policy has been established in court. However, it is necessary to interpret the contents of these general provisions with some caution, since only the core of this program of obligations is protected by judicial protection. Anything that goes beyond this is subject to the legislature. L. Lavriesen emphasizes: "Since 7 February 1985, when the judgment in the L'Association de defense de brulenrs $d$ huiles usages was decided, the Court recognizes that environmental protection is a "mandate requirement" which, in the absence of full harmonization legislation may justify the use of measures restricting trade in Member States"12.

Directive 2003/35/EC promotes the providing for public participation in respect of the drawing up of certain plans and programmes relating to the environment and amending with regard to public participation and access to justice $^{13}$. Member States shall enable the public to participate in the preparation and modification, revision of plans or programs. To this end, the following should be ensured: informing the public, either by public announcement or by other appropriate means, of such plans or programs; the public has the right to comment and decide on plans and programs; in making these decisions, due account should be taken of the results of public participation; having considered the comments and opinions expressed by the public, the competent authority shall use its best endeavors to inform the public of the decision and the reasons and considerations on which these decisions are based, including information on the public participation process.

${ }_{11}$ Дубовик О.Л. Экологическое право ЕС: формирование, развитие, достижения и актуальные задачи. Право и политика. 2004. № 12. С. 65.

${ }^{12}$ Степаненко В.С. Понятие и правовое значение принципов экологической политики ЕС. Политика и общество : Научный гуманитарный журнал. 2006. № 6. С. 91-92.

${ }^{13}$ Directive 2003/35/EC of the European Parliament and of the Council of 26 May 2003 providing for public participation in respect of the drawing up of certain plans and programmes relating to the environment and amending with regard to public participation and access to justice Council Directives 85/337/EEC and 96/61/EC - Statement by the Commission. Official Journal. 2003. L 156. P. 17-25. 
Undoubtedly, the layer of EU uniform legislation on the protection of environmental information rights is much wider. However, the directives mentioned are groundbreaking, because they laid the foundations for further development of EU law in this area.

\section{Legislation of Ukraine in the field of access to environmental information}

Regarding the legislative and regulatory acts of Ukraine governing the legal relations in the field of access to environmental information such as the Constitution of Ukraine, the Law of Ukraine "On Information"14 of 02.10.1992, the Law of Ukraine "On Environmental Protection"15 of 25.06.1991, Law of Ukraine "Fundamentals of Legislation on Health Care" $^{16}$ of 19.11.1992, Law of Ukraine "On Ensuring Sanitary and Epidemic Well-Being of the Population" ${ }^{17}$ of 24.02 .1994 , Law of Ukraine "On Nuclear Energy Use and Radiation Safety" ${ }^{18}$ vi 02/02/1995, Law of Ukraine "On Ratification of the Convention on Access to Information, Public Participation in Decision-Making and Access to Justice in Environmental Matters"19 of 06.07.1999, Law of Ukraine "On Environmental Expertise" $^{20}$ dated 9 February 1995 and others.

Environmental information plays a leading role in environmental security. First of all, such information is necessary for the preparation and adoption of economic, management and other decisions, the implementation of which is associated with the negative impact of human activity on the environment. Environmental information can be used by citizens to protect their environmental rights, as well as a basis for interfering with unsatisfactory environmental activities of the state, business structures, especially if the latter do not fulfill the tasks assigned to them by law. In Ukraine, the definition of "information" is enshrined in

${ }^{14}$ Про інформацію : Закон України від 02.10.1992 № 2657-XII. Відомості Верховної Ради Украӥни. 1992. № 48. Ст. 650.

15 Про охорону навколишнього природного середовища : Закон від 25.06.1991 № 1264-ХІІ. Відомості Верховної Ради Украӥни. 1991. № 41. Ст. 546.

16 Основи законодавства України про охорону здоров'я : Закон від 19.11.1992 № 2801-XII. Відомості Верховної Ради України. 1993. № 4. Ст. 19.

${ }^{17}$ Про забезпечення санітарного та епідемічного благополуччя населення : Закон від 24.02.1994 № 4004-XII. Відомості Верховної Ради України. 1994. № 27. Ст. 218.

18 Про використання ядерної енергії та радіаційну безпеку : Закон від 08.02.1995 № 39/95-ВР. Відомості Верховної Ради Украӥни. 1995. № 12. Ст. 81.

${ }^{19}$ Про ратифікацію Конвенції про доступ до інформації, участь громадськості в процесі прийняття рішень та доступ до правосуддя 3 питань, що стосуються довкілля : Закон України від 6 липня 1999 року № 832-XIV. Офіційний вісник Украӥни. 1999. № 28. Ст. 2.

${ }^{20}$ Про екологічну експертизу : Закон від 09.02.1995 № 45/95-ВР. Відомості Верховної Ради України. 1995. № 8. Ст. 54. 
a number of legislative acts. However, the most general definition covering all types of information is provided in the Law of Ukraine "On Information". According to this Law, information is the documented or publicly announced information about events and phenomena occurring in society and the state and the environment. The classification of information at the legislative level is also enshrined in the Law of Ukraine "On Information", which refers not only to types of information but also to its industry. Article 3 of the aforementioned law establishes the obligation of the state to constantly ensure the timely creation, proper functioning and development of information systems, networks, banks and databases in all areas of information activities, which fully complies with the obligation established by Directive 2003/4/EC ${ }^{21}$. Member States shall take all necessary measures to ensure that the relevant public authorities have access to the information and that such information is systematic, accurate and up-to-date. The state guarantees freedom of information activities in these areas to all citizens and legal entities within the limits of their rights and freedoms, functions and powers. In general, the country has a well-developed system of regulations on the collection, accumulation, dissemination and access to environmental information. Among these are, in particular, the Law of Ukraine "Fundamentals of Healthcare Legislation" $^{22}$, since environmental status is known to be an important factor affecting human health. The Law stipulates that one of the main means of ensuring the right of citizens to health protection from adverse environmental impact is the right of a person to have accurate and timely information about the state of their health and the health of the population, including existing or possible risk factors and their degree.

All the above-mentioned provisions of the Acts implement the principle of the Aarhus Convention on Public Access to Environmental Information, and also comply with the provisions of a number of EU Directives. However, the most important and substantive rules on the subject under investigation are usually contained in the Constitution of Ukraine. The constitutional norm of part two of Art. $34^{23}$, which enshrines the right to information, includes the ability to collect, store, use and disseminate any information orally, in writing or otherwise, at its

${ }^{21}$ Directive 2003/4/EC of the European Parliament and of the Council of 28 January 2003 on public access to environmental information and repealing Council Directive 90/313/EEC. Official Journal. 2003. L 041. P. 26-3.2

${ }^{22}$ Основи законодавства України про охорону здоров’я : Закон від 19.11.1992 № 2801ХІІ. Відомості Верховної Ради України. 1993. № 4. Ст. 19.

${ }^{23}$ Конституція України : Закон від 28.06.1996 № 254к/96-ВР. Відомості Верховної Ради Украӥни. 1996. № 30. Ст. 141. 
discretion. Another provision of the Constitution of Ukraine enshrines the right of everyone to free access to information on the state of the environment, the quality of food and household goods, as well as the right to disseminate such information. The above information cannot be kept secret by anyone. This fully complies with the basic principles underlying EU legislation on access to environmental information, in particular the purpose of Directive 2003/4/EC. Based on Part 2 of Art. 50 of the Constitution, the right to access environmental information has three elements: it is the right to access information on the state of the environment, on the quality of food and household goods.

Information on the state of the environment is environmental information. The legislator, in adhering to this position, identifies the concepts of "information on the state of the environment" and "environmental information". On the one hand, there is a ban on taking certain actions on environmental information, on the other - there is a need to respect this right by any natural or legal person, as well as the state. Considering that the Constitution of Ukraine has the highest legal force, and laws and other legal acts are adopted on its basis and must comply with it, it can be argued that the provisions of the legislation of Ukraine, which set restrictions on access of citizens to environmental information, are unconstitutional $^{24}$. A characteristic feature of the right of access to environmental information, which distinguishes it from general information rights, is precisely the third element that excludes, under normal conditions, restrictions on environmental information. However, in conditions of martial law or emergency, in accordance with Part 2 of Art. 64 of the Constitution of Ukraine, individual restrictions on rights and freedoms may be established with an indication of the duration of these restrictions. The content of the above constitutional norms was reflected by the legislator even before the adoption of the basic law of Ukraine in the Law "On Environmental Protection". In particular, the provisions of this Law enshrined, among the basic principles of environmental protection, publicity and democracy in decision making, the implementation of which affects the state of the environment and the formation of ecological outlook among the population. Article 9 of the Law ${ }^{25}$ enshrines the right of every citizen to have free access to information on the state of the environment (environmental information) and the free receipt, use, dissemination and storage of such information, with

\footnotetext{
${ }^{24}$ Бойченюк I. Екологічна інформація та комерційна таємниця. Вісник екологічноі адвокатури. 2006. № 30. С. 12-16.

25 Про охорону навколишнього природного середовища : Закон від 25.06.1991 № 1264-XII. Відомості Верховної Ради Украӥни. 1991. № 41. Ст. 546.
} 
the exception of restrictions established by law; the right to participate in public environmental expertise, to obtain environmental education.

Publicly available information - any environmental information, with the exception of special environmental information, in turn, specific environmental information includes data reflecting the specific activities of individual central sectoral public authorities dealing with defense and national security issues, as well as subject to trade secrets, confidentiality and other data which the right may be denied in accordance with the law. The principle of remuneration, which may be applied by the relevant authorities in providing environmental information, however, the fee charged for such information may not exceed the cost of copying, retrieving and preparing information in one form or another, which is fully in line with similar provisions of EU law. Each State Party has undertaken to guarantee the right of access, receipt and dissemination of information to all environmental information subjects regarding the publication of environmental information, national and regional projects planned, national economic development programs and the rest. Such basic obligations of the parties fully reflect the purpose of Directive 2003/4/EC.

According to European environmental law researchers M. Anderson and A. Boyle, over time, some European Parliament and European Commission officials have sought to broaden the scope of information on EU environmental activities and to involve citizens and grassroots movements and groups in direct involvement in environmental protection. Catastrophes (such as Chornobyl) indicate what fatal consequences a lack of information can have ${ }^{26}$. A key element of an effective right of access to information is that stakeholders may not be particularly persistent in obtaining information.

Concerning the implementation of the Ukrainian legislation of the directives within the framework of the Association Agreement, it is worthwhile to note that the Ukrainian legislator should plan work on making the appropriate changes to the normative legal acts of Ukraine in order to ensure the functioning of legal instruments operating in the EU. The system of Ukrainian legislation does not contain a separate normative legal act or provisions regarding public access to environmental justice in the context of another normative legal act whose main purpose is the implementation of all principles of the Aarhus Convention and Directive

\footnotetext{
${ }^{26}$ Boyle A.E., Anderson M.R. Human right approaches to Environmental protection. New York : Oxford University Press, 1996. P. 25-42.
} 
2003/4. Access to information shall be foreseen, by leading rank, in accordance with the Law of Ukraine "On Access to Public Information" ${ }^{27}$.

Also, the legislation of Ukraine does not clearly define the concept of plans and programs in accordance with Directive 2003/35/EC, therefore it is advisable to take this into account in the relevant legislative act or acts, since the assessment of the environmental impacts of the implementation of plans and programs is one of the voluntary instruments for regulating environmental issues.

\section{CONCLUSIONS}

Basic principles of access to environmental information are enshrined in both Ukrainian and European legislation, ratification of a key document in the research area - the UN Convention on Access to Information, Public Participation in Decision-making and Access to Justice in Environmental Matters implementation of the provisions of the said Convention. However, the list of environmental information in the Law of Ukraine "On Environmental Protection" is narrower than in the Aarhus Convention and Directive 2003/4/EC.

The system of Ukrainian legislation lacks a separate legal act or provision regarding public access to environmental justice as part of another legal act, the main purpose of which is to implement all the principles of the Aarhus Convention. In Ukraine, the information component of environmental policy is extremely weak. It is obvious that the origins of the problem are concentrated in the absence of a system of environmental education and public education that should shape the ecological culture and public consciousness, thereby saturating the information space with this problem. Relevant central government and local government bodies, institutions of higher and secondary education, libraries, NGOs and the media can do much more to inform and raise public awareness of the state of particular natural resources and the environment in general. To do this, the state should formulate its own information, education and education policy in these matters and consolidate it at the legislative level by adopting a single consolidated legal act.

Against this background, it can be noted that the EU's environmental policy is seen as one of the driving forces behind the modernization of public administration in Ukraine. Within the framework of the Association Agreement between Ukraine, on the one hand, and the European Union, the European Atomic Energy Community and their Member States, on the

${ }^{27}$ Про доступ до публічної інформації : Закон від 13.01.2011 № 2939-VI. Відомості Верховної Ради України. 2011. № 32. Ст. 314. 
other hand, our country is required to borrow and implement extensive EU legislation in the field of environmental protection and environmental protection. Significant private and public investment in the industry. However, for the sustainable development of environmental legislation, in particular the right to environmental information, a careful harmonization with EU law is needed. This process should be selective and take into account local conditions, national interests and priorities.

\section{SUMMARY}

The article deals with the analysis of EU environmental legislation. It's essential to further improve and increasing the effectiveness of environmental legislation in Ukraine. An important step in this direction is the right of access to environmental information.

The author analyzes the application of the principle of participation and informing citizens in the legislation of Ukraine in accordance with the provisions of the Association Agreement with the EU. The Association Agreement with the European Union is aimed at securing and realizing the environmental rights of everyone. Every citizen has the right to free access to information about the state of the environmental information and the free acquisition, use, distribution and storage of such information.

The author emphasizes that Ukraine is taking steps to ensure that public authorities have environmental information, as well as create the conditions for further dissemination of such information through computer telecommunications or electronic technologies.

\section{REFERENCES}

1. Бойченюк I. Екологічна інформація та комерційна таємниця. Вісник екологічної адвокатури. 2006. № 30. С. 12-16.

2. Декларация Конференции Организации Объединенных Наций по проблемам окружающей человека среды 1972 г. URL: http://www.un.org/ ru/documents/decl_conv/declarations/declarathenv.shtml.

3. Добробог Л.М. Інформаційне забезпечення реалізації прав людини на екологічну безпеку. URL: http://www-history.univer.kharkov.ua.

4. Доклад Конференции Организации Объединенных Наций по окружающей среде и развитию Рио-де-Жанейро, 3-14 июня 1992 года A/CONF.151/26/Rev.1 (Vol. I). Нью-Йорк : Организация Объединенных Наций.1993. 519 с.

5. Дубовик О.Л. Экологическое право ЕС: формирование, развитие, достижения и актуальные задачи. Право и политика. 2004. № 12. C. 58-67. 
6. Конвенція ООН про доступ до інформації, участь громадськості в процесі прийняття рішень та доступ до правосуддя з питань, що стосуються довкілля (Орхуська Конвенція) : Міжнародний документ від 25.06.1998. URL: http://www.unece.org (ECE/CEP/43).

7. Конституція України : Закон від 28.06.1996 № 254к/96-ВР. Відомості Верховної Ради Украӥни. 1996. № 30. Ст. 141.

8. Кремер Л., Винтер Г. Экологическое право Европейского Союзу / отв. ред. О.Л. Дубовик. М. : Городец, 2007. 144 с.

9. Основи законодавства України про охорону здоров'я : Закон від 19.11.1992 № 2801-XII. Відомості Верховної Ради України. 1993. № 4. Ст. 19.

10.Правове регулювання відносин в сфері довкілля в Європейському союзі та в Україні / За заг. ред. В.Г. Дідика. К., 2007. 579 с.

11.Про використання ядерної енергії та радіаційну безпеку : Закон від 08.02.1995 № 39/95-ВР. Відомості Верховної Ради Украӥни. 1995. № 12. Ст. 81.

12.Про доступ до публічної інформації : Закон від 13.01.2011 № 2939-VI. Відомості Верховної Ради Украӥни. 2011. № 32. Ст. 314.

13.Про екологічну експертизу : Закон від 09.02.1995 № 45/95-ВР. Відомості Верховної Ради Украӥни. 1995. № 8. Ст. 54.

14.Про забезпечення санітарного та епідемічного благополуччя населення : Закон від 24.02.1994 № 4004-XII. Відомості Верховної Ради України. 1994. № 27. Ст. 218.

15.Про інформацію : Закон України від 02.10.1992 № 2657-XII. Відомості Верховної Ради Украӥни. 1992. № 48. Ст. 650.

16.Про охорону навколишнього природного середовища : Закон від 25.06.1991 № 1264-ХІІ. Відомості Верховної Ради Украӥни. 1991. № 41. Ст. 546.

17.Про ратифікацію Конвенції про доступ до інформації, участь громадськості в процесі прийняття рішень та доступ до правосуддя 3 питань, що стосуються довкілля : Закон України від 6 липня 1999 року № 832-XIV. Офіиійний вісник Украӥни. 1999. № 28. Ст. 2.

18. Степаненко В.С. Понятие и правовое значение принципов экологической политики ЕС. Политика и общество : Научный гуманитарный журнал. 2006. № 6. С. 83-93.

19.Угода про асоціацію між Україною, 3 однієї сторони, та Європейським Союзом, Свропейським Співтовариством з атомної енергії i їхніми державами-членами, 3 іншої сторони. URL : http://www.kmu.gov.ua/control/publish/article?art_id=246581344. 
20.Boyle A.E., Anderson M.R. Human right approaches to Environmental protection. New York : Oxford University Press, 1996.

21. Council Decision 2005/370 of 17 February 2005 on the conclusion, on behalf of the European Community, of the Convention on access to information, public participation in decision-making and access to justice in environmental matters Convention on access to information, public participation in decision-making and access to justice in environmental matters. Official Journal. 2005. L 124. P. 1-20.

22. Directive 2003/35/EC of the European Parliament and of the Council of 26 May 2003 providing for public participation in respect of the drawing up of certain plans and programmes relating to the environment and amending with regard to public participation and access to justice Council Directives 85/337/EEC and 96/61/EC - Statement by the Commission. Official Journal. 2003. L 156. P. 17-25.

23. Directive 2003/4/EC of the European Parliament and of the Council of 28 January 2003 on public access to environmental information and repealing Council Directive 90/313/EEC. Official Journal. 2003. L 041. P. 26-32.

24. Reference for a preliminary ruling from the Najvyšší súd Slovenskej republiky (Slovak Republic) lodged on 23 August 2010 - Jozef Križan and Others v Slovenská inšpekcia životného prostredia. Official Journal. 2010. C 301. P. 11-12.

25. Reference for a preliminary ruling from the Tribunal administratif de Paris (France) lodged on 12 November 2009 - Ville de Lyon v Caisse des dépôts et consignations. Official Journal. 2010. C 37. P. 29.

26. Request for a preliminary ruling from the Unabhängiger Verwaltungssenat Wien (Austria) lodged on 17 June 2013 - Ferdinand Stefan. Official Journal. 2013. C 274. P. 2-3.

\section{Information about the author:} Kachuriner V. L.,

$\mathrm{PhD}$, Associate Professor at the Department of State Law Disciplines, International Humanitarian University 33, Fontanskaya road str., Odessa, 65009, Ukraine 


\section{WAYS OF PUBLIC-LAW DISPUTE RESOLUTION}

\section{Kivalov S. V.}

\section{INTRODUCTION}

The updated Code of Administrative Proceedings of Ukraine has brought to the legal reality of the Ukrainian state changes that determine the development of justice in Ukraine in line with world trends. These changes also concern the implementation of mechanisms for the settlement of publiclaw disputes: through mediation and dispute settlement with the participation of an administrative court judge. For the countries of the Romance-Germanic legal family, the issue of alternative ways of resolving legal conflicts has become urgent due to the rethinking of the role of the modern state, its purpose, the nature of interaction with civil society and every citizen. For a "consensus society" dominated by the idea of tolerance, absolute recognition of other people rights and interests as one's own, compromise settlement becomes a priority form of conflict resolution. In addition, such a way to resolve conflicts most closely fits into the landmark movement to minimize the functions of the modern state, which declares the development of service relations between the government and the individual through enhanced private initiative, delegation of public functions or, at least, diversification of the subjects of their realization ${ }^{1}$.

There is no doubt that litigation is the most effective way of protecting legal rights, but in some cases, adjudication does not yet mean a genuine resolution of the conflict and, on the contrary, it may provoke its escalation ${ }^{2}$. It was in the context of changing the ideology of the functioning of the modern state that a discussion was started on expanding the range of ways of alternative settlement of public-law disputes and the expediency of their support at the state level. Thus, Recommendation No. R (81) 7 identified ways of facilitating reconciliation and mediation as a way of facilitating access to justice ${ }^{3}$. Such procedures are complementary to traditional

1 Дзевелюк М.В. Сервісна держава як функціональна модель сучасної держави. Актуальні проблеми держави і права. 2017. Вип. 78. Ст. 60-67, р. 67

${ }^{2}$ Подковенко Т.О. Медіація як один з альтернативних способів розв'язання юридичних конфліктів. Державо і право. Вип. 45. Ст. 31, р. 31.

${ }^{3}$ Рекомендация R(81)7 Комитета Министров государствам-членам относительно путей облегчения доступа к правосудию 14 мая 1981 г. Офіційний веб-портал Верховної Ради України. URL: https://zakon.rada.gov.ua/laws/show/994_133. 
litigation, but can not substitute or made traditional litigation impossible (except in certain cases of arbitration) in any case. At the same time, these recommendations have become specific in Ukraine: mediation as the most widespread, world-wide-established, clear and established instrument is still outside the legal field; instead, in all procedural codes (except the Code of Criminal Proceedings of Ukraine, the Code on Administrative Offences of Ukraine), a dispute settlement procedure with the participation of a judge has been implemented ${ }^{4}$. That demonstrates reverse "centripetal" processes when the state, presented by a body such as a court, does not delegate its functions to it, but on the contrary - is given an additional function that is not inherent to it. This is justified by the fact that the settlement of a dispute involving a judge does not have any features in common with justice, except that this procedure is carried out by a judge.

\section{Concepts and features of public litigation}

Law is divided into public and private due to the fact that in every system of law there are norms, which should ensure general (public) interests, the interests of society, the state, and there are rules that protect the interests of individuals. Public law encompasses several spheres of public life, above all the construction of the state and the government, including public administration, that is, the expression of public interest as a total, general social interest in each sphere of public life. In other words, public law is associated with the realization of public authority (state power and local self-government) and is characterized by the influence of the imperative method of legal regulation, which is an original, constitutive feature of public law and determines the nature of public-legal relations ${ }^{5}$. Thus, public law is the set of legal institutions, rules and norms that underpins the functioning of a structured governmental and organizational system by which the purpose of securing public order and ultimately the realization and protection of human rights is achieved through the use of the imperative method $^{6}$.

Based on the rules of public law, there are many legal links between public authorities and local self-government, citizens, legal entities,

\footnotetext{
${ }^{4}$ Про внесення змін до Господарського процесуального кодексу України, Цивільного процесуального кодексу України, Кодексу адміністративного судочинства України та інших законодавчих актів: Закон України від 03.10.17 р. № 2147-VIII. Офіційний вебпортал Верховної Ради України. URL: https://zakon.rada.gov.ua/laws/show/2147-19.

${ }^{5}$ Харитонова О. І. Адміністративно-правові відносини (проблеми теорії): монографія. О.: Юридична література. 2004. 328 с., р. 119.

${ }^{6}$ Харитонов Є. О., Старцев О. В. Цивільне право України: підручник. вид. 2, перероб. і доп. К.: Істина, 2007. 816 с., р. 12.
} 
etc., which are related to the exercise of public authority and the satisfaction and harmonization of public interests, that is, the needs of society or the needs of a particular territorial community provided by the law ${ }^{7}$. Such legal relationships are expressed in the establishment of legal personality, the legal status of these entities (which is associated with the emergence of common legal relations), and are prerequisites for establishing specific public relations, as a legal relationship between the entities of the legal sphere, which due to the presence of certain legal facts have reciprocally corresponding subjective rights and legal obligations. Considering the above, it is possible to distinguish a number of characteristic features of public-law disputes, which allow to distinguish them from private legal disputes (that arise from economic, civil, housing, land, family, labor relations, etc. $)^{8}$.

Firstly, it is the nature of particular legal relationships that arose the dispute. A dispute will be a public-law one if the disputed rights, freedoms, interests, duties, powers are realized in public-legal relationships. It is this criterion in jurisprudence that is essential to distinguish public-law disputes from disputes in private law. If the exercise of authority by a public authority occurs through specific legal relationships with other entities, in most cases such legal relationships will be just public law. However, in some cases, the exercise of public-authority functions may also occur through private-law relationships. This is due to the fact that there are no impenetrable borders between public and private law. They are interconnected. The above also applies to the field of public administration. The exercise of public authority, although is mediated primarily by the fields of public law, but analysis, for example, of the structure of publicadministrative relations, allows to state that the sphere of public administrative relations is wider than the sphere of these relations governed by the rules of administrative law ${ }^{9}$. Management is in unity with the law as a whole, with the whole system of its branches ${ }^{10}$. Due to the extraordinarily broad scope of administrative relations, they are mediated by the norms of a number of branches of law, but administrative and constitutional law are

${ }^{7}$ Bryant G. Garth (1992) Power and Legal Artifice: The Federal Class Action Law \&amp; Society Review, 26 (2), pp. 237-272, DOI: 10.2307/3053898, p. 238.

${ }^{8} \mathrm{G}$. Richard Shell (1988) The role of public law in private dispute resolution: reflections on Shearson/American express, Inc. V. McMahon. American business law journal, 26 (3): 397-433, DOI: 10.1111/j.1744-1714.1988.tb01150.x, p. 399.

9 Державне управління в Україні: навчальний посібник. За загальною редакцією В. Б. Авер'янова. К.: НАН України. Інститут держави і права ім. В.М. Корецького, 1999. Р. 19.

10 Алексеев С.С. Право и управление в социалистическом обществе (общетеоретические вопросы). Советское государство и право. 1973. № 6. Р. 13. 
of paramount importance. Therefore, legal acts of public authorities may also serve as the basis for the emergence of economic, civil, housing, land, family, labor relations (so in accordance with Part 4 of Article 11 of the Civil Code of Ukraine in cases established by acts of civil law, civil rights and obligations arise directly from acts of state authorities, authorities of the Autonomous Republic of Crimea or local self-government bodies). For example, for the exercise of their power functions, local governments may adopt acts on the transfer of communal property for rent, which are the basis for the conclusion of relevant contracts. If the dispute arises over such a contract and the question arises as to the lawfulness of the act of the local self-government body on the lease of the property, the dispute concerns private legal relations not related to the protection of rights, freedoms or interests in public-law relations, and is not public-law.

In order to determine the nature of particular legal relationships, and therefore the nature of legal dispute, it is necessary to take into account the following features of public-legal relations, which distinguish them from legal relations in private law ${ }^{11}$ :

a) these relations are related to the exercise by the State or territorial communities of their public functions, in particular as regards the protection of the rights and freedoms of man and citizen;

b) public-law interest (the desire to provide benefits that are of social importance, i.e. benefits that are important not only to one individual but to a large number of people - the community, society) dominates in these relations;

c) they are governed by the rules of public law (above all, those enshrined in the acts of constitutional, criminal, administrative, financial legislation, etc.);

d) as a rule, a party to these relations is an entity that is endowed with public authority (to recognize a public-law relationship, it is required that the entity endowed with public authority exercises these powers in such relations; as a rule, it is a state body, local self-government body, their official or official person or other entity to which the respective powers of the state or local self-government are delegated).

The exercise of public-authority functions may affect the rights, freedoms, interests of individuals and legal entities even when the legal relationship between such persons and the relevant public authority is not related to the existence of specific legal relationships (for example, when seeking protection of legitimate interest protected by the law of interest),

\footnotetext{
${ }^{11}$ Кодекс адміністративного судочинства України: науково-практичний коментар / За заг. редакцією Р. О. Куйбіди (видання друге, доповнене). К.: Юстініан, 2009. 976 с., р. 38.
} 
which, along with subjective rights and freedoms, acts as an independent object of judicial protection. Therefore, in the absence of specific legal relations between the parties to the dispute, it is necessary to determine other features of a public-law dispute, though predominantly covered by the foregoing features of public-law relations, but which have an independent significance for determining the nature of a legal dispute that arose in the absence of specific legal relations between its parties.

Secondly, public-law disputes arise in connection with the exercise of public authority, that is, certain public-power functions (which are manifested in the respective powers of public authorities). Public power is exercised, including through the implementation of public administration. This kind of public-authority activity applies to almost all spheres of society and is primarily related to the exercise of executive power and local self-government. In addition, public administration encompasses relationships that are formed within internal organizational activity within state bodies, local self-government bodies, etc. Considering the above, the vast majority of public law disputes arise in the field of public administration.

Thirdly, the subject of public-law dispute are the contradictions regarding the exercise of rights, freedoms, interests, powers in public-legal relations, as well as the exercise of public-power functions and related rights, freedoms, interests outside specific legal relations. At the same time, the exercise of public-power functions is connected with the committing or not performing (inactivity) of state bodies, local selfgovernment, their officials or officials, other entities to which the powers are delegated. These specific actions are externally manifested in public administration tools. These include, first of all, the adoption of regulatory or individual legal acts, the conclusion of public-law contracts, the implementation of other actions that have legal consequences.

Fourthly, almost always one of the parties in public-law disputes is the subject, which is vested with public-authority powers, and precisely in connection with their implementation (some public-law disputes, which are an exception to cited, for example, in Article 275-277 of the Code of Administrative Proceedings of Ukraine). Such entity shall be a public authority, local self-government body, their official or official or other entity to which the respective powers of the state or local self-government have been delegated. This subject becomes a party to the dispute precisely in connection with the exercise of power, and not in connection with the realization, for example, of its civil personality. 
Finally, fifthly, the resolution of public-law disputes requires special legal, including judicial, procedures that take into account the specifics of such disputes. This, in particular, stipulates the peculiarities of administrative justice (which is reflected in the principle of official clarification of all the circumstances of the case, the presumption of lawfulness of the claims of the plaintiff of a natural or legal person, etc.). In addition, participation in a public-law dispute of a state or local government body (their official or official), in conjunction with an imperative method of legal regulation, does not allow to speak about the widespread use and effectiveness of resolving public-law disputes in an informal way ${ }^{12}$.

Thus, on the basis of all of the above, public-law dispute can be defined as embodied in legally significant actions of the parties of the contradiction regarding the exercise of rights, freedoms, interests, powers in public-legal relations, as well as in the exercise of public-power functions and related their rights, freedoms, interests beyond specific legal relationships. It should be borne in mind that, in the course of administrative justice, not all, but only certain, public-law disputes are dealt with. The following features have been used by the legislator to identify public-law disputes that are the subject of consideration in administrative proceedings, to distinguish them from public-law disputes, which are considered under the rules of other court procedures ${ }^{13}$.

\section{Settlement of public-law dispute in administrative proceedings}

For the adjudication of public law disputes there is an institute of administrative justice. And administrative justice is a type of justice, the subject of which is public-law disputes, which is implemented in the form of administrative justice based on judicial specialization. Based on the above definition, we can define the following features of administrative justice that determine its essence:

- administrative justice is directed at consideration and settlement of public-law disputes concerning violation of rights, freedoms, interests of individuals and legal entities in the field of public administration ( material aspect ) ;

- administrative justice is carried out in a special statutory manner (procedural form) - in the form of administrative justice (administrative

\footnotetext{
12 Крохина Ю. А. Юридический конфликт в финансовой сфере: причины, сущность и процедуры преодоления. Журнал российского права. 2003. № 9. Р. 72.

${ }^{13}$ Кодекс адміністративного судочинства України: науково-практичний коментар / За заг. редакцією Р. О. Куйбіди (видання друге, доповнене). К.: Юстініан, 2009. 976 с., p. 129.
} 
process), which is adapted for effective consideration of public-law disputes and other cases in the public-legal sphere (procedural aspect);

- administrative justice is implemented on the basis of judicial specialization - specialized courts (organizational aspect).

Therefore, administrative law (the administrative process of settling public-law disputes) refers to the procedure established by law for the administrative courts to hear and resolve public-law disputes and certain other cases in cases provided for by law. The objective of administrative justice is the fair, impartial and timely resolution of disputes by the court in the field of public-legal relations in order to effectively protect the rights, freedoms and interests of individuals, rights and interests of legal entities from violations by the authorities.

From the analysis of the task of administrative justice, it becomes clear the importance of this institution for the development of a democratic, rule of law in general and the resolution of public-law disputes in particular. For the purpose of carrying out the task of administrative justice, administrative courts, when deciding on the protection of the rights, freedoms and interests of individuals and legal entities from violations by the authorities in making their decisions, committing actions or omissions, check whether they are (committed) (ch. 2 Article 2 of the Code of Administrative Proceedings of Ukraine):

1) on the basis, within the powers and in the manner defined by the Constitution and laws of Ukraine;

2) using the authority for the purpose for which the power was conferred;

3) justified, that is, taking into account all the circumstances that are relevant for the decision (action);

4) impartial (impartial);

5) in good faith, that is, with a sincere intention that the exercise of power and achievement of the set goals and fair results;

6) prudent, i.e. in accordance with common sense and generally accepted moral standards;

7) respecting the principle of equality before the law, preventing all forms of discrimination;

8) in proportion, in particular, with respect to the necessary balance between any adverse effects on the rights, freedoms and interests of the person and the purposes to which this decision is directed (action);

9) taking into account the right of a person to participate in the decision-making process;

10 ) in a timely manner, i.e. within a reasonable time. 
Given the guaranteed part 2 of Art. 55 of the Constitution of Ukraine, everyone has the right to appeal in court the decisions, actions or omissions of state bodies, local self-government bodies, officials and officials, every natural or legal person has the right to apply to an administrative court if it considers that the decision, action or inaction of a subject power violations of their rights, freedoms or legitimate interests (provided that the settlement of a dispute is adhered to in court, if the obligation of pre-trial settlement is expressly established by law) ${ }^{14}$.

In the cases provided for by law, not only individuals and legal entities but also the authorities may apply to the administrative court. Such cases involve the judicial authorization of certain decisions and the taking of certain actions, which are connected with the exercise by the authorities of those "interfering powers", which entail a significant restriction of the rights and legitimate interests of natural or legal persons (for example, establishing restrictions what about the exercise of the right to peaceful assembly, the forced dissolution of citizens' associations, the forced expulsion of foreigners and stateless persons outside Ukraine, etc.).

When settling a public-law dispute within the framework of administrative justice, certain methods of judicial protection (substantive legal measures of a coercive nature, applied by the court and by means of which an effective restoration of the violated rights, freedoms, interests of a person) are applied, namely:

recognition of a legal act or its separate provisions as illegal and invalid;

recognition as illegal and cancellation of an individual act or its separate provisions;

declaring the actions of the authority subject to unlawfulness and the obligation to refrain from taking certain actions

recognition of the inactivity of the subject of authority by unlawfulness and obligation to take certain actions;

establishing the presence or absence of competence (authority) of the subject of authority.

Simultaneously with the application of the aforementioned methods of judicial protection, an administrative court may decide on the compensation of damage caused by unlawful decisions, acts or omissions of the subject of power or other violation of the rights, freedoms and interests of subjects of public-legal relations, or claims for the claim of property withdrawn on the basis of the decision of the subject of power. Otherwise, such claims are

${ }^{14}$ Конституція України: прийнята на 5 сесії Верховної Ради України 28.06.1996 р. Офіційний веб-портал Верховної Ради України. URL: https://zakon.rada.gov.ua/laws/show/ 254\%D0\%BA/96-\%D0\%B2\%D1\%80. 
decided by the courts in civil or commercial proceedings. In addition, protection may be applied in a manner that is not expressly provided by law, but does not contradict it (Part 2, Article 5, Item 11, Part 2, Article 245 of the Code of Administrative Proceedings of Ukraine).

When applying to the administrative court of the authorities with a claim to a natural or legal person, the court, as already noted, exercises preliminary control over the lawfulness of the decision or action of the subject of power - the requirements of the subject of power are satisfied by the court, provided that they are not violate the rights, freedoms, interests of the individual. Therefore, the decision of the administrative court does not specify the methods of judicial protection of the rights, freedoms, interests of the person, but sanctions the adoption of certain decisions to commit certain actions of the subject of power.

\section{Settlement of public-law dispute through mediation}

The mediation of disputes is characterized by the fact that the search for a mutually agreed solution is not based on formal documents, but solely on the search for the balance of interests of the parties through a series of negotiations, opinions and proposals with the participation of an independent person (mediator), acting on the basis of independence and impartiality, contributes to the support and development between the parties of the culture of their relations, the achievement of positive results and mutual understanding in the dispute that has arisen between them.

The advantage of mediation over the adjudication of public-law disputes is that the judge has no capacity in the trial to apply the rules of dispute settlement, which are not provided for by specific rules of law, even if those rules are mutually beneficial for both parties, provided for by the Law; the judge is guided by the law and the available evidence in the relevant case when conducting the trial. The latter can only be interpreted as true and false and judged by them at their discretion. In mediation, either party may recognize that the other party's claims are to some extent justified and agree to a compromise solution ${ }^{15}$.

The administrative procedural legislation of Ukraine does not disclose the content of the concepts of "reconciliation" and "amicable settlement", but the analysis of judicial practice and scientific heritage allows to distinguish the following features of mediation in resolving public law disputes.

\footnotetext{
${ }^{15}$ Kaija Sandra , Reingolds Valerijs (2014) The role of mediation in public and private law in the Republic of Latvia. International Multidisciplinary Scientific Conferences on Social Sciences and Arts (SGEM 2014), Albena. Political sciences, law, finance, economics and tourism, 1: 491-498, p. 497.
} 
First of all, the content of this activity is administrative procedural action. This is mediated by the requirements for the special procedure for issuing the representative's powers. The parties have a procedural right to obtain the protection of the violated subjective right or interest of the plaintiff, protected by law, and the right to defend the defendant against the unjustified claims of the plaintiff through the settlement of the case in court. The settlement of the issue of automatic settlement of the amicable settlement in reaching a reconciliation between the parties does not have an unambiguous interpretation. Interesting in this regard is the opinion of O.G. Bortnik, according to which the disposal of substantive law in the act of reconciliation (peace agreement) is always present, than this action differs from the rejection of the claim ${ }^{16}$. However, there is another point of view: the settlement agreement deals with substantive rights, which is why the parties dispose of procedural rights. At the trial of the court are considered legal relationships, and can only be waived from the valid law ${ }^{17}$.

In addition, it can be noted that the courts are guided by the fact that when reaching a reconciliation (concluding a settlement agreement), not only procedural but also substantive rights are disposed of, so a special clause in the representative's power of attorney is required to carry out administrative actions.

Another feature that characterizes the amicable settlement is that it is a procedural action aimed at resolving the dispute by the disputing parties themselves and not by the court ${ }^{18}$. The substantive legal conflict in the ordinary course of the process is resolved by the court, which assesses the legality and validity of the claimant's claims and the defendant's objections, reflects his findings in the court decision ${ }^{19}$. By reaching a reconciliation (by concluding a settlement), the parties to the dispute thus refuse the prospect of resolving their dispute by a court, which can give a single answer about the nature and content of the legal relationship (or the lack of legal relations at all) between them (provided that the decision will be legal and justified). The

\footnotetext{
${ }^{16}$ Бортнік О.Г. Мирова угода у цивільному судочинстві : дис. канд. юрид. наук : 12.00 .03 / О.Г. Бортнік. Харківський національний ун-т внутрішніх справ. Х., 2007. 227 с., р. 118.

${ }^{17}$ Колясникова Ю.С. Примирительные процедуры в арбитражном процессе : автореф. дис. ... канд. юрид. наук. : спец. 12.00 .03 «Гражданское право и процесс; хозяйственное право» / Ю.С. Колясникова. Екатеринбург, 2009. 26 с., p. 11.

${ }^{18}$ Mimoso Maria Joao ; Anjos Maria do Rosario (2019) Administrative arbitration in public procurement: a look at Portuguese law , Juridical tribune-tribuna juridical, 9 (1): 196-205, p. 197.

19 Sandra Kaija, Inga Kudeikina (2018) Legal Scope of the Mediation and Problem of Applicability, European Journal of Sustainable Development, 7 (4): 372-380, DOI: 10.14207/ ejsd.2018.v7n4p372, p. 379.
} 
outcome of the dispute settlement by the parties themselves may not coincide with the court decision that the court would have passed had the parties not reached a reconciliation (conclusion of a settlement agreement). This conclusion is based on an analysis of the rules of the Code of Administrative Proceedings of Ukraine on the procedure for closing proceedings in connection with the parties reaching a conciliation (court approval of the terms of the settlement agreement).

To achieve the purpose of solution of the dispute, the parties agree on the terms of its solution. The terms on which the parties agree to build their relationship are recorded in the court record and signed by the parties or stated in the written statement of the court involved in the case, as indicated in the court record. The importance of clear conditions fixation of reconciliation (peace agreement) determines the special requirements for their procedural fixation. The procedural document that issues the conclusion of the case by reaching a reconciliation (concluding a settlement agreement) is a decision to close the proceedings in the administrative case. Achieving reconciliation (concluding by the parties to a settlement agreement) leads to the conclusion of the case without a court decision. However, the decision to close an administrative proceeding in connection with a reconciliation (concluding a settlement agreement) has the consequences of a court decision ${ }^{20}$ if the parties refuse to comply with the terms of reconciliation.

It should be emphasized that conciliation (amicable settlement) is a product of the will of two or more persons (the main difference between them is the refusal of the claimant and the recognition of the defendant), which is a legal fact, which leads to the termination of proceedings only in the case of his court certification - the difference between the procedural institute of reconciliation (amicable settlement) from the so-called "extrajudicial amicable agreement", which is, in essence, a normal substantive legal agreement between the parties. Approval of the conciliation (amicable settlement) by the court also stipulates the possibility of compulsory fulfillment of the terms of this agreement in case of evasion of the parties from fulfillment of the obligations stipulated by it. It is important for mediation the absence of restrictions or conditions for its application to any public-law disputes, with the aim of experimental identification of the zone of possible reconciliation, complications in reaching a compromise, negative impact on the degree of conflict of

\footnotetext{
${ }^{20}$ Основи адміністративного судочинства та адміністративного права : навч. посіб. / за заг. ред. Р.О. Куйбіди, В.І. Шишкіна. К. : Старий світ, 2006. 256 с., р. 353.
} 
relations in the field of public administration ${ }^{21}$. This approach will provide more accurate regulatory regulation of the most important elements of mediation in the future ${ }^{22}$.

Consequently, three conditions are necessary for the effective functioning of mediation in disputes:

1) high professionalism of the mediator, which clearly distinguishes the violation of the right from the offense;

2) the existence of an effective, first and foremost, available mechanism for the judicial protection of the infringed law, which in no case should be replaced by a mediation procedure, for which the establishment of justice rather than the resolution of the conflict remains a priority;

3) a high level of legal culture of the population, which creates internal personal barriers to the realization of the temptation to abuse the opportunities provided by mediation procedures.

For an effective mediation of settlement of public law disputes, such a condition as the full perception of the subject of power as a full participant in the negotiation process with an individual is also important. Thus, the Recommendation of the Committee of Ministers of the Council of Europe Rec (2001) 9 emphasizes that the widespread use of alternative administrative dispute resolution tools will help to resolve these problems and bring administrative authorities closer to the public, and one of the advantages of alternative administrative dispute resolution broad boundaries of discretion in the activities of public administration ${ }^{23}$.

At the same time, even at level of the Council of Europe, there is an understanding that the process of "dismantling" the settlement of publiclaw disputes has many obstacles, among which one of the most significant is that states have not realized the potential utility and effectiveness of alternative dispute resolution between administrative bodies and private ones and therefore do not take sufficient steps to explain to the administrative authorities the benefits of alternative models for resolving such disputes, which may lead to unconventional, effective and rational

${ }^{21}$ Richard C. Reuben (1997) Public Justice: Toward a State Action Theory of Alternative Dispute Resolution, California Law Review, 85 (3): 577-641, DOI: 10.2307/3481153, p. 577.

${ }^{22}$ Sandra Kaija, Inga Kudeikina (2018) Legal Scope of the Mediation and Problem of Applicability, European Journal of Sustainable Development, 7 (4): 372-380, DOI: 10.14207/ ejsd.2018.v7n4p372, p. 379.

${ }^{23}$ Рекомендація Rec (2001) 9 Комітету Міністрів Ради Свропи державам-членам щодо альтернатив судовому розгляду спорів міжадміністративними органами й сторонами приватними особами, ухвалена Комітетом Міністрів 5 вересня $2001 \mathrm{p}$. URL: https://vkksu.gov.ua/userfiles/doc/perelik-dokumentiv/EU_Standarts_book_web-1 .pdf. 
settlement $^{24}$. But in the current situation in Ukraine, it is almost impossible. The guidelines for better implementation of the Recommendation on Alternative Dispute Resolution between Administrative Authorities and Private Parties clearly identify the role of states: promoting the application of alternative dispute resolution methods with private parties to individual administrative acts, treaties and other controversial issues; encouraging the use of internal review, reconciliation, mediation and negotiated settlement as mandatory prerequisites for initiating court proceedings; encouraging administrative bodies to initiate alternative dispute resolution methods in all cases where such methods are not contrary to applicable law; the obligation on administrative authorities to consent to the use of alternative dispute resolution methods when required by a private party, except where such a procedure is contrary to the public interest or is abused by the private person ${ }^{25}$.

None of these measures have been implemented in Ukraine for more than ten years. Even after the new version of the Code of Administrative Proceedings of Ukraine enters into force, the law does not provide for any case where an appeal to the administrative body with a complaint is a prerequisite for filing an administrative claim. Therefore, the authority in Ukraine has no incentive to apply alternative dispute resolution procedures, but has numerous reservations about this step in the form of potential allegations of dishonesty, unlawful interest, diminished performance plans, and so on. All of this, in aggregate, testifies to the significant defects in the basis for the effective functioning of any model of alternative dispute resolution in Ukraine. The only major step in fulfilling the recommendations on the implementation of European standards in the field of justice in Ukraine is the normative fixing of dispute settlement with the participation of the judge of the administrative court in the Code of Administrative Proceedings of Ukraine. Therefore, it is necessary to study it in more details for the perfection of regulations.

\footnotetext{
${ }^{24}$ Керівні принципи для кращого виконання наявної Рекомендації про альтернативні методи розв'язання спорів між адміністративними органами і приватними сторонами, затверджені Європейською комісією 3 питань ефективності правосуддя 7.12.2007 p., CЕРЕЈ (2007) 15. URL: https://vkksu.gov.ua/userfiles/doc/perelikdokumentiv/EU_Standarts_book_web-1.pdf..

${ }^{25}$ Керівні принципи для кращого виконання наявної Рекомендації про альтернативні методи розв'язання спорів між адміністративними органами і приватними сторонами, затверджені Свропейською комісією з питань ефективності правосуддя 7.12.2007 p., СЕРЕЈ (2007) 15. URL: https://vkksu.gov.ua/userfiles/doc/perelikdokumentiv/EU_Standarts_book_web1.pdf.
} 


\section{The settlement of a public-law dispute with the participation of an administrative court judge}

The Institute for the Settlement of a Public-Law Dispute with the Participation of a Judge cannot be recognized as mediation in the classical understanding because, firstly, the mediator is an independent person, secondly, the mediation is extremely flexible and confidential, thirdly, mediation is separated from the judiciary and is its alternative.

The settlement of a dispute involving a judge can be considered as part of administrative proceedings - an optional step in the preparatory proceedings. At the same time, this approach has many objections:

the administrative procedure establishes the right to reconciliation, which is an integral part of the administrative court's activity, but the legislator regards the settlement of the dispute with the participation of a judge as a separate activity not related to reconciliation during the development of basic procedural relations, fixing the court's obligation to promote reconciliation;

the settlement of a dispute involving a judge is based on fundamentally different principles other than those enshrined in the Code of Administrative Proceedings of Ukraine (this is most evident from the principles of openness and openness of the trial and its full fixation by technical means, which directly contradicts the requirements of confidentiality in private meetings);

the judge remains unchanged for both the trial and the settlement of the dispute.

These controversies over the introduction of a dispute resolution institute with the participation of a judge are of increasing interest to scholars and practicing professionals. The vast majority of researches has been conducted on alternative ways of resolving civil disputes and the global experience of their application, conducted by Spector O. M. ${ }^{26}$, pretrial settlement of administrative and legal disputes (Beluga S. S. ${ }^{27}$, Shinkar T. I. ${ }^{28}$, Lyubchenko Ya. . $^{29}$ ). Therefore, the legitimate option of

${ }^{26}$ Спектор О.М. Альтернативні способи вирішення цивільно-правових спорів: світовий досвід та перспективи застосування у правовій системі України. Київ: Фенікс, 2013. 159 с.

27 Білуга С.С. Досудове врегулювання адміністративно-правових спорів: автореф. дис. ... канд. юрид. наук: 12.00.07. Одеса, Національний університет, «Одеська юридична академія». 2015. 22 c. URL: http://dspace.onua.edu.ua/bitstream/handle/11300/1980/ \%D0\%91\%D1\%96\%D0\%BB\%D1\%83\%D0\%B3\%D0\%B0\%20\%D0\%A1.\%20\%D0\%A1..pdf?se quence $=1 \& a m p ;$ isAllowed $=\mathrm{y}$.

${ }^{28}$ Шинкар T.I. Застосування медіації в адміністративному судочинстві: вітчизняний та зарубіжний досвід: автореф. дис. ... канд. юрид. наук: 12.00.07. Львів, Національний університет, «Львівська політехніка». 2017. 24 с. URL: http://lp.edu.ua/sites/default/files/ dissertation/2018/8401/aref_shynkar_1.pdf 
alternative conflict resolution, including in the public-legal sphere, is considered only in separate scientific articles. That is, the main focus in the study of the legal nature of the dispute settlement institute with the participation of the judge is to identify its common and distinctive features with mediation. The opposite vector of research is those that formulate the vision of the institute for the participation of a judge in resolving a publiclaw disputr through the procedural plane (M. M. Chabanenko, T. M. Lezhnev) ${ }^{30}$.

Both areas appear to be important for developing a full-fledged system of alternative ways of resolving public conflicts in modern society and for selecting among the diversity of existing classical and integrated instruments in the world the one that would be most effective in Ukraine, which is the purpose of this study.

Settlement of a dispute involving a judge in the structure of the administrative process not only destroys established theoretical constructs (which, indeed, today are of rather conditional value), but also fails to fulfill its direct purpose. Recall that the intensification of the process of developing alternative litigation procedures is related to the attempt to unload the courts, as recorded in Recommendations Rec (2001) 9 of the Committee of Ministers of the Council of Europe to Member States on alternatives to litigation between administrative authorities and parties private parties in 2001 "a large number of cases and... a steady increase in the number of cases may weaken the capacity of courts competent in administrative cases to hear cases within a reasonable time, within the meaning of Art. 6.1 of the European Convention on Human Rights”31. In contrast, the number of cases pending before a judge in no way decreases - the proceedings themselves are differentiated. Talking about simplifying the activity of a judge after implementing the procedure for settling a dispute involving a judge in the procedural codes is also unlikely, on the contrary, it is an additional burden on the judge. First, almost all judicial professionals have pointed out that mediation is a

${ }^{29}$ Любченко Я.П. Альтернативні способи вирішення правових спорів: теоретико-правовий аспект: автореф. дис. ... канд. юрид. наук: 12.00.01. Харків, Національний юридичний університет імені Ярослава Мудрого. 2018. 22 с. URL: http://nauka.nlu.edu.ua/download/ diss/Lubchenko/d_Lubchenko.pdf.

30 Чабаненко М.М., Лежнєва Т.М. Правова природа врегулювання спору за участю судді (в контексті структури цивілістичного процесу). Порівняльно-аналітичне право. 2018. № 2. C. 135-137. URL: http://pap.in.ua/2_2018/37.pdf.

${ }^{31}$ Рекомендація Rec (2001) 9 Комітету Міністрів Ради Європи державам-членам щодо альтернатив судовому розгляду спорів між адміністративними органами й сторонами приватними особами, ухвалена Комітетом Міністрів 5 вересня 2001 p. URL: https://vkksu.gov.ua/userfiles/doc/perelik-dokumentiv/EU_Standarts_book_web-1 .pdf. 
specific area of knowledge that requires special training, which, according to the current legislation, is obviously required by all judges in Ukraine ${ }^{32}$. Secondly, the ratio between the procedure for settling the dispute with the participation of a judge and the trial of the case (especially in the written procedure) through the categories "simpler - more complicated" is completely incorrect, since the former will require considerable efforts on the part of the judge, the number and duration of meetings is not regulated by law. Thirdly, in the judicial process where the rules of summary procedure are applicable, speed of decision-making of a final decision that is taken on the consequences of the dispute settlement procedure is almost the same. Nowadays the judicial process where the rules of summary procedure are applicable is the basic form of consideration and resolution of cases in administrative proceedings. Thus, under summary procedure, the case is heard within a maximum of 60 days from the date when the proceeding is started, while the term of the procedure with judge participation may take up to 120 days (60 days for the preparatory hearing +30 extra days in case when it is necessary +30 days for the dispute resolution procedure itself) in total. So, we can see that in court dispute settlement significantly loses before the mediation procedure.

The introduced dispute settlement procedure with a judge role in it could co-exist with classical mediation, especially regarding to publiclaw disputes, since mediation has additional complications and causes open opposition. The logic is simple: the more options to resolve a conflict, the better. But, in this case, there are some objections, although they are not so obvious. There is no doubt that a compromise settlement of disputes has real advantages and a humanistic implication, but it also has unattractive "reverse" as this method recognizes the assignment in one's rights as a norm. It leads to the opinion that in case of a conflict a loss of rights is inevitably, even if it is expressed in minor actions. Consequently, in the exaggerated form, the "consensus society" risks becoming a "right of the strong," which does not hesitate to state hypertrophied demands and obtain at least part of the expected advantage as a result of the conciliation procedure.

If in Ukraine there is co-existence of mediation and settlement of the dispute with the participation of a judge, a private person who is in conflict with the authority body will get additional psychological stress. Following the path of least resistance, the private person should turn to a mediator

${ }^{32}$ Конституція України: прийнята на 5 сесії Верховної Ради України 28.06.1996 р. Офіційний веб-портал Верховної Ради України. URL: https://zakon.rada.gov.ua/laws/show/ 254\%D0\%BA/96-\%D0\%B2\%D1\%80. 
whose task is to find a critical margin of assignment for the party. But when the private person is not satisfied, the only way is to take the case to a court, where the private person will settle the dispute with judge participation, that means another assignment for the private person. Provided that the above-stated procedure is unsuccessful, the "phantom of reconciliation" will not leave the private individual, because according to part 5, Art. 194 of the Code of Administrative Proceedings of Ukraine "when considering the merits of the case the court promotes a reconciliation of the parties" ${ }^{33}$. The hypertrophied view of the situation clearly demonstrates how the compliance of citizens is trained.

The analysis of critical remarks on the procedure of dispute resolution with the participation of a judge in the publications of Ukrainian scholars allows us to conclude that the majority of scholars see the following shortcomings and make the following suggestions:

1) the election of a proper judge to settle the dispute (many scholars are inclined to the need to empower individual judges, and not the entire judicial body of the court);

2) the absence of establishment of the main priorities of the dispute settlement procedure, consolidation of its principles;

3) gaps in the dispute's interrelation settlement procedure and the restarted court proceedings (possibility of applying procedural coercion measures, a violation of the settlement procedure as a basis for appealing a court decision, that was made based on its consequences, etc.).

We considered these observations to be relevant and useful for improving the existing dispute settlement procedure with the participation of an administrative court judge.

In addition, much attention should be paid to such problematic issues of the above-stated procedure as the use of procedural terminology in its regulatory framework and the power of a judge, such as to decide whether to apply the dispute settlement procedure. First of all, it should be noted that Part 4 of Art. 186 of the Code of Administrative Proceedings of Ukraine provides that clarification on the subject of evidence in the category of considered dispute to the parties shall be done by the judge ${ }^{34}$. The establishment of the subject is one of the key issues in proving justice. Traditionally, the subject of proof in a case refers to the circumstances that must be established by the court. In other words, when determining the

${ }^{33}$ Кодекс адміністративного судочинства: Закон України від 06.07.2005 р. № 2747-IV. Офіційний веб-портал Верховної Ради України. URL: https://zakon.rada.gov.ua/laws/show/ 2747-15.

${ }^{34}$ Ibid. 
subject-matter in each specific case, it is necessary to find the answer to the question: what circumstances (or facts) should be established? At the same time, the establishment of the circumstances of law violation, which became the subject of bringing lawsuit to the court, and clarification of actual rights and obligations of the parties to the dispute - "kill" the very idea of settling the dispute, because it leads to the approval of one party in their rightness and destroy any grounds for concessions. The purpose of this procedure is not to "understand the matter of a case", but to find a solution acceptable for both parties, which, at the same time, will require certain concessions from each side, otherwise it loses any meaning. Therefore, the question arises: why during the dispute settlement procedure should a judge explain to the parties the subject of the evidence in their case? In order to reach a compromise, the judge should establish the person's requirements (according to the Code of Administrative Proceedings of Ukraine they are the grounds and subject of the claim and the grounds of objections), the system of alternative proposals from each party and form a zone of possible coordination of position ${ }^{35}$. Thus, the use of the term "evidence" in a dispute resolution procedure with judge participation is incorrect and may substantially distort the very idea of this procedure as an alternative to administrative justice.

Another important direction of improving the dispute settlement procedure with the participation of the administrative court judge is to define its boundaries and to understand the transformation of the role and status of the judge which is unchanged in the initial stages of judicial proceedings in the administrative court and in the dispute settlement procedure. The Code of Administrative Proceedings of Ukraine states that such "written" boundaries are resolutions on conducting the dispute settlement procedure and on termination of the dispute settlement procedure, in which the judge decides, respectively, on the suspension and resumption of judicial proceedings in the case. In this regard, there are comments about the "priorities" of these procedural documents. Settlement of a public dispute involving a judge is a derivative procedure that can exist only in the form of court proceedings. Therefore, the court proceeding itself is a "primary" procedure, which have to be reflected in the relevant court decisions. The primary issues that should be reflected in

\footnotetext{
35 Білуга С.С. Досудове врегулювання адміністративно-правових спорів: автореф. дис. ... канд. юрид. наук: 12.00.07. Одеса, Національний університет, «Одеська юридична академія». 2015. 22 c. URL: http://dspace.onua.edu.ua/bitstream/handle/11300/1980/ \%D0\%91\%D1\%96\%D0\%BB\%D1\%83\%D0\%B3\%D0\%B0\%20\%D0\%A1.\%20\%D0\%A1..pdf?se quence $=1 \&$ amp;isAllowed $=\mathrm{y}$.
} 
court decisions (court procedural documents) are the questions of termination and restarting court proceedings. Only when these questions are resolved it should be noted in the decision that the dispute settlement procedure with the participation of a judge should be applicable or terminated.

An analysis of the content of decisions on the appointment of a dispute settlement procedure with the participation of a judge shows that the judges are not fully aware of the transformation of their tasks and thus, their status. For example, many decisions address the form of meetings (not just the first ones) ${ }^{36}$, although the form of the meeting according to the Code of Administrative Proceedings of Ukraine should be chosen by the judge as the person conducting the conciliation procedure. In addition, according to the injunction of the Codex of Administrative Proceedings of Ukraine, a closed meeting is initiated by a judge. It also raises objections. Since the judge's function in the dispute settlement procedure is to direct the parties to seek a compromise and if the parties wish to discuss the issue with the judge in the form of a closed meeting, it should not be prohibited.

The last comment on the context of the court decision is about the possibility to appeal it. In these decisions, the question of the dispute settlement procedure and the suspension of proceedings is not only interconnected, but also interdependent. There are no other grounds for the suspension of proceedings in these decisions.

At the same time, the possibility of appealing the court decision on the dispute settlement procedure is realised as follows: the court decision regarding the appointment of the dispute settlement procedure with the participation of the judge is not subjected to be appealed and comes into force from the moment of its announcement; a court decision regarding the suspension of the proceedings may be appealed ${ }^{37}$. To some extent, this can be explained by the prescription of Art. 294 of the Code of Administrative Proceedings of Ukraine, that states that the decision to terminate the proceedings is classified as an appeal, that is appealed separately from the court decision. Chapter 4 of the Code of Administrative Proceedings of Ukraine regulates the issues of dispute settlement with the participation of a judge, but it does not mention the possibility to appeal administrative court decision on its appointment. It only allows to appeal a court decision

\footnotetext{
${ }^{36}$ Єдиний державний реєстр судових рішень. Офіційний веб-портал «Судова влада». URL: http://reyestr.court.gov.ua/.

${ }^{37}$ Кодекс адміністративного судочинства: Закон України від 06.07.2005 р. № 2747-IV. Офіційний веб-портал Верховної Ради України. URL: https://zakon.rada.gov.ua/laws/show/ 2747-15.
} 
on termination of despite resolution (in that case appeal is not allowed). It turns out that appealing the decision in the part of claim suspension indicates an automatic disagreement to settle a dispute with a judge participation. Therefore, it is inappropriate to distinguish between these two issues in the decisions on a dispute settlement procedure with the participation of a judge. Although according to Art. 184 of the Code of Administrative Proceedings of Ukraine, the settlement of a dispute with the participation of a judge is carried out with the consent of the parties, and also taking into account the need to popularize this procedure, the possibility of appeal on an appeal basis is impractical ${ }^{38}$.

\section{CONCLUSIONS}

The study has found that a public-law dispute expresses a legal conflict that arises over performing public administration and the realization of public authority in which the subject of public administration is one of the parties to a public-law dispute. The dispute can be settled both in trial and at the pre-trial stage within the framework of administrative proceedings through mediation and with the participation of a judge of the administrative court. The administrative process of settling public-law disputes means the procedure established by law for the activities of administrative courts to hear and resolve public-law disputes and certain other claims in cases provided by law.

It was substantiated that a dispute settlement procedure with the participation of an administrative court judge may not be recognized as an optimal model of an alternative method of public-law dispute resolution, but it has the right to exist prior to the introduction of mediation. It is also a useful tool for the gradual expansion of the idea that the authority body is a party to a negotiating process. Legal regulation of the procedure for the settlement of disputes with the participation of an administrative court judge requires improvement. Some amendments should be made as to the refusal of using purely procedural terms. It should be supplemented with special terminology, which emphasizes the differences between this procedure and the activities of judges related to the administration of justice (preparing procedural documents related to the procedure for the settlement of disputes, involving the administrative court judge, the status and powers of the judge in this procedure).

\footnotetext{
${ }^{38}$ Кодекс адміністративного судочинства: Закон України від 06.07.2005 р. № 2747-IV. Офіційний веб-портал Верховної Ради України. URL: https://zakon.rada.gov.ua/laws/show/ 2747-15.
} 


\section{SUMMARY}

The study is devoted to clarifying the legal nature of the mechanisms of the settlement of public law disputes, which are implemented within the framework of administrative justice, through mediation and with the participation of an administrative court judge. The author stated the low level of adaptation of the existing system of public-law dispute resolution in Ukraine to the real needs of the population. Formal setting of international practices of the application of mediation in the specified field does not approve them in the sphere of administrative justice, does not give signs of efficiency and admissibility. It is proved expedient to recognize the dispute settlement procedures involving administrative judges a variety of court mediation procedures and subsequently to separate them from administrative justice.

The purpose of the study is to identify ways to improve the efficiency of the resolution of public law disputes in Ukraine through the use of international experience in this process; to outline a unified concept of reforming the institutional and legal foundations of involving an administrative court judge as a mediator and offer specific recommendations for implementing changes to the legal reality of Ukraine. The main tasks that have determined the substantive components of the study are the following: establishing the nature and determinative features of public litigation, the separation of administrative justice as a way of solving it, identifying mediation as an alternative to judicial consideration of resolving public law disputes, comparing the model of settlement administrative proceedings, not only with traditional mediation, but with modernized understanding of the purpose of the state and justice as part of its key feature, efficiency at present.

In the current research we used both general philosophical and special methods of scientific knowledge such as systematic analysis method, dialectical method, formal-logical method and structural-functional method, as well as a number of empirical methods. The survey results are relevant to domestic legislators and entities engaged in protection of rights and freedoms of an individual and citizen in the field of public administration on the background of updating management trends of democratization of administrative processes in Ukraine. 


\section{REFERENCES}

1. Bryant G. Garth (1992) Power and Legal Artifice: The Federal Class Action Law \& Society Review, 26 (2), pp. 237-272, DOI: 10.2307/ 3053898.

2. G. Richard Shell (1988) The role of public law in private dispute resolution: reflections on Shearson/American express, Inc. V. McMahon. American business law journal, 26 (3): 397-433, DOI: 10.1111/ j.1744-1714.1988.tb01150.x.

3. Kaija Sandra, Reingolds Valerijs (2014) The role of mediation in public and private law in the Republic of Latvia. International Multidisciplinary Scientific Conferences on Social Sciences and Arts (SGEM 2014), Albena. Political sciences, law, finance, economics and tourism, 1: 491-498.

4. Mimoso Maria Joao; Anjos Maria do Rosario (2019) Administrative arbitration in public procurement: a look at Portuguese law, Juridical tribune-tribuna juridical, 9 (1): 196-205.

5. Richard C. Reuben (1997) Public Justice: Toward a State Action Theory of Alternative Dispute Resolution, California Law Review, 85 (3): 577-641, DOI: $10.2307 / 3481153$.

6. Sandra Kaija, Inga Kudeikina (2018) Legal Scope of the Mediation and Problem of Applicability, European Journal of Sustainable Development, 7 (4): 372-380, DOI: 10.14207/ejsd.2018.v7n4p372.

7. Алексеев С.С. Право и управление в социалистическом обществе (общетеоретические вопросы). Советское государство $и$ право. 1973. № 6. С. 13.

8. Білуга С.С. Досудове врегулювання адміністративно-правових спорів: автореф. дис. ... канд. юрид. наук: 12.00.07. Одеса, Національний університет, «Одеська юридична академія». 2015. 22 с. URL: http://dspace.onua.edu.ua/bitstream/handle/11300/1980/\%D0\%91\% D1\%96\%D0\%BB\%D1\%83\%D0\%B3\%D0\%B0\%20\%D0\%A1.\%20\% D0\%A1.pdf?sequence $=1 \&$ isAllowed $=y$.

9. Бортнік О.Г. Мирова угода у цивільному судочинстві : дис. ... канд. юрид. наук : 12.00 .03 / О.Г. Бортнік. Харківський національний ун-т внутрішніх справ. Х., 2007. 227 с.

10. Державне управління в Україні: навчальний посібник. За загальною редакцією В. Б. Авер'янова. К.: НАН України. Інститут держави і права ім. В.М. Корецького, 1999. С. 19.

11.Дзевелюк М.В. Сервісна держава як функціональна модель сучасної держави. Актуальні проблеми держави $i$ права. 2017. Вип. 78. Ст. 60-67. 
12. Єдиний державний реєстр судових рішень. Офіційний вебпортал «Судова влада». URL: http://reyestr.court.gov.ua/

13. Керівні принципи для кращого виконання наявної Рекомендації про альтернативні методи розв'язання спорів між адміністративними органами i приватними сторонами, затверджені Європейською комісією 3 питань ефективності правосуддя 7.12.2007 p., CЕРЕЈ (2007) 15. URL: https://vkksu.gov.ua/userfiles/doc/perelikdokumentiv/ EU_Standarts_book_web-1.pdf.

14.Кодекс адміністративного судочинства України: науковопрактичний коментар / За заг. редакцією Р. О. Куйбіди (видання друге, доповнене). К.: Юстініан, 2009. 976 с.

15.Кодекс адміністративного судочинства: Закон України від 06.07.2005 р. № 2747-IV. Офіиіийнй веб-портал Верховної Ради України. URL: https://zakon.rada.gov.ua/laws/show/2747-15.

16.Конституція України: прийнята на 5 сесії Верховної Ради України 28.06.1996 р. Офіиійний веб-портал Верховної Ради Украӥни. URL: https://zakon.rada.gov.ua/laws/show/254\%D0\%BA/96-\%D0\%B2\% D1\%80.

17. Колясникова Ю.С. Примирительные процедуры в арбитражном процессе : автореф. дис. ... канд. юрид. наук. : спец. 12.00.03«Гражданское право и процесс; хозяйственное право» / Ю.С. Колясникова. Екатеринбург, 2009. 26 с.

18. Крохина Ю. А. Юридический конфликт в финансовой сфере: причины, сущность и процедуры преодоления. Журнал российского права. 2003. № 9. С. 72.

19. Любченко Я.П. Альтернативні способи вирішення правових спорів: теоретико-правовий аспект: автореф. дис. ... канд. юрид. наук: 12.00.01. Харків, Національний юридичний університет імені Ярослава Мудрого. 2018. 22 с. URL: http://nauka.nlu.edu.ua/download/ diss/Lubchenko /d_Lubchenko.pdf

20. Основи адміністративного судочинства та адміністративного права : навч. посіб. / за заг. ред. Р.О. Куйбіди, В.І. Шишкіна. К. : Старий світ, 2006. 256 с.

21. Подковенко Т.О. Медіація як один з альтернативних способів розв'язання юридичних конфліктів. Державо і право. Вип. 45. Ст. 31.

22. Про внесення змін до Господарського процесуального кодексу України, Цивільного процесуального кодексу України, Кодексу адміністративного судочинства України та інших законодавчих актів: Закон України від 03.10.17 р. № 2147-VIII. Офіиіийний веб-портал 
Верховної Ради Украӥни. URL: https://zakon.rada.gov.ua/laws/ show/2147-19.

23. Рекомендация $\mathrm{R}(81) 7$ Комитета Министров государствамчленам относительно путей облегчения доступа к правосудию 14 мая 1981 г. Офіиійний веб-портал Верховної Ради Украӥни. URL: https://zakon.rada.gov.ua/laws/show/994_133.

24. Рекомендація Rec (2001) 9 Комітету Міністрів Ради Свропи державам-членам щодо альтернатив судовому розгляду спорів між адміністративними органами й сторонами - приватними особами, ухвалена Комітетом Міністрів 5 вересня 2001 p. URL: https://vkksu.gov.ua/userfiles/doc/perelik-dokumentiv/EU_Standarts_ book_web-1.pdf.

25. Спектор О.М. Альтернативні способи вирішення цивільноправових спорів: світовий досвід та перспективи застосування у правовій системі України. Київ: Фенікс, 2013. 159 с.

26. Харитонов Є. О., Старцев О. В. Цивільне право України: підручник. вид. 2, перероб. і доп. К.: Істина, 2007. 816 с.

27. Харитонова О. І. Адміністративно-правові відносини (проблеми теоріі): монографія. О.: Юридична література. 2004. 328 с.

28. Чабаненко М.М., Лежнсва Т.М. Правова природа врегулювання спору за участю судді (в контексті структури цивілістичного процесу). Порівняльно-аналітичне право. 2018. № 2. С. 135-137. URL: http://pap.in.ua/2_2018/37.pdf.

29. Шинкар T.I. Застосування медіації в адміністративному судочинстві: вітчизняний та зарубіжний досвід: автореф. дис. ... канд. юрид. наук: 12.00.07. Львів, Національний університет, «Львівська політехніка». 2017. 24 с. URL: http://lp.edu.ua/sites/default/files/ dissertation/2018/8401/aref_shynkar_1.pdf.

\section{Information about the author:} Kivalov S. V.,

Doctor of Law, Professor, National University "Odessa Law Academy" 2, Academychna str., Odessa, 65009, Ukraine 


\section{THE GENESIS OF LOCAL SELF-GOVERNMENT IN UKRAINE. URGENT ISSUES OF LEGAL SUPPORT OF LOCAL SELF-GOVERNMENT}

\section{Panchyshyn R. I.}

\section{INTRODUCTION}

The reform of local self-government is ongoing today in Ukraine, its tasks in accordance with the Concept of the Reform of Local SelfGovernment and Territorial Organization of Power in Ukraine approved by the Order of the Cabinet of Ministers of Ukraine dated April 01, 2014 No. $333^{1}$, are to form effective local self-government and territorial organization of power, to create and support an adequate living environment for citizens, to provide high-quality and accessible public services, to establish institutions of direct democracy, etc.

To achieve those objectives, in particular, proper legislative support for the process of reforming local self-government and formation of necessary organizational conditions are of particular importance. Significant steps aimed at achieving the goal of legislative support for the process of reforming local self-government have been implemented, in particular, the Law of Ukraine "On Voluntary Association of Territorial Communities"2 is adopted, amendments and additions to a number of legislative acts, etc. are made. Meanwhile, the process of formalization of constitutional and legal regulation of the process of implementation of local self-government reform in Ukraine is ongoing.

In order to determine the further prospects for development of legislation in this field, it is necessary to conduct a study of the current state of legal support of local self-government reform in Ukraine, to reveal the shortcomings and gaps of the relevant legislation and to develop proposals for further improvement of legislation in this field.

${ }^{1}$ On Approval of the Concept of the Reform of Local Self-Government and Territorial Organization of Power in Ukraine. Order of the Cabinet of Ministers of Ukraine dated April 01, 2014 No. 333-r. [Electronic resource]. - Access mode: http://zakon3.rada.gov.ua/laws/show/ 333-2014-\%D1\%80. (in Ukrainian)

${ }^{2}$ On Voluntary Association of Territorial Communities. The Law of Ukraine dated February 05, 2015 No. 157-VIII. [Electronic resource]. - Access mode: http://zakon3.rada.gov.ua/laws/ show/157-19. (in Ukrainian) 


\section{The importance of the European legal acts in the field of regulation of the local self-government for successful implementation of the constitutional reform in Ukraine}

At the current stage of realization of the local self-government reform in Ukraine, European law is of particular relevance.

Thus, one of the first international instruments in the European transnational space has become the European Outline Convention on Transfrontier Co-operation between Territorial Communities or Authorities $^{3}$. This Convention imposes on the contracting parties the obligation to maintain and promote cross-border co-operation between territorial communities and authority under the jurisdiction of which the concerned community is and the territorial communities or authorities being under the jurisdiction of the other contracting parties.

The main purpose of the European Outline Convention on Transfrontier Cooperation between Territorial Communities or Authorities is, with due regard to the respective constitutional provisions of each party, to facilitate the conclusion of agreements and coming to understanding possibly needed for it.

Another international act is the European Urban Charter which holds the contracting parties responsible for building a system of governance that takes account of the new demands of democracy, in particular of its dimension of city people and urban territory residents participation in addressing and making decisions on issues of local value ${ }^{4}$.

The European Urban Charter is aimed, first and foremost, at creating conditions for equal development of urban territorial communities, eliminating social stratification within such communities etc.

The Framework Convention for Protection of National Minorities is equally important for regulation of the status of territorial community at international level. In particular, the content of the provisions of this Convention implies that the contracting parties undertake to guarantee to persons belonging to national minorities the right of equality under the law and the right to equal protection by the law. In this regard, any discrimination based on belonging to a national minority is prohibited ${ }^{5}$.

${ }^{3}$ European Outline Convention on Transfrontier Cooperation between Territorial Communities or Authorities. International Document dated May 21, 1980. [Electronic resource]. - Access mode: http://zakon3.rada.gov.ua/laws/show/995_106.

${ }^{4}$ European Urban Charter. International Document, 1992. [Electronic resource]. - Access mode: http://www.slg-coe.org.ua/wp-content/uploads/2015/05/Principle-9.-European-chart.pdf.

${ }^{5}$ Framework Convention for the Protection of National Minorities. International Document dated February 01, 1995. [Electronic resource]. - Access mode: http://zakon2.rada.gov.ua/ laws/show/995_055. 
One of the fundamental international legal acts in the field of determining the status of a territorial community (united territorial community) is the European Charter of Local Self-Government which at the international level has confirmed the status of a territorial community, with fixation of its right to implement local self-government, and has determined the basic principles for formation of elected local selfgovernment bodies and fulfillment of their functions by those.

While exploring the importance of the European Charter of Local SelfGovernment $^{6}$ for the formation and development of a territorial community (united territorial community) in Ukraine, it is worth noting that in the European Community this document has played a decisive role in promoting the democratic foundations of realization of local selfgovernment.

In particular, foreign scientists note that the following axiological principles have been embodied in the European Charter of Local SelfGovernment: the local authorities are one of the main pillars of any democratic regime; presence of local authorities with real responsibilities ensures more effective realization of public government, public authorities are brought closer to citizens; safeguarding and strengthening of local self-government in different European countries is an important contribution to building a democratic Europe with dominating principles of democracy and decentralization of power; existence of local authority is recognized, its democratic embodiment are the elected representative decision-making bodies having a high degree of autonomy as to their responsibilities, the ways and means by which the responsibilities are fulfilled, and provided with the resources necessary to fulfill those responsibilities ${ }^{7}$.

Ukraine has ratified the European Charter of Local Self-Government in $1997^{8}$, without any provisions and reservations, thus having become a full member of this international instrument.

In 2009, the Additional Protocol to the European Charter of Local SelfGovernment on the Right to Participate in the Affairs of a Local Self-

${ }^{6}$ European Charter of Local Self-Government. International Document dated October 15, 1985. [Electronic resource]. - Access mode: http://zakon5.rada.gov.ua/laws/show/994_036.

${ }^{7}$ Himsworth C. Treaty-Making For Standards Of Local Government: The European Charter of Local Self-Government and its Possible Application Beyond Europe / University of Edinburgh School of Law Working. 2011. № 2011/24. 17 p. P. 4.

${ }^{8}$ On Ratification of the European Charter of Local Self-Government. Law of Ukraine dated July 15, 1997 No. 452/97-VR. [Electronic resource]. - Access mode: http://zakon3.rada.gov.ua/ laws/show/452/97-\%D0\%B2\%D1\%80. (in Ukrainian). 
Government Authority was adopted ${ }^{9}$, this was ratified by Ukraine as late as $2014^{10}$. The Additional Protocol obliges the participants of the European Charter of Local Self-Government to ensure that national legislation has to make provisions for means promoting realization of the rights of local self-government bodies.

In this context, it is likely that such means as the right of voters to recall an elected local self-government person, or to early terminate his/her authorities.

Considering the fundamental importance of the European Charter of Local Self-Government for the development of local democracy in European countries, the Council of Europe periodically monitors the implementation of the Charter norms in the national legislation of the contracting States and provides recommendations on the further implementation of the relevant provisions of the Charter.

In such a way, on the basis of monitoring of the European countries adherence to the European Charter of Local Self-Government, it is pointed out that the adoption of the Charter and its ratification in many countries have led to reformation of local self-government accompanied by updating legislation in the sphere of local democracy. For some countries, the Charter and its principles have served as the basis for building a new system of local self-government. Along with that, the results of monitoring show that local self-government in many Member States remains unstable, in particular due to a lack of efficient legislative framework and slow reformation of administrative practice ${ }^{11}$.

Thus, most European countries have encountered some difficulties in implementing the principles of the European Charter of Local SelfGovernment, in particular with regard to reforming their own local selfgovernment system and bringing national legislation in line with European standards. Therefore, it is not surprising that similar problems are also present in our State in the process of implementing the reform for decentralization of power.

${ }^{9}$ Additional Protocol to the European Charter of Local Self-Government on the Right to Participate in the Affairs of a Local Self-Government Authority. International Document dated November 16, 2009. [Electronic resource]. - Access mode: http://zakon5.rada.gov.ua/laws/show/ 994_b49/paran2\#n2.

${ }^{10}$ On Ratification of the Additional Protocol to the European Charter of Local SelfGovernment on the Right to Participate in the Affairs of a Local Self-Government Authority. The Law of Ukraine dated September 02, 2014 No. 1664-VII. [Electronic resource]. - Access mode: http://zakon5.rada.gov.ua/laws/show/1664-18. (in Ukrainian)

${ }^{11}$ Kirchmair L. International Law and Public Administration: The European Charter of Local Self-Government / European treaty series. 2015. No. 122. P. 124-135. 
In order to facilitate the further implementation of local selfgovernment reform and to ensure the implementation of the European standards of local democracy, the Parliamentary Assembly of the Council of Europe is developing recommendations, in particular, in 2005, the Resolution No. 1466 (2005) "On Fulfillment of Duties and Obligations by Ukraine" is adopted, with one of the clauses pointing on continuation of the reform of local self-government to implement the provisions of the European Charter of Local Self-Government ${ }^{12}$.

Another important document was adopted by the Council of Europe in 2005 - the Recommendation No. R (2005) to Member States on the practice of border and inter-territorial cooperation of territorial communities ${ }^{13}$.

\section{The current state of legal regulation of the process of reforming local self-government in Ukraine}

The fundamental European principles of local democracy have been embodied in the constitutional legislation of Ukraine.

Thus, the Constitution of Ukraine enshrines the right of the territorial community to realize local self-administration; the principles of formation and types of representative bodies of local self-government are determined; the principles of interaction between the local self-government bodies and public authorities, including local executive bodies, etc. In addition, at the level of the Constitution of Ukraine, the guaranteed right of the territorial community to independently manage communal property resources ${ }^{14}$ is fixed.

In characterizing the constitutional foundations of ensuring the process of implementation of the local self-government reform it should be noted that in most European countries local self-administration is guaranteed at the constitutional level.

Some scientists at comparing the constitutions of the most countries in the world point out that the basic provisions enshrined in those relate to the functioning of local self-government, namely: the basic principles of the

${ }^{12}$ On Fulfillment of Duties and Obligations by Ukraine. Resolution 1466 (2005) of the Parliamentary Assembly of the Council of Europe dated October 5, 2005. [Electronic resource]. Access mode: http://zakon3.rada.gov.ua/laws/show/994_611.

${ }^{13}$ On Good Practices in and Reducing Obstacles to Transfrontier and Interterritorial Cooperation between Territorial Communities or Authorities. Recommendation No. R (2005) 2 of the Committee of Ministers of the Council of Europe to Member States dated January 19, 2005. [Electronic resource]. - Access mode: http://zakon3.rada.gov.ua/laws/show/994_667.

${ }^{14}$ Constitution of Ukraine. The Law of Ukraine of 28.06.1996 No. 254k/96-VR. [Electronic resource]. - Access mode: http://zakon3.rada.gov.ua/laws/show/254\%D0\%BA/96-\%D0\%B2\% D1\%80. (in Ukrainian) 
organization of local self-government; principles of administrative-territorial division; organizational forms of realization of local self-administration, fundamentals of its competence, internal structure; the role and the place of local authorities in the political system of society; administrative supervision; guarantees for the local self-government (constitutional, judicial, legislative, financial etc. $)^{15}$.

The constitutional principles of the local self-government are specified and detailed in a number of laws and by-laws.

So, the legal basis for the status of a united territorial community is provided by the laws of Ukraine "On Local Self-Government in Ukraine" ${ }^{16}$, "On Service in Local Self-Government Bodies"17, "On Public SelfOrganization Bodies”"18, “On Cooperation of Territorial Communities”, "On Voluntary Association of Territorial Communities", "On Principles of State Regional Policy”" "On Local Elections”,21, and so forth.

First of all, it should be emphasized that the legislation of Ukraine in the field under investigation has been substantially updated in connection with the implementation of the decentralization of power reform by adopting new or making amendments to existing laws.

So, in 2015, the Law of Ukraine "On Principles of State Regional Policy" was adopted, this defined the basic principles of formation and implementation of the State regional policy. The State regional policy in this Law is defined as a system of goals, measures, means and coordinated actions of central and local executive bodies, local selfgovernment bodies and officials of those to ensure high quality of life of people through the whole territory of Ukraine, with account of natural,

${ }^{15}$ Petryshyna M.O., Petryshyn O.O. International legal standards in the field of local selfgovernment. Kh.: Pravo, 2016. 44 p. P. 18. (in Ukrainian)

${ }^{16}$ On Local Self-Government in Ukraine. The Law of Ukraine dated May 21, 1997 No. 280/97. [Electronic resource]. - Access mode: http://zakon3.rada.gov.ua/laws/show/280/97\%D0\%B2\%D1\%80. (in Ukrainian)

${ }^{17}$ On Service in Local Self-Government Bodies. The Law of Ukraine dated June 07, 2001 No. 2493-III. [Electronic resource]. - Access mode: http://zakon5.rada.gov.ua/laws/show/249314. (in Ukrainian)

${ }^{18}$ On Public Self-Organization Bodies. The Law of Ukraine dated July 11, 2001 No. 2625-III. [Electronic resource]. - Access mode: http://zakon2.rada.gov.ua/laws/show/2625-14. (in Ukrainian)

${ }^{19}$ On Cooperation of Territorial Communities. The Law of Ukraine dated June 17, 2014 No. 1508-VII. [Electronic resource]. - Access mode: http://zakon3.rada.gov.ua/laws/show/ 1508-18. (in Ukrainian)

${ }^{20}$ On the Principles of State Regional Policy. The Law of Ukraine dated February 05, 2015 No. 156-VIII. [Electronic resource]. - Access mode: http://zakon3.rada.gov.ua/laws/show/156-19. (in Ukrainian)

${ }^{21}$ On Local Elections. The Law of Ukraine dated July 14, 2015 No. 595-VIII. [Electronic resource]. - Access mode: http://zakon5.rada.gov.ua/laws/show/595-19. (in Ukrainian) 
historical, environmental, economic, geographical, demographic and other peculiarities of the regions, their ethnic and cultural identity ${ }^{20}$.

Adoption of this law is of large regulatory and strategic importance for harmonization of the legal relationships that are formed in the field of formation and implementation of regional policy, in particular, this Law identifies the sources of funding for the measures aimed at the implementation of the regional policy, the entities responsible for this direction of the State policy, monitoring of the state of implementation of regional policy is introduced.

The key laws that have determined the status of a united territorial community in Ukraine are the laws "On Local Self-Government in Ukraine”, "On Voluntary Association of Territorial Communities", "On Local Elections".

So, the Law of Ukraine "On Local Self-Government in Ukraine"16 has been adopted as far back as 1997, however, since then it has been amended and supplemented, with amendments mainly aimed at empowering the territorial community and its representative bodies. In particular, the powers of local self-government bodies are supplemented by the ones as the right to: reorganization or liquidation of educational establishments of communal ownership that is carried out by decision of the local council ${ }^{22}$, formation and maintenance of the register of territorial community in accordance with the law ${ }^{23}$, exercising the powers in the area of use of urban passenger transport ${ }^{24}$, etc.

In Art. 6 of the Law of Ukraine "On Local Self-Government in Ukraine» ${ }^{\text {, }}$, the guaranteed right of territorial communities to voluntarily unite in one rural, settlement, urban territorial community, to form joint bodies of local self-government and to elect respectively a village, settlement, city head is captured. The law also gives the territorial community the right to leave the association.

The procedure for association of a territorial community and for withdrawal from the association is determined by the Law of Ukraine "On Voluntary Association of Territorial Communities", This Law also

${ }^{22}$ On Amendments and Declaring Lapsed Some Legislative Acts of Ukraine. The Law of Ukraine dated December 28, 2014 No. 76-VIII. [Electronic resource]. - Access mode: http://zakon2.rada.gov.ua/laws/show/76-19/paran130\#n130. (in Ukrainian)

${ }^{23}$ On Amendments to Some Legislative Acts of Ukraine on Extending the Authorities of Local Self-Government Bodies and Optimizing the Provision of Administrative Services. The Law of Ukraine dated December 10, 2015 No. 888-VIII. [Electronic resource]. - Access mode: http://zakon2.rada.gov.ua/laws/show/888-19/paran44\#n44. (in Ukrainian)

${ }^{24}$ On Amendments to Some Legislative Acts of Ukraine on the Implementation of the Automated System of Accounting for Fare Payment in Urban Passenger Transport. The Law of Ukraine dated January 17, 2017 No. 1812- 
regulates the principles, terms for association of territorial community; determines the directions and means of State support of a viable united territorial community, etc.

Formation of joint bodies of local self-government by a united territorial community is carried out in accordance with the procedure prescribed by the Law of Ukraine "On Local Elections"21.

The electoral legislation, in particular the one regulating the procedure for organizing and holding elections in the united territorial communities, is represented by numerous normative and legal acts the adoption of which has been often accompanied by inconsistency caused by lack of a unified conceptual vision by the legislator of how the process of holding elections in united territorial communities should be organized.

Thus, of large importance for forming a new local self-government system is the Law of Ukraine "On Local Elections",21, with enactment of which the Law of Ukraine "On election of deputies of the Verkhovna Rada of the Autonomous Republic of Crimea, local councils and village, settlement, city mayors" ${ }^{25}$ has become void. The new Law has introduced some significant innovations, in particular regarding the differentiation of the way of organizing and holding elections depending on the size of population of the respective territorial (united territorial) community, as well as the requirements for lists of political parties, etc.

Along with that, some scientists soundly point out that introduction into the practice of formation of local self-government bodies in Ukraine of a proportional electoral system does not completely meet the needs of territorial communities - residents of villages, towns and cities. Their interests will not always be properly represented and protected in district and regional councils. While the importance of local elections is determined, first of all, by identification of social, economic and other problems, interests, needs of citizens in a certain administrative-territorial unit and by development of preconditions to resolve those by the local self-government bodies ${ }^{26}$.

\footnotetext{
${ }^{25}$ On election of deputies of the Verkhovna Rada of the Autonomous Republic of Crimea, local councils and village, settlement, city mayors. The Law of Ukraine dated July 10, 2010 No 2487-VI. [Electronic resource]. - Access mode: http://zakon3.rada.gov.ua/laws/show/2487-17. (in Ukrainian)

${ }^{26}$ Martseliak O.V. Electoral system in Ukraine: search for the optimal model // Bulletin of the Kharkiv National University of Internal Affairs. - 2007. - No. 37. - P. 83-84. (in Ukrainian)
} 


\section{Some problems of legal regulation of the process of reforming local self-government and ways for resolving those}

At determining the state of constitutional and legal support for the implementation of local self-government reform it should be noted that the process of forming united territorial communities and reorganization of local self-government bodies is the subject of numerous scientific discussions today.

So, V.V. Tolkovanov soundly points out that the reform of local selfgovernment is impossible without qualitative changes in the legal field, modernization of current legislation in force. The scientist believes that as a matter of priority Constitution of Ukraine should be amended, in particular in regard to formation of executive bodies of regional and district councils and to division of powers between those; new version of laws on local self-government, service in local self-government bodies, on local State administrations is developed and adopted, other legislative and regulatory legal acts on introduction of the mechanism of direct people power, improvement of legal regulation of procedures of holding general meetings of citizens at their place of residence and establishment of additional guarantees for activity of public self-organization bodies etc ${ }^{27}$..

L.A. Belukha believes that in order to increase the effectiveness of local self-government reform it is necessary to ensure: reviewing and formulating a prospective schedule for integration of territorial communities with maximum account of geographical, cultural, ethnic and other specificities of communities; information and clarification support for the process of integration of territorial communities; conducting training seminars for local self-government officials and the public on various aspects of the reform ${ }^{28}$.

Electoral law has a significant impact on the process of reforming local self-government in Ukraine, since its shortcomings substantially affect the process of calling and holding the first elections in the united territorial communities.

In particular, the lack of political will of the Central Election Commission, the untimely receipt of requests from State administrations and proper methodological support of territorial election commissions by the

\footnotetext{
${ }^{27}$ Tolkovanov V.V. Priorities and approaches to modernization of local self-government at the present stage: domestic and foreign experience // The theory and practice of public administration and local self-government. - 2017. - No. 1. - P. 6 - 7. [Electronic resource]. Access mode: http://el-zbirn-du.at.ua/2017_1/28.pdf. (in Ukrainian)

${ }^{28}$ Belukha L.A. The concept of territorial community and capable territorial community / Theory and practice of public administration. - 2017. - No. 1(56). - P. 5. [Electronic resource]. Access mode: http://www.kbuapa.kharkov.ua/e-book/tpdu/2017-1/doc/3/02.pdf. (in Ukrainian)
} 
central one are a major problem in calling and holding elections in united territorial communities.

According to Part 8 of Art. 7 of the Law of Ukraine "On Voluntary Association of Territorial Communities", the first elections of deputies of rural, settlement, city councils of united territorial communities and respective rural, settlement, city heads are scheduled by the Central Election Commission at respective appeals of the Council of Ministers of the Autonomous Republic of Crimea, regional State administrations on calling the first local elections in accordance with the procedure prescribed by law ${ }^{2}$.

At that, in some united communities a situation of untimely receipt of requests for the first local elections from regional State administrations has taken place. For example, in 2016 such requests on elections were not received in 300 united territorial communities, and as a result the Central Election Commission did not call the elections in such communities.

Along with that, as it isindicated in the official response of the Ministry of Regional Development, Construction and Housing and Communal Services of Ukraine to the Central Election Commission, absence of decisions of the Commission on calling the first elections in the united territorial communities, in particular the ones formed around the cities of regional significance, adversely affects the further initiation of association and, accordingly, use of the State budget funds for holding the first local elections there ${ }^{29}$. The Ministry's report also states that the Central Election Commission, without any reason, has independently determined that it schedules the elections in the communities only twice a year - in April and October, and, as an exception, in December as well ${ }^{30}$ (P. 2).

At that, the Resolution of the Central Election Commission "On Procedure for calling the First Elections of Deputies of Rural, Settlement, City Councils of United Territorial Communities and the respective Rural, Settlement, City Mayors” defines an exhaustive list of grounds on which the commission may decide to refuse holding such elections.

In addition to the problematic aspects discussed above, the issues of establishing boundaries of electoral constituencies in accordance with the requirements of current legislation remain unresolved. So, the Committee of Voters of Ukraine on this issue has noted that under current conditions

\footnotetext{
${ }^{29}$ Stop the practice of finding reasons and take legal opportunities - Minregion to the CEC: Decentralization. - 2017. - [Electronic resource]. - Access mode: http://decentralization.gov.ua/ news/7380. (in Ukrainian)

${ }^{30}$ First Elections in United Communities. An Analytical Report. Committee of Voters of Ukraine. Kyiv. - 2017. - 45 p. - P. 2. (in Ukrainian)
} 
it is practically impossible to ensure simultaneous keeping to the norms of the Law of Ukraine "On Local Elections" regarding compliance with administrative boundaries and equality of voters in districts because of the electoral systems used at the local elections and the imperfection of administrative-territorial structure of Ukraine $^{30}$ (P. 2).

The problematic issues discussed above that arise at organizing and holding elections in a united territorial community are mainly caused by imperfection of national legislation in this area.

Following the first local elections in 2015 in the United Territorial Communities it was found out that the current legislation had a number of gaps and shortcomings that in practice give rise to particular problems. Therefore, in order to close those gaps, the Verkhovna Rada of Ukraine within the period of the years 2016-2018 has developed and adopted some draft laws amending the electoral legislation of Ukraine.

According to some scientists, adoption by the Verkhovna Rada of Ukraine of draft laws with register numbers No. 4772 and No. 5520 (laws currently in force) was of particular importance for implementation of the decentralization reform, and this significantly influenced the tactics of reforming the administrative and territorial system as a component of the reform of local self-government and territorial organization of power ${ }^{31}$.

So, the Law of Ukraine "On Amendments to Some Legislative Acts of Ukraine (on voluntary association of territorial communities)" (the draft law had the register number No. 4772) ${ }^{32}$, was adopted on February 9, 2017 and signed by the President of Ukraine on March 17, 2017.

This law introduces amendment and additions to the laws of Ukraine “On Voluntary Association of Territorial Communities" and "On Local Elections" in the part related to the accession of territorial communities to an already united community. In particular, due to adoption of this Law the problem of ensuring the participation of the members of the affiliated territorial community in formation of representative bodies of local selfgovernment has been partially resolved by introducing additional elections in the united territorial communities.

It is stipulated that the by-elections are to be called not later than in 70 days before the day of elections, and the election process shall be started in 50 days before the day of the by-elections. The total composition of the

${ }^{31}$ Decentralization - 2017. The reform will go on. - 2017. - [Electronic resource]. - Access mode: https://sorada.gov.ua/actual/18489-detsentralizatsija-2017-reforma-bude-prodovzhuvatys.html. (in Ukrainian)

${ }^{32}$ On Amendments to Some Legislative Acts of Ukraine (on Voluntary Association of Territorial Communities). The Law of Ukraine dated June 03, 2016. No. 4772. [Electronic resource]. - Access mode: http://w1.c1.rada.gov.ua/pls/zweb2/webproc4_1?pf3511=59314. (in Ukrainian) 
local council is at that increased beyond the determined by the part three of this article due to holding additional elections to the village, settlement, city council additionally by the number of newly formed single-mandate constituencies that is defined as the ratio of voters of territorial communities that have joined, to the number of voters of territorial community they have joined to, multiplied by the general composition of the council determined by the part three of this article, though not less than the number of territorial communities that have joined up ${ }^{33}$.

Along with that, the draft law does not solve the problem of ensuring the participation of members of the territorial community that has joined up in formation in the united territorial community of the chief, of village, settlement, city mayor, if they have already been elected, and accordingly the procedure for termination of powers of the heads of the territorial community that has decided to join.

The Law of Ukraine "On Amendments to Some Legislative Acts of Ukraine on the Features of Voluntary Association of Territorial Communities Located in the Territories of Adjacent Areas ${ }^{33}$, was adopted on March 14, 2017 and returned with the signature of the President of Ukraine on April 3, 2017. This Law is aimed at partially solving the problem of determining the boundaries of constituencies at organizing and holding the first elections in a united territorial community.

The most debatable is the Law of Ukraine "On Amendments to the Law of Ukraine "On Voluntary Association of Territorial Communities" as to voluntary accession of territorial communities of villages, settlements to territorial communities of cities of regional significance"34 adopted on April 3, 2018 and signed by the President of Ukraine on May 4, 2018. In accordance with this Law, it is proposed to declare as viable united territorial communities for the cases provided for in the Articles $8^{1}-8^{3}$ of the Law the territorial communities of cities Republic significance of the Autonomous Republic of Crimea, of regional significance. In other words, the drafters of the Law propose to automatically equate the territorial

\footnotetext{
${ }^{33}$ On Amendments to Some Legislative Acts of Ukraine on the Features of Voluntary Association of Territorial Communities Located in the Territories of Adjacent Areas. The Law of Ukraine dated December 09, 2016 No. 5520. [Electronic resource]. - Access mode: http://w1.c1.rada.gov.ua/pls/zweb2/webproc4_1?pf3511=60681. (in Ukrainian)

${ }^{34}$ On Amendments to the Law of Ukraine "On Voluntary Association of Territorial Communities" on the voluntary accession of territorial communities of villages, settlements to territorial communities of cities of regional significance. The Law of Ukraine dated April 03, 2018 No. 2379-VIII. [Electronic resource]. - Access mode: http://w1.c1.rada.gov.ua/pls/zweb2/ webproc4_1?pf3511=61814. (in Ukrainian)
} 
communities of the cities of regional and republican significance to viable united territorial communities.

Along with that, the Opinion of the Scientific and Expert Administration Head Office to the draft of this Law clearly indicates its inconsistency with the basic constitutional principles of territorial organization and local selfgovernment, that is, in fact, it focused on the unconstitutionality of the provisions of this $\mathrm{Law}^{35}$.

It should be noted that the provisions of the Law of Ukraine "On Amendments to the Law of Ukraine "On Voluntary Association of Territorial Communities" as to voluntary accession of territorial communities of villages, settlements to territorial communities of cities of regional significance" make evidence of the following:

1) since one of the principles of association of territorial communities is the principle of voluntariness, adoption of this Law leads to violation of this principle. In support of this conclusion, it should be noted that the territorial communities of cities of regional and republican significance, are usually large and respectively vitally capable and do not need to go into association, therefore, the way chosen in this Law to "encourage" such communities to association with small villages and settlements will violate the principle of voluntariness;

2) the mechanism of association of territorial communities introduced in the Law is such that it does not meet the constitutional norms, since the system of united territorial communities and their bodies is to be built according to the system of administrative and territorial organization that should include the villages (several villages), settlements, cities, districts and regions that are to be administrated by the respective local selfgovernment bodies and the local executive authorities;

3) the legislator has empowered the Cabinet of Ministers of Ukraine to act on behalf of the State in the process of declaring the united territorial communities viable and to make respective administrative decisions on the normative fixation of such declaration in the form of a by-law, though in the Law under consideration such powers are transferred to the Verkhovna Rada of Ukraine, and this is in contradiction with the constitutional principle of distribution of powers.

\footnotetext{
${ }^{35}$ Opinion of the Head Scientific and Expert Office on the Draft Law «On Amendments to the Law of Ukraine "On Voluntary Association of Territorial Communities" on the voluntary accession of territorial communities of villages, settlements to territorial communities of cities of regional significance» dated June 06, 2017. [Electronic resource]. - Access mode: http://w1.c1.rada.gov.ua/ pls/zweb2/webproc4_1?pf3511=61814. (in Ukrainian)
} 
Therefore, the Law of Ukraine "On Amendments to the Law of Ukraine "On Voluntary Association of Territorial Communities" as to voluntary accession of territorial communities of villages, settlements to territorial communities of cities of regional significance" is to be be declared unconstitutional on the grounds stated above.

In view of the aforementioned, an appeal is directed to the Constitutional Court of Ukraine under Articles 8 and 55 of the Constitution of Ukraine regarding the unconstitutionality of the Draft Law on Amendments to the Law of Ukraine "On Voluntary Association of Territorial Communities" as to voluntary accession of territorial communities of villages, settlements to territorial communities of cities of regional significance” as of May 18, 2017 under input number No. 6466, adopted and approved on April 03, 2018 in violation of the Law of Ukraine "On voluntary association of territorial communities", Articles 24, 71, 141 of the Constitution of Ukraine, the Law of Ukraine "On Local Elections", the requirements of the Art. 90 of the Law of Ukraine "On Regulations of the Verkhovna Rada of Ukraine”.

\section{CONCLUSIONS}

Thus, as a result of the study, we can draw the following conclusions.

1. The last phase of the reform of local self-government has begun within the framework of the constitutional reform of decentralization of power in 2015 and is still ongoing. The procedure for association of territorial community and for formation of local self-government bodies of the united territorial community is finally settled during this period. Thus, the State, in an effort to strengthen the financial and institutional viability of territorial community, has significantly expanded the powers of the united territorial communities at the local level. However, for the final legislative formulation of the results of the reform it is necessary to make respective amendments to the Constitution of Ukraine, to develop specific institutional and organizational measures.

2. The actual problems of implementation of the local self-government reform are: 1) some procedures and stages of implementation of the reform (the procedure for holding local referendums, clear timing of scheduling the first, intermediate local elections, etc.) are not regulated; 2) lack of proper organizational conditions for further implementation of the reform (no register of agreements on cooperation of territorial communities is created); 3) the disproportionality of the allocated funds and the financial burden laid upon the territorial communities to maintain territories, and so on.

2. In order to further improve the legislation in the field of regulation of association of territorial communities it is necessary: 1) to enshrine in the 
Laws of Ukraine "On Voluntary Association of Territorial Communities" and "On local elections" that in a territorial community having joined an associated community the powers of the chief and, accordingly, the village, settlement, city mayor shall be terminated from the instant of holding additional elections in such a community to the respective local council and the beginning of the powers of its newly elected members; 2) To declare unconstitutional the Law of Ukraine "On Amendments to the Law of Ukraine "On Voluntary Association of Territorial Communities" as to voluntary accession of territorial communities of villages, settlements to territorial communities of cities of regional significance"; 3) to adopt the Law of Ukraine "On Local Initiatives" that is to make it possible to unify the procedure of submission of proposals for association by the members of territorial community under the procedure of local initiative.

\section{SUMMARY}

The monograph analyzes the current state of legal regulation of implementation of the local self-government reform. The author reviews the European legislation and sets out its importance for the implementation of the local self-government reform in Ukraine. Particular attention is given to the study of electoral law. In the context of the problem of the ordering and holding the first and additional elections in the united territorial communities, as a prerequisite for successful implementation of the local self-government reform, proposals for improvement of the law on local elections are developed. On the basis of the analysis of constitutional legislation in this field carried out, a number of gaps and shortcomings were identified. In particular, it is concluded that some legislative acts that fix the recognition of the capacity of some territorial communities are unconstitutional. Proposals for further development of legislation in the field of regulation of implementation of the local self-government reform in Ukraine are substantiated.

\section{REFERENCES}

1. On Approval of the Concept of the Reform of Local SelfGovernment and Territorial Organization of Power in Ukraine. Order of the Cabinet of Ministers of Ukraine dated April 01, 2014 No. 333-r. [Electronic resource]. - Access mode: http://zakon3.rada.gov.ua/laws/ show/333-2014-\%D1\%80. (in Ukrainian)

2. On Voluntary Association of Territorial Communities. The Law of Ukraine dated February 05, 2015 No. 157-VIII. [Electronic resource]. Access mode: http://zakon3.rada.gov.ua/laws/show/157-19. (in Ukrainian) 
3. European Outline Convention on Transfrontier Cooperation between Territorial Communities or Authorities. International Document dated May 21, 1980. [Electronic resource]. - Access mode: http://zakon3.rada.gov.ua/laws/show/995_106.

4. European Urban Charter. International Document, 1992. [Electronic resource]. - Access mode: http://www.slg-coe.org.ua/wp-content/uploads/ 2015/05/Principle-9.-European-chart.pdf.

5. Framework Convention for the Protection of National Minorities. International Document dated February 01, 1995. [Electronic resource]. Access mode: http://zakon2.rada.gov.ua/laws/show/995_055.

6. European Charter of Local Self-Government. International Document dated October 15, 1985. [Electronic resource]. - Access mode: http://zakon5.rada.gov.ua/laws/show/994_036.

7. Himsworth C. Treaty-Making For Standards Of Local Government: The European Charter of Local Self-Government and its Possible Application Beyond Europe / University of Edinburgh School of Law Working. 2011. № 2011/24. 17 p.

8. On the Ratification of the European Charter of Local SelfGovernment. Law of Ukraine dated July 15, 1997 No. 452/97-VR. [Electronic resource]. - Access mode: http://zakon3.rada.gov.ua/laws/ show/452/97-\%D0\%B2\%D1\%80. (in Ukrainian)

9. Additional Protocol to the European Charter of Local SelfGovernment on the Right to Participate in the Affairs of a Local SelfGovernment Authority. International Document dated November 16, 2009. [Electronic resource]. - Access mode: http://zakon5.rada.gov.ua/laws/ show/994_b49/paran2\#n2.

10. On Ratification of the Additional Protocol to the European Charter of Local Self-Government on the Right to Participate in the Affairs of a Local Self-Government Authority. The Law of Ukraine dated September 02, 2014 No. 1664-VII. [Electronic resource]. - Access mode: http://zakon5.rada.gov.ua/laws/show/1664-18. (in Ukrainian)

11. Kirchmair L. International Law and Public Administration: The European Charter of Local Self-Government / European treaty series. 2015. No. 122. P. 124-135.

12. On Fulfillment of Duties and Obligations by Ukraine. Resolution 1466 (2005) of the Parliamentary Assembly of the Council of Europe dated October 5, 2005. [Electronic resource]. - Access mode: http://zakon3.rada.gov.ua/laws/show/994_611.

13. On Good Practices in and Reducing Obstacles to Transfrontier and Interterritorial Cooperation between Territorial Communities or 
Authorities. Recommendation No. R (2005) 2 of the Committee of Ministers of the Council of Europe to Member States dated January 19, 2005. [Electronic resource]. - Access mode: http://zakon3.rada.gov.ua/ laws/show/994_667.

14. Constitution of Ukraine. The Law of Ukraine of 28.06.1996 No. 254k/96-VR. [Electronic resource]. - Access mode: http://zakon3.rada. gov.ua/laws/show/254\%D0\%BA/96-\%D0\%B2\%D1\%80. (in Ukrainian)

15. Petryshyna M.O., Petryshyn O.O. International legal standards in the field of local self-government. Kh.: Pravo, 2016. 44 p. (in Ukrainian)

16. On Local Self-Government in Ukraine. The Law of Ukraine dated May 21, 1997 No. 280/97. [Electronic resource]. - Access mode: http://zakon3.rada.gov.ua/laws/show/280/97-\%D0\%B2\%D1\%80. (in Ukrainian)

17. On Service in Local Self-Government Bodies. The Law of Ukraine dated June 07, 2001 No. 2493-III. [Electronic resource]. - Access mode: http://zakon5.rada.gov.ua/laws/show/2493-14. (in Ukrainian)

18. On Public Self-Organization Bodies. The Law of Ukraine dated July 11, 2001 No. 2625-III. [Electronic resource]. - Access mode: http://zakon2.rada.gov.ua/laws/show/2625-14. (in Ukrainian)

19. On Cooperation of Territorial Communities. The Law of Ukraine dated June 17, 2014 No. 1508-VII. [Electronic resource]. - Access mode: http://zakon3.rada.gov.ua/laws/show/1508-18. (in Ukrainian)

20. On Principles of State Regional Policy. The Law of Ukraine dated February 05, 2015 No. 156-VIII. [Electronic resource]. - Access mode: http://zakon3.rada.gov.ua/laws/show/156-19. (in Ukrainian)

21. On Local Elections. The Law of Ukraine dated July 14, 2015 No. 595-VIII. [Electronic resource]. - Access mode: http://zakon5.rada.gov.ua/laws/show/595-19. (in Ukrainian)

22. On Amendments and Declaring Lapsed Some Legislative Acts of Ukraine. The Law of Ukraine dated December 28, 2014 No. 76-VIII. [Electronic resource]. - Access mode: http://zakon2.rada.gov.ua/ laws/show/76-19/paran130\#n130. (in Ukrainian)

23. On Amendments to Some Legislative Acts of Ukraine on Extending the Authorities of Local Self-Government Bodies and Optimizing the Provision of Administrative Services. The Law of Ukraine dated December 10, 2015 No. 888-VIII. [Electronic resource]. - Access mode: http://zakon2.rada.gov.ua/laws/show/888-19/paran44\#n44. (in Ukrainian)

24. On Amendments to Some Legislative Acts of Ukraine on the Implementation of the Automated System of Accounting for Fare Payment in Urban Passenger Transport. The Law of Ukraine dated January 17, 2017 
No. 1812-VIII. [Electronic resource]. - Access mode: http://zakon2.rada.gov.ua/laws/show/1812-19/paran39\#n39. (in Ukrainian)

25. On election of deputies of the Verkhovna Rada of the Autonomous Republic of Crimea, local councils and village, settlement, city mayors. The Law of Ukraine dated July 10, 2010 No 2487-VI. [Electronic resource]. - Access mode: http://zakon3.rada.gov.ua/laws/show/2487-17. (in Ukrainian)

26. Martseliak O.V. Electoral system in Ukraine: search for the optimal model // Bulletin of the Kharkiv National University of Internal Affairs. 2007. - No. 37. - P. 73-84. (in Ukrainian)

27. Tolkovanov V.V. Priorities and approaches to modernization of local self-government at the present stage: domestic and foreign experience // The theory and practice of public administration and local self-government. - 2017. - No. 1. [Electronic resource]. - Access mode: http://el-zbirn-du.at.ua/2017_1/28.pdf. (in Ukrainian)

28. Belukha L.A. The concept of territorial community and capable territorial community / Theory and practice of public administration. 2017. - No. 1(56). [Electronic resource]. - Access mode: http://www.kbuapa.kharkov.ua/e-book/tpdu/2017-1/doc/3/02.pdf. (in Ukrainian)

29. Stop the practice of finding reasons and take legal opportunities Minregion to the CEC: Decentralization. - 2017. - [Electronic resource]. Access mode: http://decentralization.gov.ua/news/7380. (in Ukrainian)

30. First Elections in United Communities. An Analytical Report. Committee of Voters of Ukraine. Kyiv. - 2017. - 45 p. (in Ukrainian)

31.Decentralization - 2017. The reform will go on. - 2017. [Electronic resource]. - Access mode: https://sorada.gov.ua/actual/18489detsentralizatsija-2017-reforma-bude-prodovzhuvatys.html. (in Ukrainian)

32. On Amendments to Some Legislative Acts of Ukraine (on Voluntary Association of Territorial Communities). The Law of Ukraine dated June 03, 2016. No. 4772. [Electronic resource]. - Access mode: http://w1.c1.rada.gov.ua/pls/zweb2/webproc4_1?pf3511=59314.

Ukrainian)

33. On Amendments to Some Legislative Acts of Ukraine on the Features of Voluntary Association of Territorial Communities Located in the Territories of Adjacent Areas. The Law of Ukraine dated December 09, 2016 No. 5520. [Electronic resource]. - Access mode: http://w1.c1.rada.gov.ua/pls/zweb2/webproc4_1?pf3511=60681.

(in Ukrainian) 
34. On Amendments to the Law of Ukraine "On Voluntary Association of Territorial Communities" on the voluntary accession of territorial communities of villages, settlements to territorial communities of cities of regional significance. The Law of Ukraine dated April 03, 2018 No. 2379-VIII. [Electronic resource]. - Access mode: http://w1.c1.rada.gov.ua/pls/ zweb2/webproc4_1?pf3511=61814. (in Ukrainian)

35. Opinion of the Head Scientific and Expert Office on the Draft Law «On Amendments to the Law of Ukraine "On Voluntary Association of Territorial Communities" on the voluntary accession of territorial communities of villages, settlements to territorial communities of cities of regional significance» dated June 06, 2017. [Electronic resource]. - Access mode: http://w1.c1.rada.gov.ua/pls/zweb2/webproc4_1?pf3511=61814. (in Ukrainian)

\section{Information about the author:}

Panchyshyn R. I.,

Candidate of Juridical Science, Postdoctoral Student at the Department of Constitutional Law and Comparative Law, Uzhgorod National University 3, Narodna Sq., Uzhhorod, 88000, Ukraine 


\section{CONCEPT AND BASIC FEATURES OF THE ADMINISTRATIVE ACTIVITIY OF THE REVENUE AND DUTYAUTHORITIES EXECUTING CUSTOMS AFFAIRS}

\section{Pryimachenko D. V.}

\section{INTRODUCTION}

Development of Ukraine as a social, legal state is directly related to increasing of public administration effectiveness, which is aimed at ensuring the sustainable development of society, timely identification, prevention and neutralization of real and potential threats to national interests in all areas of public life without exception.Ensuring an adequate level of national security of the state that meets the requirements of the present is one of the most important functions of the state. Public administration bodies are involved in the implementation of this function.Important role in ensuring national security belongs to the revenue and duties authorities, whose tasks and functions are aimed at protecting the national interests and rights of citizens and economic entities in the field of customs law regulation.

An analysis of the legal nature and content of the activity of the revenue and dutiesauthorities executing customs affairs should be carried out with taking into account the fact that this state organization was created in March 2013 as a result of reorganization of the State Customs Service of Ukraine and the resumption of its activity in $2018^{1}$. Currently, these authoritiesarean integral part of the structure of the State Customs Service of Ukraine (hereinafter referred to as the SFS of Ukraine) ${ }^{2}$.

1 Pro Ministerstvo dokhodiv i zboriv: Ukaz Prezydenta Ukrainy vid 18.03.2013 r. № 141/2013 Ofitsiinyi visnyk Ukrainy. 2013. № 22. St. 739. (In Ukrainian); Pro utvorennia Derzhavnoi fiskalnoi sluzhby Ukrainy: Postanova Kabinetu Ministriv Ukrainy vid 21 travnia 2014 r. № 160. Ofitsiinyi visnyk Ukrainy. 2014. № 46. St. 1213. (In Ukrainian).

2 Pro utvorennia Derzhavnoi fiskalnoi sluzhby Ukrainy: Postanova Kabinetu Ministriv Ukrainyvid 21 travnia 2014 r. № 160 Ofitsiinyi visnyk Ukrainy. 2014. № 46. St. 1213. (In Ukrainian); Pro utvorennia derzhavnoi podatkovoi sluzhby Ukrainy ta Derzhavnoimytnoi sluzhby Ukrainy: Postanova Kabinetu Ministriv Ukrainy vid 18 hrudnia 2018 r. № 1200. Ofitsiinyi visnyk Ukrainy. 2019. № 7. St. 208. (In Ukrainian). According to the current customs legislation (clauses 34-1, part 1, article 4 of the Customs Code of Ukraine), the bodies of revenue and duties are: the State Customs Service of Ukraine is the central executive body that provides for the formation and implementation of state tax and customs policy and its territorial divisions: customs and customs posts. Before the reorganization of the SFS of Ukraine in 2013, these authorities were called customs authorities.) 
In the process of carrying out their tasks and functions, the revenue and duties authorities actively use various in nature, forms and methods means and approaches of influence on public relations in order to regulate it. Among this set of means, we can single out, as they are defined in the legal literature, administrative legal means.The practical implementation of administrative remedies is carried out within the framework of activity, which has been called administrative in the legal literature ${ }^{3}$.

Of course, the fulfillment by the revenue and duties authorities of their functions involves the implementation, in addition to administrative, also other types of activity, for example, criminal procedural or financial and economic.However, in terms of volume and variety of carried out tasks, administrative activity occupies one of the most important places in the functioning of the revenue and duties authorities.Administrative activity is a type of state-governmental activity of executive bodies and covers a wide range of public relations, which are formed both within the system of the revenue and duties authorities, and beyond.

\section{Administrative activity: problems of definition and regulatory fixing}

Researching of the administrative activity concept and determining its features causes some difficulties, since the term «administrative activity» is not used in the current legislation, and in modern scientific literature is used in several different meanings, but is mostly identified with the term «public administration». ${ }^{4}$ In addition, the complexity of the study of this legal phenomenon is caused by the dynamic formation and development of the object and subject of the administrative activity, increasing the number of public administration bodies that carry it out. The definition "administrative activity" itself is not new to the science of administrative law. In scientific circulation this term was introduced by the Soviet administrative law researcher I.I. Yevtykhiyev, who defined administrative activity as the activity of executive and administrative bodies in the form of issuing acts of management and enforcement ${ }^{5}$.

In order to clarify the essence of the concept of administrative activity, it is necessary to analyze the most common definitions in the

\footnotetext{
${ }^{3}$ Pryimachenko D.V. Administratyvna diialnist mytnykhorhaniv: problemy teorii ta praktyky: Monohrafiia. Dnipropetrovsk: AMSU, 2007. 290 s. S. 9. (In Ukrainian).

${ }^{4}$ Petrov H.Y. Pooshchrenye v hosudarstvennom upravlenyy. Yaroslavl: Yzd-vo Yaroslavskoho un-ta, 1983. 219 s. S. 89. (In Russian).

${ }^{5}$ Pryimachenko D.V. Administratyvna diialnist mytnykhorhaniv: problemy teorii ta praktyky: Monohrafiia. Dnipropetrovsk: AMSU, 2007. 290 s. S. 174. (InUkrainian).
} 
administrative and legal literature. Thus, L.V. Koval means issuing of normative and individual acts under administrative activity ${ }^{6}$. However, the proposed definition, first, does not allow to determine the sphere of public activity in which it can be implemented and the entities authorized to carry out such activity, and secondly, it is related only to the issuance of legal acts that leaves outside such forms of activity as, for example, legal actions or organizational arrangements.

Some authors associate the existence of administrative activity with its normative fixing with the help of norms of administrative law ${ }^{7}$ or with the use of administrative and legal means by which it is carried out ${ }^{8}$. Existence of such a position can be explained by the influence of the continental system of administrative law, mainly France. For example, one of the most respected administrative law researchers, G. Vedel, argues that administrative activity (in other words, management) is a set of actions of the state and other public legal entities (departments, local collectives, communes) and public administrations that are not dependent on other than administrative regime owing to its special condition.However, talking about administrative regime, he is referring to the common law regime that regulates the activity of the state and public legal entities ${ }^{9}$. In other words, administrative activity is the activity of the state (state bodies) and other public legal entities regulated by the rules of general (administrative) law. This position is, in fact, correct, but it does not disclose the nature and content of this activity.

Some researchers define administrative activity as the activity of public authorities aimed at ensuring the protection of rights, public order and public safety, detection, termination and prevention of offenses ${ }^{10}$.

In this case, administrative activity is reduced to its understanding as a law enforcement activity carried out by various executive bodies. In the Soviet era scientists' studies, who investigated theoretical problems of public administration, there are positions on the identity of the concepts of public administration as an organizational executive and administrative

${ }^{6}$ Koval L.V. Administratyvne pravo Ukrainy: Kurslektsii. K.: Osnovy, 1998. 208 s. S. 116. (In Ukrainian).

${ }^{7}$ Administratyvna diialnist OVS. Zahalnachastyna: Pidruchnyk / Za zah. red. I.P. Holosnichenka, Ya.Iu. Kondratieva. K.: UAVS, 1995. 177 s. S. 6. (In Ukrainian).

${ }^{8}$ Administratyvna diialnist: Navchalnyi posibnyk / Zazah. red. dotsenta O.I. Ostapenka. Lviv: LIVS, 2002. 252 s. S. 5.(In Ukrainian).

${ }^{9}$ VedelZh. Admynystratyvnoe pravo Frantsyy. M.: Prohress, 1973. 512 s. S. 50-54. (In Russian).

${ }^{10}$ Zarosylo V.O. Porivnialnyi analiz administratyvnoi diialnosti militsii Ukrainy ta politsii zarubizhnykhkrain (Velykobrytanii, SShA, KanadytaFrantsii): Dys... k. yu. n. / 12.00.07. K.: Natsion. akademiiavnutr. sprav, 2002. 250 s. S. 13.(In Ukrainian). 
activity of state bodies and administrative activity ${ }^{11}$. Such views occur in Western European administrative and legal science. Thus, in German administrative law, administrative activity is defined as planned human activity aimed at achieving certain social goals ${ }^{12}$. And well-known specialist in management problems I. Chepel defines administrative activity as the process of achieving national goals through the activity of public administrations ${ }^{13}$.

Among Russian scholars, there is now a position according to which administrative activity is public administration in a narrow sense, that is, the activity of executive bodies, executive-administrative bodies of the state in the exercise of executive power at its various levels ${ }^{14}$. Such an understanding of administrative activity takes into account only its managerial nature, and therefore not fully, and what is more, does not accurately reflect the purpose of this type of activity. It is indisputable that in the course of administrative activity, in addition to the powers of administrative content, other powers of the executive authoritiesarealso exercised, such as such as administrative services, taxes or other mandatory fees, enforcement measures, including administrative penalties for offenders, etc.

The analysis of various literary sources shows that commonly the concept of administrative activity is used to characterize the specific type of activity of law enforcement agencies (police, police), which, in our opinion, does not significantly affect the nature of the activity, called administrative.

In the scientific literature devoted to the study of issues of organization and activity of law enforcement agencies, administrative activity is understood as the activity of the police, in the process of practical implementation of which (ie the police - note is mine) its apparatus, services, employees are guided by administrative law ${ }^{15}$. One of the first who formulated the definition of administrative action, linking it with certain police functions, was L.L. Popov. In his opinion, the administrative activity of the police is an activity related to the protection of order in public places, ensuring the safety of traffic and pedestrians, rules of using transport, with

${ }^{11}$ Lunev A.E. Teoretycheskye problemы hosudarstvennoho upravlenyia. M.: Nauka, 1974. 248 s. S. 8, 164. (In Russian).

12 Admynystratyvnoe pravo zarubezhnыkh stran: Uchebnyk / Podred. A.N. Kozыryna y M.A. Shtatynoi. M.: Spark, 2003. 464 s. S. 31. (In Russian).

${ }^{13}$ Administrative management for development / Ed. by Y. Chapel. Brussel, 1947. 40 s. S. 40. (In Russian).

${ }^{14}$ Tykhomyrov Yu.A. Teoryiakompetentsyy. M.: Yurynformtsentr, 2001. 355 s. S. 157. (In Russian).

${ }^{15}$ Eropkyn M.Y., Popov L.L. Admynystratyvno-pravovaia okhrana obshchestvennoho poriadka. L.: Lenyzdat, 1973. 328 s. S. 101.(In Russian). 
observance of the passport system ${ }^{16}$. The authors of the textbook "Administrative activity of law enforcement agencies" define the administrative activity of law enforcement agencies as regulated by the rules of administrative law, their executive power aimed at ensuring the personal security of citizens, protecting their rights and freedoms, legitimate interests, public order, public security and combating offenses ${ }^{17}$. I.P. Golosnichenko continues to defend this position. ${ }^{18} \mathrm{~A}$ number of scientists define the administrative activity of law-enforcement bodies as specific, executiveadministrative, sub legislative, state-governmental activity consisting in the organization and implementation of public order protection, public safety, prevention and termination of crimes and other offenses ${ }^{19}$. Or as a purposeful, organizing, executive and administrative activity, which consists in the immediate, daily, practical implementation of tasks and functions in the sphere of internal affairs ${ }^{20}$.

These concepts of administrative activity somewhat limit the content of this activity and reduce it to providing the internal affairs bodies with the functions of protecting legal relations, in fact identifying it with law enforcement activity.

At the same time, the authors of these concepts, although they say that the police carries out law-enforcement administrative activity, but point to its servicing nature, recognizing it as a means of ensuring law enforcement activity $^{21}$.

Some element of novelty is given the definition of the analyzed concept contained in the glossary of terms and concepts of administrative activity, namely: the administrative activity of the police is an executive and administrative activity on the organization of work of subordinate services, employees and practical implementation of public order and protection

${ }^{16}$ Popov L. Ubezhdenye y prynuzhdenye. Orhanyzatsyonno-vospytatelnye y admynystratyvno-pravovye sredstva okhranы obshchestvennoh oporiadka $v$ deiatelnosty sovetskoi mylytsyy. M.: Moskovskyi rabochyi, 1968. 160 s. S. 5. (In Russian).

${ }^{17}$ Administratyvna diialnist OVS. Zahalna chastyna: Pidruchnyk / Zazah. red. I.P. Holosnichenka, Ya.Iu. Kondratieva. K.: UAVS, 1995. 177 s. S. 7.(In Ukrainian).

${ }^{18}$ Administratyvne pravo Ukrainy. Akademichnyi kurs: Pidruch.: U 2 t. / Red. kolehiia: V.B. Averianov (holova). K.: Yurydychnadumka, 2005. T. 2. Osoblyva chastyna. 624 s. S. 349. (In Ukrainian).

${ }_{19}$ Administratyvna diialnist: Navchalnyi posibnyk / Zazah. red. dotsenta O.I. Ostapenka. Lviv: LIVS, 2002. 252 s. S.8. (In Ukrainian).

${ }^{20}$ Admynystratyvnaia deiatelnost orhanov vnutrennykh del: Uchebnyk / Podred. dokt. yuryd. nauk, prof. A.P. Koreneva. M.: Moskovskyi un-t MVD Rossyy, yzd-vo «Shchyt-M», 2003. Chastobshchaia. 309 s. S. 38. (In Russian).

${ }^{21}$ Administratyvna diialnist OVS. Zahalnachastyna: Pidruchnyk / Zazah. red. I.P. Holosnichenka, Ya.Iu. Kondratieva. K.: UAVS, 1995. 177 s. S. 8. (InUkrainian). 
public safety by administrative and legal means ${ }^{22}$. This concept draws attention not only to the external but also to the internal orientation of the activity carried out by law enforcement agencies.

The most general definition of this concept can be considered as follows: administrative activity of law-enforcement bodies - a purposeful, organizing, executive and administrative activity, which consists in the direct, daily, practical implementation of tasks and functions of the state in the sphere of internal affairs ${ }^{23}$. This definition of administrative activity that, in our view, most fully and adequately reflects the content of this type of activity of law enforcement agencies. At the same time, it should be noted that in all the above positions, the content of the concept is invested by the activity of a special entity aimed at achieving the desired goal.

The analysis of legal acts regulating the activity of the bodies of revenue and duties, carrying out customs affairs, their officials and practice of application, shows that the administrative nature is the activity of many divisions of bodies of revenue and duties, which, in particular, covers the provision of the order of movement through the customs border of goods, objects and vehicles, the implementation of customs control and customs clearance of objects of movement, control over the movement across the customs border of goods containing objects of law and intellectual property, taking measures of tariff and non-tariff regulation when moving goods across the customs border, prevention and termination of customs offenses, etc.

In addition, the administrative and legal means used by officials of the revenue and duties authoritiesarewidely used in the process of creating favorable conditions for accelerating trade and passenger traffic across the customs border, verification of certificates of origin of goods.

Thus, on the one hand, the administrative activity of the revenue and duties authorities cover law-making and individual-administrative activity aimed at positive regulation of public relations in the customs and legal sphere in accordance with the rules of laws and other normative acts. Components of administrative activity for this purpose are:

- sub-legislative normative regulation of public relations is carried out by issuing (adopting) revenue and duties authorities of sub-normative acts aimed at establishing general rules for an indefinite number of

\footnotetext{
${ }^{22}$ Borodyn S.S., Yvanov P.V., Oskyn F.F. Admynystratyvnaia deiatelnost orhanov vnutrennykh del: Slovartermynov y poniatyi. SPb.: Lan, 2000. 240 s. S. 6. (In Russian).

${ }^{23}$ Admynystratyvnaia deiatelnost orhanov vnutrennykh del: Uchebnyk / Podred. dokt. yuryd. nauk, prof. A.P. Koreneva. M.: Moskovskyi un-t MVD Rossyy, yzd-vo «Shchyt-M», 2003. Chastobshchaia. 309 s. S. 38. (In Russian).
} 
people in accordance with the laws and legal acts of other public administration bodies;

- individual regulation of public relations in accordance with the laws and legal acts of other public administration bodies, which is carried out by issuing (adopting) revenue and duties authorities regulatory legal acts and performing administrative actions in relation to individually defined entities (citizens, business entities), aimed at establishing, changing and termination of their rights and obligations.

On the other hand, the administrative activity of the revenue and duties authorities is aimed at preventing the commission of violations of customs rules, their detection and termination, to ensure the customs security of the state and protection of society. For this purpose, the revenue and duties authorities, in carrying out this activity, do not manage the subjects of moving, do not regulate their behavior, but provide security and protection of the rights and legitimate interests of citizens and the state in general from unlawful encroachments, from violations by individual subjects of moving.At its core, this activity has a protective nature

Thus, the administrative activity of the revenue and duties authorities in this sense is in fact one of the main directions of protecting the economic interests of Ukraine, creating favorable conditions for the development of its economy, protecting the rights and interests of citizens and business entities, preventing and suppressing illegal actions, and applying to offenders measures of administrative procedural support and administrative penalties.

The duality of its nature consists in existence of these two sides of the administrative activity of the revenue and duties authorities: carrying out public administration in the customs legal sphere, the of revenue and duties authorities at the same time and first of all must ensure compliance with the rule of law and order in it.Awareness of such heterogeneity of administrative activity allows to speak about existence of several of its directions.

In the light of the above, the problem of the functional purpose of the revenue and dutiesauthority'sadministrative activity is relevant. The revenue and dutiesauthority's activity should provide not rather a power-organizing influence on public relations in the customs sphere, but as promote the fullest possible enjoyment of rights and legal interests by citizens and economic operators in this spheres far as their effective protection in case of any violations, both within the state and abroad.Therefore, we should agree with the opinion of V.B. Averyanov, who believed that the activity of state institutions should be a subject to needs of enjoyment of human rights and freedoms, ensuring their priority over all other values of a democratic, 
welfare,rule-of-law state ${ }^{24}$. From his point of view, such a restructuring of the state institutions activity requires the replacement of the ideology of "domination" of the state over a man to the opposite one - the ideology of "serving" of the state to the interests of man.

\section{Basic features of the administrative activity}

The wording of the concept of administrative activity of the revenue and duties authorities requires clarification of the question regarding the signs of this specific type of activity, in other words, those features that individualize this phenomenon.

This approach also allows us to characterize the goal-setting of administrative activity in its scope - from the preparation and adoption of legal norms to itsimplementation using security mechanisms. In our opinion, the administrative activity carried out by the revenue and duties authorities is characterized by the following characteristics.

Administrative activity is a special type of activity related to the exercise of the state executive power in the field of customs legal regulation of public relations, which differs from the activity in the implementation of the legislative and judicial power by its content, form and methods.This is what is crucial for understanding the essence of this type of activity and conditions the existence of all other signs.

State-power nature of administrative activity is a type of activity which is prerogatives of the relevant competent authorities of the state - the revenue and duties authorities. Its implementation is ensured by the totality of state funds of economic and political, social and ideological, encouraging and coercive nature.State-power point is its essential feature, allowing to perform an effective means in management of public relations.The revenue and duties authorities shall exercise their powers in an official manner on behalf of the state within the competence clearly defined by law.They are empowered to monitor compliance with the established rules in the customs sphere, to give legal evaluation of doings and actions of citizens and economic operators, to identify violations and to respond on them in accordance with the procedure established by law, and also to make binding orders within their competence and to impose the same mandatory requirements, to apply compulsory measures in cases and forms provided for by law.

${ }^{24}$ Averianov V. Administratyvna reforma i pravova nauka. Pravo Ukrainy. 2002. № 3. S. 20-30. S. 25. (In Ukrainian). 
The publicity of administrative activity consists in the fact that it is carried out not to satisfy the private, personal needs of those whom it relies on, but in the interests of "one and all."

Protecting the economic interests of Ukraine, taking measures to protect the interests of consumers of goods, counteracting customs offenses, the revenue and duties authorities carry out administrative activity for the benefit of all. Thus, the right of the citizen corresponds to the duty of the revenue and duties authorities to create favorable conditions for the exercise of his right to move goods, objects, vehicles through the customs border of the state.

Administrative activity of the revenue and duties authorities is sub legislative. It is carried out on the basis and for the implementation of laws and other legal acts in the exact conformity and within the limits specified by the law, using appropriate legal means. The cited feature of administrative activity is very important and relevant, because the scope of the latter is quite broad. The activity of the revenue and duties authorities is carried out in constant interaction with citizens, subjects of foreign economic relations, other state bodies of Ukraine and foreign states, as well as with international organizations, and any deviation from the requirements of the law can cause significant damage to their rights and interests, complicate their own activity. In the process of this activity, unlawful actions of officials of the revenue and duties authorities,as well as opposition of legality and expediency are unacceptable.

The legality of administrative activity is also important because, in the course of thisactivity, the law is primarily implemented. The application of the rules of law by officials is conditioned by the solution of specific life situations and certain circumstances.

Legal subordination of administrative activity is also important because, in the course of this activity, the legal prescriptions are primarily implemented. Application of law by officials is conditioned by the solution of specific life situations and certain circumstances. For example, officials of revenue and duties authorities can make direct orders (for example, to establish additional requirements for the arrangement of temporary storage warehouses) or to take actions the content of which is to comply with the direct prescriptions of law (for example, verification of documents and information required for customs formalities).

In the process of implementing administrative activity, the competent revenue and duties authoritiesdevelop and issue sectorial regulatory acts. The rules contained therein are subordinate in nature, since these acts are adopted to comply with the requirements of the law, their specification and detail. 
In addition, the revenue and duties authoritiesareempowered to carry out activityrelated to the prosecution of violators of customs legislation and to apply compulsory measures to them independently. Undoubtedly, thisactivityshould be implemented in full compliance with the requirements of the law.

Administrative activityhas an executive and administrative character. Its main purpose is to fulfill the requirements of the current national legislation and obligations stipulated by the international treaties of Ukraine on matters within the competence of the revenue and duties authorities, that is, the practical implementation of laws and other normative acts. At the same time, for the successful and effective performance of their executive functions, they are vested with administrative powers, which provide for the ability to subordinate the objects of management of its subject.As a consequence, the relations that arise in the process of this activity are relations of subordination, powerorganizing, managing.Without the necessary administrative powers, it is almost impossible to achieve the goal of fulfilling the law and other normative acts, the day-to-day management of subordinate to the revenue and duties authorities' activity and the solution of other tasks facing SFS of Ukraine.The revenue and duties authorities issue regulations containing regulations or individual regulations, and apply coercive measures.

The administrative activity of the revenue and duties authorities covers both law-making and law-enforcement activity. The law-making activity of the revenue and duties authorities is reflected in issuing sectorial regulations governing the various relations that arise in the implementation of customs policy within the scope of its competence.

Law enforcement activity of the revenue and duties authorities consists in organizing and practically implementing the requirements of customs regulations regarding specific life cases or individually defined persons, protection and defense these standards from any violations, applying coercive measures, ensuring the execution of punishment, as well as taking preventive measures.Although, after the formation of the SCS of Ukraine and its functional subordination to the Ministry of Finance of Ukraine, law-making activity was substantially restricted, the revenue and duties authoritiesare still empowered with normative-making powers.

The activity of the revenue and fees authoritiesis a kind of organizational activity of the bodies of executive power. The organizational essence of administrative activity is manifested in the fact that in the process of its implementation joint purposeful activity of interested parties regarding solving problems in the field of customs and legal regulation of public 
relationsis organized, regulated, coordinated, in particular: issues related to the protection of national economic interests are resolving, the activityof subjects of foreign economic activity are streamlining, their right to move goods, items and vehicles across the customs border is ensured, the functioning of the SCS is maintained, international customs cooperation is carrying out.On this basis, a general state of ordering of subjects and objects of management, relations between them is created.Notably, that in the process of this activity the achievement of certain tasks is achieved on the scale of the whole society, and not only within the framework of a separate collective, a separate community of people.We must agree with the opinion of I. Sabo, who notes that in this context such activity of the state can be called transforming activity: it turns economic and other social relations into general legal relations, which are subsequently fixed in the rules in order to influence social relations turning them into legal ones. ${ }^{25}$ At the same time, administrative activity is not limited to a meaningless form, which provides stability, strength, guarantee of social, economic, political content.

In the field of customs and legal regulation, special actions which have been deliberately designed both in form and contentare being taken: shipping documents are checked, permits are issued, legal acts issued, etc.All these actions affect the behavior of participants in customs and legal relations, contributing to the most expedient and usefulfrom the point of view of society and the state, achievement of socially useful goals. This is the reason for the socially significant role of administrative activity - promoting the achievement of the public good by reconciling individual, group, public and state interests. In this sense, activity of the revenue and duties authorities should cause certain practical changes in social life, which allows recognizing it as a practical activity that has a positive socio-legal value.

Continuity, constancy and regularity of administrative activity. This feature is based on historical experience and objective laws governing the functioning of the system of the revenue and duties authorities, the main purpose of which is the direct implementation of the customs policy as part of a single national policy.In the process of the researched activity, problems are solved and the functions of the state are realized, protection of both the interests of the state and the constitutional rights and interests of citizens, as well as business entities is ensured.

Processualization of administrative activity that is a normatively regulated system of the revenue and duties authorities' actions and operations, which are consistently carried out by the bodies and their

${ }^{25}$ Sabo Y. Osnov yteoryy prava. M.: Yurydycheskaia lyteratura, 1974. 387 s. S. 74. (In Russian). 
officials, in the established procedural forms. Procedural regulation of administrative activity is the most important guarantee of ensuring the rule of law in the broadest sense of the term and an effective way of ensuring the rights and legitimate interests of citizens and economic entities. However, it should not be forgotten that administrative activity is not exclusively of a legal nature, because it consists of legal and non-legal (organizational, factual) parts.In other words, not all revenue and duties authorities' actions entail legally significant consequences.And if the legal part of the activityof the revenue and duties authorities is sufficiently detailed and clearly regulated by the rules of law, then the rest of it is subject to regulation only in general form.Within the framework of general norms on rights and obligations and separate starting procedural rules (for example, time limits), the official of the revenue and duties authoritiesindependently and creatively chooses ways and forms of solving the tasks.

Relations that arise in the process of administrative activity can be separated into two groups: relations directly related to the formation and implementation of customs policy of the state, ether implementation of executive power, and other relations, including internal organizational processes that arise in the process of formation and functioning of the system ofthe revenue and duties authorities.The priority of the relations of the first group is obvious, because the system of the SFS of Ukraine exists not for the satisfaction of its own interests, but for functioning within its purpose.

The certifying and search nature of administrative activity consists in the fact that the revenue and duties authorities forthe fulfilling their tasks and functions must collect, accumulate, analyze, officially confirm, register (certify), draw up information that will allow legitimate and justified decision to be performed.

The administrative activity of the revenue and duties authorities is characterized by a rational combination of centralized management with direct (operational) management.Centralized management is reflected in the definition of priority areas of activity (for example, in the Strategic Initiatives for the development of the SFS until $2020^{26}$, the establishment of general rules, regulations, etc.Direct (on-going) management is characterized by the existence of direct links between the higher revenue and duties authorities and their subordinates.Both management and governance are carried out using vertical (subordinate, hierarchical) or horizontal links and relations in the SCS of Ukraine.

\footnotetext{
${ }^{26}$ Stratehichni initsiatyvy rozvytku DFS do 2020 r. URL: http://sfs.gov.ua/mediatsentr/novini/322784.html (In Ukrainian).
} 
The presence of this sign improves the quality and efficiency of the realization by the revenue and duties authorities of their powers, enhances their responsibility for the failure or improper performance of their duties.On the other hand, state and local authorities are obliged to create conditions for the proper functioning of the revenue and duties authorities and assist them in performance of tasks and functions.

The administrative activity of revenue and duties authorities is carried out with a help of various means, methods and techniques - methods of activity which are externally reflected in specific actions of various nature, which are carried out within their competence and cause certain consequences - forms of activity. In the administrative-legal literature, these methods and forms of activity of executive bodies, and consequently, of the revenue and duties authorities, were called administrative-legal ${ }^{27}$, influence on social relations is exercised with their use.

One of the peculiarities of the administrative activity of the revenue and duties authoritiesis its preventive orientation, which is provided by such organization of work of all bodies, divisions, individual officials, forces and means that would create effective conditions for the existence of civilized relations connected with the movement of goods, objects and vehicles across the customs border, strict compliance with customs legislation and prevention of its violations.Success in this work is achieved only after a deep and complete analysis of the own activityat the present stage and determination of its priorities in the future, analysis of the current regulatory framework and the practice of its application by citizens and business entities, identification of the causes and conditions conducive to the commission of customs offenses.In this context, ensuring openness and transparency of the SCS of Ukraine for the public is essential.This can be realized by bringing information about the main results of the activityof the revenue and tax authorities, the general situation in this area through the media or during speeches or messages of the leaders of the SCS of Ukraine. Administrative activityis professional in nature.

Professionalism is an important feature of the researched activity. The professional nature of administrative activity is due to the fact that specialized activity requires from those who carry out it, relevant professional knowledge (law, economics, psychology) and certain skills. Taking into account that the administrative activityis coercive, it requires from those who carry it out, a good knowledge of the business, reasonable,

${ }^{27}$ Admynystratyvnoe pravo / Pod red. prof. Yu.M. Kozlova y prof. L.L. Popova. M.: Yurystъ, 1998. 728 s. S. 255. (In Russian). 
competently use of compulsion, because the baseless use of coercive measures can be regarded as an abuse of power, will cause dissatisfaction of citizens and business entities and generate conflicts.As a result, this professional activity is carried out by specially trained public servants, they are competent, which means they can effectively protect the economic interests of the state, the rights and legitimate interests of citizens and business entities in the customs sphere.

Considered signs of the administrative activityof the revenue and duties authorities, do not characterize some of its sides or aspectsin particular, butin complex as a whole phenomenon that consists of interdependent and interrelated parts.The diverse relationships and relations that arise between these components, and the properties generated by them, which define them as a system, ensure the existence of relatively independent laws of the development and functioning of administrative activity.

Considering the heterogeneity of social relations in the field of customs and legal regulation, which are conditioned by the complex nature of modern customs legislation, it should be noted that the administrative activity of the revenue and duties authorities is regulated by the norms of several branches of law: customs, financial, tax, but administrative rules are still dominant (including its procedural component).Why administrative rather than customs? First, it is worth noting that there is still no common view among the scholars regardinga sectorial nature of customs law.

Some jurists consider customs law to be an institution of administrative law $^{28}$ or its subsector, ${ }^{29}$ others recognize customs law as an independent branch of law $^{30}$ or its special industry ${ }^{31}$, however, the vast majority classifies it as complex industries ${ }^{32}$. There is an opinion that it can only be

${ }^{28}$ Belskyi K.S. Polytseiskoe pravo: Lektsyonnui kurs. M.: DYS, 2004. 815 s. (In Russian).S.463. (In Russian).

${ }^{29}$ Komziuk V.T. Administratyvno-pravovi zasady zdiisnennia mytnoi spravy: poniattia ta vydy. Visnyk Natsion. un-tu vnutrishnikhs prav. 2003. № 2. S. 189-194. S. 192. (In Ukrainian); Sandrovskyi K.K. Tamozhennoe pravo. K.: Vyshchashkola, 1974. 176 s. S. 19. (In Ukrainian).

${ }^{30}$ Tamozhennoe pravo: Uchebnyk dlia vuzov / M.M. Rassolov, N.D. Эryashvyly, V.N. Haluzo y dr.; Podred. M.M. Rassolova, N.D. Эryashvyly. M.: YuNYTY-DANA, 2005. 384 s. S. 11. (In Russian).

${ }^{31}$ Kornieva T. Mytne pravo ya ksamostiina spetsialna haluz prava. Pidpryiemnytstvo, hospodarstvo i pravo. 2005. № 9. S. 3-5. S. 5. (InUkrainian).

${ }^{32}$ Dorofieieva L.M., Yasevych M.M. MytnepravoUkrainy: navchalnyi posibnyk. Uzhhorod: PP Bereza, 2013. 268 s. S. 11. (In Ukrainian); Kormych B.A. Tamozhennoe pravo. Odesskaia shkola prava. Vvedenye v ukraynskoe pravo. / S. V. Kyvalov, N.V. Anyshchuk, T.A. Ostapenko; podobshch. red. S.V. Kyvalova. 3-e yzd. Odesa: Yurydychnaliteratura, 2016. 504 s. S. 412. (In Ukrainian); Mytnepravo Ukrainy: navchalnyi posibnyk / Za zah red. V.V. Chentsova. D.V. Pryimachenka / 2-e vyd. K.: Istyna, 2008. 328 s. S. 12. (InUkrainian). 
said about customs legislation, that is, legislation on customs ${ }^{33}$. Secondly, almost unanimously, scientists recognize that the subject of customs law regulation is a wide range of public relations, which are regulated by the norms of various branches of law, such as administrative, financial, civil, criminal, labor, etc.However, this complex of social relations, although it is heterogeneous, is nevertheless integrated with the help of such a systemforming factor as the movement of goods, objects and vehicles across the customs border into a specific set - customs relations. Third, the vast majority of these public relations, to which the revenue and dutiesauthoritiesand their officials are involved, are related to the movement of goods, objects and vehicles across the customs border, the implementation of customs procedures, the establishment of customs regimes, the legal status of the revenue and duties authorities.All these relations are of a managerial, organizational nature and, as a whole, are covered by administrative legal regulation, and therefore are regulated by the norms of administrative and administrative-procedural law. The dominance of administrative and administrative procedural norms in the process of regulating public relations in the customs sphere is recognized by such wellknown specialists in the field of customs law as M.G. Schulga ${ }^{34}$. The norms of substantive administrative law regulate relations associated with the establishment of the procedure for moving goods, objects and vehicles across the customs border, customs control, customs clearance, customs statistics, liability for violation of customs rules, types of penalties, legal status of the revenue and duties authorities, etc. The administrativeprocedural nature of the rules governing the implementation of customs procedures, proceedings on cases of violation of customs rules. The rules governing the implementation of customs procedures, proceedings on cases of violation of customs rules are administrative-procedural by their nature.

Fourth,the revenue and duties authoritiesare type of executive bodies, which carry out state-power management activity, traditionally associated with administrative law on behalf of the state.Considering that the revenue and dutiesauthoritiesas executive bodies are mandatory participants in customs legal relations, it can be argued that their activityis governed by administrative law.

${ }^{33}$ BakaevaO.Iu., Matvyenko H.V. Tamozhennoe pravo Rossyy: Uchebnyk / Otv. red. N.Y. Khymycheva. M.: Yurystъ, 2004. 427 s. S. 27. (In Russian); Kozyrin A.N. Pravovoe rehulyrovanye tamozhenno-taryfnoho mekhanyzma (sravnytelno-pravovoe yssledovanye): Avtoref. dys. ... dokt. yuryd. nauk. M.: MHYMO MYD RF, 1994. 53 s. S. 19. (In Russian).

${ }^{34}$ Shulha M.H. Poniattia mytnoho prava. Problemy zakonnosti: Resp. mizhvidomch. nauk. zb. / Vidp. red. V.Ia. Tatsii. X.: Natsion. yuryd. akad. Ukrainy, 2000. Vyp. 42. S. 124-130. S. 127. (In Ukrainian). 


\section{CONCLUSIONS}

Thus, taking into account the above-mentioned signs of administrative activity and the specifics of the sphere of customs and legal regulation of public relations, we can formulate the following definition of the concept of administrative activity of the revenue and dutiesauthorities executing customs affairs: administrative activity of the revenue and dutiesauthoritiesis a regulated mainly by administrative law norms, bylaws, purposeful, state-power, executive and administrative activity related to the practical implementation of measures aimed at the direct implementation of the state customs policy, and the organization and functioning of the system of revenue and duties.

A theoretical study of the administrative activity of the public administration bodies that directly carry out customs affairs is particularly relevant in connection with the permanent reorganization of the existing system of national customs administration, improvement of the legal regulation of its organization and functioning and bringing it into line with international standards.

\section{SUMMARY}

The article deals with development of Ukraine as a social, legal state is directly related to increasing of public administration effectiveness, which is aimed at ensuring the sustainable development of society, timely identification, prevention and neutralization of real and potential threats to national interests in all areas of public life without exception. Ensuring an adequate level of national security of the state that meets the requirements of the present is one of the most important functions of the state. Public administration bodies are involved in the implementation of this function. Important role in ensuring national security belongs to the revenue and duties authorities, whose tasks and functions are aimed at protecting the national interests and rights of citizens and economic entities in the field of customs law regulation.

In the process of carrying out their tasks and functions, the revenue and duty authorities actively use various in nature, forms and methods means and approaches of influence on public relations in order to regulate it. Among this set of means, we can single out, as they are defined in the legal literature, administrative legal means. The practical implementation of administrative remedies is carried out within the framework of activity, which has been called administrative in the legal literature.

As a result of the scientific research, the notion of administrative activity of the bodies of revenue and duty was formulated, its main features were 
identified and characterized. Thus, the administrative activity of the revenue and duty bodies carrying out customs affair is mainly regulated by the rules of administrative law, legislative, purposeful, state-power, executiveadministrative activity, related to the practical implementation of measures aimed at the direct implementation of customs policy of the state and the organization and operation of the system of revenue and duty.

\section{REFERENCES}

1. Pro Ministerstvo dokhodiv i zboriv: Ukaz Prezydenta Ukrainy vid 18.03.2013 r. № 141/2013 OfitsiinyivisnykUkrainy. 2013. № 22. St. 739. (In Ukrainian).

2. Pro utvorennia Derzhavnoi fiskalnoi sluzhby Ukrainy: Postanova Kabinetu Ministriv Ukrainy vid 21 travnia 2014 r. № 160. OfitsiinyivisnykUkrainy. 2014. № 46. St. 1213. (In Ukrainian).

3. Pro utvorennia derzhavnoi podatkovoi sluzhby Ukrainy ta Derzhavnoi mytnoi sluzhbyU krainy: Postanova Kabinetu Ministriv Ukrainy vid 18 hrudnia 2018 r. № 1200. Ofitsiinyi visnyk Ukrainy. 2019. № 7. St. 208. (In Ukrainian).

4. Pryimachenko D.V. Administratyvna diialnist mytnykh orhaniv: problemy teorii ta praktyky: Monohrafiia. Dnipropetrovsk: AMSU, 2007. 290 s. (In Ukrainian).

5. Petrov H.Y. Pooshchrenye $v$ hosudarstvennom upravlenyy. Yaroslavl: Yzd-voYaroslavskoho un-ta, 1983. 219 s. (In Russian).

6. Koval L.V. Administratyvne pravo Ukrainy: Kurslektsii. K.: Osnovy, 1998. 208 s. (In Ukrainian).

7. Administratyvna diialnist OVS. Zahalna chastyna: Pidruchnyk / Za zah. red. I.P. Holosnichenka, Ya.Iu. Kondratieva. K.: UAVS, 1995. 177 s. (In Ukrainian).

8. Administratyvna diialnist: Navchalnyi posibnyk / Za zah. red. dotsenta O.I. Ostapenka. Lviv: LIVS, 2002. 252 s. (In Ukrainian).

9. VedelZh. AdmynystratyvnoepravoFrantsyy. M.: Prohress, 1973. 512 s. (In Russian).

10.Zarosylo V.O. Porivnialnyi analiz administratyvnoi diialnosti militsii Ukrainy ta politsii zarubizhnykh krain (Velykobrytanii, SShA, Kanady ta Frantsii): Dys... k. yu. n. / 12.00.07. K.: Natsion. akademiia vnutr. sprav, 2002. 250 s. (In Ukrainian).

11.Lunev A.E. Teoretycheskye problemb hosudarstvennoho upravlenyia. M.: Nauka, 1974. 248 s. (In Russian).

12. Admynystratyvnoe pravo zarubezhnыkh stran: Uchebnyk / Pod red. A.N. Kozyryna y M.A. Shtatynoi. M.: Spark, 2003. 464 s. (In Russian). 
13. Administrative management for development / Ed. by Y. Chapel. Brussel, 1947. 40 s. (In Russian).

14. Tykhomyrov Yu.A. Teoryia kompetentsyy. M.: Yurynformtsentr, 2001. 355 s. (In Russian).

15.Eropkyn M.Y., Popov L.L. Admynystratyvno-pravovaia okhrana obshchestvennoho poriadka. L.: Lenyzdat, 1973. 328 s. (In Russian).

16. Popov L. Ubezhdenye y prynuzhdenye. Orhany zatsyonnovospytatelnye y admynystratyvno-pravovye sredstva okhranы obshchestvennoho poriadka $\mathrm{v}$ deiatelnosty sovetskoi mylytsyy. M.: Moskovskyi rabochyi, 1968. 160 s. (In Russian).

17. Administratyvne pravo Ukrainy. Akademichnyi kurs: Pidruch.: U 2 t. / Red. kolehiia: V.B. Averianov (holova). K.: Yurydychna dumka, 2005. T. 2. Osoblyva chastyna. 624 s. (In Ukrainian).

18. Admynystratyvnaia deiatelnost orhanov vnutrennykh del: Uchebnyk / Podred. dokt. yuryd. nauk, prof. A.P. Koreneva. M.: Moskovskyi un-t MVD Rossyy, yzd-vo «Shchyt-M», 2003. Chastobshchaia. 309 s. (In Russian).

19. Borodyn S.S., Yvanov P.V., Oskyn F.F. Admynystratyvnaia deiatelnost orhanov vnutrennykh del: Slovar termynov y poniatyi. SPb.: Lan, 2000. 240 s. (In Russian).

20. Averianov V. Administratyvna reforma i pravova nauka. Pravo Ukrainy. 2002. № 3. S. 20-30. (In Ukrainian).

21. Sabo Y. Osnovy teoryy prava. M.: Yurydycheskaia lyteratura, 1974. 387 s. (In Russian).

22. Stratehichni initsiatyvy rozvytku DFS do 2020 r. URL: http://sfs.gov.ua/media-tsentr/novini/322784.html (InUkrainian).

23. Admynystratyvnoe pravo / Podred. prof. Yu.M. Kozlova y prof. L.L. Popova. M.: Yurystъ, 1998. 728 s. (In Russian).

24. Belskyi K.S. Polytseiskoe pravo: Lektsyonnyi kurs. M.: DYS, 2004. 815 s. (In Russian).

25. Komziuk V.T. Administratyvno-pravovi zasady zdiisnennia mytnoi spravy: poniattia ta vydy. Visnyk Natsion. un-tu vnutrishnikh sprav. 2003. № 2. S. 189-194. (InUkrainian).

26. Sandrovskyi K.K. Tamozhennoe pravo. K.: Vyshcha shkola, 1974. 176 s. (InUkrainian).

27. Tamozhennoe pravo: Uchebnyk dlia vuzov / M.M. Rassolov, N.D. Eryashvyly, V.N. Haluzo y dr.; Podred. M.M. Rassolova, N.D. Eryashvyly. M.: YuNYTY-DANA, 2005. 384 s. (In Russian).

28. Kornieva T. Mytne pravo yak samostiina spetsialna haluz prava. Pidpryiemnytstvo, hospodarstvo i pravo. 2005. № 9. S. 3-5. (In Ukrainian). 
29. Dorofieieva L.M., Yasevych M.M. Mytne pravo Ukrainy: navchalnyi posibnyk. Uzhhorod: PP Bereza, 2013. 268 s. (In Ukrainian).

30.Kormych B.A. Tamozhennoe pravo. Odesskaia shkola prava. Vvedenye v ukraynskoe pravo. / S. V. Kyvalov, N.V. Anyshchuk, T.A. Ostapenko; podobshch. red. S.V. Kyvalova. 3-e yzd. Odesa: Yurydychna literatura, 2016. 504 s. (InUkrainian).

31. Mytne pravo Ukrainy: navchalnyi posibnyk / Za zah red. V.V. Chentsova, D.V. Pryimachenka / 2-e vyd. K.: Istyna, 2008. 328 s. (In Ukrainian).

32. Bakaeva O.Iu., Matvyenko H.V. Tamozhennoe pravo Rossyy: Uchebnyk / Otv. red. N.Y. Khymycheva. M.: Yurystъ, 2004. 427 s. (In Russian).

33.Kozy rin A.N. Pravovoe rehulyrovanye tamozhenno-taryfnoho mekhanyzma (sravnytelno-pravovoe yssledovanye): Avtoref. dys. ... dokt. yuryd. nauk. M.: MHYMO MYD RF, 1994. 53 s. (In Russian).

34. Shulha M.H. Poniattia mytnoho prava. Problemy zakonnosti: Resp. mizhvidomch. nauk. zb. / Vidp. red. V.Ia. Tatsii. X.: Natsion. yuryd. akad. Ukrainy, 2000. Vyp. 42. S. 124-130. (In Ukrainian).

\section{Informationaboutthe author:} Pryimachenko D. V., Doctor of Law, Vice-Rector on Scientific Work of the University of Customs and Finance 2/4, Vernadsky str., Dnipro, 49000, Ukraine 


\section{HUMAN RIGHTS BALANCES \\ IN HEALTHCARE FIELD UNDER THE JURISPRUDENCE OF THE EUROPEAN COURT OF HUMAN RIGHTS}

\section{Senyuta I. Ya.}

\section{INTRODUCTION}

The intertwining of medicine, law, and ethics in medical law creates a synergistic value of parallels that run counter to laws. If to speak about humanity as any human rights activity, it can be shown via the European Court of Human Rights (hereinafter referred to as ECtHR) jurisprudence. This institution is the custodian of the rule of law and constantly seeks balances to ensure human rights. The ECtHR "holds" scales with two bowls, on which the rights and legitimate interests are weighted, and a "master's hand" is required to maintain the balance of justice.

The objective of the research is to uncover several balances using ECtHR jurisprudence, national jurisprudence, and Ukrainian statutory law, to seek the rule of law and to ensure the best interests of the human in the healthcare sector.

Some aspects of health care through the prism of the ECtHR jurisprudence have been researched, in particular by such scholars as J. Balsiene, O. Drozdova, P. J. Carozza ${ }^{1}$, M.J. Curtice, T. Exworthy, N. Hutorova, V. Horodovenko ${ }^{2}$, O. Harasymiv, J. Juskevicius, Y. Kapelanska-Pregowska ${ }^{3}$, S. Matthew ${ }^{4}$, V. Pashkov, P. Rabinovych, J.A. Sweeney, L. Udovyka. The following methods of scientific cognition have been used: formal-logical method (for the analysis of the internal construction of legal regulations); method of legal modeling (with a view to implementing the main balance sheet provisions set out in international standards, in particular, the ECtHR's jurisprudence, which, in accordance

${ }^{1}$ P.G. Carozza, Human Dignity, [in:] D. Shelton (ed.), The Oxford Handbook of International Human Rights Law, Oxford 2015, pp. 345-359.

${ }^{2}$ V. Horodovenko, V. Pashkov, L. Udovyka, Protection of Patients' Rights in the European Court of Human Rights, Wiadomości Lekarskie, 2018/06. Available at: http://wl.medlist.org/ 06-2018-13/

${ }^{3}$ Kapelańska-Pręgowska J. European court of human rights (gc), case of lambert and others v. France, judgment of 5 june 2015, application NO. 46043/14. Comparative Law Review, [S. 1], v. 21, p. 157-174, feb. 2017. ISSN 0866-9449. Available.

${ }^{4}$ S. Matthew, The European Court of Human Rights Margin of Appreciation and the Processes of National Parliaments, Human Rights Law Review 2015, vol. 15, no. 4, pp. 745-774. 
with Art. 17 of the Law of Ukraine "On Enforcement of Judgments and Application of the Jurisprudence of the European Court of Human Rights", is a source of law for Ukraine); method of jurisprudence studying (to summarize the law enforcement practice); and method of law interpreting (to find out the content of the relevant legal regulations).

\section{Balance between protecting the patient's right to life and protecting his or her right to respect for privacy}

Two balances, which reveal the most pressing issues for Ukraine, and given the numerous judgments of the ECtHR, interesting for the European community as well, have been observed under the magnifying glass of the researcher. Among these, there is a balance between protecting the patient's right to life and protecting his or her right to respect for privacy. Therefore, it is necessary to find the balance between Art. 2 and Art. 8 of the Convention for the Protection of Human Rights and Fundamental Freedoms (hereinafter referred to as the Convention) ${ }^{5}$, which are of great significance for the healthcare sector.

In the case of Lambert and others v. France (2015) ${ }^{6}$, concerning Art. 2 of the Convention, the ECtHR noted that there was no consensus among member states of the Council of Europe on the authorization to terminate life-sustaining treatment, despite the fact that most states seem to allow it (the ECtHR relied on information from 39 of the 47 member states of the Council of Europe). Thus, given the complexity of the institute for the termination of life from a medical, legal and ethical point of view and the lack of agreement on it by the member states of the Council of Europe, they need to be given some discretion on this matter ${ }^{7}$. However, it should be noted that the concept of freedom of discretion is one of the most controversial and discussed in the ECtHR's jurisprudence, and therefore the limits of such freedom shall be determined on a case-by-case basis ${ }^{8}$.

Although the formalities accompanying cessation of treatment differ for different states, there is consensus on the determining role of the will of

${ }^{5}$ Convention for the protection of human rights and fundamental freedoms as of 04.11.1950 (ratified by Ukraine on 17.07.1997). URL: https://zakon.rada.gov.ua/laws/show/995_004.

${ }^{6}$ ECtHR judgment in the case of "Lambert and Others v. France" as of 15.07.2015. URL: http://hudoc.echr.coe.int/eng?i=001-155352.

${ }^{7}$ Kapelańska-Pręgowska J. European court of human rights (gc), case of lambert and others v. France, judgment of 5 june 2015, application No. 46043/14. Comparative Law Review, [S. 1], v. 21, p. 157-174, feb. 2017. ISSN 0866-9449. Available at: <https://apcz.umk.pl/ czasopisma/index.php/CLR/article/view/CLR.2016.005/10962>. Date accessed: 07 Sep. 2019. doi:http://dx.doi.org/10.12775/CLR.2016.005.

8 S. Matthew, The European Court of Human Rights Margin of Appreciation and the Processes of National Parliaments, Human Rights Law Review 2015, vol. 15, no. 4, pp. 745-774. 
the patient in deciding on the method of expression. Given that the peculiarity of the medical profession is the presence of a sufficiently large number of reasons for possible patient dissatisfaction, even the slightest deviation from the patient's expected results can provoke a conflict situation $^{9}$. States should, therefore, be free to decide not only whether to allow or prohibit the termination of life-supportive treatment and the attendant formalities, but also to establish a balance between the protection of the patient's right to life and the right to respect for his or her private life and personal autonomy. In analyzing the particularities of such a balance, one should also take into account the "meta-concept" of human dignity, which is the source of all human and patient rights, in particular ${ }^{10}$. This concept serves to support the decisive role of the right to respect for privacy and personal autonomy ${ }^{11}$. It follows from the ECtHR's jurisprudence that, despite the "sanctity" of life, in some cases, patient autonomy may prevail in respect of respect for human dignity and freedom, which is "the very essence of the Convention"12.

It is the patient, even in a state where he or she is unable to express his or her will, whose consent should be the essence of the decision-making process in which he or she is the main subject and participant. The Council of Europe "Guidance on decision-making for patients of all ages, at the end of their lives" indicate that the patient is involved in the decisionmaking process through a wish that he or she could have orally expressed to one of the family members or one of the relatives. The ECtHR also notes that, in accordance with the comparative law information provided, in some states, in the absence of a prior order or "biological will", the patient's willful expression of will is established by various means (statements by the legal representative, family, other evidence of the patient's identity, his or her conviction etc).

In such case, the State Council, based on the evidence received, found that they were sufficiently precise to determine Vincent Lumber's desire to

${ }^{9}$ V. Horodovenko, V. Pashkov, L. Udovyka, Protection of Patients' Rights in the European Court of Human Rights, Wiadomości Lekarskie, 2018/06. Available at: http://wl.medlist.org/ 06-2018-13/

${ }^{10}$ P.G. Carozza, Human Dignity, [in:] D. Shelton (ed.), The Oxford Handbook of International Human Rights Law, Oxford 2015, pp. 345-359.

${ }^{11}$ Kapelańska-Pręgowska J. European court of human rights (gc), case of lambert and others v. France, judgment of 5 june 2015, application NO. 46043/14. Comparative Law Review, [S.l.], v. 21, p. 157-174, feb. 2017. ISSN 0866-9449. Available at: <https://apcz.umk.pl/czasopisma/ index.php/CLR/article/view/CLR.2016.005/10962>. Date accessed: 07 Sep. 2019. doi:http://dx.doi.org/10.12775/CLR.2016.005.

${ }^{12}$ ECtHR judgment in the case of "Pretty v. United Kingdom" as of 29.04.2002. URL: http://hudoc.echr.coe.int/eng?i=001-60448. 
discontinue or continue treatment. The Court found the requirements of Art. 2 of the Convention, both the legislative framework provided by the Council of Ministers and the decision-making process that was conducted in good faith in the present case. The ECtHR stated that the domestic authorities, in the light of the discretion afforded them in the present case, adhered to their positive obligations under Art. 2 of the Convention.

This issue has become especially important for Ukraine recently, as on 05.06.2019 the Order of the Ministry of Health of Ukraine "On Approval and Implementation of Medical and Technological Documents on Standardization of Emergency Medical Care” No. 1269 (hereinafter - the $\mathrm{MOH}$ of Ukraine Order 1269), by which the clinical protocol "Emergency medical care: pre-hospital stage" (hereinafter - the New clinical protocol) ${ }^{13}$ was approved, had been adopted. This act introduces into the legal system of Ukraine the principles "Do not resuscitate" and "Preliminary order" for the first time. In Section 4.4. The New clinical protocol stipulates that the patient shall carry one of the following documents or a valid alternative (for example, an identification bracelet indicating the patient's wishes). Let us consider two of the above: 1) the order "Do not resuscitate" defines a ban on cardiopulmonary resuscitation and intubation in a situation of cardiac arrest or its onset in a patient. In foreign practice, this is known by the name: "Do not resuscitate" or "no-code"; 2) Preliminary instructions: a document describing the procedures allowed for the specified medical conditions, including all or only some of the following: what to do at cardiac arrest, whether artificial nutrition is allowed, the desire to be a donor or not, dialysis, and other parameters. This prior instruction may often not apply to urgent or transient medical conditions.

Considering these regulatory transformations, a few points should be outlined:

1) in Art. 52 of the Law of Ukraine "Fundamentals of the legislation of Ukraine on health care" (hereinafter - the Fundamentals) it is guaranteed that medical practitioners are obliged to provide full medical care to the patient who is in an emergency condition, and active measures to maintain the patient's life are stopped in case if a person's condition is defined as irreversible death. Medical practitioners are prohibited from performing

${ }^{13}$ Наказ МО3 України «Про затвердження та впровадження медико-технологічних документів зі стандартизації екстреної медичної допомоги» від 05.06.2019 р. № 1269 . URL: https://moz.gov.ua/article/ministry-mandates/nakaz-moz-ukraini-vid-05062019--1269pro-zatverdzhennja-ta-vprovadzhennja-mediko-tehnologichnih-dokumentiv-zi-standartizaciiekstrenoi-medichnoi-dopomogi (Nakaz MOZ Ukrayiny "Pro zatverdzhennya ta vprovadzhennya medyko-tekhnolohichnykh dokumentiv zi standartyzatsiyi ekstrenoyi medychnoyi dopomohy" vid 05.06.2019 r. № 1269). 
euthanasia, that is, deliberately accelerating the death or killing of a terminally ill patient to end his or her suffering. The New Clinical Protocol appears to be correcting a national approach, which is generally unacceptable because, on the one hand, bylaws are for detailing laws and, on the other, human and citizen rights and freedoms, the guarantees of these rights and freedoms are determined under Sec. 1 Art. 92 of the Constitution of Ukraine, laws;

2) it is important to note that, for example, the analyzed item 4.4 of the New Clinical Protocol refers to different states, namely the USA. In Part 7 of Art. 3 of the Law of Ukraine "On emergency medical care" states that the provision of emergency medical care to a person in an emergency at the scene, during transportation and in a health care facility is carried out in accordance with medical evidence based on clinical protocols and standards of emergency medical care, which approved by the $\mathrm{MOH}$ of Ukraine. So, it operates in the space that is the territory of Ukraine, but the text of the normative act refers to another country.

3) considering this difficult regulatory act - the New clinical protocol, it should be emphasized the following: a) $\mathrm{MOH}$ of Ukraine order 1269 repealed the orders of the $\mathrm{MOH}$ of Ukraine No. 437 of 31.08.2004 and No. 34 of 15.01.2014, which standardized the provision of emergency medical care in Ukraine, and the New clinical protocol will come into force; b) the New clinical protocol stipulates that the clinical guidelines of the NASEMSO are optional and are not intended to be inclusive or to determine local practice. They are a set of clinical guidelines that can be used as such or adapted for use at the state, regional or local levels to increase the level of patient care and orientation of emergency medical care practices. However, they are obligatory for Ukraine, since they are approved by the MOH of Ukraine Order 1269 and therefore are a by-law; c) given the regulatory definition of the legal framework, "new clinical protocol for medical care", the New clinical protocol is not subject to adaptation, so it is not surprising that the US protocol was not adapted but simply translated, but it is striking that in Ukraine the normative document, which instead of Ukraine and its regions, refers to the US states will be enforceable. And, of course, we should not forget that the new clinical protocol of medical care is obligatory for application in the case of absence of a unified clinical protocol of medical care in the same disease, provided that such clinical protocol is translated into Ukrainian and approved by the $\mathrm{MOH}$ of Ukraine, as clearly stated in item 4 of the $\mathrm{MOH}$ of Ukraine Order "On Amendments to the $\mathrm{MOH}$ of Ukraine Order as of September 28, 2012 No. 751” as of December 29, 2016 No. 1422. 
As mentioned above, the $\mathrm{MOH}$ of Ukraine abolished all unified protocols by of the MOH of Ukraine Order No. 1269.

4) the institute of "preliminary disposition" is also enshrined in the Convention for the Protection of Human Rights and Dignity in the Application of Biology and Medicine: the Convention on Human Rights and Biomedicine ${ }^{14}$, namely Art. 9 regulates the peculiarities of implementation of previously expressed wishes. If at the time of the intervention, the patient is unable to express his or her wishes, the wishes for medical intervention previously expressed by him/her shall be taken into account. It should also be noted that the Convention on Human Rights and Biomedicine has been only signed by Ukraine but not ratified.

According to Part 4 of Art. 284 of the Civil Code of Ukraine (hereinafter - the CC of Ukraine), an adult capable natural person who is aware of the importance of his or her actions and can manage them, has the right to refuse treatment. In Part 4 of Art. 43 of the Fundamentals provide that a patient who has acquired full civil capacity and is aware of the importance of his or her actions and can manage them has the right to refuse treatment. In contrast to the right of refusal, a guarantee for the preservation of life in Part 5 of Art. 284 of the CC of Ukraine and Part 2 of Art. 43 of the Fundamentals states the following: in urgent cases, in the presence of a real threat to the life of an individual, medical care is provided without the consent of the individual or his or her legal guardians. The ECtHR judgment on Jehovah's Witnesses of Moscow and Others v. Russia (2010) ${ }^{15}$ states that the very essence of the Convention is respect for human dignity and freedom, and the notion of selfdetermination and personal autonomy are important principles underlying the interpretation of guarantees of their observance. The ability to pursue such a lifestyle chosen by the citizen at his or her own will implies the possibility of pursuing activities that are perceived as harmful or dangerous to the health (physical condition) of that citizen. In the case of refusal of medical care, even in cases where the refusal of a particular method of treatment can lead to death, the compulsory treatment, without the consent of a capable, adult patient, is an interference with his / her right to personal inviolability and infringement of the rights guaranteed Art. 8 of the Convention. The freedom to agree to or refuse a particular treatment

${ }^{14}$ Convention for the Protection of Human Rights and Dignity of the Human Being with regard to the Application of Biology and Medicine: Convention on Human Rights and Biomedicine as of 04.04.1997. signed by Ukraine on 22.03.2002). URL: https://zakon.rada.gov.ua/laws/ show/994_334.

${ }^{15}$ ECtHR judgment in the case of "Jehovah's Witnesses of Moscow and others v. Russia” as of 10.06.2010. URL: http://hudoc.echr.coe.int/eng?i=001-99221. 
or to choose an alternative treatment is of primary importance for the principles of self-determination and personal autonomy. However, to preserve the meaning of such freedom, the patient shall have the right to make decisions by their views and values, which would seem irrational, unreasonable and short-sighted to other people. Freedom of choice and self-determination are fundamental components of life, and in the absence of any indication of the need to protect third parties, for example, through forced vaccination of the population during an epidemic, the state should refrain from interfering with the freedom of choice of citizens in matters of health care, since intervention can only reduce, not increase, vital values.

In the case of Arskaya v. Ukraine (2014) ${ }^{16}$, the ECtHR stated that the freedom to agree or refuse assigned treatment is an extremely important principle of self-determination and personal independence. In the field of medical care, refusal of certain treatment may inevitably lead to death, but the imposition of treatment without the consent of a mentally healthy adult is a neglect of the physical integrity of the person in such a way that it may violate the rights enshrined in paragraph 1 of Art. 8 of the Convention. In the case of Glass v. The United Kingdom (2004) ${ }^{17}$, the ECtHR noted that the dispute between the applicants and the hospital staff had to be referred to the courts and that the treating physicians of the applicant were mistaken in that they were faced with an emergency. The ECtHR considers that these issues should be dealt with in the light of Paragraph 2 of Article 8 of the Convention concerning the "necessity" of interference, not in terms of the requirement to intervene "by law". The ECtHR considers that the measure taken by the hospital staff was intended, in the clinical opinion, to protect the applicant's interests. In this regard, the ECtHR recalls that in its interim decision as of March 18, 2003, on the admissibility of the application, it rejected any suggestion under Art. 2 of the Convention, stating that doctors intended to unilaterally speed up the death of the applicant either by administering diamorphine to him or by inserting a DNR into his medical card. Given of the circumstances of the case, the ECtHR considers that the decision of the authorities to disregard the applicant's objection to the proposed medical measure, in the absence of appropriate judicial authorization, led to a violation of Art. 8 of the Convention. However, the Court notes, as in its decree on the admissibility of the statement, that such an order only excluded the use of vigorous heart

\footnotetext{
${ }^{16}$ ECtHR judgment in the case of “Arskaya v. Ukraine” as of 05.03.2014. URL: http://hudoc.echr.coe.int/eng?i=001-138590.

${ }^{17}$ ECtHR judgment in the case of "Glass v. The United Kingdom" as of 09.03.2004. URL: http://hudoc.echr.coe.int/eng?i=001-61663.
} 
massage and intensive respiratory support, but did not preclude the use of other means, such as oxygenation, to support the applicant's life.

In this segment of the research national jurisprudence cannot be ignored, namely the judgment of the Lipovodolynskyi district court of Sumy region as of 14.11 .2018 , case № $581 / 625 / 18^{18}$, which decided to oblige the Lipovodolinsky central district hospital to accept the refusal of PERSON_2 from any medical interventions by the medical staff of this institution, except in urgent cases, in the presence of a real threat to the life of the individual (the plaintiff in the case), as well as the inability to obtain for objective reasons consent to such intervention. PERSON_2 filed a lawsuit stating that on August 13, 2018, he had appealed to the Lipovodolynskyi district hospital to refuse any medical interventions without his consent, but the defendant denied him the exercise of his right to refuse medical interventions. Defending his position, in particular, the plaintiff stated that it was the duty of doctors to provide all patients and persons seeking medical care with appropriate medical services while explaining the consequences of not applying one or the other treatment or diagnostic methods. In cases where the condition of the individual threatens his life or he becomes unconscious due to another painful condition, in such cases the consent of the person to medical interventions is not obtained and the necessary medical assistance is provided immediately. We support the ECtHR's position in Arskaya v. Ukraine: The ECtHR considers that the issue of the legal significance of refusing $\mathrm{S}$. to vital treatment needed to be addressed at the appropriate time, namely when medical staff refrained from offering the treatment offered under the patient's decision. Therefore, according to national law, the decision to refuse at the moment of exercising the right of refusal appears correct ${ }^{19}$.

\section{The balance of private and public interests}

Another balance that seems to be interesting for the Ukrainian legal system is the balance of private and public interests. Taking into consideration the dispersion of each of the interests a balance in the

\footnotetext{
${ }^{18}$ Рішення Липоводолинського районного суду Сумської області від 14.11.2018 р. (справа № 581/625/18). URL: http://reyestr.court.gov.ua/Review/77899139 (Rishennya Lypovodolyns'koho rayonnoho sudu Sums'koyi oblasti vid 14.11.2018 r. (sprava № 581/625/18).

19 Сенюта I.Я. Право людини на медичну допомогу та свобода. URL: https://www.academia.edu/39343553/\%D0\%9F\%D0\%A0\%D0\%90\%D0\%92\%D0\%9E_\%D0\% 9B\%D0\%AE\%D0\%94\%D0\%98\%D0\%9D\%D0\%98_\%D0\%9D\%D0\%90_\%D0\%9C\%D0\%95\% D0\%94\%D0\%98\%D0\%A7\%D0\%9D\%D0\%A3_\%D0\%94\%D0\%9E\%D0\%9F\%D0\%9E\%D0\% 9C\%D0\%9E\%D0\%93\%D0\%A3_\%D0\%A2\%D0\%90_\%D0\%A1\%D0\%92\%D0\%9E\%D0\%91\% D0\%9E\%D0\%94\%D0\%90 (Senyuta I.YA. Pravo lyudyny na medychnu dopomohu ta svoboda).
} 
researched area can be found. Under the general principles of medical ethics and deontology, which are fully consistent with the Hippocratic Oath, the patient's right to confidentiality must prevail over all other interests. However, there is an opinion in the scientific literature that in modern conditions this statement is a fiction ${ }^{20}$. The particularities of balancing the private interests of a certain person with public ones can be illustrated by ECtHR judgments listed below.

In the case of Z. v. Finland (1997) ${ }^{21}$, ECtHR outlines, in particular, that on September 23, 1992, Senior Doctor L. lodged a complaint with the Parliamentary Ombudsman against a court order requiring him to testify. In the Opinion as of February 5 1993, the Parliamentary Ombudsman expressed the view that national law had not been violated and the city court. The court, while investigating the crime, had duly balanced the public interest and the applicant's right to maintain medical secrecy. The ECtHR considers that protecting personal information, not just medical information, is extremely important for a person to exercise his or her right to respect for privacy and family life, as guaranteed by Art. 8 of the Convention. Respect for the confidentiality of one's health information is an integral principle of the legal systems of the States Parties to the Convention. Not only the respect for the patient's medical secrecy is decisive, but also his or her confidence in the medical profession and medical services in general. Therefore, domestic law shall provide guarantees sufficient to prevent the transmission or disclosure of medical secrecy, which may be contrary to the provisions of Art. 8 of the Convention (see $\S$ c, Art. 3, 5, 6 and 9 of the 1981 Convention for the Protection of Individuals with regard to Automatic Processing of Personal Data). The ECtHR points out that the considerations outlined above are particularly important when it comes to non-disclosure of information regarding a person's HIV illness since disclosure of such information can significantly affect a person's private and family life, social status, and employment, putting such a person at risk of becoming an exile in society. Therefore, an interest in the confidentiality of such information will be of greater importance in determining whether interference with the exercise of this right is consistent with the purpose of the law being prosecuted. Such interference cannot be recognized as necessary under with Art. 8 of the Convention unless it is justified by certain overriding public interests.

\footnotetext{
${ }^{20}$ J. Payne-James, I. Wall, P. Dean. Medicolegal Essentials in Healthcare. $2^{\text {nd }}$ edition Cambridge University Press, 26.11.200. 284 p.

${ }^{21}$ ECtHR judgment in the case of “Z. v. Finland” as of 28.02.1997. URL: http://hudoc.echr.coe.int/eng?i=001-58033.
} 
At the same time, the ECtHR recognizes that the interests of the investigation of the crime and the publicity of the trial may outweigh the interests of both the patient and the public as a whole in relation to the non-disclosure of medical secrecy (see Article 9 of the 1981 Convention, which states that such interests (in crime investigations) are even more important).

In the judgment of Avilkina and Others v. Russia (2013) ${ }^{22}$, the ECtHR reiterated that maintaining the confidentiality of health data is crucial not only to protect the privacy of the patient but also to maintain his or her confidence in health professionals and the health care system as a whole. In the absence of such safeguards, those in need of medical assistance may refrain from seeking the necessary treatment, thereby endangering their health. However, the interests of patients and the public as a whole in protecting the confidentiality of medical information may be outweighed by the interests of investigating and punishing crimes, as well as ensuring the transparency of judicial proceedings, if such interests are proven to be of greater importance. The ECtHR also recalls that, in dealing with personal data transfers, it acknowledged that the competent public authorities should retain some discretion regarding the establishment of a fair balance between relevant public and private interests, which conflict with each other. However, such discretion is accompanied by European supervision. Referring to the unlimited powers of the prosecutor's office to request information that constitutes medical secrecy, the courts found it legitimate to transmit such information and refused to satisfy the applicants' claim. The ECtHR does not see in the text of the court rulings any indication that the national authorities have tried to strike a fair balance between the applicants' right to respect for their private lives and the activities of the prosecutor's office aimed at protecting public health and the rights of citizens in this area. The ECtHR also supported its position in the case of Sidorova v. Russia (2019) ${ }^{23}$ mainly, the provision that the protection of personal data, including medical information, is fundamental to a person's right to respect for his or her private and family life, guaranteed Art. 8 of the Convention. However, the interests of the patient and the public at large in protecting the confidentiality of medical data may be outweighed by the interests of the investigation and the publicity of the trial if such interests are proven to be of greater

\footnotetext{
${ }^{22}$ ECtHR judgment in the case of "Avilkina and Others v. Russia” as of 07.10.2013. URL: http://hudoc.echr.coe.int/eng?i=001-120071.

${ }^{23}$ ECtHR judgment in the case of "Sidorova v. Russia" as of 28.05.2019. URL: http://hudoc.echr.coe.int/eng?i=001-193260/
} 
importance. The ECtHR also recalls that in matters relating to the disclosure of personal data, as it has already stated in other cases, competent national authorities should have some discretion to strike a fair balance between relevant conflicting public and private interests. However, such discretion implies scrutiny by the relevant European bodies, and the limits of such discretion shall depend on such factors as the nature and importance of the interests at stake and the degree of intervention. The Court notes that the applicant was neither a suspect nor a defendant in any criminal proceedings. The Government also failed to adduce any evidence regarding any administrative investigation into the complaint against the applicant. Given the material submitted, the Court did not see any urgent public need to require the applicant's confidential medical information to be disclosed.

National jurisprudence on balancing private and public interests is in line with the ECtHR's case law. In the Resolution of the Kupyanskyi City District Court of Kharkiv region as of May 31, 2017, case no. $678 / 1177 / 17^{24}$, it was found that the investigator of the Kupyanskyi police department PERSON_3 had filed a request to the Chief Doctor of Kupyanskyi Central City Hospital on the PERSON_2 being registered as psychiatric patient in connection with the need to investigate criminal proceedings №. 1201522037000270 for ref. № 85/1046 of 20.01.2016 ... Based on the above, the court considered that the evidence to confirm the guilt of PERSON_5 in the commission of the said offense, is absent, as is the absence of the composition of the offense, and therefore the administrative proceedings against PERSON_1 under Art. 188-39 Part 4 of the Code of Administrative Offenses shall be closed in the absence of the offense in his actions. In the Resolution of the Communarskyi District Court of Zaporizhzhia as of October 13, 2016, the case No. 333/4999/16- ${ }^{25}$ the judge finds it to be established that PERSON_2, being an official of the controller of personal data, in the absence of data on the conduct of pre-trial investigation trial of PERSON_4, gave unauthorized person information about the mental health of the latter, which did not comply with the procedure for protection of personal data established by the law on protection of personal data, which led to illegal access to the said data by unauthorized persons and to the violations

\footnotetext{
${ }^{24}$ Постанова Куп'янського міськрайонного суду Харківської області від 31.05 .2017 p. (справа № 628/1177/17). URL: http://reyestr.court.gov.ua/Review/66866596 (Postanova Kup’yans'koho mis'krayonnoho sudu Kharkivs'koyi oblasti vid 31.05.2017 r. (sprava № 628/1177/17).

25 Постанова Комунарського районного суду м. Запоріжжя від 13.10 .2016 p. (справа № 333/4999/16-п). URL: http://reyestr.court.gov.ua/Review/62006490 (Postanova Komunars'koho rayonnoho sudu m. Zaporizhzhia vid 13.10.2016 r. (sprava № 333/4999/16-p).
} 
of personal data rights, namely those of PERSON_4. While analyzing both judgments of national courts, it can be noted that the criteria for balancing the interests, in particular are: 1) the existence of rights of a competent person, which is caused, for example, by the investigation of criminal proceedings against an individual, the data on whom is required; 2) using such a measure to secure criminal proceedings as temporary access to personal belongings and documents, if necessary, to read them, to make copies and to obtain them (to seize them), remembering that, as a rule, in the researched field, personal belongings and documents may contain medical confidential information.

Witness immunity is important in the research of this balance. In the new wording of the Civil Procedure Code of Ukraine (hereinafter - the CPC of Ukraine) (Article 70), persons who are legally obliged to keep confidential information entrusted with confidentiality are excluded from the list subjects who cannot be questioned as witnesses about such information in connection with their professional or professional status. Previously, health professionals and other employees of the healthcare sector (for example, management and employees of health departments) were on that list. The issue of witness immunity is closely linked to a person's right to medical secrecy. Criminal Procedure Code of Ukraine (para. 2 h. 2, art. 65) provides clearer regulations with appropriate guarantees of human rights. It contains the provision, which health care professionals and other persons who became aware of illness, medical examination and its results, intimate and family aspects of a person's life, in connection with the performance of professional or official services, cannot be questioned as witnesses about the information that is a medical secret. Only a person, who has entrusted to the above persons the information which contains medical secret, can exempt them from the obligation to perform such professional duty. The amount of information that can be lawfully disclosed is also determined by the person who provided it, i.e. the patient or his or her legal representative. It should be emphasized that the procedure for such exemption is stipulated by law, and it can be provided namely as a written statement of will signed by the person who entrusted the said information. Unfortunately, nowadays the CPC of Ukraine not only did not improve the previous version of Art. 51 of the CPC of Ukraine (effective until amended), but and generally excluded from the list of persons who cannot be interrogated as witnesses, those who are obliged to keep medical secrecy, thereby endangering human rights, in particular, the rights guaranteed by Art. 8 of the Convention. 
It is necessary to draw attention to the case law, which actualizes the issue of preserving information that contains medical secret by medical professionals in the context of administration of justice. The judgment of the Kyiv Court of Appeal within the panel of judges of the Civil Trial Chamber as of 11.04.2019, case No 761 / 29995/17, made as a result of the claim of PERSON_2 to PERSON_4, State Institution "National Scientific Center 'Institute of Cardiology named after Academician M.D. Strazheska' of the NAMS of Ukraine” on the recognition of decisions and actions as illegal, compensation for moral damage. In particular, PERSON_2 indicates that on March 7, 2017, a leading researcher of the department of interventional cardiology of the State Institution "National Scientific Center 'Institute of Cardiology named after Academician M.D. Strazheska' of the NAMS of Ukraine” PERSON_4 (as the chairman of the commission that conducted his examination on March 04, 2017), while providing testimony in the courtroom of the Solomianskyi District Court of Kyiv, disclosed information that contained medical secret about PERSON_2, without his permission. PERSON_4 disclosed the above information to an unspecified number of persons, as there were media representatives in the courtroom, as well as an online broadcast of the court hearing was conducted, and it can be assumed that a lot of people in Ukraine and abroad were watching it. Such actions by a PERSON_4 violated PERSON's_2 rights to life, healthcare and medical secrecy, causing undue harm to his business reputation, honor and dignity. Thus, the doctor PERSON_4 violated Art. 32, 34 of the Constitution of Ukraine, Part 1 Article 286 of the Civil Code of Ukraine, Art. 39-1 Fundamentals of the Legislation of Ukraine on Health, Article 11 of the Law of Ukraine "On Information” when he dislosed PERSON's_2 medical secret. PERSON_2 requested the court to declare actions of PERSON_4, mainly the disclosure of doctor's and medical secrets regarding PERSON_2 on March 7, 2017, while giving evidence as a witness in the courtroom as illegal and to withdraw from leading researcher of the department of interventional cardiology of the "National Scientific Center 'Institute of Cardiology named after Academician M.D. Strazheska' of the NAMS of Ukraine” PERSON_4 in favor of PERSON_2 UAH 1000000 , as compensation for moral harm caused by the disclosure of medical secret. The panel of judges of the Court of Appeal, taking into account the provisions of the current legislation of Ukraine, promulgation by the mass media clarified opinion of the State Institution "National Scientific Center 'Institute of Cardiology named after Academician M.D. Strazheska' of the NAMS of Ukraine" concerning the state of health of the PERSON_2, provided by the authorized person with the written consent of PERSON_2 
for the disclosure of his personal data, agrees with the findings of the court of first instance that when giving evidence, as a witness, in the in the courtroom of Solomianskyi District Court of Kyiv, PERSON_4 did not violate the law regarding the prohibition of disclosure of doctor's and medical secret as regards to PERSON_2 $2^{26}$.

The above judgment clearly indicates, on the one hand, the importance of the topic, and, on the other, the problems with law implementation and enforcement. According to the results of the analysis of the legal framework with the projection on the outlined resolution, in particular, several remarks can be made: 1 ) the procedure for the release of medical professionals from the obligation to preserve medical secret is clearly defined in Part 2, Article 3. 65 of the Criminal Procedure Code of Ukraine, and therefore, in extrapolation to this case there should have been a written consent of PERSON_2 that he does not object to the disclosure of his personal data for the forensic examination, as well as to conduct the examination itself. Therefore, it seems strange to have such an expansive interpretation of the court, since the consent concerned the forensic examination and not the medical professionals; 2) the provision of information to the mass media is not a statutory requirement for the release of a healthcare professional from the obligation of keeping professional secrecy.

The ECtHR's position in Z. v. Finland ${ }^{27}$ case seems to be similar to the above statements. The Court outlines: "[t]he Finnish law provides that the applicant's medical advisers could be obliged to testify about the applicant without her consent only in very limited number of cases, namely in the case of the investigation, prosecution of committing crimes punishable by imprisonment for a term not less than six years (see paragraph 46). Since they refused to give evidence to the police, the latter had to obtain a sanction from a judicial authority, a city court, to hear them as witnesses (see paragraph 28). ... The persons involved in this process were obliged to consider this information confidential and non-disclosable... It should not be doubted that the authorized state bodies were given the right to believe that the public interest testified in favor of the investigation and prosecution of $\mathrm{X}$., who had made attempts to kill as regards to five crimes, not just three of them". Thus, the ECtHR, establishing a balance, indicates that, subject to a statutory regulation, public interest may prevail without violating human rights.

\footnotetext{
${ }^{26}$ Постанова Київського апеляційного суду від 11.04.2019 р. (справа № 761/29995/17). URL: http://reyestr.court.gov.ua/Review/81170220.

${ }^{27}$ ECtHR judgment in the case of “Z. v. Finland” as of 25.01.1997. URL: http://hudoc.echr.coe.int/ eng?i=001-145423.
} 


\section{CONCLUSIONS}

There is an urgent need to eliminate the discrepancy between the bylaws, in particular, MOH Order 1269, and the laws of Ukraine, to observe in the course of right enforcement the balance of the stated interests in order to respect human rights, as well as to ratify the Convention on Human Rights and Biomedicine, which contains many up-to-date progressive provisions and may have a positive impact on expanding and improving the content and scope of personal non-proprietary human rights in healthcare.

It is also necessary to amend Art. 70 CPC of Ukraine, in order to include medical professionals and other persons working in the field of health care to the list of subjects of witness immunity, as well as to regulate the procedure for the release of medical professionals from maintaining the professional duty of medical secrecy in the event of the death of their patient, which is not legally defined today either in criminal or in civil proceedings.

The analysis of balances in health care is aimed at achieving the key balance: the balance of interests of the health care professional and the interests of the patient, which consists in the ratio of those interests where each of the parties of legal relations in the provision of health care does not violate the subjective rights of the other party and can freely determine their actions to achieve the goal (results), which is to preserve life and health, strengthen and restore health, establish the absence of diseases in compliance with the statutory regulations of Ukraine.

\section{SUMMARY}

The article deals with the issues of human right balances in the field of healthcare. Thus, while analyzing the jurisprudence of the European Court of Human Rights, the authors highlight balancing such pairs of legal interests as patient's right to life and the right to respect of private life; private and public interests. The named issues are of significant importance in modern society.

Medical law is a branch of law that combines such important aspects of social wellbeing as law, medicine, ethics, etc. These aspects can collide and create the synergistic value of parallels. European Court of Human Rights, being the custodian of the rule of law, constantly seeks balances to ensure human rights and to develop the concept of humanity as any human rights activity. While weighting rights and legitimate interests, the balance of justice shall be maintained. 
There is an urgent need to eliminate the discrepancy between the bylaws, in particular, MoH Order No. 1269, and the laws of Ukraine; to amend Art. 70 of the CPC of Ukraine, having secured among the subjects of witness immunity medical professionals and other persons working in the field of healthcare; to observe during the law implementation and enforcement the balance of the above interests in order to respect human rights; to ratify the Convention on Human Rights and biomedicine, which contains many time-consuming progressive institutions and would have a positive impact on expanding and improving the content and scope of personal non-proprietary human rights in healthcare. The analysis of balances in healthcare is aimed at achieving the key balance: that of interests of the healthcare professional and patient, which consists in the ratio of those interests in which each of the parties in the healthcare relationships would not violate the subjective rights of the other party and exercise freely and determine their actions to achieve the goal, which is to preserve life and health, strengthen and restore health, establish the absence of diseases in compliance with the statutory regulations of Ukraine.

\section{REFERENCES}

1. P.G. Carozza, Human Dignity, [in:] D. Shelton (ed.), The Oxford Handbook of International Human Rights Law, Oxford 2015, pp. 345-359.

2. V. Horodovenko, V. Pashkov, L. Udovyka, Protection of Patients' Rights in the European Court of Human Rights, Wiadomości Lekarskie, 2018/06. Available at: http://wl.medlist.org/06-2018-13/.

3. Kapelańska-Pręgowska J. European court of human rights ( $\mathrm{gc})$, case of lambert and others v. France, judgment of 5 june 2015, application NO. 46043/14. Comparative Law Review, [S.l.], v. 21, p. 157-174, feb. 2017. ISSN 0866-9449. Available at: <https://apcz.umk.pl/ czasopisma/index.php/CLR/article/view/CLR.2016.005/10962>. Date accessed: 07 Sep. 2019. doi:http://dx.doi.org/10.12775/CLR.2016.005.

4. S. Matthew, The European Court of Human Rights Margin of Appreciation and the Processes of National Parliaments, Human Rights Law Review 2015, vol. 15, no. 4, pp. 745-774.

5. Convention for the protection of human rights and fundamental freedoms as of 04.11.1950 (ratified by Ukraine on 17.07.1997). URL: https://zakon.rada.gov.ua/laws/show/995_004.

6. ECtHR judgment in the case of «Lambert and Others v. France» as of 15.07.2015. URL: http://hudoc.echr.coe.int/eng?i=001-155352. 
7. ECtHR judgment in the case of "Pretty v. United Kingdom" as of 29.04.2002. URL: http://hudoc.echr.coe.int/eng?i=001-60448.

8. Наказ МО3 України «Про затвердження та впровадження медико-технологічних документів зі стандартизації екстреної медичної допомоги» від 05.06.2019 p. № 1269. URL: https://moz.gov.ua/ article/ministry-mandates/nakaz-moz-ukraini-vid-05062019--1269-prozatverdzhennja-ta-vprovadzhennja-mediko-tehnologichnih-dokumentiv-zistandartizacii-ekstrenoi-medichnoi-dopomogi.

9. Convention for the Protection of Human Rights and Dignity of the Human Being with regard to the Application of Biology and Medicine: Convention on Human Rights and Biomedicine as of 04.04.1997. signed by Ukraine on 22.03.2002). URL: https://zakon.rada.gov.ua/laws/ show/994_334.

10.ECtHR judgment in the case of "Jehovah's Witnesses of Moscow and others v. Russia” as of 10.06.2010. URL: http://hudoc.echr.coe.int/ eng?i=001-99221.

11.ECtHR judgment in the case of "Arskaya v. Ukraine" as of 05.03.2014. URL: http://hudoc.echr.coe.int/eng?i=001-138590/

12.ECtHR judgment in the case of "Glass v. The United Kingdom" as of 09.03.2004. URL: http://hudoc.echr.coe.int/eng?i=001-61663.

13. Рішення Липоводолинського районного суду Сумської області від 14.11.2018 p. (справа № 581/625/18). URL: http://reyestr.court.gov.ua/ Review/77899139.

14. Сенюта І.Я. Право людини на медичну допомогу та свобода. URL: $\quad$ https://www.academia.edu/39343553/\%D0\%9F\%D0\%A0\%D0\% 90\%D0\%92\%D0\%9E_\%D0\%9B\%D0\%AE\%D0\%94\%D0\%98\%D0\% 9D\%D0\%98_\%D0\%9D\%D0\%90_\%D0\%9C\%D0\%95\%D0\%94\%D0\% 98\%D0\%A7\%D0\%9D\%D0\%A3_\%D0\%94\%D0\%9E\%D0\%9F\%D0\% 9E\%D0\%9C\%D0\%9E\%D0\%93\%D0\%A3_\%D0\%A2\%D0\%90_\%D0\% A1\%D0\%92\%D0\%9E\%D0\%91\%D0\%9E\%D0\%94\%D0\%90

15. J. Payne-James, I. Wall, P. Dean. Medicolegal Essentials in Healthcare. $2^{\text {nd }}$ edition Cambridge University Press, 26.11.2009. - 284 p.

16. ECtHR judgment in the case of “Z. v. Finland" as of 28.02.1997. URL: http://hudoc.echr.coe.int/eng?i=001-58033.

17.ECtHR judgment in the case of "Avilkina and Others v. Russia" as of 07.10.2013. URL: http://hudoc.echr.coe.int/eng?i=001-120071.

18. ECtHR judgment in the case of "Sidorova v. Russia" as of 28.05.2019. URL: http://hudoc.echr.coe.int/eng?i=001-193260. 
19.Постанова Куп'янського міськрайонного суду Харківської області від 31.05.2017 p. (справа № 628/1177/17). URL: http://reyestr. court.gov.ua/Review/66866596.

20. Постанова Комунарського районного суду м. Запоріжжя від 13.10.2016 р. (справа № 333/4999/16-п). URL: http://reyestr.court.gov.ua/ Review/62006490.

21.Постанова Київського апеляційного суду від 11.04.2019 p. (справа № 761/29995/17). URL: http://reyestr.court.gov.ua/Review/ 81170220

\section{Information about the author:} Senyuta I. Y., Doctor of Laws, Associate Professor, Head of the Department of Medical Law of the Faculty of Post-Graduate Education of Danylo Halytskyi Lviv National Medical University 69, Pekarska str., Lviv, Ukraine 


\title{
RECEPTION OF THE INSTITUTES OF THE CONSTITUTIONAL MECHANISM FOR THE PROTECTION OF HUMAN RIGHTS IN UKRAINE
}

\author{
Verlos N. V.
}

\section{INTRODUCTION}

The current stage of state building in Ukraine is characterized by qualitative changes in the institutional design of the constitutional mechanism of public power where the human rights institutions take the leading place. The process of constitutional and legal modernization in the context of the tendencies of global constitutionalism is accompanied by the reception of ideas, doctrines, concepts and institutions focused on building a democratic organization of the society, ensuring the rule of law, recognition of human rights and freedoms as the highest social value, and optimizing the mechanism of guarantee and protection of human rights and freedoms.

Constitutional-legal modernization is in fact a combination of qualitative changes of the legal system, and this process is therefore impossible without the use of the international experience and the reception of positive achievements of the advanced democracies.

The problem of the reception has become especially relevant in the context of Ukraine's foreign policy towards European integration, which in its turn requires to harmonize, the national legislation of Ukraine with that of the European Union. Thus, in 2014, Ukraine ratified the Association Agreement with the European Union ${ }^{1}$ and finally embarked on the path of European integration and, as stated in the Parliament's statement, «the Verkhovna Rada of Ukraine considers ratification of the Association Agreement between Ukraine and the European Union not only as a stimulating factor for further reforms in Ukraine, but also as a further step on the way to achieving the ultimate goal of European integration gaining full membership in the European Union» ${ }^{2}$. In addition, in

\footnotetext{
${ }^{1}$ Про ратифікацію Угоди про асоціацію між Україною, з однієї сторони, та Європейським Союзом, Європейським співтовариством $з$ атомної енергії і їхніми державами-членами, з іншої сторони: Закон України від 16 вересня 2014 року URL: http://zakon2.rada.gov.ua/laws/show/ 1678-18.

2 Про Заяву Верховної Ради України «Про європейський вибір України»: Постанова Верховної ради України від 16.09.2014 p. URL: http://zakon5.rada.gov.ua/laws/show/ru/1679-18.
} 
accordance with the constitutional changes of 2019, the preamble to the Basic Law proclaims the «irreversibility of the European and EuroAtlantic course of Ukraine» ${ }^{3}$.

As one of the vectors of constitutional and legal reform in the context of the European integration is the improvement of the system of guaranteeing and effectiveness of the constitutional mechanism of human rights protection in Ukraine. This process should be carried out including qualitative updating of existing and the reception of the ways of protecting constitutional human and citizen rights. That is why the issue of the possibility and necessity to continue the reception of the ombudsman institute and the mediation institute is highly topical.

\section{Improving the functioning of the institute of ombudsman based on the foreign experience}

The constitutional development of the modern democratic state, determined by the idea of people-centrism, is oriented towards the search for new institutional forms in the field of human rights protection. The legal nature of public authority is the desire to expand the limits of influence on the society, and it is therefore important to develop an effective deterrent mechanism that will contribute to the prevention of the attacks against the human rights as well as violation of them by the public bodies and their representatives.

In the context of reformation, under the influence of the globalization and internationalization of constitutional law, there is the reception of the institutes that have already been tested over time and function effectively in the foreign countries. The institute of ombudsman is one of the sort in the field of human rights protection. In the context of constitutional and legal modernization, the borrowed institute of ombudsman implemented into the legal system of Ukraine receives qualitatively updated characteristics and requires a comprehensive analysis of the specifics of functioning.

In the process of world democratization, most states try to create new and update existing models of human rights institutions. In Ukraine, the evolution of the institute of ombudsman is underway, and therefore the study of the issue of the place and role of this human rights institute in the constitutional mechanism of human rights protection is quite relevant at the present stage of state building.

\footnotetext{
${ }^{3}$ Про внесення змін до Конституції України (щодо стратегічного курсу держави на набуття повноправного членства України в Європейському Союзі та в Організації Північноатлантичного договору: Закон України від 07.02.2019 p. URL: https://zakon.rada.gov.ua/laws/show/ 2680-19\#n6.
} 
The term «ombuds» comes from Scandinavia, in particular in the translation from medieval Swedish the word «umbud» meant «power» and «authority» ${ }^{4}$. The institute of ombudsman was first established in Sweden in the early 19th century.

In the British Encyclopaedia, the term ombudsman is defined as «... an independent public official investigating citizens» complaints against officials and government authorities» ${ }^{5}$. Foreign researcher D. Rowat defines ombudsman as «an independent and impartial functionary of a legislative body, which oversees the activities of state bodies, considers complaints of citizens in connection with administrative arbitrariness and maladministration» ${ }^{6}$.

In constitutional doctrine there is no consensus on the definition of the ombudsman. For example, some scholars .... this status as an official, in particular, P.P. Shlyakhtun defines the ombudsman as «... a specially elected or appointed official to control the observance of human and civil rights by public authorities, first of all, state executive bodies» ${ }^{7}$. V. Barchuk defines ombudsman as «... a senior official, appointed, as a rule, by the parliament, authorized by the Constitution or a separate law to control the observance of human and civil rights and freedoms by public authorities, sometimes by local self-government bodies and their public officials» ${ }^{8}$.

Other scholars define the term as a «state body». Namely K. O. Zakomorna defines the term of ombudsman as «... a highly authoritative, independent, functionally self-directed, politically neutral state body designed to ensure the exercise of human rights and freedoms of that uses in its work the unconventional criteria for assessing violations of human rights and freedoms committed by public authorities, institutions and organizations, and it affects them morally» ${ }^{9}$. Khamaneva N. Yu. proposes to define the ombudsman as «... an independent public body

${ }^{4}$ Howard Ch.L. The Organizational Ombudsman: origins, roles and operations: a legal guide, Chicago: AmericanBar Association, 2010.642 p.

${ }^{5}$ The World Book Encyclopedia. Field Enterprise as Educational Corporation / Holbert N. Corrol. - N.Y., 1972. V. 14. P. 574.

${ }^{6}$ Rowat D. C. The Ombudsman, Citizcnis Defender: Pref'ase to Second Edition.London: George Allen and Unwin, 1986. - S. XXIV.

${ }^{7}$ Шляхтун П.П. Парламентаризм: словник-довідник. К.: Парламентське вид-во, 2003. С. 86.

${ }^{8}$ Барчук В.Б. Уповноважений Верховної Ради України 3 прав людини як суб'єкт забезпечення національної безпеки: автореф. дисертації ... кандидата юридичних наук 12.00.02. K., 2006. C. 10.

9 Закоморна К.О. Інститут омбудсмана як засіб забезпечення прав і свобод людини та громадянина (порівняльно-правовий аналіз):автореф. дисертації ... кандидата юридичних наук: 12.00.02, Харків, 2000. С. 9. 
directly concerned with the protection of the rights and legitimate interests of a person violated by the acts or omissions of administrative bodies and officials» ${ }^{10}$.

There is also a position according to which the term is defined as a «public authority». A.V. Martseliak notes that the ombudsman is «... appointed by the supreme bodies of state power to be a supervisory, human rights, independent, politically neutral, one-person or collegial body of state authority (official), empowered by the constitution or the law on its own initiative or according to the citizen appeal to control official bodies and officials (especially the executive branch) in terms of respect for rights and freedoms of man and citizen, who usually acts informally at its own discretion and recommends corrective actions committed to the proper protection of these rights and freedoms» ${ }^{11}$.

There is an interpretation of ombudsman as a "public-law institute». Thus, L. V. Golyak, proposes to define «the specialized ombudsman institution as an independent, self-directed, public, as a rule - state or public institute, established for the purpose of ensuring the state (or equivalent public) protection of rights and legal the interests of the persons belonging to vulnerable groups of the population and social groups, the observance of the rights and freedom of these groups and respect by public authorities and local self-government bodies, by their officials, as well as organizations, institutions or other institutions, who specialize in providing public services $^{12}$.

The stated positions of the scientists can be partly agreeable with, but we believe that the ombudsman is an organizationally separate, relatively independent and politically neutral state body whose main task is to promote the protection of human rights and citizens from violations made by public authorities or their officials ${ }^{13}$.

The classic model of ombudsman, which may exist individually or collectively, comes from the Swedish ombudsman established in 1809 and other institutes of ombudsman of the Scandinavian countries (in Finland it was founded in 1919; Denmark - in 1955; Norway - in 1962, and Norway

${ }^{10}$ Хаманева Н. Ю. Место и роль института омбудсмана в системе правового контроля. Правоведение. 1992. № 2. С. 84-88.

${ }^{11}$ Марцеляк О.В. Конституційно-правовий статус інституту омбудсмана: світовий досвід та Українська модель: автореф. дисертації ... доктора юридичних наук 12.00.02. Одеса, 2004. С. 8.

${ }^{12}$ Голяк Л.В. Інститут спеціалізованого омбудсмана: світовий досвід організації та діяльності: дисс. ... канд. юрид. наук. спец. 12.00.02, К., 2009. С. 28.

${ }^{13}$ Верлос Н.В. Омбудсман в механізмі захисту прав людини в Україні: пошук ефективної моделі в контексті запозичення зарубіжного досвіду Вісник Запорізького національного університету: Збірник наукових праць. Юридичні науки. 2018. № 2. С. 25. 
in 1962). The idea was distributed worldwide (New Zealand - 1962 and Australia - 1977). The original idea of the classic model of the ombudsman was far from the ideals of human rights. It was simply an institution focused on ensuring the rule of law in public administration ${ }^{14}$.

The institute of ombudsman was widely spread after the Second World War, which was due to a number of reasons: the world community realized that the maintenance of the world order would be impossible without respect for human rights and freedoms, civic activity increases ${ }^{15}$ and the activities of state structures boosted. Also public authorities were given discretionary powers. It caused the necessity to introduce new mechanisms of protection against arbitrariness of the officials ${ }^{16}$. Then the humanity became aware of the need to establish effective and innovative institutes, one of which was the institute of ombudsman.

Today, the legal Institute of ombudsman is operating effectively in the United Kingdom, Switzerland, Portugal, Australia, Spain, Germany, Italy, the Netherlands, Croatia, the Czech Republic, Bosnia and Herzegovina, Macedonia and others. In the post-socialist countries, the institute of ombudsman was established in Ukraine, the Russian Federation, Georgia, Moldova, Uzbekistan, Azerbaijan, Armenia, Kazakhstan, and others.

In the legal literature, three models of the ombudsman distinguished by their nature and place in the state legal system and the procedure for appointing them are specified: 1) the executive ombudsman (quasiombudsman), appointed by government or president (France, USA); 2) the independent ombudsman is an independent branch of power, the level of which corresponds to the level of the legislative, executive and judicial branches. Appointed by the President or Parliament but not subject to the appointing authority (Portugal, Namibia, Netherlands); 3) the parliamentary ombudsman is part of the legislative system, he or she is appointed (elected) by the parliament and is under control of the parliament ${ }^{17}$.

${ }^{14}$ Cheng, HingYong. The Emergence and Spread of the Ombudsman Institution. Annals of the American Academy of Political and Social Science. 1968. Vol. 377. May. P. 20-30.

${ }^{15}$ Rowat D. The Ombudsman Plan: The Worldwide Spread of an Idea. Rev. 2nd ed. Lanham: University Press of America, 1985. P. 131.

${ }^{16}$ Seneviratne M. Ombudsmen 2000 URL: www.bioa.org.uk/BIOANew/Ombudsmen-2000Mary\%20Seneviratne.pdf.

${ }^{17}$ Мухитдинов Е.Н. Институт омбудсмана (упролномоченного по правам человека) в международном праве: история возникновения и развития в странах мира и Казахстана. ҚР ҰҒА баяндамалары=Доклады Национальной академии наук Республики Казахстан. 2008. № 6. С. 104-105; Новикова А.Е. Институт Уполномоченного по правам человека в Российской Федерации (историко-правовой и теоретико-правовой аспекты): автореф. дисс. ... канд. юрид. наук: спец. 12.00.01; 12.00.02, СПб., 2007. С. 8. 
The parliamentary model of the Ombudsman is considered to be a classic one. However, generally agreeing with the proposed classification of Ombudsman models, it should be noted that the practice of operating in foreign countries is mainly indicative of the real existence of a «combined» model, which simultaneously combines several models of the ombudsman with different status ${ }^{18}$.

Based on three basic models, scientists propose to classify ombudsmen and their legal nature and territorial context by dividing them into: 1) an international ombudsman; 2) the European ombudsman (Commissioner) for Human Rights; 3) national ombudsman; 4) the regional ombudsman; 5) the ombudsman acting locally/local ombudsmen ${ }^{19}$.

In the process of the reception of any institute, it can acquire specific features, which can contribute to the formation of a qualitatively updated model. For example, after borrowing the idea of the institute of ombudsman, the US developed and modified it. Unlike other states where the institute of the ombudsman had some difficulties in the implementation process, which were accompanied by overcoming political, social and legal barriers, in the USA the establishment of the institute of ombudsman received active public support, including from the legal community. As early as 1967, the American Bar Association established an Ombudsman committee within the administrative law section and, in 1971, passed a resolution on the need to develop the ombudsman's concept at both federal and state levels ${ }^{20}$.

Because of borrowing from the classic model of the ombudsman and being perceived by the American legal system, it has transformed, differentiated, and therefore an updated model of this human rights institute emerges as a «quasi-ombudsman».

According to the American researchers, the concept of «quasiombudsman» includes all derivatives of the classic model of the Ombudsman, and its peculiarity is that this institute has spread not only in the field of public-legal relations, but also in the sphere of private legal regulation. For example, the idea of the Institute of Organizational or Corporate Ombudsman, which is a structural unit of an institution/

\footnotetext{
${ }^{18}$ Верлос Н.В. Омбудсман в механізмі захисту прав людини в Україні: пошук ефективної моделі в контексті запозичення зарубіжного досвіду Вісник Запорізького національного університету: Збірник наукових праць. Юридичні науки. 2018. № 2. С. 26.

${ }^{19}$ Новикова А.Е. Институт Уполномоченного по правам человека в Российской Федерации (историко-правовой и теоретико-правовой аспекты): автореф. дисс. ... канд. юрид. наук: спец. $12.00 .01 ; 12.00 .02,2007$. С. $8-9$.

${ }^{20}$ Носырева Е. И. Особенности института омбудсмена в США. Право и политика. 2001. № 9. C. 12-15.
} 
corporation created to resolve conflicts within that organization, in particular between employer and employee, between management personnel and subordinates, has recently been distributed. It was established in such corporations such as IBM, AT\&T, Bank of America, Washington Post ${ }^{21}$, and many universities (university or student ombudsmen) ${ }^{22}$.

However, some American researchers, including J. Lubbers, have stressed the controversy of using the term «ombudsman» to specify existing alternative human rights institutions. In particular, the researcher points out that, in general, the foreign origin of this term is meaningless to most people, but in the United States «... four states, twenty federal agencies and more than 1,000 corporations set up ombudsman offices, using alternative names such as «lawyer», «representative of the citizen» and «mediator» ${ }^{23}$. That is, the borrowed model of the ombudsman in the United States over time lost its identity and ceased to perform the functions that characterize the classic model of the ombudsman. The US experience should be taken into account in the process of adopting a borrowed model of the ombudsman in Ukraine.

Today, the effectiveness of the institute of ombudsman depends on a number of factors, including the development of scientific and technological progress. Namely, as M. Seneviratne notes, the emergence of modern electronic communications technologies, in particular the Internet and personal computer, has great potential for strengthening democratic power ${ }^{24}$. This potential is particularly evident af fot the institute of the ombudsman, which plays an important mediating role in addressing public complaints against members of the public administration. But to what extent will this potential be realized? Of course, the current offices of the ombudsman should take advantage of state-of-the-art electronic technologies to better communicate with the public and improve the quality of service given to the public ${ }^{25}$. In his

${ }^{21}$ Спичак Ю.Г. Модели института омбудсмана на современном этапе. Государственное строительство и право. 2003. Вып. 4. С. 53-62.

${ }^{22}$ Janzen Fred G. A historical study of the campus ombudsman Inunited states higher education: a dissertation Ineducation Submitted to the Graduate Faculty of Texas Tech University in Partial Fulfillment of the Requirements for the Degree of doctor of education, Texas 1971. $254 \mathrm{p}$.

${ }^{23}$ Lubbers Jeffrey S. Ombudsman Offices in the Federal Government - An Emerging Trend Administrative Law and Regulatory Practice. Spring 1998 Volume 2. № 1 URL: https://www.americanbar.org/newsletter/publications/gp_solo_magazine_home/gp_solo_magazine_ index/lubbers.html.

${ }^{24}$ Seneviratne M. Ombudsmen 2000 URL: www.bioa.org.uk/BIOANew/Ombudsmen-2000Mary\%20Seneviratne.pdf.

${ }^{25}$ Hyson S. Adapting the Ombudsman Idea to the 21st Century: Fighting Puffery, E-Government, and Forensic Investigations...University of New Brunswick (Saint Johncampus) URL: https://www.cpsa-acsp.ca/papers-2008/Hyson.pdf. 
study, P. Norris notes that «cyber-optimists hope that the development of the interactive services is a new channel of communication, and that improving the efficiency of digital technologies will help to increase the effectiveness of representative democracy and to establish a relationship between the citizen and the state. In contrast, cyber-pessimists question the ability of governments to adapt to the new environment ${ }^{26}$.

In the national legal sphere, the process of borrowing of the institute of ombudsman began with the adoption of the Constitution of Ukraine (1996) in the form of the classic model of the Parliamentary Ombudsman. In 1997, the Parliament of Ukraine adopted the Law of Ukraine «On the Ukrainian Parliament Commissioner for Human Rights», according to which the Commissioner exercises parliamentary control over the observance of the constitutional rights and freedoms of man and citizen and protection of the rights of everyone in the territory of Ukraine ${ }^{27}$. For that, the Commissioner carries out his or her activities independently of other state bodies and officials and, despite the parliamentary way of formation, his or her powers cannot be terminated or limited in the event of expiration of term of the authority of the Verkhovna Rada of Ukraine or its dissolution (self-dissolution).

In the legal literature, researchers point out that the modern period is characterized by the permanent development of the institutional specialization of ombudsmen and the fulfilment of the functions of ensuring the realization of human rights in various spheres of public relations (public administration, military, penitentiary system, taxes and business, medicine) and various most vulnerable categories of the population (children, persons with disabilities, war veterans, national minorities, migrants, LGBTI community, patients, etc.), the spread of the functions for control and surveillance of the carried out by the regional and municipal authorities and so on ${ }^{28}$.

Recently, a number of institutions have been established in Ukraine according to the initiative both of the President and the government. They are intended to promote the exercise of the powers of the relevant bodies in the field of respect for the rights and legitimate interests of the certain categories of persons. These institutions include the Commissioner of the

${ }^{26}$ Norris P. Digital Divide: Civic Engagement, Information Poverty, and the Internet Worldwide. NewYork: Cambridge University Press, 2001. P. 112.

${ }^{27}$ Про Уповноваженого Верховної Ради України з прав людини: Закон України від 23.12.1997 p. URL:http://zakon2.rada.gov.ua/laws/show/776/97-вр.

${ }^{28}$ Контроль за діяльністю органів публічної влади: національний досвід та міжнародні стандарти: аналітична доповідь / Ю. С. Шемшученко (керівник кол. авт.), О. В. Скрипнюк, Н. Р. Малишева та ін. Київ: Вид-во «Юридична думка», 2018. С. 74-83 
President of Ukraine for Children»s Rights (2011), the Commissioner for the Rights of the Crimean Tatar People (2014), the Commissioner for Rehabilitation of the Participants in Anti-Terrorist Operation Who Received Injuries, contusion, mutilation or Other Illnesses While Participating in Anti-Terrorist Operation (2016).

Accordingly, the Government has instituted such official bodies as the Government Ombudsman for Gender Policy (2017) and the Business Ombudsman (2014). At the same time, there are separate institutions designed to ensure that the rights of the persons with disabilities are respected, both under the President of Ukraine and under the Cabinet of Ministers of Ukraine (namely the Presidential Commissioner for the Rights of Persons with Disabilities (2014) and the Government Commissioner for the Rights of the Persons with Disabilities (2017).

It is worth noting that the introduction and existence of these institutions cannot be attributed to the classic model of the Ombudsman, since they are appointed, fully controlled by the relevant governmental authority (President or Government). That is, such a model for the existence of a system of human rights ombudsmen is likely to be «quasiombudsman».

In the process of finding the optimal model of the Ombudsman, according to the initiative of the President of Ukraine, on 29.08.2019, a bill was submitted to the Verkhovna Rada of Ukraine to amend Articles 85 and 101 of the Constitution of Ukraine (concerning the authorized representatives of the Verkhovna Rada of Ukraine) ${ }^{29}$, according to which it was proposed to change the nature and content of the functional orientation of the activities carried out by Commissioners of the Verkhovna Rada of Ukraine, at the same time expanding the powers of the Parliament regarding their appointment and dismissal.

The need to amend the Constitution of Ukraine, as stated in the explanatory note to the bill, is to «create an effective and efficient parliamentary control mechanism for respect for human and citizen rights and freedoms in Ukraine. It is obvious that one official - the Commissioner of the Verkhovna Rada of Ukraine for Human Rights, who is currently assigned to this function, cannot effectively fulfil his or her duties» ${ }^{30}$.

\footnotetext{
${ }^{29}$ Проект Закону про внесення змін до статей 85 та 101 Конституції України (щодо уповноважених Верховної Ради України) URL: https://w1.c1.rada.gov.ua/pls/zweb2/ webproc4_1?pf3511=66256.

${ }^{30}$ Пояснювальна записка до проекту Закону України «Про внесення змін до статей 85 та 101 Конституції України (щодо уповноважених Верховної Ради України)». URL: https://w1.c1.rada.gov.ua/pls/zweb2/webproc4_1?pf3511=66256.
} 
Of course, the project initiative to improve the functioning of the Parliamentary Ombudsman»s model towards the introduction of functional specialization contains certain advantages and disadvantages. The main benefit is the optimization of the parliamentary oversight mechanism for human rights, and the disadvantage may be the threat of unlimited expansion of the network of specialized parliamentary ombudsmen.

Of course, at the doctrinal level, the issue of the reception of specialized ombudsmen such as the «municipal ombudsman» ${ }^{31}$, «the migration ombudsman» ${ }^{32}$, «the medical ombudsman» ${ }^{33}$ and others has been actively discussed recently. The experience of functioning of the abovementioned officials in foreign countries has allowed to optimize and increase the effectiveness of the whole mechanism of human rights protection.

In general, considering the above-mentioned ideas, it is only necessary to emphasize that during the reformation process in order to improve the effectiveness of the human rights protection mechanism, it is necessary to develop a unified concept of the establishment of the human rights protection system, clearly defining which specific institutions are being proposed, including the list of the ombudsmen and the only model within which they can carry out their functions.

In developing this concept, the experience of functioning of ombudsmen in foreign countries and the domestic practice of state building should be taken into account.

\section{Reception of the institute of mediation in Ukraine: finding the best model through the prism of foreign experience}

Mediation (mediation - intervention between conflicting parties to promote reconciliation, settlement, or compromise ${ }^{34}$ ) is one way of

${ }^{31}$ Батанов О.В. Муніципальний омбудсман як елемент локальної системи захисту прав людини: інституційні та функціональні аспекти. Часопис Київського університету права. 2016. № 1. С. 69.

32 Агєєв О.Д. Конституційно-правовий статус омбудсмана 3 питань міграції: зарубіжні моделі та перспективи запровадження в Україні: автореф. дисс. канд.. юрид. наук спец. 12.00.02. Харків, 2017. С. 4-5.

${ }^{33}$ Наулік Н.С. Інститут медичного омбудсмана в Україні: запровадження та перспективи розвитку. Матеріали II Всеукраїнської науково-практичної конференції «Медичне право України : правовий статус пацієнтів в Україні та його законодавче забезпечення (генезис, розвиток, проблеми і перспективи вдосконалення)». Львів: Львівський Обласний Благодійний Фонд . 2008. С. 211.

${ }^{34}$ Mediation. Merriam-Webster Dictionary. URL: https://www.merriam-webster.com/ dictionary/mediation. 
protecting human rights, which is used to mutually beneficial (consensually) resolve a conflict with the assistance of a third party (mediator).

In the historical aspect, the roots of the Mediation Institute can be found in Phoenician civilization and ancient Babylon. This institute has become widespread in China and Japan. In these countries, up to modern time, the reconciliation of the parties through dialogue is more effective than appealing to the public authorities. The further development of the mediation institute took place in Greece, where mediators were known as «proxenetas», and then in ancient Rome. A legislative regulation of the status of mediators appeared in ancient Rome, starting with Justinian»s Digest (Pandects). In Roman law, they were called differently: «intersunus», «medium», «intersessor», «chilantrorus», «interrorlator», «sonsiliator», «intrrillosut», «interrèsr», and at last mediators ${ }^{35}$.

In the process of developing social relations and finding alternative forms of dispute resolution, the restoration (revival) of the institute of mediation takes place initially in the countries of the Anglo-Saxon system of law in the second half of the twentieth century (USA, UK and Austria). In particular, in 1947, the United States created the Federal Mediation and Conciliation Service (Federal Mediation Conciliation Service) as an independent agency of the US Government. This body is tasked with preventing or minimizing the impact of free-trade labour disputes through mediation, reconciliation and voluntary arbitration ${ }^{36}$. This body functions up to this day and mainly facilitates labor disputes.

In the modern sense, mediation emerged in the United States in the early 1970s. Initially, these were pilot projects on the use of the mediation procedure, but the successful use of mediation was the impetus for the regulatory design of this institute in 2001 into the Uniform Mediation Act (Uniform Mediation Act) ${ }^{37}$.

The reception of the institute of mediation in Europe takes place in the late twentieth and early twenty-first centuries. In particular, the Council of Europe accepts a number of recommendations: Recommendation Rec (98) 1 on mediation in family matters ${ }^{38}$, Recommendation Rec (99) 19 on

35 Ткаченко В.Б., Манухина О.А. Медиация как современный способ решения конфликта.Недвижимость: экономика, управление. 2015. № 1. С. 87.

${ }_{36}$ Federal Mediation and Conciliation Service: official site.URL:https://www.fmcs.gov/ aboutus/our-history/

${ }^{37}$ Uniform Mediation Act (2001). JournalofDisputeResolution. 2003. № 1. P. 14-20.

38 Рекомендация № R (98) 1 Комитета министров государствам-членам касательно медиации в семейных вопросах от 02.01.1998 г. URL: http://www.commonground.org.ua/ lib_law.shtml. 
mediation in criminal matters ${ }^{39}$, Recommendation Rec (2001) 9 on alternative dispute resolution between administrative authorities and private parties ${ }^{40}$, Recommendation Rec (2002) 10 on mediation in civil matters $^{41}$. In 2004, the European Code of Conduct for Mediators was adopted $^{42}$.

In addition, Directive 2008/52 / EC of the European Parliament and of the Council on certain aspects of mediation in civil and commercial matters was adopted in order to better implement the institution of mediation within the framework of European Union legislation ${ }^{43}$.

In the countries of the post-socialist space, the process of the reception of the institute of mediation, which has already received proper legal formulation by adopting a special law (Republic of Kazakhstan (2011), Russian Federation (2010), Georgia (2010), Belarus (2014), etc.), is also gradually taking place.

It is worth emphasizing that in the process of reception of the Institute of Mediation in foreign countries, various models and types of it were formed. And this is quite logical, since the idea borrowed from the donor country (concept, doctrine, institute, etc.) in the process of perception by the recipient country can take on specific forms, features and qualitatively updated interpretation. A number of social, economic, political, organizational, cultural and other factors facilitates this.

Referring to the auestion above, the main models and types of mediation produced during the practical use of foreign countries are highlighted. Thus, I.G. Yasynovskyi, analysing models of mediation in the foreign countries, proposes to specify: 1) judicial mediation (Canada, Germany); 2) lawyer mediation (Italy); 3) notarial mediation (Georgia); 4) professional mediation (USA) ${ }^{44}$.

${ }^{39}$ Рекомендація N R (99) 19 Комітету міністрів Ради Свропи державам - членам Ради, які зацікавлені в організації медіації у кримінальних справах від 15.09.1999 p. URL: http://zakon3.rada.gov.ua/laws/show/994_828.

${ }^{40}$ Рекомендация Rec (2001) 9 Комитета министров государствам-членам об альтернативах судебному разбирательству между административными органами и частными сторонами от 5 сентября 2001 года URL: http://www.csr.ru/document/original_648.stm.

${ }^{41}$ Рекомендация Rec (2002) 10 Комитета Министровгосударствам-членам по медиации в граждански хделах от 18.09.2002 г. URL: http://www.commonground.org.ua/lib_law.shtml.

42 European Code of Conduct for Mediators (2004) URL:http://ec.europa.eu/civiljustice/ adr/adr_ec_code_conduct_en.pdf.

${ }^{43}$ Directive 2008/52/EC of the European Parliament and of the Councilof 21 May 2008 oncertain aspects of mediationin civil and commercial matters.Official Journal of the European Union. № L 136. P. 3-8.

${ }^{44}$ Ясиновський І.Г. Характеристика моделей медіації в розвинутих країнах. Юридичний вісник. 2014. № 4 (33). С. 95. 
Another scientist N.V. Fedorenko identifies the following types of mediation in the international practice: 1) conciliation procedures combined with the state procedure (Great Britain, USA, Japan, Croatia, Greece and Belarus); 2) public mediation (Russia); 3) mediation based on the Harvard method and principle (Hungary, Portugal and Russia; 4) competitive mediation (USA); 5) consolidation (Russia, Switzerland and France); 6) private mediation (USA, UK, Russia and Germany); 7) integrated mediation (Germany) ${ }^{45}$.

Therefore, from the above it becomes clear that in some countries different models and types of mediation exist at the same time. Thus, recognizing the expediency and necessity of the reception of the institute of mediation as an alternative way of resolving legal disputes and an innovative way of protecting constitutional human rights in Ukraine, it is necessary to decide the following. Should the institute of mediation take the form of an extra-judicial protection of human rights, whether it would be a binding part of the justice system, or would it be applied at all stages of the dispute. Also the status of mediators as a person who will directly mediate in the process of conflict resolution, the categories of disputes that can be resolved with the involvement of a mediator, the voluntariness or obligation of mediation, etc. - are relevant at this stage ${ }^{46}$.

For many years, the institute of mediation has actually been operating in Ukraine. However, as the representatives of the Ukrainian Academy of Mediators quite rightly point out, «to this day, Ukrainian mediators work without legal support for their activity, masterfully using the limited possibilities of using mediation within the current legislation» ${ }^{47}$. Recently the NGOs actively investigate foreign experience of mediation and take over the functions of training mediators (NGO "National Association of Mediators of Ukraine” ${ }^{48}$, NGA “Ukrainian Academy of Mediation”, etc.). training of mediators (Odessa Regional Mediation Group (Odessa), Podilsky Mediation Center (Vinnytsia), Ukrainian Mediation Center at

\footnotetext{
${ }^{45}$ Федоренко Н.В. Медиация в России: понятие, характерные особенности. Наука и образование: хозяйство и экономика; предпринимательство; право и управление. 2016. № 3 (70). C. 50-51.

${ }^{46}$ Верлос Н.В. Рецепція інституту медіації як альтернативного способу захисту конституційних прав людини і громадянина в Україні. Вісник Запорізького національного університету: Збірник наукових пращьь. Юридичні науки. 2018. № 1. С. 32.

${ }^{47}$ Крестовська Н., Романадзе Л., Барабаш Т. Медіація в Україні: нюанси законодавчого врегулювання: публікація представників Української академії медіації URL: http://mediation.ua/wp-content/uploads/2017/03/stattya-Mediatsiya-v-Ukrayini-nyuansizakonodavchogo-vregulyuvannya.pdf.

${ }^{48}$ Національна асоціація медіаторів України URL: http://namu.com.ua/ua/info/ mediation/where-to-study.
} 
KMBS (Kyiv), Mediation School of the Academy of Advocacy of Ukraine (Kyiv), etc.).

From the above it can be concluded that today the process of the reception of the institute of mediation in Ukraine has beem intensified, but since this process involves not only borrowing but also perception (implementation) of this institute, it is necessary to establish the necessary legal conditions for its functioning in order to integrate this institute more effectively to the legal system of Ukraine.

The normative basis that provides a real opportunity for the functioning of the institute of mediation is the norm specified by Part 6, Article 55 of the Constitution of Ukraine according to which "everyone has the right in any unlawful way to protect his or her rights and freedoms from violations and unlawful encroachments" ${ }^{9}$. Analyzing the normative content of the abovementioned constitutional prescription, one can speak about the possibility of a person to defend his or her constitutional rights, including through the institute of mediation, of course, if the legislation of Ukraine is not violated in the process of mediation.

In national law, the term «mediation» begins to be used since the adoption of the Law of Ukraine "On Free Legal Aid» (2011). Thus, according to Clause 4 of Part 2 of Article 7 of the abovementioned law, services of free primary legal aid in particular include "providing assistance in ensuring access of a person to secondary legal assistance and mediation" 50 . The Strategy for reforming of the judiciary, the system of justice, and ancillary legal institutions for 2015-2020, approved by the Decree of the President of Ukraine of May 20, 2015, also emphasizes the need to "... expand ways of alternative (extrajudicial) settlement of disputes, in particular, through the practical implementation of the institute of mediation and arbitration" ${ }^{51}$.

Today, the normative definition of the term «mediation» is only enshrined in the State Standard for Social Mediation Services (17.08.2016), namely «mediation is defined as a method of resolving conflicts / disputes by which two or more parties to the conflict / dispute

\footnotetext{
${ }^{49}$ Конституція України від 28 червня 1996 р. (зі змінами) URL: http://zakon5.rada.gov.ua/ laws/show/254к/96-вр.

50 Про безоплатну правову допомогу: Закон України від 02.06.2011 p. URL: http://zakon3.rada.gov.ua/laws/show/3460-17?nreg=3460-

$17 \&$ find $=1 \&$ text $=\% \mathrm{EC} \% \mathrm{E} 5 \% \mathrm{E} 4 \% \mathrm{~B} \% \mathrm{E} 0 \& \mathrm{x}=7 \& \mathrm{y}=6 \# \mathrm{w} 11$.

${ }^{51}$ Стратегія реформування судоустрою, судочинства та суміжних правових інститутів на 2015-2020 роки, затверджена Указом Президента України від 20 травня 2015 року URL: http://zakon3.rada.gov.ua/laws/show/276/2015?nreg=276\%2F2015\&find=1\&text=\%E0\% EB\%FC\%F2\%E5\%F0\%ED\%E0\%F2\%E8\%E2\%ED\%E5\&x=7\&y=5.
} 
are trying to reach an agreement in a structured process involving the conciliator/mediator to resolve it» ${ }^{52}$. In addition, since September 8, 2016, mediation has been included in the list of paid social services ${ }^{53}$. At the same time, mediation covers assistance in conflict resolution, negotiation; working out ways and terms of the conflict resolution ${ }^{54}$.

That is, the evidence indicates an attempt at a subordinate level to regulate this institute under the consideration, whereby mediation is offered to be defined solely as a social service, and therefore its recipient can be only a person or a family, including a foster home, family-type orphanage, legal guardianship and trusteeship, a separate social group, including ethnicity, health status, who are under the influence of difficult circumstances and who require the provision of social services or receive such services ${ }^{55}$. Such an interpretation of mediation significantly narrows its content and significantly limits the range of persons who can use this method to resolve a dispute.

In addition, at the end of 2017, the profession of mediator, namely «specialist in conflict resolution and mediation in the socio-political sphere» is included in the Classifier of the Professions of Ukraine DK 003: $2010^{56}$. Although without the regulatory definition of educational and qualification requirements for the profession «mediator» to include it in the Classifier of the Professions is premature. The analysed legal framework of functioning of the institute of mediation in Ukraine testifies to the subordinate nature of the legal regulation of this institute and to the urgent need for the adoption of a special law on mediation.

Summarizing, it is worth noting that since the reception of mediation is a complex, multidimensional process that involves not only borrowing, but also taking into account the legal system of this institute, more steps must

${ }^{52}$ Про затвердження Державного стандарту соціальної послуги посередництва (медіації): Затверджено Наказом Міністерства соціальної політики від 17.08.2016 № 892 URL: http://zakon2.rada.gov.ua/laws/show/z1243-16.

${ }^{53}$ Про внесення змін до переліку платних соціальних послуг: Постанова Кабінету Міністрів України від 08.09.2016 № 596 URL: http://zakon5.rada.gov.ua/laws/show/596-2016п/paran5\#n5.

${ }^{54}$ Про затвердження Переліку соціальних послуг, що надаються особам, які перебувають у складних життєвих обставинах і не можуть самостійно їх подолати: Наказ Міністерства соціальної політики України від 03.09.2012 p. № 537 URL: http://zakon3.rada.gov.ua/ laws/show/z1614-12.

${ }^{55}$ Про затвердження Державного стандарту соціальної послуги посередництва (медіації): Затверджено Наказом Міністерства соціальної політики від 17.08.2016 № 892 URL: http://zakon2.rada.gov.ua/laws/show/z1243-16.

${ }^{56}$ Зміна № 6 до Класифікатора Професій ДК 003:2010: Затверджена Наказом Міністерства економічного розвитку і торгівлі України від 26.10.2017 р. № 1542 URL: http://www.msp.gov.ua/files/zmina6.pdf. 
be taken to complete it. Therefore, the reception of the institute of mediation as an alternative way of protecting constitutional human and citizen rights in Ukraine is a promising area of reform with a focus on the decentralization of the judiciary, a quality upgrade of the justice system, and a substantial discharge of the courts. However, the reception of the institute of mediation should take into account factors that will facilitate effective integration and take into account the potential threats that may arise during this process.

\section{CONCLUSIONS}

Summarizing the abovementioned, it can be stated that during the process of balanced functioning and development of the Ukrainian statehood, first of all, it is necessary to carry out a systematic constitutional and legal modernization in accordance with a certain foreign policy vector, which also requires a number of changes in the institutional design of the constitutional mechanism of public power. In many ways, this process is accompanied by the reception of certain ideas, concepts, doctrines, institutions and norms in the constitutional law of Ukraine. The reception of the proper institutes of the constitutional mechanism for the protection of human rights, such as the institute of ombudsman and the institute of mediation, deserves special attention.

Today, the combined model of the institute of ombudsman is functioning in Ukraine. On the one hand, the parliamentary model continues to develop, and on the other, an extensive network of «quasiombudsman» institutions begins to operate. That is why during the process of constitutional and legal modernization, while developing a mechanism for the protection of human rights the development of an optimal model of alternative (extrajudicial) human rights institutions should be paid more, including the ombudsmen who would be able to function effectively and facilitate the implementation of the human rights protection mechanism.

In the course of reception of a new institute of mediation for our country it is necessary to carefully consider its implementation in the Ukrainian constitutional and legal reality. Firstly, it means the necessity to consider the type of mediation model. Secondly, it is necessary to take into account the state of the sectoral legislation. Thirdly - gradually forming the public consciousness towards the perception of the new institute for the protection of constitutional human rights, and fourthly, taking into account the peculiarities of the Ukrainian mentality, contribute to building a credit of the civil society's confidence for the new democratic institution. Fifthly, it is necessary to consider human resources obtained by the professional 
mediators and to form a system of institutions that is able to prepare them and take into account other factors that can affect the reception process of the institute of mediation in Ukraine.

Therefore, the reception of the ombudsman and mediation institutions plays an important role in the process of enhancing the effectiveness of the constitutional mechanism for the protection of human rights in Ukraine, and it will also facilitate the implementation of the official course of European integration enshrined in the Constitution of Ukraine. It should be remembered that reception in the constitutional law is a complex multistage process that must be approached cautiously and carefully in order to prevent constitutional and legal distortions.

\section{SUMMARY}

The study has tried to comprehensively analyse the reception of the proper institutes of the constitutional mechanism of human rights protection in Ukraine based on the comparative legal analysis of the foreign experience and positive achievements of the functioning of ombudsman institutions and mediation in the advanced democracies.

An analysis of the overseas practice of the institution of ombudsman confirms that this democratic institution is functioning effectively in most democratic countries. In Ukraine, the reception of the constitutional and legal institute under study is incomplete it is characterized by the search for an optimal model. This process is also facilitated by a project initiative to make amendments to the Constitution of Ukraine.

Unlike the institution of ombudsman, the reception of the institute of mediation is a more complex and multifaceted process, as it is not only about borrowing, but also about the reception of this institute that is new to the Ukrainian legal system. Therefore, the reception of the institute of mediation as an alternative way of protecting constitutional human and citizen rights in Ukraine is a promising direction for the development of state building.

Based on the analysis, the author concludes that the reception of the institute of ombudsman and the institute of mediation plays an important role in the constitutional mechanism of human rights protection in Ukraine in order to increase the effectiveness of their implementation and protection. 


\section{REFERENCES}

1. Про ратифікацію Угоди про асоціацію між Україною, з однієї сторони, та Європейським Союзом, Європейським співтовариством з атомної енергії і їхніми державами-членами, з іншої сторони: Закон України від 16 вересня 2014 p. URL: http://zakon2.rada.gov.ua/ laws/show/1678-18.

2. Про Заяву Верховної Ради України «Про європейський вибір України»: Постанова Верховної ради України від 16.09.2014 р. URL: http://zakon5.rada.gov.ua/laws/show/ru/1679-18.

3. Про внесення змін до Конституції України (щодо стратегічного курсу держави на набуття повноправного членства України в Європейському Союзі та в Організації Північноатлантичного договору: Закон України від 07.02.2019 p. URL: https://zakon.rada.gov.ua/ laws/show/2680-19\#n6.

4. Howard Ch.L. The Organizational Ombudsman: origins, roles and operations: a legal guide, Chicago: American Bar Association, 2010. 642 p.

5. The World Book Encyclopedia. Field Enterprise as Educational Corporation / Holbert N. Corrol. N.Y., 1972. V. 14. P. 574.

6. Rowat D. C. The Ombudsman, Citizcnis Defender: Pref'ase to Second Edition. London: George Allen and Unwin, 1986. S. XXIV.

7. Шляхтун П.П. Парламентаризм: словник-довідник. К.: Парламентське вид-во, 2003. 151 с.

8. Барчук В.Б. Уповноважений Верховної Ради України з прав людини як суб'єкт забезпечення національної безпеки : автореферат дисертації ... кандидата юридичних наук. 12.00.02 - конституційне право; муніципальне право. К., 2006. 21с.

9. Закоморна К.О. Інститут омбудсмана як засіб забезпечення прав і свобод людини та громадянина (порівняльно-правовий аналіз): автореферат дисертації ... кандидата юридичних наук: 12.00.02 конституційне право; муніципальне право. Харків., 2000. 19 с.

10. Хаманева Н. Ю. Место и роль института омбудсмена в системе правового контроля. Правоведение. 1992. № 2. С. 84-88.

11.Марцеляк О.В. Конституційно-правовий статус інституту омбудсмана: світовий досвід та Українська модель. Автореферат дисертації ... доктора юридичних наук 12.00 .02 - конституційне право. Харків, Одеса, 2004. 18 с.

12.Голяк Л.В. Інститут спеціалізованого омбудсмана: світовий досвід організації та діяльності: дисертація на здобуття наукового ступеня кандидата юридичних наук. спец. 12.00.02 конституційне право; муніципальне право. К., 2009. 228 с. 
13.Верлос Н.В. Омбудсман в механізмі захисту прав людини в Україні: пошук ефективної моделі в контексті запозичення зарубіжного досвіду. Вісник Запорізького начіонального університету: Збірник наукових працьь. Юридичні науки. 2018. № 2. С. 23-32.

14. Cheng, Hing Yong. The Emergence and Spread of the Ombudsman Institution. Annals of the American Academy of Political and Social Science. 1968. Vol. 377. May. P. 20-30.

15. Rowat D. The Ombudsman Plan: The Worldwide Spread of an Idea. Rev. 2nd ed. Lanham: University Press of America, 1985. 199 p.

16.Seneviratne M. Ombudsmen 2000 URL: www.bioa.org.uk/ BIOANew/Ombudsmen-2000-Mary\%20Seneviratne.pdf.

17. Мухитдинов Е.Н. Институт омбудсмена (уполномоченного по правам человека) в международном праве: история возникновения и развития в странах мира и Казахстана. баяндамалары=Докладь Наџиональной академии наук Республики Казахстан. 2008. № 6. С. 95-111.

18.Новикова А.Е. Институт Уполномоченного по правам человека в Российской Федерации (историко-правовой и теоретико-правовой аспекты): автореф. дисс. канд. юрид. наук: спец. 12.00.01; 12.00 .02 конституционное право; муниципальное право. СПб., 2007. 24 с.

19. Носырева Е. И. Особенности института омбудсмена в США. Право и политика. 2001. № 9. С. 12-15.

20. Спичак Ю.Г. Модели института омбудсмена на современном этапе. Государственное строительство и право. 2003. Вып. 4. C. 53-62.

21.Janzen Fred G. A historical study of the campus ombudsman In united states higher education: a dissertation. In education Submitted to the Graduate Faculty of Texas Tech University in Partial Fulfillment of the Requirements for the Degree of doctor of education, Texas 1971. $254 \mathrm{p}$.

22. Lubbers Jeffrey S. Ombudsman Offices in the Federal Government - An Emerging Trend? Administrative Law and Regulatory Practice. Spring 1998 Vol. 2. № 1. URL: https://www.americanbar.org/newsletter/ publications/gp_solo_magazine_home/gp_solo_magazine_index/lubbers. html.

23. Hyson S. Adapting the Ombudsman Idea to the 21st Century: Fighting Puffery, E-Government, and Forensic Investigations. University of New Brunswick (Saint John campus) URL: https://www.cpsa-acsp.ca/ papers-2008/Hyson.pdf. 
24. Norris P. Digital Divide: Civic Engagement, Information Poverty, and the Internet Worldwide. New York: Cambridge University Press, 2001. 303 p.

25.Про Уповноваженого Верховної Ради України з прав людини: Закон України від 23.12.1997 p. URL: http://zakon2.rada.gov.ua/laws/ show/776/97-вр.

26. Контроль за діяльністю органів публічної влади: національний досвід та міжнародні стандарти: аналітична доповідь / Ю.С. Шемшученко (керівник кол. авт.), О. В. Скрипнюк, Н. Р. Малишева та ін. Київ: Вид-во «Юридична думка», 2018. С. 74-83.

27.Проект Закону про внесення змін до статей 85 та 101 Конституції України (щодо уповноважених Верховної Ради України) URL: https://w1.c1.rada.gov.ua/pls/zweb2/webproc4_1?pf3511=66256.

28. Пояснювальна записка до проекту Закону України «Про внесення змін до статей 85 та 101 Конституції України (щодо уповноважених Верховної Ради України)» URL:https://w1.c1.rada.gov.ua/pls/ zweb2/webproc4_1?pf3511=66256.

29.Батанов О.В. Муніципальний омбудсман як елемент локальної системи захисту прав людини: інституційні та функціональні аспекти. Часопис Київького університету права. 2016. № 1. С. 65-69.

30.Агєєв О.Д. Конституційно-правовий статус омбудсмана з питань міграції: зарубіжні моделі та перспективи запровадження в Україні: автореф. дисс. ... канд.. юрид. наук спец. 12.00 .02 конституційне право; муніципальне право. Харків, 2017. 21 с.

31.Наулік Н.С. Інститут медичного омбудсмана в Україні: запровадження та перспективи розвитку. Матеріали II Всеукраїнської науково-практичної конференції «Медичне право України : правовий статус пацієнтів в Україні та його законодавче забезпечення (генезис, розвиток, проблеми і перспективи вдосконалення)». Львів: Львівський Обласний Благодійний Фонд. 2008. С. 210-212

32.Ткаченко В.Б., Манухина О.А. Медиация как современный способ решения конфликта. Недвижимость: экономика, управление. 2015. № 1. C. 86-89.

33. Federal Mediation and Conciliation Service: official site. URL: https://www.fmcs.gov/aboutus/our-history.

34. Uniform Mediation Act (2001). Journal of Dispute Resolution. 2003. № 1. Р. 14-20.

35. Рекомендация № R (98) 1 Комитета министров государствамчленам касательно медиации в семейных вопросах от 02.01.1998 г. URL: http://www.commonground.org.ua/lib_law.shtml. 
36. Рекомендація N R (99) 19 Комітету міністрів Ради Європи державам - членам Ради, які зацікавлені в організації медіації у кримінальних справах від 15.09.1999 p. URL: http://zakon3.rada.gov.ua/ laws/show/994_828.

37. Рекомендация Rec (2001) 9 Комитета министров государствамчленам об альтернативах судебному разбирательству между административными органами и частными сторонами от 5 сентября 2001 года. URL: http://www.csr.ru/document/original_648.stm.

38. Рекомендация Rec (2002) 10 Комитета Министров государствам-членам по медиации в гражданских делах от 18.09.2002 г. URL: http://www.commonground.org.ua/lib_law.shtml.

39. European Code of Conduct for Mediators (2004) URL: http://ec.europa.eu/civiljustice/adr/adr_ec_code_conduct_en.pdf.

40. Directive 2008/52/EC of the European Parliament and of the Council of 21 May 2008 on certain aspects of mediation in civil and commercial matters. Official Journal of the European Union. № L 136. P. 3-8.

41.Ясиновський І.Г. Характеристика моделей медіації в розвинутих країнах. Юридичний вісник. 2014. № 4 (33). С. 94-98.

42. Федоренко Н.В. Медиация в России: понятие, характерные особенности. Наука и образование: хозяйство и экономика; предпринимательство; право и управление. 2016. № 3 (70). С. 49-54.

43.Верлос Н.В. Рецепція інституту медіації як альтернативного способу захисту конституційних прав людини і громадянина в Україні. Вісник Запорізького національного університету: Збірник наукових праць. Юридичні науки. 2018. № 1. С. 29-39. С. 32.

44.Крестовська Н., Романадзе Л., Барабаш Т. Медіація в Україні: нюанси законодавчого врегулювання: публікація представників Української академії медіації URL: http://mediation.ua/wpcontent/uploads/2017/03/stattya-Mediatsiya-v-Ukrayini-nyuansizakonodavchogo-vregulyuvannya.pdf.

45.Національна асоціація медіаторів України URL: http://namu.com.ua/ua/info/mediation/where-to-study.

46. Конституція України від 28 червня 1996 р. (зі змінами) URL: http://zakon5.rada.gov.ua/laws/show/254к/96-вр.

47.Про безоплатну правову допомогу: Закон України від 02.06.2011 p. URL: http://zakon3.rada.gov.ua/laws/show/3460-17?nreg= 3460-17\&find=1\&text=\%EC\%E5\%E4\%B3\%E0\&x=7\&y=6\#w11.

48. Стратегія реформування судоустрою, судочинства та суміжних правових інститутів на 2015-2020 роки, затверджена Указом Президента України від 20 травня 2015 року URL: 
http://zakon3.rada.gov.ua/laws/show/276/2015?nreg=276\%2F2015\& find $=1 \&$ text=\%E0\%EB\%FC\%F2\%E5\%F0\%ED\%E0\%F2\%E8\%E2\% $\mathrm{ED} \% \mathrm{E} 5 \& \mathrm{x}=7 \& \mathrm{y}=5$.

49.Про затвердження Державного стандарту соціальної послуги посередництва (медіації): Затверджено Наказом Міністерства соціальної політики від 17.08.2016 № 892 URL: http://zakon2.rada. gov.ua/laws/show/z1243-16.

50.Про внесення змін до переліку платних соціальних послуг: Постанова Кабінету Міністрів України від 08.09.2016 № 596. URL: http://zakon5.rada.gov.ua/laws/show/596-2016-п/paran5\#n5.

51.Про затвердження Переліку соціальних послуг, що надаються особам, які перебувають у складних життєвих обставинах і не можуть самостійно їх подолати: Наказ Міністерства соціальної політики України від 03.09.2012 p. № 537. URL: http://zakon3.rada.gov.ua/ laws/show/z1614-12

52. Про затвердження Державного стандарту соціальної послуги посередництва (медіації): Затверджено Наказом Міністерства соціальної політики від 17.08.2016 № 892. URL: http://zakon2.rada.gov.ua/ laws/show/z1243-16.

53.Зміна № 6 до Класифікатора Професій ДК 003:2010: Затверджена Наказом Міністерства економічного розвитку і торгівлі України від 26.10.2017 p. № 1542. URL: http://www.msp.gov.ua/ files/zmina6.pdf.

\section{Information about the author:} Verlos N. V.,

$\mathrm{PhD}$ in Law, Associate Professor, Department of Constitutional and Labor Law, Zaporizhzhya National University 66, Zhukovsky str., Zaporizhzhia, 69600, Ukraine 


\section{SOCIAL DIALOGUE IN THE FIELD OF LABOUR: DEFINITION AND LEGAL REGULATION}

\section{Chanysheva G. I.}

\section{INTRODUCTION}

In Ukraine, the establishment of social partnership in the field of labour has been associated with the beginning of the 1990s. However, for a long period, the regulatory framework in this area remained unformed due to the lack of specific norms at the legislative level that would establish the legal foundations of the social dialogue. With the adoption of the Framework Law of Ukraine "On the Social Dialogue in Ukraine" of December 23, 2010, these gaps have been eliminated. For the first time in the national legislation the legal principles of organization and procedure of conducting social dialogue in Ukraine were defined with the purpose of elaboration and implementation of state social and economic policy, regulation of labour, social, economic relations and ensuring improvement of the level and quality of life of citizens and social stability in the society.

The development of the theory of social dialogue is one of the current trends in the research of the modern doctrine of labour law. Legal aspects of the social dialogue in the field of labour have been analyzed in the works of V.V. Zhernakov, V.I. Komarnitsky, P.D. Pilipenko, S.M. Prilipko, V.O. Protsevsky, M.V. Sorochishin, G.A. Trunova, O.M.Yaroshenko and others.

At the same time, despite the existence of the legislative definition of the concept, system and mechanism of social dialogue, there are different points of view regarding these categories in the doctrine of labour law.

In order to mark the process of defining and converging of positions, reaching common agreements and making of concerted decisions by the parties to the social dialogue that represent the interests of workers, employers, executive bodies and bodies of local self-government regarding the formation and implementation of state social and economic policies, regulation of labour, social, economic relations, the term "social dialogue" is used in national legislation.

At the same time, it should be noted that social dialogue is a complex multidimensional legal category and cannot be limited to a legislative definition. 
In addition to the legislative definition of the concept of social dialogue in article 1 of the Law of Ukraine "On the Social Dialogue in Ukraine" as a process of defining and converging of positions, reaching mutual agreements and making agreed decisions by the parties to the social dialogue, social dialogue should be considered as: 1) one of the basic principles of legal regulation of labour relations; 2) the system of collective labour relations; 3) as an institute of labour law.

The definition of the social dialogue in the field of labour should be analyzed, first of all as one of the basic principles of labour law, as a system of collective labour relations and as a legal institute in the system of this field.

\section{Social dialogue as one of the basic principles of labour law and the system of collective labour relations}

Principles of labour law are the most important fundamental foundations, the basis of this branch, which permeate the content of its norms and have a universal, general scope. One of the current tasks of the modern doctrine of labour law is a comprehensive study of the system of principles of the industry, based on the international and European labour standards, domestic legal tradition, comparative analysis of Ukrainian labour legislation and the legislation of foreign countries, and the practice of its application by law enforcement agencies. Separate principles of legal regulation of labour relations, including the principle of social dialogue in the field of labour, require special research.

In the context of the codification of the national labour legislation, researchers are tasked to formulate specific proposals regarding the legislative consolidation of the basic principles of legal regulation of labour relations in the draft Labour Code of Ukraine.

In the modern doctrine of labour law, the principles of legal regulation of labour relations are researched in the works of N.B. Bolotina, I.P. Zhigalkin, O.Ya. Lavriv, D.A. Pankov, O.V. Starchuk, G.I. Chanysheva and others. However, the principle of social dialogue in the field of labour has not yet been the subject of a special comprehensive study. Issues that require the attention of researchers should include the question of the definition and content of the above-mentioned principle, its place in the system of principles of labour law.

In the doctrine of labour law, social dialogue is recognized as one of the main principles of legal regulation of labour relations. This conclusion is reached by both the researchers who determine the definition of the 
social dialogue in the field of labour ${ }^{1}$, and the researchers, who study the system of principles of labour law ${ }^{2}$.

As one of the basic principles of modern labour law, the principle of social dialogue in the field of labour may be defined as a guiding idea, a fundamental foundation that expresses the essence, basic characteristics and general orientation of the norms of the legal institutes of collective labour law, as well as particular institutes of individual labour law.

Particular attention should be paid to the importance of the systematic approach to the study of the principles of legal regulation of labour relations that exists in the modern doctrine of labour law. Thus, I.P. Zhigalkin emphasizes that the consistency of the system of the principles of labour law requires:

a) their conformity with each other,

b) a unified approach to their understanding and application,

c) taking into account the nature and content of heterogeneous principles,

d) on the one hand, a differentiated, and on the other hand - an integrated approach to the legal regulation of relations in the field of labour,

e) compliance of the principles of labour law with the true interests of society and the state. Each of the principles can be interpreted and applied only with respect to the essence of the other principles connected with $\mathrm{it}^{3}$.

There is no single approach to the determination of the place of the principle of the social dialogue in the system of principles of labour law. This is explained by the existence of different classifications of the principles of legal regulation of labour relations.

Thus, carrying out the classification of the principles of labour law, I.P. Zhigalkin distinguishes fundamental, general and special principles ${ }^{4}$. Fundamental are those that form the basis of labour law as a whole, which

${ }^{1}$ Чанишева Г.І. Колективні відносини у сфері праці: теоретико-правовий аспект: Монографія. Одеса: Юридична література, 2001. С. 98; Сорочишин М.В. Правові аспекти соціального діалогу у сфері праці: Монографія. Одеса: Юридична література, 2014. С. 91.

${ }^{2}$ Паньков Д.А. Принципи правового регулювання трудових відносин: автореф. дис. ...канд. юрид. наук: 12.00.05. Одеса, 2007. С. 11; Жигалкін І.П. Система принципів трудового права в умовах формування нової правової доктрини України: автореф. дис. ...докт. юрид. наук: 12.00.05. К., 2016. С. 7.

${ }^{3}$ Жигалкін І. П. Система принципів трудового права в умовах формування нової правової доктрини України [Текст]: дис. ... д-ра юрид. наук: 12.00.05 /Східноукраїнський національний університет імені Володимира Даля. Сєвєродонецьк, 2016. С. 166.

${ }^{4}$ Жигалкін І. П. Система принципів трудового права в умовах формування нової правової доктрини України [Текст]: дис. ... д-ра юрид. наук: 12.00.05 /Східноукраїнський національний університет імені Володимира Даля. Сєвєродонецьк, 2016. С. 165-166. 
acts as a mandatory social regulator of labour and related relations and serve as the embodiment of the most important values, inherent to this field of law. These include humanism, social justice and equality. General and special principles, as derivatives from the fundamental principles, ensure their implementation. General principles reflect the specifics of labour law as an independent branch of law, its place and purpose in the national system of law, and determine the focus of its norms. Special principles are the guiding ideas that develop the essence of the norms of one or more institutes (sub-institutes) of labour law.

I.P. Zhigalkin singles out as one of the fundamental principles of labour law the principle of equality and considers it as a basic one for a number of principles of legal regulation of relations in the field of labour, including the principle of social dialogue in the field of labour.

In the doctrine of labour law exists another classification of the principles of legal regulation of labour relations, according to which these principles are divided into four main groups:

1) those that express the policy of the state in the field of legal regulation of the labour market and effective employment;

2) those containing the guidelines in the field of the establishment of working conditions;

3) those that determine the legal regulation of the employment of waged workers;

4) those that reflect the main directions of legal policy in the field of health care and protection of labour rights of workers ${ }^{5}$.

According to this classification, the principle of social partnership is included into the group of principles that determine the establishment of working conditions of employees. At the same time, the emphasis is on the right to participation of workers, employers, their associations in the contractual regulation of labour relations and other directly related relations.

N.B. Bolotina believes that the principle of social partnership is inherent to collective labour law. This principle is complex in its character and composition and includes the following principles-rights: the right of workers and employers for association in order to protect their rights and interests; freedom of association; equality of rights and opportunities.

In our opinion, the above-mentioned approaches to the definition of the place of the principle of social dialogue in the system of principles of labour law carry a narrow understanding of the content of this principle.

${ }^{5}$ Трудовое право: учеб. /Н.А. Бриллиантова и др.; под ред. О.В. Смирнова, И.О. Снигиревой. 3-е изд., перераб. и доп. М.: ТК Велби, Изд-во Проспект, 2007. С. 26. 
One cannot agree with N.B. Bolotina that the principle of social partnership is typical only for collective labour law. This principle is also applied to the regulation of individual labour relations, which has recently become more and more manifest in the norms of such institutes of individual labour law as working time, leisure time, remuneration, health protection of workers at the production site.

If we follow the existing approach in the doctrine of labour law to the definition of the system of principles of labour law as a set of principles of legal regulation of individual labour relations (the principles of individual labour law), the principles of legal regulation of collective labour relations (principles of collective labour law) and the principles inherent to the labour law in general, then in this system the principle of social dialogue in the field of labour belongs to the last group of principles, that is, those which are guiding ideas, fundamental foundations of legal regulation of individual and collective labour relations, which are distinguished in the subject matter of labour law.

At the same time, there is no unity among scholars regarding the definition of the content of the principle of social dialogue in the field of labour. The complex nature of this principle is noted in the literature. According to N.B. Bolotina, the principle of social partnership is complex in nature and composition. The researcher includes in it the following principles-rights: the right of workers and employers to association in order to protect their rights and interests; freedom of association; equality of rights and opportunities ${ }^{6}$.

D.A. Pankov also notes the complex nature of the principle of the social dialogue in the field of labour and includes into its contents the principles of real recognition of the right to collective bargaining and ensuring the participation of employees and their representatives in the management of the organization ${ }^{7}$.

In our opinion, such position of researchers cannot be agreed with. The principles of freedom of association, equality of rights and opportunities, effective recognition of the right to collective bargaining and ensuring the participation of employees and their representatives in the management of the organization in international legal acts are recognized as independent principles in the field of labour and are not considered as elements of the principle of social dialogue. Thus, the ILO Declaration of

\footnotetext{
${ }^{6}$ Болотіна Н.Б. Трудове право України: Підручник. 5-те вид., перероб. і доп. К.: Знання, 2008. C. 197.

7 Паньков Д.А. Принципи правового регулювання трудових відносин: автореф. дис. ...канд. юрид. наук: 12.00.05. Одеса, 2007. С. 11.
} 
18 June 1998 proclaimed four fundamental principles and rights in the field of labour, including freedom of association and the effective recognition of the right to collective bargaining. To the realization of the principle of ensuring the participation of employees and their representatives in the management of an organization are devoted the ILO Recommendation No. 94 on Co-operation at the Level of the Undertaking of 1952 and the ILO Recommendation No. 129 on Communications within the Undertaking of 1967.

Some scholars narrow down the content of the principle of the social dialogue to some extent, linking it only with the collective-contractual regulation of labour relations and the resolution of collective labour disputes ${ }^{8}$.

At the same time, in the ILO practice to the social dialogue are included all types of negotiations, consultations and simply the exchange of information between or among representatives of the government, employers and employees concerning common interests related to economy and social policy. The ILO considers social dialogue to be the most successful means of improvement of living conditions and working conditions and establishment of social justice ${ }^{9}$.

The content of the principle of social dialogue in the field of labour is associated with the participation of workers, employers and their representatives (trade unions, their associations, employers' organizations, their associations) in the contractual regulation of individual and collective labour relations. In a civilized society, it is on the basis of the social dialogue, contractual establishment of working conditions that a balance is struck between the productive and social interests of employers and workers, since centralized regulation alone does not allow this objective to be achieved.

However, the content of the principle of social dialogue should not be reduced only to the participation of workers, employers and their representatives in the establishment of mutually acceptable working conditions. This principle requires the need for constructive cooperation between the parties to the social dialogue at different levels (national, sectoral, territorial, local) to reconcile their objectively opposing interests, finding a compromise, achieving socially meaningful and useful results. This follows from article 1 of the Law of Ukraine "On the Social Dialogue

\footnotetext{
${ }^{8}$ Сорочишин М.В. Правові аспекти соціального діалогу у сфері праці: Монографія. Одеса: Юридична література, 2014. С. 91.

${ }^{9}$ Social Dialogue: all partners for decent work. International Labour Office. Geneva, 2007.
} 
in Ukraine" of December 23, 2010, No. 2862-VI ${ }^{10}$, which formulates the definition of the social dialogue as a process of identifying and converging positions, achieving common agreements and making agreed decisions by parties to the social dialogue, representing interests of employees, employers and executive authorities and bodies of local self-government, on the issues of formation and realization of state social and economic policy, regulation of labour, social and economic relations.

This principle became the basis of legal regulation of creation and operation of social dialogue bodies in the field of labour (National Tripartite Social and Economic Council, sectoral (intersectoral) tripartite or bilateral socioeconomic councils, territorial tripartite socioeconomic councils), different forms of interaction and cooperation of the parties to the social dialogue: information exchange; consultations; conciliation procedures; collective bargaining on the conclusion of collective agreements; realization by representatives of employees of the rights in the field of informing and consulting, as well as other rights related to participation in the making of decisions by the employer; participation of employees and their representatives in the management of the organization; conciliation procedures for resolving labour disputes; implementation of joint control over fulfilment of obligations under collective agreements; participation of employees in the distribution of profit of organizations, etc.

Under the new economic conditions, the content of the principle of social dialogue in the field of labour is increasingly expanding. Specification of this principle is carried out in the norms of various institutes of labour law. These are such institutions of collective labour law as the legal bases for social dialogue in the field of labour, the legal status of labour collectives, the legal status of trade unions, their associations, the legal status of employers' organizations, their associations, collective agreements, the resolution of collective labour disputes (conflicts). Increasingly the principle of social dialogue is reflected in the norms of the institutes of individual labour law, such as, for example, working time, leisure time, remuneration, occupational safety and health of workers in the workplace. It is in the norms of these institutions that the contracting method of regulating labour relations, connected with the conclusion of collective agreements, other agreements, is further developed.

\footnotetext{
${ }^{10}$ Про соціальний діалог в Україні: Закон України від 23.12.2010 № 2862-VI. Відомості Верховної Ради України. 2011. № 28. Ст. 255.
} 
The principle of social dialogue in the field of labour, as well as other principles of legal regulation of labour relations, is not enshrined in the Code of Laws on Labour of Ukraine, which is its essential disadvantage.

This principle is also not mentioned in article 2 "Basic principles of legal regulation of labour relations" of the draft Labour Code of Ukraine. In article 2 prepared for the second reading of the bill of July 24, 2017, there are 15 principles left, most of which are the principles of legal regulation of individual labour relations. The principles of legal regulation of collective labour relations include only the principle of ensuring the right of workers and employers to freedom of association for the representation and protection of their rights and interests. This approach of the drafters of the Labour Code of Ukraine to the system of basic principles of labour law is questionable.

It is also advisable to consider social dialogue in the field of labour as a system of collective labour relations that occur at national, sectoral, territorial and local levels. These are the following types of collective labour relations with: participation of employees in the management of an enterprise, institution, organization; participation of labour collectives in setting and changing working conditions; collective bargaining on the conclusion of collective agreements and collective contracts; implementation of collective agreements and collective contracts and control over their implementation; the activities of trade unions, their associations representing and protecting the rights and interests of employees; the activities of employers' organizations, their associations representing and protecting the rights and interests of employers; the resolution of collective labour disputes (conflicts).

The definition of social dialogue in the field of labour as a system of collective labour relations is consistent with the title of the Sixth book "Collective Labour Relations" of the Draft Labour Code of Ukraine.

Collective labour relations may be defined as volitional social relations, regulated by the norms of labour law, within which their subjects exercise collective labour rights and perform their corresponding duties in accordance with the current labour law.

Collective labour relations are characterized by general features of legal relations, formulated in the theory of law. Specific features of collective labour relations include the following: they arise and function at all levels of the social dialogue - national, sectoral, territorial and local; constitute a tripartite or bilateral legal relations; their subjects are, as a rule, collective entities (except for the local level, at which according to article 4 of the Law of Ukraine "On the Social Dialogue in Ukraine" it is 
provided for the participation of the employer and the employee's representative); their legal content is made up of collective labour rights and corresponding responsibilities; in these relationships collective (corporate) interests are realized; there is representation of the interests of workers, employers, the state, making it different from the institution of representation in civil law.

The legal content of collective labour relations is made up of the rights and duties of their subjects. The specificity of the content of the specified legal relationships is that collective labour rights of employees, employers (their representatives) are realized within their framework. The international legal acts enshrine such collective labour rights as the right of workers and employers to freedom of association, the right of employees to participate in the management of the organization, the right of workers and employers to collective bargaining and the conclusion of collective agreements, the right of workers and employers (their representatives) on information and consultations, the right of workers and employers to resolve collective labour disputes (conflicts) (European Social Charter (revised) provides for the right of workers and employers collective action, including the right to strike), the right of employees to receive information and advice during collective dismissal.

Conclusion on the relationship of collective labour relations with legal relations from social dialogue in the field of labour is one of the leading in the theory of collective labour relations. Social dialogue in the field of labour should be considered as a system of collective labour relations between workers, employers and their representatives, executive bodies, other subjects of these relations, which arise in the process of realization of their collective labour rights and interests. Legal relations within the social dialogue in the field of labour actually exist as a specific kind of collective labour relations.

\section{Social dialogue as an institute of labour law}

In the legal literature, two approaches to defining the legal concept of social partnership are the most common. The first approach is to define social partnership as a legal institute, although the views of scholars on the content and structure of this institute differ ${ }^{11}$. The second approach is related to a broader understanding of social partnership, in connection with

${ }^{11}$ Трудовое право России /под ред. А.М. Куренного. М.: Юристъ, 2006. С. 125; Пашков А.С. Избранные труды по трудовому праву. СПб : Изд. Дом СПб гос. ун-та, изд-во юрид. фак., 2006. С. 436; Трудовое право: учебник для бакалавров / отв. ред. К.Н. Гусов. М.: Проспект, 2015. С. 155. 
which the concept is considered in several meanings (aspects), and the views of the proponents of this approach do not coincide.

Thus, in the Great Encyclopedic Legal Dictionary, social partnership is defined in two respects as: 1) a system of developed relationships between employees, employers, as well as the state on the basis of cooperation, compromises, agreed decisions on social and labour relations; 2) the principle of social policy of the state, which ensures the fair distribution of material resources between the parties of social relations in a market economy ${ }^{12}$.

According to S.M. Prilipko, O.M. Yaroshenko, N.M. Klymenchuk, social partnership can be characterized as: a) a legal institute, which is a set of legal norms, governing a group of interrelated relations between employees, employers and the state; b) a legal principle that reflects the guiding idea, characterizing the patterns of reconciliation of interests of the subjects of social partnership; c) social relations between employees, employers and the state, in which each of their participants acts as the bearer of subjective rights and responsibilities; d) a legal mechanism in the regulation of social and labour relations ${ }^{13}$.

According to A.M. Lushnikov and M.V. Lushnikova, social partnership should be viewed as a legal mechanism for regulation of collective relations, which includes the regulatory and protective parts ${ }^{14}$. Researchers point out that collective (social partnership) relations arise with regard to collective bargaining and the conclusion of collective agreements and contracts; participation of employees and their representatives in the management of an organization, trade union representation and protection of workers' rights, mutual consultations, negotiations on the regulation of labour relations. This is covered by the regulatory part of the legal mechanism of social partnership. The protective part of the legal mechanism of social partnership includes the conciliation procedure for the settlement of collective labour disputes, including the right to strike.

V.A. Safonov defines social partnership as a way of regulating social and labour relations between employees (their representatives) and employers (their representatives), based on mutual consideration of

12 Великий енциклопедичний юридичний словник /За редакцією акад. НАН України Ю.С. Шемшученка. К.: ТОВ «Видавництво «Юридична думка», 2007. С. 825-826.

${ }^{13}$ Прилипко С.М., Ярошенко О.М., Клименчук Н.М. Колективні угоди як результат соціального партнерства (сучасний стан і перспективи розвитку ). Х.: Вид-во «ФІНН», 2011. C. 11.

14 Лушников А.М., Лушникова М.В. Курс трудового права: Учебник: В 2 т. Т. 2. Коллективное трудовое право. Индивидуальное трудовое право. Процессуальное трудовое право. М.: Статут, 2009. С. 40. 
interests of each party, respect for those interests and refusal of forceful ways of interaction ${ }^{15}$.

Other definitions of the legal concept of the social partnership in the field of labour are formulated by modern researchers: the legal mechanism of regulation of collective relations ${ }^{16}$; element of the mechanism of protection of labour rights of workers ${ }^{17}$; method and mechanism of regulation of social-labor relations and dispute settlement between employees and employers ${ }^{18}$ etc.

In the legislation of most post-Soviet states, the concept of social partnership is defined as a system of relations between employees (employees' representatives), employers (employers' representatives), and bodies of state power. Thus, in accordance with article 1 of the Labour Code of the Republic of Kazakhstan of November 23, 2015 social partnership is a system of relations between employees (employees' representatives), employers (representatives of employers), bodies of state power, aimed at ensuring the harmonization of their interests in matters of regulation of labour relations and other relations directly related to employment. A similar definition of the concept of social partnership is provided in article 23 of the Labour Code of Russian Federation of December 30, 2001.

Close in the content to the above mentioned formulation was the definition of social partnership in part 1 of article 40 of the Labour Code of the Republic of Lithuania of 4 June 2002 as a system of relations between representatives of employees and employers and their organizations, and in some cases established by this Code and other laws also state institutions, with the means of which it is necessary to reconcile the interests of the subjects of labour relations. However, the definition of social partnership is not provided in the new Labour Code of the Republic of Lithuania of 14 September 2016. In article 161, Section I "General Provisions" of Part III of "Collective Labour Relations" only the aim and principles of social partnership in labour relations were set out.

The concept of social partnership in article 352 of the Labour Code of the Republic of Belarus of July 26, 1999 is different from the definitions,

\footnotetext{
${ }^{15}$ Социальное партнерство: учебник для бакалавриата и магистратуры /В.А. Сафонов. М.: Издательство Юрайт, 2015. С. 36.

${ }^{16}$ Жернаков В.В. Договірне регулювання соціально-трудових відносин. Вісник Академії правових наук України. 2010. № 4. С. 237.

17 Сошникова Т.А. Социальное партнерство как важнейший механизм защиты трудовых прав работников. Труды Ин-та гос-ва и права Рос. акад. наук. 2008. № 1. С. 108.

${ }^{18}$ Гордон Л.А. На пути к социальному партнерству. Развитие социально-трудовых отношений в современной России. М.: ИНФРА, 1998. С. 48-57.
} 
provided above. According to the latter definition social partnership is a form of interaction between bodies of public administration, employers' associations, trade unions and other representative bodies of employees, authorized in accordance with the acts of the law to represent their interests (subjects of social partnerships) during the development and implementation of the socio-economic policy of the state, based on taking into account the interests of different sections and groups of society in the social and labour sphere through negotiations, consultations, nonconfrontation and s absense of social conflicts.

The presence of a large number of definitions of the legal concept of social partnership indicates its complexity and versatility.

In specifying the definition of this legal category, it should be taken into consideration that the term "social partnership" has been replaced in the national legislation by the term "social dialogue", as well as the fact that the term "social dialogue" is used in international legal practice, in particular in the acts and publications of the ILO, more often than the "social partnership".

The term "social dialogue" was introduced into national legislation by the Decree of the President of Ukraine "On the Development of Social Dialogue in Ukraine" of December 29, 2005. Legal foundations of the organization and procedure for conducting social dialogue were later established in the Law of Ukraine "On the Social Dialogue in Ukraine" of December 23, 2010. In the Law of Ukraine "On Employers' Organizations, their Associations, Rights and Guarantees of Their Activities" of June 22, 2012 No. 5026-VI the term "social dialogue" is used instead of the term "social partnership".

National legislation is characterized not only by the use of the term "social dialogue" instead of the term "social partnership", but also by defining the content of the term.

Some authors hold the view that social dialogue and social partnership are two separate concepts. As V.O. Protsevsky specifies, social dialogue is only a process of defining and converging the positions of its participants, it is consultation and negotiation; the achievement of joint agreements and the adoption of agreed decisions by the subjects of legal relations in the field of wage labour constitute social partnership ${ }^{19}$. Analyzing the principles of social dialogue and its parties the researcher believes that there is a transformation of social dialogue into social partnership.

19 Процевський В.О. Приватно-правове та публічно-правове регулювання соціальнотрудових відносин: монографія. Х.: ХНАДУ, 2012. С. 280. 
It seems that in this case there is a dispute solely about the terms, not the essence of this legal phenomenon. In general, the discussion of the differences between the terms "social dialogue" and "social partnership" seems unjustified and unpromising. Since the term "social dialogue" ha been used in national legislation for more than 10 years, the representatives of the doctrine should also adhere to the single terminology, even if the term "social partnership" is more appropriate in the view of some scholars.

In our opinion, in addition to the legislative fixation of the definition of social dialogue in article 1 of the Law of Ukraine "On the Social Dialogue in Ukraine" as a process of defining and converging positions, reaching common agreements and making agreed decisions by the parties to the social dialogue, social dialogue can be considered as: 1) one of the basic principles of legal regulation of labour relations; 2) the system of collective labour relations; 3) as an institute of labour law.

As a principle of legal regulation of labour relations, the principle of social dialogue in the field of labour belongs to the fundamental guiding principles that determine the content of modern labour law and directions for its further development. As one of the basic principles of legal regulation of labour relations, the principle of social dialogue in the field of labour should be envisaged in article 2 of the draft Labour Code of Ukraine.

It is also advisable to consider social dialogue in the field of labour as a system of collective labour relations that occur at national, sectoral, territorial and local levels. These are the following types of collective labour relations with: participation of employees in the management of an enterprise, institution, organization; participation of labour collectives in setting and changing working conditions; collective bargaining on the conclusion of collective agreements and collective agreements; implementation of collective agreements and collective agreements and control over their implementation; the activities of trade unions, their associations representing and protecting the rights and interests of employees; the activities of employers' organizations, their associations representing and protecting the rights and interests of employers; the resolution of collective labour disputes (conflicts).

The definition of social dialogue in the field of labour as a system of collective labour relations is consistent with the title of the Sixth book “Collective Labour Relations" of the draft Labour Code of Ukraine.

The legislation of Ukraine on social dialogue in the field of labour is based on the Constitution of Ukraine and consists of international treaties 
ratified by Ukraine, the Code of Laws on Labour of Ukraine, laws of Ukraine "On the Social Dialogue in Ukraine", "On Collective Agreements", "On Remuneration" , "On the procedure for resolving collective labour disputes (conflicts)", "On trade unions, their rights and guarantees of activity", "On the organization of employers, their associations, rights and guarantees of their activities", by-laws, acts of social dialogue (collective agreements, collective contracts, other acts).

The norms contained in these normative acts, in their entirety, correspond to the characteristics of the institute of law. In the theory of law, an institute of law is defined as an objectively distinct within a single branch or several branches of law set of interrelated legal norms, governing a small group of specific family of relationships ${ }^{20}$. A legal institute is characterized by a general content of legal norms, a semantic connection between them, a logical unity that causes them to be separated within a branch of law or, as an exception, between several branches of law.

As an independent institute of labour law, social dialogue in the field of labour is a set of legal norms that enshrine concepts, basic principles of social dialogue, levels and parties, criteria of representativeness for the subjects of trade union side and employers' side, forms of social dialogue, legal status of bodies of social dialogue, control and responsibility of the parties to social dialogue.

Defining social partnership as a legal institute, researchers have not reached a consensus on the place of this institute in the system of labour law. In the doctrine social partnership is considered as a new institute of the general part of labour law ${ }^{21}$ or as a new general institute of "social partnership", which has a complex structure and includes a sub-institute of collective contracts, collective agreements (O.V. Smirnov and others) ${ }^{22}$.

S.M. Prylypko, O.M. Yaroshenko, N.M. Klymenchuk define the content of the legal institute of social partnership as a set of legal norms governing a group of interrelated relations between employees, employers and the state. However, at the same time, researchers do not specify what the relations in question are, and do not determine the place of this institute in the system of labour law.

Social dialogue in the field of labour should be recognized an independent institute of labour law. It is an integral part of the collective

\footnotetext{
${ }^{20}$ Общетеоретическая юриспруденция: учебный курс: учебник / под ред. Ю.Н. Оборотова. О.: Феникс, 2011. С. 115.

${ }^{21}$ Трудовое право России: Учебник для вузов / Под ред. С.Ю. Головиной, М.В. Молодцова. М.: Изд-во Норма, 2010. С. 116.

22 Комментарий к Трудовому кодексу РФ: постатейный / Под ред. О.В. Смирнова. 2-е изд., перераб. и доп. М.: Проспект (ТК Велби), 2005. С. 80-81.
} 
labour law as a structural element in the system of labour law of Ukraine. Collective labour law, in addition to the specified institute, includes the following institutes: legal status of labour collectives; legal status of trade unions, their associations; the legal status of employers' organizations, their associations; collective agreements and collective contracts; the resolution of collective labour disputes (conflicts).

\section{CONCLUSIONS}

As one of the basic principles of modern labour law, the principle of social dialogue in the field of labour is a guiding idea, a fundamental foundation that expresses the essence, basic characteristics and general orientation of the norms of the legal institutes of collective labour law, as well as specific institutes of individual labour law.

In the system of principles of labour law, the principle of social dialogue in the field of labour belongs to the principles inherent to labour law in general, that is, those that are guiding ideas, the basic principles of legal regulation of individual and collective labour relations, which are distinguished in the subject matter of labour law.

The principle of the social dialogue in the field of labour is the fundamental foundation of the legal regulation of the participation of employees, employers and their representatives in the contractual regulation of individual and collective labour relations, the creation and operation of the bodies of the social dialogue, various forms of interaction and cooperation of the parties to the social dialogue at different levels: information exchange; consultations; conciliation procedures; collective bargaining on the conclusion of collective agreements; realization by the representatives of employees of the rights in the field of informing and consulting, as well as other rights related to participation in the adoption of decisions by the employer; participation of employees and their representatives in the management of the organization; conciliation procedures for resolving labour disputes; implementation of joint control over fulfilment of obligations under collective agreements; participation of employees in the distribution of profit of organizations, etc.

The list of principles enshrined in article 2 of the draft Labour Code of Ukraine does not include some principles that should indeed be recognized as the starting point, the main provisions of the legal regulation of labour relations. These include the principle of social dialogue in the field of labour, which needs to supplement the list of basic principles of legal regulation of labour relations in article 2 of the draft Labour Code of Ukraine. 
It is also advisable to consider social dialogue in the field of labour as a system of collective labour relations that arise at the national, sectoral, territorial and local levels. These are the following types of collective labour relations regarding: the participation of employees in the management of an enterprise, institution, organization; participation of labour collectives in setting and changing working conditions; collective bargaining on the conclusion of collective agreements and collective contracts; implementation of collective agreements and collective contracts and control over their implementation; the activities of trade unions, their associations representing and protecting the rights and interests of employees; the activities of employers' organizations, their associations representing and protecting the rights and interests of employers; the resolution of collective labour disputes (conflicts).

Social dialogue in the field of labour is an independent institute of labour law. It is an integral part of collective labour law as a structural element in the system of labour law of Ukraine. Collective labour law, in addition to the specified institute, includes the following institutes: legal status of labour collectives; the legal status of trade unions, their associations; the legal status of employers' organizations, their associations; collective agreements and collective contracts; the resolution of collective labour disputes (conflicts).

The contents of the institute is formed by the legal norms that enshrine the definition, basic principles of social dialogue, levels and parties, criteria of representativeness for the subjects of trade union side and employer side, forms of social dialogue implementation, legal status of social dialogue bodies, control and responsibility of the parties to the social dialogue.

The current Labour Code of Ukraine does not contain any special rules on the social dialogue in the field of labour. Unfortunately, a separate chapter 1 "Social Dialogue", was excluded from Book 6 "Collective Labour Relations" of the draft Labour Code of Ukraine № 1658. Despite the importance of social dialogue, its legal foundations are not enshrined in the draft law, which is something we cannot agree with. The position of the developers of the Draft law is not consistent with the structure and content of the new labour codes adopted in post-socialist countries, which include separate sections (chapters) on social partnership.

It seems appropriate to change the name of the Book 6 of the draft Labour Code of Ukraine and to call it "Social Dialogue in the Field of Labour. Collective Labour Relations». In two separate articles of this Book it is necessary to consolidate the definition, principles and tasks of the social dialogue, as well as the system and organization of the social dialogue in the field of labour. 


\section{SUMMARY}

The concept of social dialogue in the field of labour should be considered as one of the basic principles of labour law, as a system of collective labour relations and as a legal institute in the system of this field.

The concept and the content of the principle of the social dialogue in the field of labour are defined. The place of the principle of the social dialogue in the field of labour in the system of principles of labour law is ascertained. Proposals on the implementation of the principle of the social dialogue in the field of labour in the current Code of Laws on Labour of Ukraine, draft Labour Code of Ukraine are introduced.

Social dialogue in the field of labour is a system of collective labour relations that arise at the national, sectoral, territorial and local levels. These are the following types of collective labour relations regarding: the participation of employees in the management of an enterprise, institution, organization; the participation of labour collectives in setting and changing of working conditions; collective bargaining on the conclusion of collective agreements and collective contracts; implementation of collective agreements and collective contracts and control over their implementation; the activities of trade unions, their associations regarding representation and protection of the rights and interests of employees; the activities of employers' organizations, their associations representing and protecting the rights and interests of employers; the resolution of collective labour disputes (conflicts).

The social dialogue in the field of labour as an institution of labour law is determined. The contents of the indicated institute and its place in the system of modern labour law in Ukraine are identified. As an independent institute of labour law, social dialogue in the field of labour is a set of legal norms that enshrine definition, basic principles of social dialogue, levels and parties, criteria of representativeness for the subjects of trade union side and employers' side, forms of social dialogue, legal status of bodies of social dialogue, control and responsibility of the parties to social dialogue. Proposals on fixation of the norms of the institute of social dialogue in the field of labour in the draft Labour Code of Ukraine are introduced. 


\section{REFERENCES}

1. Чанишева Г.І. Колективні відносини у сфері праці: теоретикоправовий аспект: Монографія. Одеса: Юридична література, 2001. 328 c.

2. Сорочишин М.В. Правові аспекти соціального діалогу у сфері праці: Монографія. Одеса: Юридична література, 2014. 208 с.

3. Паньков Д.А. Принципи правового регулювання трудових відносин: автореф. дис. ... канд. юрид. наук: 12.00.05. Одеса, 2007. 20 с.

4. Жигалкін І.П. Система принципів трудового права в умовах формування нової правової доктрини України: автореф. дис. ... докт. юрид. наук: 12.00.05. К., 2016. 40 с.

5. Жигалкін І. П. Система принципів трудового права в умовах формування нової правової доктрини України [Текст]: дис. ... д-ра юрид. наук: 12.00.05 / Східноукраїнський національний університет імені Володимира Даля. Сєвєродонецьк, 2016. 442 с.

6. Трудовое право: учеб. /Н.А. Бриллиантова и др.; под ред. О.В. Смирнова, И.О. Снигиревой. 3-е изд., перераб. и доп. М.: ТК Велби, Изд-во Проспект, 2007. 600 с.

7. Болотіна Н.Б. Трудове право України: Підручник. 5-те вид., перероб. і доп. К.: Знання, 2008. 860 с.

8. Social Dialogue: all partners for decent work. International Labour Office. Geneva, 2007.

9. Про соціальний діалог в Україні: Закон України від 23.12.2010 № 2862-VI. Відомості Верховної Ради України. 2011. № 28. Ст. 255.

10. Трудовое право России /под ред. А.М. Куренного. М.: Юристъ, 2006. $496 \mathrm{c}$.

11.Пашков А.С. Избранные труды по трудовому праву. СПб : Изд. Дом СПб гос. ун-та, изд-во юрид. фак., 2006. 520 с.

12. Трудовое право: учебник для бакалавров / отв. ред. К.Н. Гусов. М.: Проспект, 2015. 632 с.

13. Великий енциклопедичний юридичний словник / За редакцією акад. НАН України Ю.С. Шемшученка. К.: ТОВ «Видавництво «Юридична думка», 2007. 992 с.

14.Прилипко С.М., Ярошенко О.М., Клименчук Н.М. Колективні угоди як результат соціального партнерства (сучасний стан i перспективи розвитку ). Х.: Вид-во «ФІНН», 2011. 256 с.

15.Лушников А.М., Лушникова М.В. Курс трудового права: Учебник: В 2 т. Т. 2. Коллективное трудовое право. Индивидуальное трудовое право. Процессуальное трудовое право. М.: Статут, 2009. $1151 \mathrm{c}$. 
16.Социальное партнерство: учебник для бакалавриата и магистратуры / В.А. Сафонов. М.: Издательство Юрайт, 2015. 395 с.

17.Жернаков В.В. Договірне регулювання соціально-трудових відносин. Вісник Академії правових наук України. 2010. № 4. С. 237.

18. Сошникова Т.А. Социальное партнерство как важнейший механизм защиты трудовых прав работников. Труды Ин-та гос-ва $u$ права Рос. акад. наук. 2008. № 1. С. 108.

19.Гордон Л.А. На пути к социальному партнерству. Развитие социально-трудовых отношений в современной России. М.: ИНФРА, $1998.256 \mathrm{c}$.

20.Процевський В.О. Приватно-правове та публічно-правове регулювання соціально-трудових відносин: монографія. Х.: ХНАДУ, 2012. $330 \mathrm{c}$.

21.Общетеоретическая юриспруденция: учебный курс: учебник / под ред. Ю.Н. Оборотова. О.: Феникс, 2011. 436 с.

22. Трудовое право России: Учебник для вузов / Под ред. С.Ю. Головиной, М.В. Молодцова. М.: Изд-во Норма, 2010. 704 с.

23. Комментарий к Трудовому кодексу РФ: постатейный / Под ред. О.В. Смирнова. 2-е изд., перераб. и доп. М.: Проспект (ТК Велби), 2005. 784 c.

Information about the author:

Chanysheva G. I.,

Doctor of Legal Sciences, Professor, Corresponding Member of the National Academy of Legal Sciences of Ukraine, Dean of the Socio-Legal Faculty, National University “Odessa Law Academy” 2, Academychna str., Odessa, 65009, Ukraine 


\title{
INTERACTION OF THE UKRAINE NATIONAL POLICE WITH OTHER SUBJECTS OF PUBLIC SECURITY IN THE CONDITIONS OF THE UNITED FORCES OPERATIONS
}

\begin{abstract}
Abroskin V. V.
INTRODUCTION

Issues of interaction of the National Police of Ukraine with state authorities, local self-government bodies and the public are an important component of effective work during holding joint events joint actions to ensure the protection of public order and public security, minimize administrative offenses, taking measures to enhancing the effectiveness of counteraction to crime in the area of the of the united forces operations.

For our country, the issue of cooperation between law enforcement and other public authorities became especially relevant with the beginning of armed aggression by the Russian Federation in the spring of 2014, which violated the sovereignty, independence and territorial integrity of our state. In connection with this, on 14.04.2014 the decision of the National Security and Defense Council of Ukraine «On urgent measures to overcome the terrorist threat and preservation of the territorial integrity of Ukraine» was put into effect. The date is considered the start of an antiterrorist operation $^{1,2}$.

On April 30, 2018, the President of Ukraine signed the Order «On the start of the united forces operations with implementation of national security and defense the suppression of armed aggression of the Russian Federation in the Donetsk and Luhansk Regions». According to the order, from 14:00 on April 30, 2018, started the united forces operations according to plan of the united forces operations. Subsequently, the President signed the order of the Commander-in-Chief «On approval of the provision about the Joint Operational Headquarters UFU» ${ }^{3}$.
\end{abstract}

\footnotetext{
${ }^{1}$ Про рішення Ради національної безпеки і оборони України від 13 квітня 2014 року «Про невідкладні заходи щодо подолання терористичної загрози і збереження територіальної цілісності України» : Указ Президента України від 14 квіт. 2014 р. № 405/204. URL: https://zakon.rada.gov.ua/laws/show/405/2014 (дата звернення: 20.11.2019).

${ }^{2}$ Про рішення Ради національної безпеки і оборони України від 30 квітня 2018 року «Про широкомасштабну антитерористичну операцію в Донецькій та Луганській областях» : Указ Президента України від 30 квіт. 2018 р. № 116/2018. URL: https://zakon5.rada.gov.ua/ laws/show/116/2018 (дата звернення: 21.11.2019).

${ }^{3}$ Ibid.
} 
However, despite the fact that the united forces operations has been underway for a long time, there are still many problems, one of which is the interaction of the National Police of Ukraine with state authorities, local authorities and the public in the area of the united forces operations. At present, such interaction is not going through the best of times due to insufficient funding of the Ministry of Internal Affairs of Ukraine, as well as due to constant personnel changes of the heads of the National Police of Ukraine. All this leaves a negative impact on the establishment of a new European-level law enforcement system.

According to Art. 2 of the Law of Ukraine «On National Police» the issue of ensuring public security is one of the key spheres of implementation of the tasks of the police, including its interaction ${ }^{4}$, while the legal principles of cooperation in the conditions of the united forces operations are defined in the Law of Ukraine «On the fight against terrorism» ${ }^{5}$. However, there was not enough one law to coordinate all subjects in the fight against terrorism, as well as to solve serious problems.

The review of legal literature gives grounds to claim that the theoretical and practical issues of the organization of interaction both in general and certain aspects of it have repeatedly been the subject of scientific researches by O.M. Bandurka, O.I. Bezpalova, Y.P. Bytyak, I.P. Golosnichenko, O.M. Klyueva, V.K. Kolpakova, A.T. Komzyuka, V.M. Plishkina, V.V. Sokurenko, O.Y. Sinyavskaya, V.O. Shamrai, Y.V. Kharchenko and others. However, works of these researchers did not take into account the peculiarities of the interaction of the National Police with other subjects of public security entities in the context of the united forces operations, which confirms the relevance of the research of these issues.

Thus, one of the most pressing problems of interaction of the National Police of Ukraine with the state authorities, local self-government bodies and the public in the area of the united forces operations. Thus, this remains the absence of a general legal act that would regulate the interaction of public administration entities and the sequence of concerted actions during the execution of both joint and separate tasks in the area of the united forces operations.

\footnotetext{
${ }^{4}$ Про Національну поліцію : Закон України від 02 липн. 2015 р. № 580 - VIII. URL: https://zakon.rada.gov.ua/laws/show/580-19 (дата звернення: 21.11.2019).

${ }^{5}$ Про боротьбу з тероризмом : Закон України від 20 бер. 2003 р. № 638-IV. URL: https://zakon.rada.gov.ua/laws/show/638-15/ed20090611 (дата звернення: 23.11.2019).
} 


\section{The interaction of the National Police with state authoroties and local self-government bodies in the area of the united forces operations}

Let's stop at the characterization of the etymological content of the concept of «interaction». This term is widely used in theory and in practice in various fields of knowledge, each of which gives it its definition. Thus, in the Great Explanatory Dictionary of Modern Ukrainian Language, the term «interaction» is interpreted as «cooperation, cooperation. Relationship between objects in action, as well as concerted action between someone or something» ${ }^{6}$.

In the broad sense, «interaction» is a joint action, that is, the interaction between the objects in action and the concerted action between them ${ }^{7}$; interaction serves as a form of communication of elements of the system by which they, by complementing each other, create the conditions for the successful functioning of the system as a whole; the state of interconnections between the elements of the system by which they interact with each other and the relevant field of activity ${ }^{8}$.

Based on the etymology of the word «interaction», we should note its similarity to the term "coordination», which in the reference literature is understood as the coordination, alignment, correlation between actions, objects, people, movements, etc. ${ }^{9}$. This was the root cause of lively discussions among scientists about the relationship between the concepts of «interaction» and «coordination».

Without going into the controversy over the relation between the concepts of «interaction» and «coordination», we think that the understanding of coordination proposed by V.M. Plishkin, according to which it is a management activity, aimed at harmonizing the functioning of elements of the system of law enforcement agencies in a mode that ensures the most effective achievement of the goals set before the system of goals, that is, coordination consists in the organization, first of all, by legal means, of interaction between elements of the system ${ }^{10}$.

\footnotetext{
${ }^{6}$ Великий тлумачний словник сучасної української мови / уклад. і голов. ред. В. Т. Бусел. Київ ; Ірпінь : Перун, 2009. 1736 с.

${ }^{7}$ Новий тлумачний словник української мови : у 4 т. Т. 1 / уклад.: В. Яременко, О. Сліпушко. Київ : Аконіт, 1998. 910 с.

${ }^{8}$ Плішкін В. М. Теорія управління органамй внутрішніх справ : підручник / за ред. Ю. Ф. Кравченка. Київ : Нац. акад. внутр. справ України, 1999. 702 с.

${ }^{9}$ Великий тлумачний словник сучасної української мови / уклад. і голов. ред. В. Т. Бусел. Київ ; Ірпінь : Перун, 2009. 1736 с.

${ }^{10}$ Плішкін В. М. Теорія управління органами внутрішніх справ : підручник / за ред. Ю. Ф. Кравченка. Київ : Нац. акад. внутр. справ України, 1999. 702 с.
} 
Thus, the main signs that characterize the theoretical concept of «interaction» of certain entities, include the following: 1) interaction requires the presence of at least two entities; 2) the subjects of the interaction are united by a single goal of accomplishing common tasks (unity and orientation of the functioning of the interacting entities); 3 ) interaction consists in the coordination of actions (implementation of measures) of the subjects by purpose, time, venue and program; 4) during the interaction, each of the interacting entities acts within the defined powers; 5) the interaction process is the object of normative legal regulation, the specifics of which are determined by the type of subjects of interaction; 6) in relation to coordination, the interaction between the entities is the object of management coordination activities.

The interaction of the National Police with state authorities and local self-government bodies are in accordance with the general provisions of the Law of Ukraine «On the National Police». Thus, Article 5 of the said Law stipulates that «in the course of its activity, the police shall interact with law enforcement and other public authorities, as well as local self-government bodies in accordance with the law and other normative legal acts» ${ }^{11}$.

The content of the interaction of the National Police is more broadly disclosed in p. 8 of the Regulation on the National Police, approved by the Cabinet of Ministers of Ukraine from 28.10.2015 № 877, according to which «the National Police, in the performance of its tasks, interacts with other state bodies, subsidiary bodies and services formed by the President of Ukraine, temporary advisory, advisory and other auxiliary bodies established by the Cabinet of Ministers of Ukraine, local self-government bodies, citizens' associations, public associations ILOs, trade unions and employers' organizations, relevant bodies of foreign countries and international organizations, as well as enterprises, institutions and organizations» 12 .

According to Art. 4 of the Law of Ukraine «On the Fight Against Terrorism», the entities that directly fighting against terrorism within their competence include: Ministry of Internal Affairs of Ukraine; Ministry of Defence Ukraine; central executive bodies that ensure the formation and implementation of state policy in the field of civil protection; the central

\footnotetext{
${ }^{11}$ Про Національну поліцію : Закон України від 02 липн. 2015 р. № 580 - VIII. URL: https://zakon.rada.gov.ua/laws/show/580-19 (дата звернення: 21.11.2019).

${ }^{12}$ Про затвердження Положення про Національну поліцію : Постанова Кабінету Міністрів України від 28 жовт. 2015 р. № 877. URL: http://zakon.rada.gov.ua/laws/show/ 877-2015 - п (дата звернення: 19.11.2018).
} 
executive body implementing state policy in the field of state border protection; the central body of the executive power, which implements the state policy in the sphere of execution of criminal penalties; Department of State Protection of Ukraine; central executive body implementing state tax policy, state policy in the field of state customs ${ }^{13}$.

Among the subjects directly engaged in the fight against terrorism, the National Guard of Ukraine plays a leading role in ensuring public security, which directly follows from the list of the main functions of the latter, including: 1) protection of the constitutional order of Ukraine, the integrity of its territory from attempts to change them by force; 2) protection of public order, ensuring protection of life, health, rights, freedoms and legitimate interests of citizens; 3) participation in the provision of public safety and public order during meetings, rallies, marches, demonstrations and other mass events that pose a danger to the life and health of citizens (Art. 2 of the Law of Ukraine «On the National Guard») ${ }^{14}$.

This stipulates the need to cover issues of interaction between the National Guard of Ukraine and the National Police regarding public security in the area of the united forces operations.

At the departmental level, by the order of the Ministry of Internal Affairs of Ukraine from 10.08.2016 № 773 defined the mechanism of organizing the interaction of the National Guard of Ukraine and the National Police of Ukraine in the sphere of ensuring (protection) of public (public) security and order ${ }^{15}$. In particular, according to the Order of organization of interaction between the National Guard of Ukraine and the National Police of Ukraine while ensuring (protection) of public (public) security and the order approved by the order of the Ministry of Internal Affairs of Ukraine №773, the interaction between these entities shall be carried out within the limits specified by the legislation, by: 1) joint patrolling of streets, squares, parks, stations, airports, seaports and river ports, other public places; 2) ensuring (protection) of public security and order during meetings, rallies, street campaigns, demonstrations, other mass and sports events, as well as during events in public places with the participation of people for whom the state is carried out protection;

\footnotetext{
${ }^{13}$ Про боротьбу 3 тероризмом : Закон України від 20 бер. 2003 р. № 638-IV. URL: https://zakon.rada.gov.ua/laws/show/638-15/ed20090611 (дата звернення: 23.11.2019).

14 Про Національну гвардію України : Закон України від 13 бер. 2014 р. № 876-VII. URL: https://zakon.rada.gov.ua/laws/show/876-18 (дата звернення: 12.10.2019).

15 Про затвердження Порядку організації взаємодії Національної гвардії України та Національної поліції України під час забезпечення (охорони) публічної (громадської) безпеки і порядку : Наказ МВС України від 10 серп. 2016 р. № 773. URL: http://zakon1.rada.gov.ua/ laws/show/z1223-16 (дата звернення: 28.11.2019).
} 
3) carrying out joint actions in order to stabilize the operational situation in case of its aggravation within the territory of one or more administrativeterritorial units.

It is important to note that this provision is effective only in peacetime, except during a state of emergency (p. 2, p. 1 of the order of organization of interaction between the National Guard of Ukraine and the National Police of Ukraine while ensuring (protection) of public (public) security and order). At the same time, despite the obvious necessity, the issues of interaction between the National Police and the National Guard of Ukraine on ensuring public security in the context of the anti-terrorist operation did not find their proper coverage within the framework of this legal act. Therefore, it is important to make appropriate additions to the Order of organization of interaction between the National Guard of Ukraine and the National Police of Ukraine while ensuring (protection) of public (public) security and the order, which should provide features of interaction between the National Police and the National Guard of Ukraine on ensuring public security not only in peacetime, but also in the context of the united forces operations.

The Law of Ukraine «On the Fight Against Terrorism» provides possibility of involvement in participation in the united forces operations. The Law of Ukraine «On Combating Terrorism» provides for the possibility of involving any central and local executive authorities, local self-government bodies, enterprises, institutions, organizations regardless of their subordination and ownership, their officials, and citizens with their consent (p. 5, 6, Art. 4). Interaction of state bodies, local self-government bodies, associations of citizens, organizations, their officials as reports on information they have become aware of, about terrorist activity or any other circumstances, information about which can contribute to the prevention, detection and termination of terrorist activity, as well as minimizing its consequences, in particular to the bodies of the National Police, is a mandatory requirement under Art. 9 of the Law of Ukraine «On the Fight Against Terrorism».

The relevant provisions of the Title Law correspond to the content of the normative acts that regulate the activity of the respective bodies. For example, Art. 38 of the Law of Ukraine «On Local Self-Government in Ukraine» to the authority to ensuring the law, order, protection of rights, freedoms and legitimate interests of citizens related "promoting activities of the bodies of the National Police, as well as the court, the prosecutor's office, justice, the security service, the National Anti-Corruption Bureau of 
Ukraine, the Advocacy and the State Criminal Enforcement Service of Ukraine» (p. 2 p. 1).

In turn, solution of the issue of the essence of the interaction of the National Police with other public security entities in the context of the united forces operations needs to cover not only the legal basis, but also the practice of implementing specific measures by the relevant entities.

Thus, thanks to the effective cooperation of the Ministry of Internal Affairs of Ukraine, the National Police, regional and city councils, representatives of business structures and the public, a Unified Analytical Service Center (UASC) was established in Donetsk region ${ }^{16}$.

Analytical Center created on the example of the Abu Dhabi security system and became the first unit in Ukraine based on smart technologies. Similar systems are in Singapore, London and now in Mariupol. Intelligent software designed specifically for the needs of the region's police forces, where fighting takes place and allows for the quickest response to events, prevention of crime and crime detection in the first hours after committing.

Components that work in a single UASC system: call center 102, intelligent video surveillance system, mobile application «Police 102», smart public transport stop in Mariupol. All of this is a part of a joint police and community project - «Safe Donetsk». The system works even where there is almost no connection, in remote locations and on the battle line. Thanks to modern equipment, IP-telephony, residents have the opportunity to notify law enforcement officers of the offense, which will be automatically fixed and the police will come to the aid immediately specially equipped and ready for any situations ${ }^{17}$.

In cooperation with local communities and the United Nations Development Program, intelligent video surveillance cameras have been installed in Mariupol, Pokrovsk, Velyka Novosilka, Slavyansk and frontline Novgorod, that work in crowds, junctions, in and out of cities. Camcorders are the only ones in the country able to identify the brand, model and color of a car, responding to loud sounds and flashes.

The Unified Analytical Service Center program has over 700 functions; more than 100 smart camcorders work; within 15 seconds the camera recognizes the danger and sends an alarm to the center; call handling and referral for police assistance takes 3-5 minutes; with the introduction of the UASC, the number of calls to the police has doubled.

\footnotetext{
${ }^{16}$ В Маріуполі запустили Єдиний аналітичний сервісний центр UASC. Everest.ua : вебсайт. URL: https://www.everest.ua/v-mariupoli-zapustyly-yedynyy-analitychnyy-servisnyytsentr-uasc (дата звернення 15.11.1019).

${ }^{17}$ Ibid.
} 
Having reviewed with the experience of the Donetsk police in the field of «reasonable» security, including for the release of the abducted person, the leadership of the National Police decided to use the Donetsk Police Unified Analytical Service Center as an example in implementing a security program throughout Ukraine.

In addition, with a view to timely identification of the facts of sending and receiving weapons and explosives, which are sent with the aim of destabilizing the socio-political situation and further deepening the conflict in Donetsk and Luhansk regions, special attention is paid to establishing a constant dialogue and interaction of the National Police with the management of regional offices of Ukrposhta, express delivery of Nova Poshta and other organizations that providing luggage services.

An important area of interaction between the National Police and other law enforcement agencies and volunteers is the search for missing, abducted citizens and captured people. For this purpose, systematically exchanges information with the Joint Center for Coordination of Search, release of unlawfully imprisoned people, hostages, and detection of missing people in the area of anti-terrorist operation that operated by the SSU. Interaction is also taking place with the Armed Forces Law Enforcement Service, the State Border Guard Service of Ukraine, territorial units of the forensic expertise of the Ministry of Health of Ukraine, the National Committee of the Red Cross of Ukraine, and volunteer organizations that keep records of the missing, captured and captured people. Thanks to the joint measures taken, including as a result of the Minsk Agreements, the number of unidentified missing people was reduced.

The research of the administrative and legal content of the interaction of the National Police with other state authorities and local self-government bodies in the area of the operation of the Joint Forces led to the conclusion that the interaction can have two directions: the first is the internal one, which is to coordinate activities with entities directly engaged in combating terrorism within a single state prevention system, responding and ending of terrorist acts and minimizing their consequences; the second is external, coordination of activities with other equal, independent bodies of state power, bodies of local self-government, enterprises, institutions and organizations regardless of subordination and form of ownership, as well as the public.

In our turn, we have found out that the existing administrative normative acts that regulating the interaction of the National Police with other state authorities (first of all, the entities directly engaged in the fight against terrorism) in the field of public security, do not meet the current 
challenges of the fight against terrorism. Instead, the organizational and legal aspects of the interaction of the National Police with the entities that engaged in direct counter-terrorism that were developed in the context of the anti-terrorist operation and the united forces operations in the eastern regions of Ukraine during 2014-2019, should become a key source for improvement of the legal framework in the sphere of interaction of the described bodies.

\section{Interaction of the National Police of Ukraine with the public in the area of the united forces operations}

Issues of interaction between the National Police and the public in the performance of its public security and law enforcement responsibilities in the area of the united forces operation are defined by the current legislation of Ukraine as key and that, which determine the success of the police bodies and units.

In Art. 11 of the Law of Ukraine «On National Police», «interaction of police with the population on the basis of partnership» has been called one of the principles of the National Police. The content of this principle is as follows: a) police activities are carried out in close cooperation and interaction with the public, territorial communities and public associations on the basis of partnership and aimed at meeting their needs; b) in order to determine the causes and / or conditions of committing offenses of planning of service activities of police bodies and units is carried out taking into account the specificity of the region and the problems of territorial communities; c) the level of public trust in the police is the main criterion for evaluating the effectiveness of the activities of police bodies and units ${ }^{18}$.

The Law of Ukraine «On the National Police» also stipulates that the police interact with the public through the preparation and implementation of joint projects, programs and activities to meet the needs of the population and improve the effectiveness of the police in carrying out their tasks. In particular, the police support legal education programs, promote legal knowledge in educational institutions, the media and in publishing activities (Art. 89).

Cooperation between the police and the public is aimed at identifying and eliminating problems related to policing and promoting the use of modern methods to increase the efficiency and effectiveness of such

18 Про Національну поліцію : Закон України від 02 липн. 2015 р. № 580 - VIII. URL: https://zakon.rada.gov.ua/laws/show/580-19 (дата звернення: 21.11.2019). 
activities. In particular, control over police activity can be carried out in the form of involving members of the public in joint consideration of complaints about the actions or omissions of police officers and verification of information on the proper performance of their duties in accordance with the laws and other legal acts of Ukraine (Art. 89, 90 of the Law of Ukraine «On National Police») ${ }^{19}$.

In order to determine the causes and conditions of committing offenses, planning of service activities of police bodies and units is tailored to the specificity of the region and problems of local communities, and the level of public trust in the police is the main criterion for evaluating the effectiveness of police activity.

Except to the above, the heads of territorial bodies and police units should hold open meetings with representatives of local governments at the levels of regions, districts, cities and villages at least once every two months in order to establish cooperation between the police and local authorities and the population. Such meetings discuss activities of the police, identify current problems and select the most effective ways to solve them.

In order to increase the authority and confidence of the population in the police, the bodies and units of the National Police of Ukraine should systematically inform the public about the state of law and order, that used to prevent offenses.

An important area of interaction between the police and the population the legislation defines the preparation and implementation of joint orders, programs and measures to meet the needs of the population and to improve the effectiveness of police implementation of their assigned tasks. In addition, the police have an obligation to support legal education programs, to promote legal knowledge in educational institutions and the media.

These provisions of the current legislation on the necessity of interaction between the national police of Ukraine and the public can be summarized as follows:

1) the police must carry out their duties taking into account the needs of the local community and individual groups of its population;

2) the management of territorial units of the police should hold meetings with representatives of local self-government bodies, at which the activities of the police should be discussed, the current problems of public safety of citizens and ways of their solution should be solved;

19 Про Національну поліцію : Закон України від 02 липн. 2015 р. № 580 - VIII. URL: https://zakon.rada.gov.ua/laws/show/580-19 (дата звернення: 21.11.2019). 
3) units of the National Police should inform the public about the state of law and order in the subordinate territory;

4) the police and members of the public can develop joint projects, programs and activities to meet the needs of the population, as well as improve the effectiveness of the police in carrying out their tasks;

5) the police should be involved in legal education of the population.

The analysis of information sources of the Main Directorates of the National Police in Lugansk and Donetsk regions shows that work is being done to establish interaction with the population in the following areas:

1) Work of public organizations of legal direction. A striking example of interaction between the National Police and the public is the creation of a public organization "Youth League of Future Police», involving young people aged 14 to 35 who has an interest and desire to contribute to the activities of the National Police, seeks to study military special and physical training, historical traditions of Ukraine ${ }^{20}$. The main purpose of the Future Police League is to carry out activities aimed at realizing creative abilities, improving the moral, patriotic education of young people, raising their awareness, aimed at preventing the commission of offenses, neglect and homelessness, providing them with opportunities for self-realization, self-realization lifestyle.

The positive achievements of the Future Police League are the development of skills needed to protect rights and freedoms; education of youth in the spirit of patriotism and observance of generally accepted norms and rules of behavior; involvement of young people in practical human rights work; assistance to the territorial bodies of the Main Directorate of the National Police in Donetsk region in the work on prevention of neglect and offenses among teenagers and youth.

In addition, the United Nations Development Program proposed a joint project with the League of Future Police «League of Action», which concerned mediation in schools. Public organisations of Mariupol provided a methodology for training mediators. Thus, together with the police of Donetsk region, the first thirty mediators were trained. In addition, ten UNICEF-supported schools in the city have school-based liaison services. The latter consist of students who will independently reconcile peer conflicts through mediation ${ }^{21}$.

\footnotetext{
${ }^{20}$ Програма громадської організації «Молодіжна ліга майбутніх поліцейських». Liga-police. ucoz.net : веб-сайт. URL: https://liga police.ucoz.net/index/programa_gromadskoji_organizaciji_ 39_39_molodizhna_liga_majbutnikh_policejskikh_39_39/0-4 (дата звернення: 23.11.2019).

${ }^{21}$ Ibid.
} 
2) Another example of police-public interaction is the Swallow project, initiated by the public organization «Trust Fund» with the assistance of the United Nations Development Program. As part of this project, 18 volunteers from the Mariupol Police Department and General have been trained in sign language and fingerprinting.

On August 3, 2018, for the first time in Ukraine, the Head of the Police of Donetsk Region, Mykola Semenyshyn, handed over certificates to operative commissioners, investigators, district police officers and inspectors of juvenile prevention with knowledge of sign language and dactyl. Police officers successfully trained and in a new format provide services to hearing impaired citizens ${ }^{22}$.

3) Particular attention should be paid to joint projects of the Donetsk police and the public, such as: the Safe House Innovation Project; creation of a safe workplace for police officers serving at posts in Donetsk region; the School Police Officer project; pilot project «Polina»; Neighborhood Watch project ${ }^{23}$.

On November 3, 2018, in Donetsk region, in the frontline region, police implemented the project «School Police Officer», with the aim of safe stay of children in the educational institutions of Mariupol, Kramatorsk and Slavyansk. The aim of the project is to solve the problem of juvenile and child crime in Mariupol educational institutions by combining the efforts of the police who provide crime prevention and the schools responsible for teaching children ${ }^{24}$.

The Safe House project is part of a unified strategy for the development of the Ministry of Internal Affairs and unites the efforts of law enforcement, local authorities, self-organizing committees and associations of co-owners of apartment buildings for the safety of citizens and involves a tripartite cooperation: «Police - Community - Government». This program helps residents of multi-storey buildings to determine their own level of safety ${ }^{25}$.

\footnotetext{
${ }^{22}$ Проект «Ластівка»: 18 поліцейських Донеччини отримали сертифікати сурдоперекладачів. Mariupol-police.dn.uа : веб-сайт. URL: http://mariupol-police.dn.ua/news/view/3571 (дата звернення: 23.11.2019).

${ }^{23}$ Вітвіцький С. С. Консолідація діяльності органів Національної поліції та потенціалу громадськості як стратегічний напрямок забезпечення публічного порядку в умовах операції Об'єднаних сил. Забезпечення правопорядку на території проведення операції Об'єднаних сил : матеріали Всеукр. наук.-практ. семінару, 12 жовт. 2018 р. Маріуполь : МДУ, 2018. С. 179-188.

${ }^{24}$ На Донеччині поліцейські впровадили проект «Шкільний офіцер поліції». Поліція Донеччини: веб-сайт. URL: http://police.dn.ua/news/view/na-donechchini-politsejski-vprovadiliproekt-shkilnij-ofitser-politsii (дата звернення: 23.11.2019).

${ }^{25}$ В центрі Краматорська 3'явився «Безпечний будинок». Полічія Донеччини : веб-сайт. URL: http://police.dn.ua/news/view/v-tsentri-kramatorska-zyavivsya-bezpechnij-budinok (дата звернення 15.11.1019).
} 
On February 6, 2018, the mobile group «Polina» started operating in the Left Bank District of Mariupol in order to respond to the facts of domestic violence. In the future, the work of the group began to operate throughout the Donetsk region. Police respond to calls for combating domestic violence, draw up reports of administrative offenses for committing domestic violence, and open criminal proceedings when establishing the facts of personal injury. In addition, police inspect persons who are on and off the record for committing domestic violence: communicating with victims and neighbors about re-committing domestic violence. For systematic preventive work with the aggressors, the police plan to create a «map of the offender» with information on social status, place of work, number of children, etc.

Now, for police officers are conducting trainings on countering domestic violence, which have been implemented with the assistance of public organizations «Council of Women of Donetsk Region» and «Mariupol Youth Union».

Over the first half of 2019, more than 23,000 people have contacted «La Strada - Ukraine» national hotlines for domestic violence ${ }^{26}$.

Since 2017, the Neighborhood Watch Project has been launched thanks to the initiative of residents in cooperation with patrol officers, local authorities and international partners. The main task of the neighborhood watch approach is to develop a bona fide neighborhood and a shared responsibility for the safety of one's home and yard. The project provides for: prevention of crime by increasing the vigilance of neighbors and their awareness of the area; improving the safety of the community; a sense of security of your own space; improving communication between the community, the police and other public authorities and local selfgovernment through active communication; the ability to respond properly to security threats by obtaining credible information from police representatives and having a clear algorithm for responding to such threats; improvement of the yard $^{27}$.

4) In the area of the united forces operations, police cooperation with public formations on public order and state border deserves special attention. In accordance with the provisions of the Constitution of Ukraine,

26 Поліція поширює проєкт протидії домашньому насильству «Поліна» на всю Україну - Клименко. Radiosvoboda.org : веб-сайт. URL: https:/www.radiosvoboda.org/a/ news-policija-poshyriye-proekt-protydii-domashniomu-nasylstvu-na-vsiu-ukrainu-

klymenko/30204166.html (дата звернення: 23.11.2019).

27 Сусідська варта: безпека-добробут-порядок. На Галичині і в Донбасі. Prostir.ua : веб-сайт. URL: https://www.prostir.ua/?news=susidska-varta-bezpeka-dobrobut-poryadok-nahalychyni-i-v-donbasi (дата звернення: 23.11.2019). 
citizens of Ukraine have the right to create in the statutory law of Ukraine «On citizens' participation in the protection of public order and the state border» - public associations, to participate in the protection of public order and the state border, to assist local authorities, law enforcement agencies, the State Border Service of Ukraine and executive authorities, as well as officials in the prevention and termination of administrative offenses and crimes, protection of life and crime, citizens, interests of society and the state from unlawful encroachments, as well as in the rescue of people and property during natural disasters and other extraordinary circumstances ${ }^{28}$.

The content of the interaction of the National Police with public formations in the protection of public order in the field of public security is easy to evaluate based on the content of their main tasks (Article 9 of the Law of Ukraine «On Participation of Citizens in the Protection of Public Order and State Border»), namely: assisting the National Police in the maintenance of public order and public safety, the prevention of administrative misconduct and crimes; informing the bodies of the National Police about the crimes committed or in preparation, the places of concentration of criminal groups; assistance to the bodies of the National Police in the detection and disclosure of crimes, the search of people who have committed them, the protection of the interests of the state, enterprises, institutions, organizations, citizens from criminal encroachments; participation in road safety and combating child neglect and juvenile delinquency.

In Donetsk Oblast, in accordance with the requirements of the Law «On Citizens' Participation in the Protection of Public Order and the State Border», 33 public formations were created and registered (12 of them in 2018). The total number of members of public formations is 390 (of which 189 were recruited in 2018). During 2017, the Donetsk police together with public formations carried out 857 public order actions, 316 joint preventive raids. Within the framework of the support program, the regional state administration has allocated funds for the promotion of public formations. During the events with the participation of members of public formations, 1137 people were detained for committing offenses, 52 of them - criminal and 1085 - administrative offenses ${ }^{29}$.

\footnotetext{
${ }^{28}$ Про участь громадян в охороні громадського порядку і державного кордону : Закон України від 22 черв. 2000 р. № 1835-III. URL: http://zakon.rada.gov.ua/laws/show/1835-14 (дата звернення: 13.02.2018).

${ }^{29}$ Війна зобов'язала поліцейських на Донбасі стати краще. Communiti policing : вебсайт. URL: http://cop.org.ua/ua/ukrainskyi-dosvid/donetska-oblast/general-mikola-semenishinvijna-zobov-yazala-politsejskikh-na-donbasi-stavati-krashchimi_(дата звернення 15.11.1019).
} 
Members of the public formations, together with the police, that patrol streets and participate in preventive raids, in particular to counteract the spontaneous trade and sale of surrogate alcohol, traffic safety.

5) The implementation of the "Thin Blue Line» social project is an example of the interaction and support that residents express to police officers, and the blue ribbon in private and networked institutions is a sign that they trust the police. In Mariupol, several businesses have already joined this project and each has a corresponding symbol of engagement - blue ribbon. This project was also joined in Konstantinovka and Slavyansk ${ }^{30}$.

In the light of these examples, the units of the National Police of Ukraine, which operate in the area of the united forces operations, use a very large number of forms of interaction with civil society institutions. However, these activities can be significantly optimized and improved, taking into account the international experience of such policing.

Summarizing the issues of interaction of the National Police with the public in the area of the united forces operations, it can be concluded that the potential of the public and the police is the basis for improving the effectiveness of all subjects in achieving the goals of maintaining public safety in society, and coordination will provide police relations and public formation of a sustainable, purposeful nature, will ensure the optimal distribution of law enforcement functions, unity of strategic and tact their actions.

In turn, the main forms of interaction between the National Police and the public, including in the area of the united forces operations, can be attributed to: involvement of the public in human rights work; citizen participation in maintaining public safety and order; informing the police about crimes and people who involved in committing them (preparation); organizational assistance of an informative nature regarding the search of missing persons; participation of the public in the training of police officers in the formation of narrow-sector knowledge to meet the needs of the population; providing logistical support to improve police activities; implementation of programs of legal and patriotic education of the population; capacity building for National Police bodies through the implementation of joint projects for youth seeking legal, military-special and physical training, etc.

Based on the above characteristics, the interaction of the National Police with other public security entities during the united forces

30 До ініціативи «Тонка синя лінія» приєднався магазин побутової техніки. Mariupolpolice.dn.иа : веб-сайт. URL: http://mariupol-police.dn.ua/news/view/4939 (дата звернення: 23.11.2019). 
operations should be understood as based on legislative and regulatory acts agreed upon by purpose, time, place of activity between the entities that directly carry out combat terrorism arising from the organizational activities of the specially created coordination bodies, and other equally independent state bodies, local self-government bodies and the public for the purpose of their concerted functioning in protecting the rights, freedoms and ensuring the safety of citizens, and the cessation of acts of terrorism and other offenses by the most expedient combination of the forms and methods peculiar to those subjects.

Consequently, the fulfillment of public security tasks by the police, in particular in the context of the united forces operations, depends to a large extent on its interaction with counter-terrorism bodies, other public authorities, local self-government bodies and civil society institutions. In the course of such interaction, there is a constant exchange of information on problematic issues and elimination of factors that destabilize the situation in the region, coordinate actions with members of the public, media coordinators, local people who involved in maintaining public order, public and private organizations, that provide security services, delivery, etc. to effectively control the operational environment and implement joint actions in the event of a real terrorist threat.

\section{CONCLUSIONS}

The interaction of the National Police with other public security entities during the united forces operations is necessary to understand the legislation and regulations based on the goals, time, place of activity between the entities, that directly carry out combat terrorism arising from the organizational activities of the specially created coordination bodies, and other equally independent state bodies, local self-government bodies and the public for the purpose of their concerted functioning in protecting the rights, freedoms and ensuring the safety of citizens, and the cessation of acts of terrorism and other offenses by the most expedient combination of the forms and methods peculiar to those subjects.

The interaction of the National Police with the authorities, local selfgovernment and the public in the area of the united forces operations depends directly on: from developing plans of interaction at the state and local levels; mutual information on socio-economic, military-political, strategic and operational situation; defining the scope and sequence of joint actions in the performance of joint and individual service tasks; coordination of the procedure of joint actions for making urgent decisions of subordination and interaction of units in the process of performing joint 
tasks, solving issues of logistics; co-ordination of joint actions (joint determination of placements, staffing and order of joint activities; assessing the nature of the threat, status and capabilities of available forces and means; determining the leader of joint events in agreement with the leaders of the interacting parties; determining the need to involve other additional forces and means.

Built at the Main Police Department in the Donetsk region Built at SUNP in the Donetsk region, the unique Unified Analytical Service Center (UASC) in Mariupol allowed to bring the level of citizens' safety to a new level by focusing on the introduction of the latest technologies, building on the best international experience of countries such as the United Kingdom, United Arab Emirates Emirates and Italy. Thanks to the UASC, in the context of the united forces operations, the police work in the following areas: improving the security of citizens; modernization and development of technologies of the automated security management infrastructure of the designated area; use of advanced technologies for effective city management; active involvement of the police, local authorities, the business environment and the public.

Particular attention should be paid to such joint projects by the Donetsk police and the public as: the Safe House Innovation Project; creation of a safe workplace for police officers serving at posts in Donetsk region; «the School Police Officer» project; pilot project «Polina»; «the Thin Blue Line» project; Neighborhood Watch project and cooperation with the public organization «Future League of Police Officers».

\section{SUMMARY}

The article is devoted to the study of the main provisions of the interaction of the National Police with state authorities, local selfgovernment and the public in the area of the united forces operations. Theoretical approaches to the definition and correlation of the concepts of «interaction» and «coordination» are investigated. The concept of interaction of the National Police with other subjects in the field of public security and order during the united forces operations is formulated. The main directions of cooperation of the National Police bodies with other state authorities and local self-government bodies in the area of the united forces operations are determined. The basic tasks and functions of these entities in relation to the interaction in the area of the united forces operations are disclosed. The activity of unique Unified Analytical Service Center (UASC), which was created on the basis of the Main Police Department in Donetsk region, is analyzed. The work of public 
organizations with which the National Police of Ukraine interacts is characterized by: "Youth League of Future Police Officers»; «the Swallow» project; «Safe House» project; «the Polina» Project; «the School Police Officer» project; «the Neighborhood Watch» project; social project «Thin Blue Line». The content of the interaction of the National Police with public formations in the field of public order concerning the provision of public security in the area of the united forces operations is disclosed.

\section{REFERENCES}

1. Про боротьбу з тероризмом : Закон України від 20 бер. 2003 р. № 638-IV. URL: https://zakon.rada.gov.ua/laws/show/638-15/ed20090611 (дата звернення: 23.11.2019).

2. Про місцеве самоврядування в Україні : Закон України від 21 трав. 1997 р. № 280/97-BP. URL: https://zakon.rada.gov.ua/laws/ show/280/97-вр (дата звернення: 09.11.2019).

3. Про Національну гвардію України : Закон України від 13 бер. 2014 p. № 876-VII. URL: https://zakon.rada.gov.ua/laws/show/876-18 (дата звернення: 12.10.2019).

4. Про Національну поліцію : Закон України від 02 липн. 2015 p. № 580 - VIII. URL: https://zakon.rada.gov.ua/laws/show/580-19 (дата звернення: 21.11.2019).

5. Про участь громадян в охороні громадського порядку і державного кордону : Закон України від 22 черв. 2000 р. № 1835-III. URL: http://zakon.rada.gov.ua/laws/show/1835-14 (дата звернення: 13.02.2018).

6. Про рішення Ради національної безпеки і оборони України від 13 квітня 2014 року «Про невідкладні заходи щодо подолання терористичної загрози і збереження територіальної цілісності України» : Указ Президента України від 14 квіт. 2014 р. № 405/204. URL: https://zakon.rada.gov.ua/laws/show/405/2014 (дата звернення: 20.11.2019).

7. Про рішення Ради національної безпеки і оборони України від 30 квітня 2018 року «Про широкомасштабну антитерористичну операцію в Донецькій та Луганській областях» : Указ Президента України від 30 квіт. 2018 р. № 116/2018. URL: https://zakon5.rada.gov.ua/ laws/show/116/2018 (дата звернення: 21.11.2019).

8. Про затвердження Положення про Національну поліцію : Постанова Кабінету Міністрів України від 28 жовт. 2015 р. № 877. URL: http://zakon.rada.gov.ua/laws/show/877-2015 - п (дата звернення: 19.11.2018). 
9. Про затвердження Порядку організації взаємодії Національної гвардії України та Національної поліції України під час забезпечення (охорони) публічної (громадської) безпеки і порядку : Наказ МВС України від 10 серп. 2016 р. № 773. URL: http://zakon1.rada.gov.ua/ laws/show/z1223-16 (дата звернення: 28.11.2019).

10.В центрі Краматорська з'явився «Безпечний будинок». Полічуія Донеччини : веб-сайт. URL: http://police.dn.ua/news/view/v-tsentrikramatorska-zyavivsya-bezpechnij-budinok (дата звернення 15.11.1019).

11. Великий тлумачний словник сучасної української мови / уклад. і голов. ред. В. Т. Бусел. Київ ; Ірпінь : Перун, 2009. 1736 с.

12. Вітвіцький С. С. Консолідація діяльності органів Національної поліції та потенціалу громадськості як стратегічний напрямок забезпечення публічного порядку в умовах операції Об'єднаних сил. Забезпечення правопорядку на території проведення операції Об'єднаних сил : матеріали Всеукр. наук.-практ. семінару, 12 жовт. 2018 р. Маріуполь : МДУ, 2018. С. 179-188.

13.Війна зобов'язала поліцейських на Донбасі стати краще. Communiti policing : веб-сайт. URL: http://cop.org.ua/ua/ukrainskyidosvid/donetska-oblast/general-mikola-semenishin-vijna-zobov-yazalapolitsejskikh-na-donbasi-stavati-krashchimi (дата звернення 15.11.1019).

14.В Маріуполі запустили Єдиний аналітичний сервісний центр UASC. Everest.uа : веб-сайт. URL: https://www.everest.ua/v-mariupolizapustyly-yedynyy-analitychnyy-servisnyy-tsentr-uasc (дата звернення 15.11.1019).

15.Новий тлумачний словник української мови : у 4 т. Т. 1 / уклад.: В. Яременко, О. Сліпушко. Київ : Аконіт, 1998. 910 с.

16.Плішкін В. М. Теорія управління органами внутрішніх справ : підручник / за ред. Ю. Ф. Кравченка. Київ : Нац. акад. внутр. справ України, 1999. 702 с.

17.Програма громадської організації «Молодіжна ліга майбутніх поліцейських». Liga-police. ucoz.net : веб-сайт. URL: https://liga-police.ucoz.net/index/programa_gromadskoji_organizaciji_39_ 39_molodizhna_liga_majbutnikh_policejskikh_39_39/0-4 (дата звернення: 23.11.2019).

18. Проект «Ластівка»: 18 поліцейських Донеччини отримали сертифікати сурдоперекладачів. Mariupol-police.dn.ua : веб-сайт. URL: http://mariupol-police.dn.ua/news/view/3571 (дата звернення: 23.11.2019).

19.Поліція поширює проєкт протидії домашньому насильству «Поліна» на всю Україну - Клименко. Radiosvoboda.org : веб-сайт. URL: https://www.radiosvoboda.org/a/news-policija-poshyriye-proekt- 
protydii-domashniomu-nasylstvu-na-vsiu-ukrainu-klymenko/30204166. html (дата звернення: 23.11.2019).

20.Сусідська варта: безпека-добробут-порядок. На Галичині і в Донбасі. Prostir.uа : веб-сайт. URL: https://www.prostir.ua/?news= susidska-varta-bezpeka-dobrobut-poryadok-na-halychyni-i-v-donbasi (дата звернення: 23.11.2019).

21. До ініціативи «Тонка синя лінія» приєднався магазин побутової техніки. Mariupol-police.dn.ua : веб-сайт. URL: http://mariupol-police. dn.ua/news/view/4939 (дата звернення: 23.11.2019).

22.На Донеччині поліцейські впровадили проект «Шкільний офіцер поліції». Полічія Донеччини : веб-сайт. URL: http://police.dn.ua/ news/view/na-donechchini-politsejski-vprovadili-proekt-shkilnij-ofitserpolitsii (дата звернення: 23.11.2019).

\section{Information about the author:} Abroskin V. V., Doctor of Law, Rector of Odesa State University of Internal Affairs 1, Uspenska str., Odessa, 65000, Ukraine 


\section{IMPROVEMENT OF ADMINISTRATIVE AND LEGAL BASIS OF INSTITUTION OF JUSTICE OF UKRAINE}

\section{Predmestnikov O. H.}

\section{INTRODUCTION}

The system of justice is an indispensable component of the state apparatus of each state responsible for formulating and implementing its legal policy, asserting the rule of law, ensuring proper functioning of jurisdictional and related entities. Despite the common purpose of its activities the status, composition, competence and organization of the activities of the justice authorities in different countries differ significantly, which, in the first place, is determined by the peculiarities of their legal system, constitutional system, practice and state of construction and social development.

The leading role of the justice bodies of Ukraine in the implementation of state legal policies, improvements to national legislation, and providing the state registration, enforcement of court decisions and enforcement criminal penalties determine the importance of lawful and effective functioning of justice bodies. In this regard, the recent tendency to simplify the system of justice bodies and decentralize their activities, to ensure that they are prioritized and to exercise the citizens' rights is positive.

At the same time, there is still no unified concept of complex development of the status of justice bodies of Ukraine, and the current administrative and legal regulation of their status reveals some inconsistency and fragmentation, their competence is not fully consistent with the structural organization. The reasons for reforming the system of justice include the lack of productivity of their activities, cases of duplication of powers, formalism in the performance of certain tasks, irrational structure, unreasonably large administrative apparatus, shortage of skilled workers, manifestations of corruption and ineffectiveness.

\section{The experience of foreign countries in the organization of the activities of the justice authorities and opportunities for its implementation in Ukraine}

Today, within the framework of modern processes of European integration of Ukraine, democratization, humanization and decentralization of public administration, the system of justice organs of Ukraine is 
undergoing major reorganization changes, which makes the introduction of a positive foreign experience in organizing the activity of justice organs quite important.

Note that some aspects of the organization and operation of justice in other countries have previously been considered by such scientists as R.V. Budetskyy, A.Yu. Guliagin, I.I. Mykultsya, I.Yu. Onopchuk, V.O. Spasenko, A.F. Shestakov and others. At the same time, their scientific works are mainly devoted to the specific issues of organizing the activity of the bodies of justice only in certain foreign countries without their comprehensive comparison with each other, while not comprehensively characterizing the general essential features and differences of the current legal status of the bodies of justice in different countries. Research works of R.V. Budetskyy and I.I. Mykultsya in general are reduced only to citing the structure and basic powers of the Ministry of Justice units in the respective countries without thorough analysis. It is necessary to point out on the use by I.I. Mycultsya of outdated data on the UK justice system (governed not by «the Lord Chancellor's Department, the Home Office, the Attorney-General's and the Solicitor General's Department» ${ }^{1}$ since 2007, but by the relevant Justice Department). In view of this, in the context of improving the status of the justice bodies of Ukraine, the issues of foreign experience of organizing the activity of the justice bodies are also relevant.

First of all, let's note that the main factors that mainly depend on the organization of justice authorities in modern countries are as follows. First, it is political regime (democratic/undemocratic) and government (unitary/federal), on which centralization or decentralized administration in the field of justice, which is carried out only within a single hierarchy of the Ministry of Justice or as the Ministry of Justice and its bodies, as well as by municipal authorities and public institutions. Secondly, it is the degree and nature of the distribution of state power that determines segregation of public administration bodies from the independent/separate bodies of justice, prosecutors, etc. And third, it is succession and legal traditions, which preserves established features and pre-emulation of the existing model of organization of justice (eg, former colonies and dependent territories from the metropolis). It should be emphasized that the use of foreign experience in organizing the activity of justice bodies in Ukraine should also take into account the above and other objective factors.

\footnotetext{
${ }^{1}$ Микульця I. І. Адміністративно-правовий статус органів юстиції України: дис. ... канд. юрид. наук: 12.00.07. Харків, 2014. С. 159-160.
} 
The legal bases for the organization and operation of justice authorities in different countries are usually drawn up by relevant governmental acts and/or heads of state, as well as departmental acts of the Ministry of Justice to regulate their activities and the activities of subordinate bodies. One of the few examples of legislative regulation of the status of the bodies of justice is the Law of the Republic of Kazakhstan dated 18.03.2002 No. 304- $\mathrm{II}^{2}$, which reflects the systematic nature of the bodies of justice, fixing their common tasks, principles of activity, powers, rights and bases of status.

However, in different countries according to the peculiarities of their legal system the degree and content of the regulation of the organization and activity of bodies of Justice differs - if the Resolution of the Government of Moldova dated 03.10.2012 No. $736^{3}$ provides tasks, overall competence and leadership status (which is illustrative - not only Minister's, but also his deputies) of the Ministry of Justice of Moldova, then the Government Decree of France of 09.07.2008, No. 2008-689 outlines the structure in general terms of the Ministry of Justice of France and the main activities of its departments.

The structure of justice bodies in foreign countries is often fixed separately from their competences (for example, the powers of the Main Department of Justice of Minsk regional executive committee are defined by the decision of the regional executive committee from 09.03.2015 No. $199^{4}$, and its structure - by the order of the chairman of the regional executive committee of 25.04.2013, No. $90^{5}$ ). As on us, this approach can adversely affect rationality, unity and coherence of the functional and organizational bases of the activity of justice bodies.

In this regard, the most comprehensive is definitely a complex legislative regulation of organization of activity (status, guarantees, tasks, competences structure, status of leadership, foundations of relations, etc.)

\footnotetext{
${ }^{2}$ Об органах юстиции: закон Республики Казахстан от 18.03.2002 № 304-II. Ведомости Парламента Республики Казахстан. 2002. № 6. Ст. 67.

${ }^{3}$ Об организации и функционировании Министерства юстиции: постановление Правительства Республики Молдова от 03.10.2012 № 736. Monitorul Oficial. 2012. № 212-215. Ст. 799.

${ }^{4}$ Положение о главном управлении юстиции Минского областного исполнительного комитета: решение Минского областного исполнительного комитета от 09.03.2015 № 199/Минский областной исполнительный комітет. URL: http://minobljust.gov.by/ru/ polojenie (дата звернення: 17.12.2016).

5 Структура главного управления юстиции Минского областного исполнительного комитета: распоряжение председателя Минского областного исполнительного комитета от 25.04.2013 № 90p/Минский областной исполнительный комітет. URL: http://minobljust. gov.by/dadvfiles /000127_682722_struktura_gyu.doc (дата звернення: 17.12.2016).
} 
of the bodies of justice that corresponds to their leading role in the state and provides the necessary stability, validity, completeness and consistency of the legal bases of functioning justice agencies.

It should be noted as a positive reference by the Law of Kazakhstan of 18.03.2002 No. 304-II ${ }^{6}$ to the principles of activity of the bodies of justice not only legality, and respect for citizens' rights, publicity and engagement, but also independence from activities of public associations and the unity of the justice system.

Liquidation of district level justice bodies, optimization of competence and the structures of the justice system of Ukraine led to the establishment of a limit number of employees of the Ministry of Justice of Ukraine apparatus and its staff territorial bodies at the level of 1097 and 16675 persons. In turn, the Ministry of Justice of Germany has about 760 employees $^{7}$, about 300 employees $^{8}$ work in the Austrian Ministry of Justice. Accordingly, possible and expedient appears to be the further reducing the number of employees of the Ukrainian justice authorities by depriving them of their inappropriate and irrelevant powers, eliminating duplicate and inefficient units, more efficient staff redeployment, and more.

In foreign countries there are different approaches to defining composition and tasks of systems of justice bodies (governing bodies in the field of justice). For the post-Soviet countries the traditional presence of the Ministry of Justice and its territorial bodies is quite traditional with different degree of separation from courts, prosecutors, bodies of the penitentiary system which are either independent of the Ministry of Justice, or subordinated to it.

In particular in the Republic of Belarus the system of justice bodies respectively to the Resolution of the Council of Ministers of Belarus of October 31, 2001 No. $1605^{9}$ is exactly Ministry of Justice, main departments of justice of regional executive committees and Minsk city executive committees, registries (departments of record of acts of a civil status) of regional executive committees and local administrations

${ }^{6}$ Об органах юстиции: закон Республики Казахстан от 18.03.2002 № 304-II. Ведомости Парламента Республики Казахстан. 2002. № 6. Ст. 67.

7 Aufgaben und Organisation Ministerium/Das Bundesministerium der Justiz und für Verbraucherschutz. URL: http://www.bmjv.de/DE/Ministerium/AufgabenOrganisation/Aufgaben Organisation_node.html (дата звернення: 17.12.2016).

8 Organisation/Die Österreichische Justiz. URL: https://www.justiz.gv.at/web2013/home /ministerium/organisation 8ab4a8a422985de30122a91a6504629f.de.html (дата звернення: 18.12.2016).

${ }^{9}$ Об утверждении Положения о Министерстве юстиции Республики Беларусь: постановление Совета Министров Республики Беларусь от 31.10.2001 № 1605. Национальный реестр правовых актов Республики Беларусь.2001. № 107. Ст. 5/9385. 
of districts in cities, Registry (Palaces) of civil ceremonies of city executive committees, as well as subordinate state organizations (although the latter are not subjects of authorities and therefore should not be considered as bodies of Justice). At the same time, we should note the falseness of referring by I.I. Mycultsya ${ }^{10}$ the district courts and lawyers to the structure of the main justice department of the Minsk City Executive Committee of Belarus.

Therefore, to the peculiarities of the organization of the justice system of Belarus is referred, first of all, the organizational formation of the main departments of justice in the composition of regional executive committees, that results in their double subordination to the respective Regional Executive Committee and at the same time to the Ministry of Justice of the Republic of Belarus (item 1 of Regulation approved by the Decision of the Minsk Regional Executive Committee of 09.03.2015 No. $199^{11}$ ). A similar approach to organizing the activities of territorial justice bodies significantly complicates the management of their activities and urgently requires clear delimitation of organizational and administrative powers of the Ministry of Justice of Belarus and regional executive committees on the main departments of justice. In doing so, the effective functioning of the territorial bodies of justice depends not only on their constructive relations and interaction with local authorities, but also from direct and unconditional submission to the Ministry of Justice of its territorial bodies. Therefore, we do not see an urgent need for direct organizational subordination of the main departments of justice to regional executive committees (or similar to local authorities in Ukraine), which can be completely replaced by the control and accountability of the territorial bodies of justice.

Another specific feature of the organization of the justice system in Belarus is segregation and separation of civil records departments (registries) from territorial bodies of justice acting within the district executive committees with double subordination of the district executive committee and the corresponding department of justice.

This approach to the organization of the activities of the departments of the record of acts of civil status (registries) allows to actually delegate civil registration functions to local authorities (in this case district executive

${ }^{10}$ Микульця I. І. Адміністративно-правовий статус органів юстиції України: дис. ... канд. юрид. наук: 12.00.07. Харків, 2014. С. 161-162.

${ }^{11}$ Положение о главном управлении юстиции Минского областного исполнительного комитета: решение Минского областного испонительного комитета от 09.03.2015 № 199/Минский областной исполнительный комітет. URL: http://minobljust.gov.by/ru/ polojenie (дата звернення: 17.12.2016). 
committees, city executive committees and local district administrations in cities). This, in turn, promotes their responsibility and roles in managing public affairs and unloading of the main departments of justice, while keeping them sufficient organizational and supervisory powers in this area. The above said much corresponds to the modern tendencies of decentralization and demonopolization of activity of the Ukrainian justice authorities, one of the aspects of which is the delegation of powers from state registration to local authorities.

Granting the status of independent bodies of executive power to the bodies of the coercive enforcement of decisions of jurisdictions (as in Israel, the Russian Federation, Finland ${ }^{12 ; 13}$ ) and enforcement agencies with their responsibility to the Ministry of Justice until recently took place in Ukraine. The advantage of this approach is, first of all, includes the discharge of the Ministry of Justice from the rather current issues of enforcement of court decisions and punishments, focusing its activities on general leadership, direction, coordination and control of activities in these areas. The obvious disadvantages include the need for the formation and maintenance of additional management apparatus both nationally and locally. That is why in Ukraine, as in Belarus and Kazakhstan offices and departments of enforcement are separated structural units of the Ministry of Justice and its territorial bodies. In some foreign countries, in particular in Germany, the enforcement authorities may also be subordinated to the court power ${ }^{14}$. Although regardless of the status of enforcement agencies, they always are closely associated with the courts, for example, in the US, the Marshals Service operates under Department of Justice, while functionally focusing on organizational ensuring the activity of the courts and the execution of orders, and procedural decisions of judges. In addition, we believe that given the specific nature of the activities of the authorities the execution of sentences related to the detention of prisoners, their imprisonment, they may be re-socialized and prevented from committing new crimes justifying their allocation to a separate central executive authority or inclusion in the structure of the Ministry of Internal Affairs (as in Belarus and Kazakhstan).

12 Чумак О. О. Практика організації діяльності органів примусового виконання рішень іноземних держав. Форум права. 2011. № 4. C. 814, 815. URL: http://nbuv.gov.ua/j-pdf/FP_ index.htm_2011_4_133.pdf (дата звернення: 21.12.2016).

${ }^{13}$ Сазанов С. В., Могилёва И. Ю. Организация структуры органов принудительного исполнения Финляндской Республики. Юридический мир. 2010. № 5. С. 37-39.

${ }^{14}$ Чумак О. О. Практика організації діяльності органів примусового виконання рішень іноземних держав. Форум права. 2011. № 4. C. 815. URL: http://nbuv.gov.ua/j-pdf/FP_ index.htm_2011_4_133.pdf (дата звернення: 21.12.2016). 
At the same time, the a subordination of the prison system to the Ministry of Justice is a fairly widespread worldwide practice that has been successfully applied, for example, to Austria, Denmark, Poland, USA, France, Czech Republic, Japan and other foreign countries, but it is more about coordination and direction the prison service by the Justice Department, rather than its full integration into the Ministry of Justice.

The Ministry of Justice of the Republic of Moldova does not have its own territorial bodies, which is primarily explained by the relatively small territory of the country and the size of its population. Against this background, something unclear is as for emerging functioning of subordinates to the Ministry of Justice of the Registry and The State Registration Chamber, whose integration into the Ministry of Justice would facilitate the management mechanism and organization of their work. Other bodies that do not subordinate, but only dependent on the Ministry of Justice of the Republic Moldova, are the Department of Prisons, National Inspectorate for Probation and the Agency for the Administration of Courts. In this case, the separated status of the first two bodies, as already indicated, is peculiar by the nature of their activities in organizing the execution of sentences. Like deprivation of Ministry of Justice of Ukraine of powers in the field of judicial administration, so the separation from the Ministry of Justice of Moldova of the Agency for Administration of courts (which provides for the organizational activity of the courts) is quite logically aims at ensuring the independence of the judiciary in the administration of justice.

Within the framework of decentralization, demonopolization and democratization of the state administration in Ukraine there is also an interesting model of decentralized administration in the field of justice in the United States of America, which is manifested in non-proliferation activities of the federal Department of Justice at the state and county levels, as well as at the formation in the states of their own governing bodies in the field of justice. For comparison, The Federal Republic of Germany, as I.I. Mikultsya ${ }^{15}$, accents, the main part of managerial functions (eg prosecutors and executions) relies on the land ministries of justice, but under the control of the federal minister.

In the US, this is primarily determined by the depth of state federalization, particularism of law and separation of the judicial system of the state from the federal judicial system. However, as R.V. Budetskyy points out, Federal US Justice Department and its subordinate bodies are

\footnotetext{
${ }^{15}$ Микульця І. І. Адміністративно-правовий статус органів юстиції України: дис. ... канд. юрид. наук: 12.00.07. Харків, 2014. С. 160.
} 
not legally guaranteed mechanisms for influencing state ${ }^{16}$ authorities, in particular by issuing appropriate ones mandatory for enforcement, control and enforcement penalties in case of violation of such acts.

The selection by H.I. Kobatskaya ${ }^{17}$ of law enforcement (the Ministry of Justice focuses on the judiciary and law enforcement) and general law (limited impact on the judiciary; law enforcement system and concentration on issues of organization, security, control and provision of services in various spheres of social life) types of bodies of Justice deserves attention. According to this approach, the law enforcement type is widespread in the world, the judiciary, though, given the tasks and powers of the judiciary of Ukraine and several other post-Soviet countries, can be attributed exactly to common law type.

It should be emphasized that the activity of the Ministry of Justice is just like any other activity of a governmental body in both Ukraine and foreign countries is closely linked to human rights - by ensuring their proper implementation (for example, the right to legalize non-profit organization), as well as by creating the conditions for compliance, implementation and protection of human rights by other entities (legal executives, notaries, lawyers, court experts, etc.). As for us, the direction of activity of bodies of justice for the realization and protection of the rights and interests of citizens (as well as legal entities and the state) should be determined not so much by the specific task (direction of work), but by one of the key principles of their organization and activity. Human rights, public and state interests should be a common guideline for all aspects of the functioning of justice, while (at least in the post-Soviet countries) specific human rights activities are being carried out by more of their subordinate bodies.

In some foreign countries, registration by the justice authorities of regulatory acts of the government authority is an effective preventive instrument of control over the legitimacy of their rulemaking - both in terms of content and order of the adoption of such acts. By the way, a kind of analogue of the mechanism of registration of legal acts also exists in Germany, where the Ministry of Justice checks compliance with legal techniques and conformity of draft acts of federal ministries and

${ }^{16}$ Будецький Р. Особливості управління юстицією у Сполучених Штатах Америки: організаційно-правовий аспект. Вісник Національної академії правових наук Украӥни. 2014. № 3. C. 162.

${ }^{17}$ Кобацька Х. І. Порівняльно-правова характеристика центральних органів виконавчої влади у сфері юстиції: європейська традиція та вітчизняна практика: автореф. дис. ... канд. юрид. наук: 12.00.01. Київ, 2017. С. 14. 
intergovernmental agreements with national and international law ${ }^{18}$. Registration efficiency of regulations and legal acts is mandatory for entry into force of the acts, and it is also conditioned, for example, by the right of bodies of Justice to submit preference as for violation remedy and to make a motion as for bringing the perpetrators to disciplinary responsibility (Belarus, Kazakhstan). Herewith, like in Ukraine, in the Republic of Moldova, the judicial authorities exercise legal review and registration of acts concerning the rights and legitimate interests of citizens (Resolution of the Government of Moldova dated 03.10.2012 No. $736^{19}$ ).

In European and other foreign countries, it is quite common to charge justice authorities with some functions in the field of judicial administration (first of all, formation of the judicial establishment, the supervision of the work of the courts, the provision of their activities). So, for example, the Ministry of Justice of Germany is directly responsible for the course of justice and oversees the activities of federal courts, takes participation in the preparation of elections to high courts, organizationally and otherwise ensures their functioning ${ }^{20}$. In Belarus, according to Art. 183 of the Judiciary Code and the status of judges of 29.06.2006 No. $139-\mathrm{C}^{21}$ the justice authorities exercise organizational and logistical support of regional, district (city), specialized and military courts, as well as the selection and training of candidates for a judge position (especially the latter being a potential lever to influence judges). In countries of Muslim law, as noted by A.V. Fedkovych ${ }^{22}$, the institutions of justice are also actively involved in the formation of the Judicial establishments and are responsible for organization and operation of the justice system.

The justice authorities in foreign countries as a continuation of their competence in the field of justice may also be entrusted with the power to implement public policy on forensic examination. Such activity is only indirectly relevant to the courts and may be exercised by the judicial

18 Aufgaben und Organisation Ministerium/Das Bundesministerium der Justiz und für Verbraucherschutz. URL: http://www.bmjv.de/DE/Ministerium/AufgabenOrganisation/Aufgaben Organisation_node.html (дата звернення: 17.12.2016).

19 Об организации и функционировании Министерства юстиции: постановление Правительства Республики Молдова от 03.10.2012 № 736. Monitorul Oficial. 2012. №. 212-215. Ст. 799.

20 Aufgaben und Organisation Ministerium/Das Bundesministerium der Justiz und für Verbraucherschutz. URL: http://www.bmjv.de/DE/Ministerium/AufgabenOrganisation/Aufgaben Organisation_node.html (дата звернення: 17.12.2016).

${ }^{21}$ О судоустройстве и статусе судей: кодекс Республики Беларусь от 29.06.2006 № 139-3. Национальный реестр правовых актов Республики Беларусь. 2006. № 107. Ст. 2/1236.

${ }^{22}$ Федькович О. В. Роль органів юстиції в організації та забезпеченні функціонування системи правосуддя: автореф. дис. ... канд. юрид. наук: 12.00.10. Київ, 2007. 19 с. 
authorities irrespective of their judicial administration functions (such as in Ukraine and Kazakhstan, for example). Authority of bodies of forensic justice does not involve direct interference with professional activity of forensic experts, mainly manifesting itself according to Law of Kazakhstan dated 18.03.2002 No. 304- $\mathrm{II}^{23}$ in organization and material and technical support of forensic institutions and licensing of forensic experts. These forensic institutions, without exercising state power authority, are not separate bodies of justice but they are also under the responsibility of the relevant ministry of Justice, for example, the National Center for Forensics at the Ministry of Justice of Moldova. At the same time, the experience of the Republic of Belarus, forensic experts, is quite interesting institutions (including those operating within the Ministry of Justice system) were merged into Independent State Committee of Forensic Expertise (Presidential Decree of Belarus of 04/22/2013, No. 202 ${ }^{24}$ ). As for us, in Ukraine there is a similar grouping under the auspices of different ministries of forensic institutions can facilitate the streamlining of their status and activities, regardless of their subordination to the Ministry justice or self-status.

A modern and progressive line of activity of the justice authorities is organization of providing legal assistance to citizens aimed at creating conditions for the proper exercise and protection of their rights and legitimate interests, security accessibility of legal services and raising public awareness.

Providing legal assistance and compensation for victims of crime, as O.V. Fedkovich ${ }^{25}$ states, is a fairly common task today for the authorities of justice in many European countries of the Romano-German legal family (for example, in Poland).

The common feature of the status of justice bodies in foreign countries is their uniqueness, which is, first and foremost, in the sole control of their system by the Minister of Justice. Therefore, the important role in organizing the activities of the justice authorities plays the subordination as well as the order of appointment and dismissal of the minister Justice. Usually in foreign countries, depending on the form of government, the Minister of Justice reports to the head of government and/or the head

\footnotetext{
${ }^{23}$ Об органах юстиции: закон Республики Казахстан от 18.03.2002 № 304-II. Ведомости Парламента Республики Казахстан. 2002. № 6. Ст. 67.

24 Об образовании Государственного комитета судебных экспертиз Республики Беларусь: указ Президента Республики Беларусь от 22.04.2013 № 202. Национальный реестр правовых актов Республики Беларусь. 2013. Ст. 1/14233.

${ }^{25}$ Федькович О. В. Роль органів юстиції в організації та забезпеченні функціонування системи правосуддя: автореф. дис. ... канд. юрид. наук: 12.00.10. Київ, 2007. 19 с.
} 
of state. The sole appointment and dismissal of the Minister of Justice (as in Belarus and Kazakhstan) in fact leads to his dependence on the Head of State. In our view, it is more constructive and democratic to involve in the order of appointment and dismissal of the Minister of Justice various higher bodies of state power, which will contribute not only to the balance of branches of government, but also to strengthening the independence of the Ministry of Justice and at the same time control over its activity to different entities. Considering the above, in the conditions of the parliamentary-presidential form of government, it is optimal to preserve the existing subordination of the system of justice bodies to the government and the procedure for appointing the Minister of Justice of Ukraine the parliament upon the submission of the Prime Minister.

The Institution of the Minister of Justice in foreign countries has a number of common features, which is manifested in the exercise of the traditional general powers to lead the work of the relevant ministry and other justice bodies, namely the organization of work, the division of responsibilities among subordinates, the definition of work plans, approval of provisions on structural units, issuance of mandatory orders, suspension and/or cancellation of decisions of subordinate bodies and units, etc.

In foreign countries, the system of justice, as a rule, is represented by the Ministry of Justice, its territorial bodies and other subordinate specialized bodies, whose activities are usually aimed at implementing state legal policy, improving the legislation, ensuring the functioning of the judicial system, enforcement of decisions of jurisdictions, administration and judiciary States in the courts, the organization of a practice of law and a notary.

The organization of the activity of justice bodies in foreign countries reveals, due to peculiarities of the state system, legal customs and other factors, significant differences in terms of the specific composition of the system of justice bodies and the degree of their independence, subordination to the Ministry of Justice of courts and prosecutor's offices, scope of tasks, forms of tasks, the Minister of Justice status, etc. The use of foreign experience in Ukraine is of primary importance for further decentralization of the activity of the bodies of justice, reduction of their administrative personnel and staff, streamlining the status of units of the state executive service and execution of criminal penalties, extension of powers to register legal acts and control their legal assistance, intensification of legal assistance and legal education of the population. 


\section{Ways of development of the administrative legislation that regulates the activity of the justice bodies of Ukraine}

The need for the development of the institute of justice is conditioned by the general processes of Ukraine's European integration, democratization and decentralization of public administration. It should be noted that some aspects of the improvement of the administrative and legal status of the bodies of justice of Ukraine have already been considered by such scientists as N.A. Zheleznyak, Kh.I. Kobotska (Dutka), I.I. Mykultsya, M.M. Priydak, S.R. Stanik, B.S. Stichinsky and others. At the same time, their scientific works have now partially lost their relevance, and they contain only some specific proposals for the development of the justice system of Ukraine, without reflecting a comprehensive approach to improving the administrative and legal regulation of their organization and activities of the current state bodies, legal and social-political realities of Ukraine. Therefore, in the context of increasing the efficiency and effectiveness of the functioning of the bodies of justice of Ukraine, the issues of improving the administrative and legal principles of their activity are also considered relevant.

First of all, it should be noted that the real improvement of the legal foundations of the organization and activity of the justice bodies of Ukraine should include not only the adoption of new and amendments to the current regulatory legal acts, but also the proper scientific and theoretical substantiation of the relevant elements of the administrative and legal status of the justice bodies. In addition, the directions and ways of improving the activities of the justice authorities should be determined solely on the basis of the urgent needs of the administration in the field of justice and within the general course of the internal policy of the state, while taking into account the existing organizational, human and material resources, peculiarities of the state system and the legal system of Ukraine, as well as positive foreign experience of functioning of justice bodies. An integral part of the process of improving the status of the justice bodies of Ukraine should be not only updating the administrative and legal bases, but also ensuring their practical implementation, real compliance and implementation in the activity of the justice bodies ${ }^{26}$.

The complexity, validity and consistency of improvement of the Institute of Justice of Ukraine are directly related to the preparation and approval at the government level of the relevant Concept of development

${ }^{26}$ Предместніков О. Г. Пріоритетні напрями подальшого вдосконалення державного управління під час проведення адміністративної реформи в Україні. Правові новели. 2014. № 1. C. 49-54. 
of the system of justice of Ukraine. Substantially, the Concept should clearly define not only the general goals and vectors of reform of the justice bodies of Ukraine, but also all the necessary legislative and organizational measures to improve their organization and activities, the timeframe for implementation of such measures and responsible bodies/persons.

A similar proposal was made by N.A. Zheleznyak on the advisability of adopting the Justice Reform Concept, in particular as part of the State Legal Policy Concept, the Judicial Reform Concept, or the Administrative Reform Concept $^{27,28}$. As for us, the Concept of development of the system of justice bodies, as one of the basic subsystems of public authorities in Ukraine, should be a separate comprehensive, professional and specific document, which at the same time will be consistent with all other concepts, programs and plans for the development of society, the state and law.

As a key measure to improve the administrative and legal foundations of the functioning of the justice system of Ukraine and to ensure greater legality and efficiency of their activity, we consider increasing the level of legislative regulation of their status and streamlining by-laws on the functioning of the justice bodies.

Increasing the level of legislative regulation of the status of the justice bodies of Ukraine necessitates the revision and streamlining of the existing array of by-laws and regulations concerning the justice bodies. Constructive is also an amalgamation of by-laws regulating various aspects of one line of activity of the justice bodies of Ukraine. The same applies to the by-laws that regulate the substantially homogeneous activity of the justice bodies in their various areas of competence. Optimization of the by-law regulation of the status of justice bodies of Ukraine will facilitate simplification and streamlining of their activity, provide integrity and accuracy of regulation will identify and eliminate legal conflicts, loopholes and duplicate rules.

A key measure of development of the bodies of Institute of Justice of Ukraine is a clear legal definition of the status and composition of their system, which will reflect a specific approach to understanding their nature and essence. One of the starting points of the status of the bodies of justice of Ukraine is their separation from the judiciary and the prosecutor's

27 Железняк Н. А. Правові та організаційні форми діяльності Міністерства юстиції України у здійсненні державної правової політики (теоретичні та практичні питання): дис. ... канд. юрид. наук: 12.00.07. Київ, 2004. С. 170, 171.

${ }^{28}$ Железняк Н. А. Реформування органів юстиції в контексті реалізації державної правової політики та проведення адміністративної реформи в Україні. Наукові записки НаУKMA. 2003. Т. 22. Ч. 2. C. 226-230. 
office. Notaries, lawyers, court experts, arbitration managers, as well as any other subordinate officials, enterprises, institutions and organizations cannot be designated as bodies of justice, since they do not directly exercise state-power organizational and administrative powers in the field of justice.

Only the Ministry of Justice of Ukraine and its territorial bodies should be included in the system of justice bodies of Ukraine. At the same time, it should be emphasized that the central bodies of executive power, whose activities are directed and coordinated by the Minister of Justice of Ukraine, are not themselves bodies of justice, in particular, this concerns the State Archival Service of Ukraine, whose activity according to the Decree of the Cabinet of Ministers of Ukraine dated 21.10.2015 No. $870^{29}$ is not fulfilled in the field of justice, but in the field of archival affairs and record keeping.

Improving the status of the main territorial administrations of justice should, as a matter of priority, involve streamlining their relations with local state administrations, in particular with regard to settling the principles of joint activity and law-making, forms and content of coordination and control by heads of local state administrations, as well as approving their plans of work of the main territorial administrations. We should also note the need to eliminate the gaps in the regulation of the status of the Main Territorial Administration of Justice in the city of Sevastopol, in the absence of the relevant Law of Ukraine on the status of this city.

At the same time, in order to observe and protect the rights of citizens, a more detailed legislative regulation of the peculiarities of the status and rules of work of territorial bodies of the Ministry of Justice of Ukraine in connection with the temporary occupation of the territory of the Autonomous Republic of Crimea and the city of Sevastopol and the conduct of anti-terrorist operations in some areas of Donetsk and Luhansk regions is more relevant.

Administrative and legal regulation of the activity of the bodies of justice of Ukraine should include the consolidation of their status as a whole and separate subsystem of bodies of executive power (state administration), characterized by subordination of the government, common purpose of activity, hierarchy and centrality in relation to the Ministry of Justice of Ukraine. The Ministry of Justice of Ukraine, being the leading central body of executive power on issues of implementation

29 Про затвердження Положення про Державну архівну службу України: постанова Кабінету Міністрів України від 21.10.2015 № 870. Офіиійний вісник України. 2015. № 88. Ст. 2930. 
and ensuring the formation of state legal policy, is the governing body of the system of justice bodies. At the same time, if the given status of the Ministry of Justice of Ukraine is somehow reflected in normative legal acts, the status of its territorial bodies in the system of bodies of executive power is not clearly stated. In this regard, we propose to define the territorial bodies of the Ministry of Justice of Ukraine as the leading local executive authorities on the implementation of relevant state policy.

The legal definition of the purpose of the activity of the bodies of justice is crucial not only for a proper understanding of their nature and vectors of development, but also for ensuring the purposefulness of the activity of the bodies of justice, and full consistency of their purpose, tasks, functions and powers. The current administrative and legal principles of the activity of the bodies of justice of Ukraine do not substantially fix the principles of their functioning, which can only be indirectly established on the basis of the general legislation on the status of executive bodies and other state bodies. We must disagree with this approach, since the principles embody conceptual frameworks that reflect the leading political and legal ideas and values regarding the nature and rules of the organization and operation of justice bodies. A clear formulation and real implementation of the principles is a necessary prerequisite for the legitimate and effective operation of the justice authorities, their rational organization, stability and consistency of the institution building in Ukraine. Among the basic principles that should not just be listed in the relevant law on the organs of justice, but really be embodied in its provisions, first of all, are the principles of the rule of law (including the law and respect for the rights and interests of citizens, legal persons, society and state), political, religious and other impartiality, professionalism, service to the Ukrainian people, continuity, transparency, accountability, responsibility, interaction, unity, systematic and others.

It should be noted that the improvement of the activity of the justice bodies of Ukraine in the current realities should largely involve bringing their tasks and powers in line with the actual needs of modernization, democratization, liberalization, decentralization and simplification of administration in the field of justice, introduction of a positive European experience. A comprehensive legislative regulation of the powers of the justice authorities will ensure the stability of their competence and impede the exercise of their non-judicial powers; grouping of specific powers according to the directions of activity of justice bodies will express conformity of their tasks and powers; securing the powers of the justice authorities in their specific units will ensure consistency of competence 
and structure; and the systematic nature of the Ukrainian justice authorities must be based on the full consistency of the competence of the Ministry of Justice of Ukraine and its territorial bodies.

At the level with the purpose of activity, tasks and powers, an integral element of the status of the bodies of justice of Ukraine are their functions, which at the same time remain normatively unregulated. The precise legal definition of the functions of the bodies of justice, their separation from the tasks and ensuring consistency with the powers is a necessary prerequisite for the integrity of the status and orderliness of the activity of the justice bodies of Ukraine. Among the main functions of the bodies of justice can be distinguished rulemaking, control, constituent, law enforcement, organizational, managerial and coordination, registration, representative, analytical and other functions.

The leading task of the Ministry of Justice of Ukraine is to ensure the formation and implementation of state legal policy, which is directly related to the development of the legal system of Ukraine, improving the rulemaking of public authorities, updating and eliminating shortcomings of national legislation. In this regard, in the framework of ensuring successful European integration of Ukraine, we consider it possible and expedient to actively involve the Ministry of Justice of Ukraine to work on the adaptation of the legislation of Ukraine to the EU legislation, for example, to carry out (previously carried out) examination of draft regulatory acts for their compliance with the acquis communautaire. Ch.I. Kobatska brings attention to the appropriateness of intensifying the participation of the Ministry of Justice of Ukraine in the implementation of Ukraine's European integration policy ${ }^{30}$.

The more effective implementation of the state legal policy by the bodies of justice, the coherence and improvement of the quality and legality of the rulemaking, as well as the observance of the rights and interests of citizens will be facilitated by the extension of the powers of the state registration justice to all normative legal acts of the state authorities and local self-government bodies; carrying out legal expertise on not only drafts of relevant legal acts, but also existing acts with the right to initiate their amendment and/or cancellation; compulsory examination by the Ministry of Justice of Ukraine of draft laws concerning its subjects; intensification of control of rulemaking of other executive bodies, etc.

\footnotetext{
${ }^{30}$ Кобацька Х. І. Порівняльно-правова характеристика центральних органів виконавчої влади у сфері юстиції: європейська традиція та вітчизняна практика: автореф. дис. ... канд. юрид. наук: 12.00.01. Київ, 2017. С. 4.
} 
The implementation of various specialized legal examinations by the justice authorities (legal examination within the framework of state registration of acts, gender-legal and anti-corruption expertise, etc.) determines a large number of unregulated by-laws. Therefore, in order to eliminate duplication, gaps and disagreements in regulating the procedure for conducting relevant legal expertise by the bodies of justice, it is first of all necessary to establish a single comprehensive regulation of the procedure and timing of initiation and conduct of legal expertise, as well as its clear legal consequences. In addition, the current powers of the Ministry of Justice of Ukraine to conduct legal expertise should be aligned with the regulatory procedures for the preparation, review and adoption of laws of Ukraine and acts of the Verkhovna Rada of the Autonomous Republic of Crimea.

To date, a large part of the powers of the justice bodies in the field of state registration have been delegated to local governments and notaries, which not only significantly relieves the activity of the justice bodies of Ukraine, but also provides accessibility for citizens of the relevant administrative services. R.V. Budetskyy ${ }^{31}$ also agrees with the decentralization of the administration of justice and emphasizes the need to delegate some of the managerial powers to the local authorities and nongovernmental entities. For this reason, in order to ensure the legal and proper fulfillment of such registration powers, the activities of the justice authorities should focus on continuous thorough monitoring of the work of state registration entities, their accreditation and the provision of comprehensive methodological assistance, and ensuring the high professional level of state registrars. Improving the activities of the justice sector in the field of justice should also include continuing the current practice of simplifying and speeding up state registration procedures (such as marriage) and the development of relevant electronic services ("Online House of Justice").

Participation in the legal education of the population is a promising area of improvement of the activity of justice bodies. Overcoming formalism (first of all by specifying powers and strengthening the control of their enforcement) and intensifying the comprehensive implementation by law enforcement agencies of various real and effective law enforcement measures (including via the Internet, television, radio, periodicals, public events, etc.) contribute to the development of Ukraine's civil society,

\footnotetext{
${ }^{31}$ Будецький Р. В. Міністерство юстиції України: до проблеми визначення адміністративно-правового статусу. Юрист України. 2014. № 3. С. 33, 34.
} 
raising the level of citizens' legal culture, implementation and protection of their rights.

At the same time, the activity of justice bodies in the field of providing free legal aid is also of great importance, which creates (in particular by setting up appropriate centers and bureaus on the basis of liquidated district justice bodies) conditions for the provision of accessible legal services aimed at ensuring the realization of citizens' rights and their protection and recovery. At present, the competence of the Ministry of Justice of Ukraine in this area is determined only in general terms, and therefore, given the status of justice bodies as leading subjects of the implementation of state legal policy, it is appropriate to consider a complex assignment of normative, coordinating, organizational and other powers in the sphere of providing free of charge legal assistance. The current solution in this area requires the provision of branch offices and free legal aid centers and bureaus, as well as staffing them with really qualified staff, involving highly-qualified lawyers to provide legal aid.

The structural organization and competence of the Ukrainian justice authorities must also be consistent with the number of their staff. As we have already noted, in the context of the elimination of district level justice bodies and integration into the system of justice units of state registration units, state executive service and execution of criminal penalties and probation, the staffing of justice bodies generally corresponds to the scope of their powers and number of subdivisions. At the same time, taking into account foreign experience and in order to save state funding, it is possible to further systematically reduce the number of employees of justice by eliminating duplicate units, redistribution of powers and staff, reducing the administrative apparatus, stimulating and improving the efficiency of employees. Another aspect of improving the activity of the justice bodies is the need to ensure a high professional level of their employees, effective counteraction to corruption and overcoming the problem of significant staff turnover, which among other things requires the enhancement of the authority of the justice bodies, increasing their legal and social guarantees of their employees. In order to overcome staff turnover in the bodies of justice I.I. Mykultsya ${ }^{32}$ also draws attention to the need to provide mentoring for newly recruited employees, to balance the workload for each employee, to increase the requirements for their work, bonuses depending on the performance indicators, proper equipment of the workplace, ensuring a healthy microclimate in the team, etc.

\footnotetext{
${ }^{32}$ Микульця I. І. Адміністративно-правовий статус органів юстиції України: дис. ... канд. юрид. наук: 12.00.07. Харків, 2014. С. 167.
} 
Thus, the improvement of administrative and legal foundations of the activity of the bodies of justice of Ukraine should have a proper scientific and theoretical substantiation, be all-embracing, comprehensive and consistent, providing for the constitutional consolidation of the status of the bodies of justice of Ukraine, adoption of a profile detailed Law of Ukraine, updating of other legislative acts, coordination and harmonization of legal acts on the issues of organization and activity of the justice bodies of Ukraine, ensuring real compliance and enforcement in their activities and applicable law.

\section{CONCLUSIONS}

The bodies of justice are indispensable components of the state apparatus of each state, which are responsible for the formulation and implementation of its legal policy, the establishment of the rule of law, and for the proper functioning of the jurisdictions and related entities. Despite the common purpose of their activities, the status, composition, competence and organization of the activities of justice bodies in different countries differ significantly, that is conditioned by the peculiarities of their legal system, constitutional order, legal traditions and the state of social development.

Improvement of the administrative and legal foundations of the activity of the bodies of justice of Ukraine should have proper scientific and theoretical substantiation, be comprehensive, all-embracing and consistent, carried out on the basis of urgent needs of management in the field of justice, within the course of the state domestic policy and taking into account the available organizational and financial resources, especially the state system and legal system of Ukraine, as well as positive foreign experience. The key vectors for the development of the justice bodies of Ukraine should be optimization and simplification of their organization, reduction of the administrative apparatus and staff, streamlining of the status of the units of the state executive service and execution of criminal penalties, application of modern progressive approaches to the fulfillment of tasks, decentralization of activities and ensuring priority in its observance and implementation of rights of citizens.

The updating of the legal bases for the organization and activity of the justice bodies of Ukraine is first and foremost related to the preparation and approval by the Government of the Concept of development of the justice bodies of Ukraine. The development of administrative and legal regulation of the activity of the bodies of justice of Ukraine requires the constitutional consolidation of the status of the bodies of justice of 
Ukraine, improvement of legislative acts, approval of the Regulations of activity of the bodies of justice and unified Regulations on their subdivisions, intensification of interagency regulation, harmonization and regulation of subordinate legal acts bodies of justice of Ukraine. An integral part of such improvement should be not only the updating of administrative and legal bases, but also ensuring their practical implementation, actual adherence and implementation in the activity of the justice bodies of Ukraine.

\section{SUMMARY}

It is stated that effective implementation of legal and non-legal forms of activity of the bodies of justice of Ukraine depends on the delimitation and coherence of legal and non-legal forms of activity, simplification of unreasonably complicated procedure of implementation of certain legal forms of activity, prevention of formalism in the implementation of forms of activity, ensuring compliance of the legal consequences of the actions of the justice bodies of Ukraine with their tasks and powers.

It is established that in foreign countries the system of justice bodies, as a rule, consists of the Ministry of Justice, its territorial bodies and other subordinate bodies, whose activity is aimed at the implementation of state legal policy, improvement of legislation, ensuring the functioning of the judicial system, enforcement of judgments and penalties, representation of the state in the courts, organization of a legal practice and a notary public.

It is determined that the organization of justice bodies in foreign countries reveals significant differences in terms of the composition of the system of justice bodies and their degree of independence, accountability to the Ministry of Justice of courts and prosecutors, their scope of tasks, and the extent of their tasks, the status of the Minister of Justice, etc. In foreign countries, the judicial and law enforcement type of justice system has become widespread, while in Ukraine and in a number of other postSoviet countries, justice bodies are of the general law type.

Attention is drawn to the fact that the development of administrative legislation governing the activity of the justice authorities of Ukraine should be purposeful, comprehensive and scientifically substantiated, taking into account the current needs of the administration in the field of justice and positive experience of foreign countries. 


\section{REFERENCES}

1. Будецький Р. В. Міністерство юстиції України: до проблеми визначення адміністративно-правового статусу. Юрист України. 2014. № 3. С. 29-36.

2. Будецький Р. Особливості управління юстицією у Сполучених Штатах Америки: організаційно-правовий аспект. Вісник Національної академї правових наук України. 2014. № 3. С. 155-164.

3. Железняк Н. А. Реформування органів юстиції в контексті реалізації державної правової політики та проведення адміністративної реформи в Україні. Наукові записки НаУКМА. 2003. T. 22. Ч. 2. С. 226-230.

4. Железняк Н. А. Правові та організаційні форми діяльності Міністерства юстиції України у здійсненні державної правової політики (теоретичні та практичні питання): дис. ... канд. юрид. наук: 12.00.07. Київ, 2004. 258 с.

5. Кобацька X. I. Порівняльно-правова характеристика центральних органів виконавчої влади у сфері юстиції: європейська традиція та вітчизняна практика: автореф. дис. ... канд. юрид. наук: 12.00.01. Київ, 2017. 19 с.

6. Микульця I. I. Адміністративно-правовий статус органів юстиції України: дис. ... канд. юрид. наук: 12.00.07. Харків, 2014. 203 с.

7. О судоустройстве и статусе судей: кодекс Республики Беларусь от 29.06.2006 №139-3. Начиональный реестр правовых актов Республики Беларусь. 2006. № 107. Ст. 2/1236.

8. Об образовании Государственного комитета судебных экспертиз Республики Беларусь: указ Президента Республики Беларусь от 22.04.2013 № 202. Национальный реестр правовых актов Республики Беларусь. 2013. Ст. 1/14233.

9. Об органах юстиции: закон Республики Казахстан от 18.03.2002 № 304-II. Ведомости Парламента Республики Казахстан. 2002. № 6. Ст. 67.

10.Об организации и функционировании Министерства юстиции: постановление Правительства Республики Молдова от 03.10.2012 № 736. Monitorul Oficial. 2012. №. 212-215. Ст. 799.

11.Об утверждении Положения о Министерстве юстиции Республики Беларусь: постановление Совета Министров Республики Беларусь от 31.10.2001 № 1605. Национальный реестр правовых актов Республики Беларусь.2001. № 107. Ст. 5/9385.

12.Положение о главном управлении юстиции Минского областного исполнительного комитета: решение Минского 
областного исполнительного комитета от 09.03.2015 № 199/Минский областной исполнительный комітет. URL: http://minobljust.gov.by/ ru/polojenie (дата звернення: 17.12.2016).

13. Предместніков О. Г. Пріоритетні напрями подальшого вдосконалення державного управління під час проведення адміністративної реформи в Україні. Правові новели. 2014. № 1. С. 49-54.

14.Про затвердження Положення про Державну архівну службу України: постанова Кабінету Міністрів України від 21.10.2015 № 870. Офіиійний вісник України. 2015. № 88. Ст. 2930.

15. Сазанов С. В., Могилёва И. Ю. Организация структуры органов принудительного исполнения Финляндской Республики. Юридический мир. 2010. № 5. С. 37-39.

16. Структура главного управления юстиции Минского областного исполнительного комитета: распоряжение председателя Минского областного испонительного комитета от 25.04.2013 № 90p / Минский областной исполнительный комитет. URL: http://minobljust.gov.by/ dadvfiles/000127_682722_struktura_gyu.doc (дата звернення: 17.12.2016).

17. Федькович О. В. Роль органів юстиції в організації та забезпеченні функціонування системи правосуддя: автореф. дис. ... канд. юрид. наук: 12.00.10. Київ, 2007. 19 с.

18. Чумак О. О. Практика організації діяльності органів примусового виконання рішень іноземних держав. Форум права. 2011. № 4. C. 814, 815. URL: http://nbuv.gov.ua/j-pdf/FP_index.htm_ 2011_4_133.pdf (дата звернення: 21.12.2016).

19. Aufgaben und Organisation Ministerium / Das Bundesministerium der Justiz und für Verbraucherschutz. URL: http://www.bmjv.de/DE/ Ministerium/Aufgaben Organisation/AufgabenOrganisation_node.html (дата звернення: 17.12.2016).

20. Organisation / Die Österreichische Justiz. URL: https://www.justiz.gv.at/web2013/home/ministerium/organisation 8ab4a8 a422985de30122a91a6504629f.de.html (дата звернення: 18.12.2016).

\section{Information about the author: Predmestnikov O. H.,}

Doctor of Law Sciences, Associate Professor, Professor at the Department of Professional and Special Disciplines, Kherson Faculty of Odessa State University of Internal Affairs 1, Fonvizina str., Kherson, 73000, Ukraine 


\section{NOTES}

206 
NOTES 
Publishing house "Liha-Pres"

9 Kastelivka str., Lviv, 79012, Ukraine

44 Lubicka str., Toruń, 87-100, Poland

Printed by the publishing house "Liha-Pres"

Passed for printing: October 15, 2019.

A run of 150 copies. 